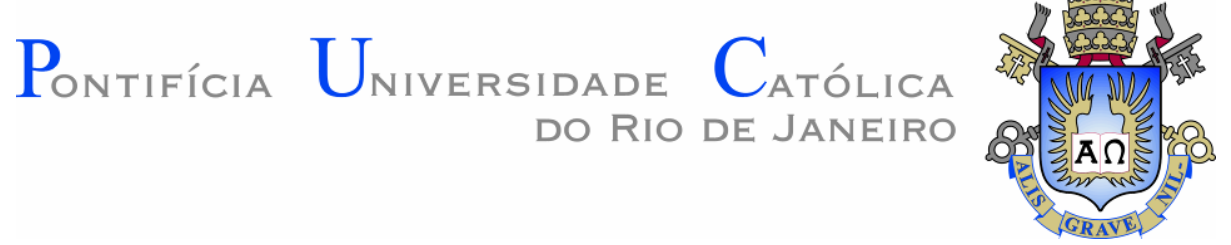

Pedro Pinheiro Teixeira

\title{
ENSINO DE EVOLUÇÃO E RELIGIOSIDADE $O$ caso de duas escolas estaduais do Rio de Janeiro
}

\section{Tese de Doutorado}

Tese apresentada como requisito parcial para obtenção do grau de Doutor pelo Programa de Pós-graduação em Educação do Departamento de Educação do Centro de Teologia e Ciências Humanas da PUC-Rio.

Orientador: Prof. Marcelo Andrade Co-orientador: Prof. Ralph Levinson 
Pedro Pinheiro Teixeira

"Ensino de evolução e religiosidade: o caso de duas escolas estaduais do Rio de Janeiro."

Tese apresentada como requisito parcial para obtenção do grau de Doutor pelo Programa de Pós-graduação em Educação do Departamento de Educação do Centro de Teologia e Ciências Humanas da PUC-Rio. Aprovada pela Comissão Examinadora abaixo assinada.

Prof. Marcelo Andrade

Orientador

Departamento de Educação - PUC-Rio

Prof. Ralph Levinson

Co-orientador

Institute of Education - University College London

Profa. Cynthia Paes de Carvalho

Departamento de Educação - PUC-Rio

Prof. Alberto José da Costa Tornaghi

Departamento de Educação - PUC-Rio

Prof $^{a}$ Sandra Lucia Escovedo Selles

UFF

Prof. Luís Fernando Marques Dorvillé UERJ

Profa Denise Berruezo Portinari Coordenadora Setorial do Centro de

Teologia e Ciências Humanas PUC-Rio

Rio de Janeiro, 
Todos os direitos reservados. É proibida a reprodução total ou parcial do trabalho sem autorização da universidade, do autor e do orientador.

\section{Pedro Pinheiro Teixeira}

Graduou-se em Licenciatura em Ciências Biológicas na UFRJ (Universidade Federal do Rio de Janeiro) em 2009. É mestre em Educação pela PUC-Rio (2012). Realizou estágio de doutorado sanduíche no Institute of Education da University College London, no Reino Unido. Participou de diversos congressos e possui publicações na área de Educação e Ensino de Ciências. É professor de Biologia e Ciências na Educação Básica e integrante do Grupo de Estudos sobre Cotidiano Escolar e Culturas (GECEC).

Ficha Catalográfica

Teixeira, Pedro Pinheiro

Ensino de evolução e religiosidade : o caso de duas escolas estaduais do Rio de Janeiro / Pedro Pinheiro Teixeira ; orientador: Marcelo Andrade ; coorientador: Ralph Levinson. - 2016.

280 f. : il.(color.) ; $30 \mathrm{~cm}$

Tese (doutorado)-Pontifícia Universidade Católica do Rio de Janeiro, Departamento de Educação, 2016.

Inclui bibliografia

CDD: 370 


\section{Agradecimentos}

A todos os membros da banca avaliadora, por aceitarem o convite, pela disposição e dedicação à leitura e críticas ao trabalho.

Ao meu orientador Marcelo Andrade. Desde o mestrado, sua supervisão, sugestões, críticas e apoio foram fundamentais para a idealização e condução deste trabalho. Que a tese seja só mais uma etapa de uma parceria longa e profícua!

Gostaria de agradecer também ao meu co-orientador Ralph Levinson. Sua orientação dedicada, presente e cuidadosa durante o doutorado sanduíche em Londres contribuíram enormemente para a análise dos dados e sobre as relações entre criacionismo, evolução e educação. Thank you very much!

À professora Sandra Selles, que me apresentou ao professor Ralph e acompanha meu trabalho desde o mestrado, com importantes sugestões e reflexões para o desenvolvimento da tese.

À professora Cynthia Paes de Carvalho, pelas contribuições em diversos momentos da pesquisa, especialmente com a análise dos dados quantitativos.

Ao professor Luís Fernando Dorvillé, pela parceria e debates ao longo dos últimos anos, traduzidos em congressos e publicações conjuntas.

I would like to acknowledge Paul Davies for the co-supervision during my time in London, the very helpful comments and happy moments, especially during ESERA, in Finland.

À minha esposa, parceira, psicóloga-amadora e porto-seguro, Amanda. Desde o mestrado, aguentando conversas sobre evolução e criacionismo, nunca me negou apoio. Parceira incondicional nos momentos de tensão do trabalho de campo, na leitura dos dados de mais de 400 questionários e no doutorado sanduíche. Sem você, eu não teria metade da coragem e persistência para fazer a tese. Te amo! A meu pai, Delfim, pelo apoio - seja emocional, seja com os dados dos questionários - e dedicação infinitos. Pelo exemplo de superação e transformação pessoal a cada dia. 
A todos os amigos do GECEC, que desde 2010 me ajudam de forma incalculável a tentar ser sempre uma pessoa mais tolerante e um bom pesquisador.

A Fabiano Taranto e a Sandra Marcelino, pela ajuda com as transcrições.

A Felipe Bastos, Luís Fernando Dorvillé, Luiz Câmara, Rachel Pulcino e Raquel Pinho pela ajuda valiosa na aplicação dos questionários.

A André Regis pela ajuda inestimável e atenciosa com a análise dos dados quantitativos e o uso do SPSS.

A todos os meus amigos de São Bento, que há mais de 20 anos demonstram fidelidade e suporte. Especialmente nos momentos de aperto durante o doutorado sanduíche, a ajuda de vocês foi fundamental.

A todos os amigos de Biologia da UFRJ pela amizade verdadeira e duradoura.

To all my friends in London, especially at the IOE. Thank you, guys, for the support, lunches, laughs, coffees and pubs! Hope to meet you all someday, back in London or in Rio!

A todos os/as professores/as, estudantes e escolas que aceitaram participar da pesquisa. Sempre me receberam de boa vontade e de braços abertos para que eu conduzisse o trabalho de campo e contribuíram enormemente para o desenvolvimento da tese.

A todos/as os/as funcionários/as e professores/as Departamento de Educação da PUC-Rio pelos ensinamentos, suporte e ajuda.

À CAPES e ao CNPq pelo auxílio financeiro na forma de ajuda de custo, bolsas no país e no exterior, sem os quais esta pesquisa não seria possível. 


\section{Resumo}

Teixeira, Pedro Pinheiro; Andrade, Marcelo Gustavo. Ensino de evolução e religiosidade: o caso de duas escolas estaduais do Rio de Janeiro. Rio de Janeiro, 2016. 280 p. Tese de Doutorado - Departamento de Educação, Pontifícia Universidade Católica do Rio de Janeiro.

A teoria evolutiva é considerada um dos eixos organizadores da biologia. No entanto, seu ensino enfrenta diversas dificuldades em vários países. No Brasil, a resistência à teoria evolutiva é mais comum entre os evangélicos pentecostais e neopentecostais, grupos religiosos que passaram por intenso crescimento ao longo das últimas décadas. Nesta pesquisa, investigamos o ensino de evolução em duas escolas da rede estadual do Rio de Janeiro. Realizamos observações ao longo de nove meses, em turmas de primeiro ano do ensino médio, entrevistas com professores e estudantes e aplicamos um questionário aos últimos. Os resultados indicam grande complexidade e diversidade em relação às concepções de criacionismo e evolução por parte dos professores e estudantes, mesmo dentre os evangélicos pentecostais e neopentecostais. Poucos conflitos foram observados em sala de aula, porém eles foram expressos nas entrevistas e nos questionários. Os dados quantitativos indicam que os estudantes evangélicos tendem a aceitar mais a narrativa bíblica para a origem dos seres vivos e possuir maiores índices de religiosidade do que os demais grupos religiosos. Concluímos que mais pesquisas sobre as discussões sobre essa temática nas aulas de biologia são fundamentais para que estratégias didáticas que visem o entendimento da teoria evolutiva sejam desenvolvidas.

\section{Palavras-chave}

Ensino de Ciências; Ensino de Biologia; Evolução; Criacionismo; Religiosidade; Pentecostais 


\section{Abstract}

Teixeira, Pedro Pinheiro; Andrade, Marcelo Gustavo (Advisor). The teaching of evolution and religiousness: the case of two state schools in Rio de Janeiro. Rio de Janeiro, 2016. 280 p. PhD Thesis - Departamento de Educação, Pontifícia Universidade Católica do Rio de Janeiro.

The evolutionary theory is considered one of main axes of biology. However, its teaching faces many difficulties in several countries. In Brazil, the resistance to evolutionary theory is more common among Pentecostal and neoPentecostal, religious groups that have strongly grown over the past decades. In this study, we investigated the teaching of evolution in two schools in the state of Rio de Janeiro. We performed observations over nine months in classes of the first year of high school, interviews with teachers and students and applied a questionnaire to latter. The results indicate great complexity and diversity in relation to the concepts of creationism and evolution among teachers and students, even among the Pentecostal and neo-Pentecostal. Few conflicts were observed in the classroom, but they were expressed in the interviews and questionnaires. Quantitative data indicate that Pentecostal and Neo-Pentecostal students tend to accept more the biblical account of the origin of living beings and have greater religiosity rates than other religious groups. We conclude that more research on this topic in biology classes are essential to develop teaching strategies aimed at understanding the evolutionary theory.

\section{Keywords}

Science teaching; Biology teaching; Evolution; Creationism; Religiousness; Pentecostals 


\section{Sumário}

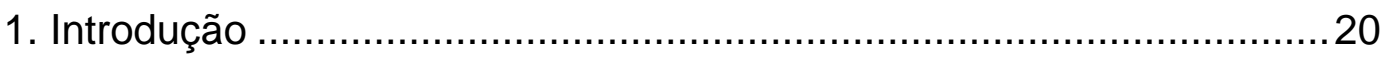

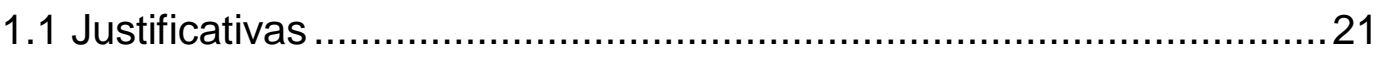

1.2 Questões de pesquisa........................................................23

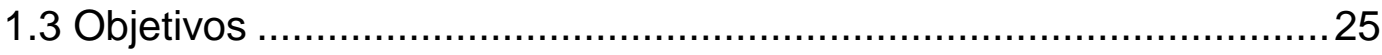

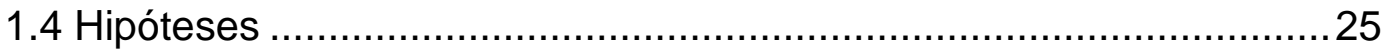

1.5 Referenciais teórico-metodológicos ...........................................26

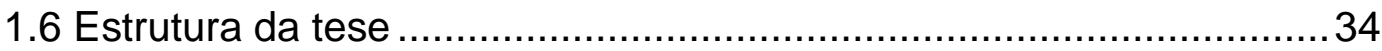

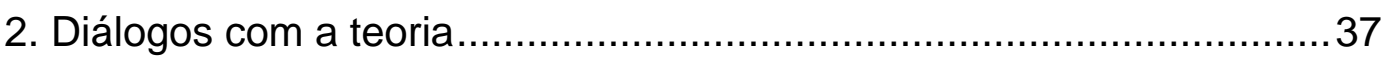

2.1 A importância da evolução para a biologia e os objetivos do ensino de ciências ...................................................................................... 37

2.2 Evangélicos pentecostais e neopentecostais: crescimento e

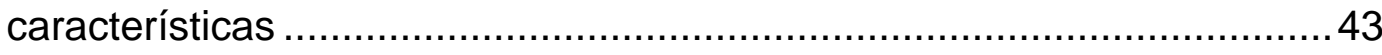

2.3 Multiculturalismo e interculturalidade: perspectivas de análise ..........58

$2.4 \mathrm{O}$ modelo de espaço de busca baseado no Discurso Habermasiano ...................................................................... 63

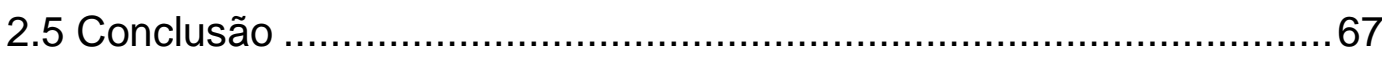

3. Campo e sujeitos de pesquisa .................................................69

3.1 O ensino de biologia no primeiro ano do ensino médio da rede

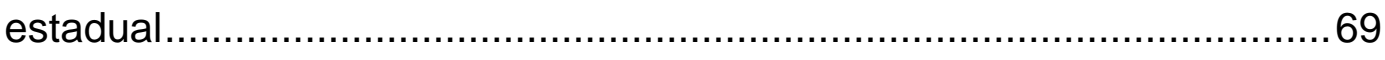

3.2 O Colégio Guarani............................................................... 72

3.2.1 Os estudantes do Colégio Guarani .......................................... 74

3.2.2 Os professores do Colégio Guarani ......................................... 78

3.3 O Colégio Passaredo ............................................................. 82

3.3.1 Os estudantes do Colégio Passaredo ......................................... 84

3.3.2 Os professores do Colégio Passaredo ......................................... 89

3.4 A presença religiosa nas escolas pesquisadas ..............................91

3.5 Uma tentativa de síntese ...........................................................96 
4. Concepções dos professores sobre criacionismo e evolução

4.1 Concepções de P1 sobre evolução e criacionismo: verdade e conforto na evolução

4.2 Concepções de P7 sobre evolução e criacionismo: uma visão budista.

4.3 Concepções e estratégias de P2 para conciliar a evolução e o criacionismo: nosso lugar no universo e o uso dúbio de "teoria".

4.4 Concepções e estratégias de P3: flexibilização de conceitos científicos e religiosos

4.5 Concepções e estratégias de P4: cruzamento de ciência, cristianismo e espiritismo

4.6 Concepções e estratégias de P5: críticas e flexibilizações aos conhecimentos científico e religioso.

4.7 Concepções e estratégias de P6: a evolução junto com a criação ..122

4.8 Semelhanças e diferenças entre os professores que conciliam suas crenças religiosas com suas ideias sobre evolução

4.9 Conclusão

5. Concepções dos(as) estudantes sobre criacionismo e evolução ......131

5.1 As concepções dos estudantes entrevistados.

5.2 Análise quantitativa dos questionários aplicados aos estudantes ....144

5.2.1 Aceitação da teoria evolutiva neodarwinista

5.2.2. Construção do índice de entendimento da teoria evolutiva neodarwinista

5.2.3 Construção do índice de religiosidade 165

5.2.4 Correlações 176

5.3 Síntese 182

6. As relações entre religião, ciência, criacionismo e evolução em sala de aula

6.1 Aulas de P1: entre comprovações e céus 184

6.2 Aulas de P2: tentativas de diálogo e receios. 193

6.3 Aulas de P3: questionamentos e resistências 203

6.4 Aulas de P4: religião e ciência se encontram 213

6.5 Aulas de P5: fronteiras entre saber e acreditar 220

6.6 Aulas de P6: tensões expostas e veladas 
6.7 Aulas de P7: tensões expostas, mas poucas reações …..................229

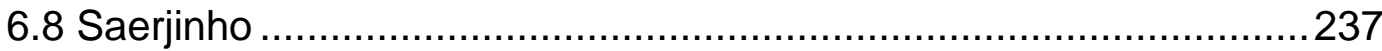

6.9 Distribuição dos índices e variáveis por turmas: levantando hipóteses para a possibilidade de conflito ...........................................239

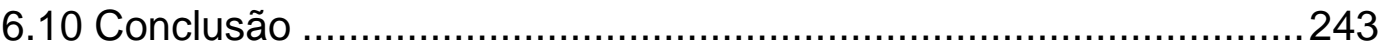

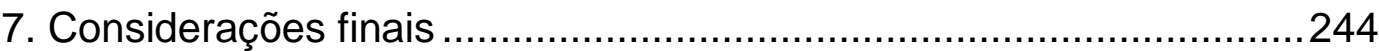

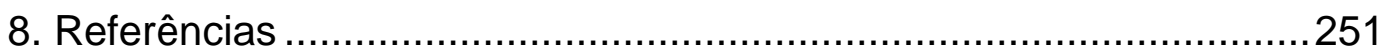

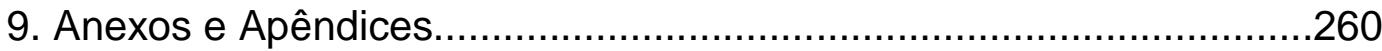

Apêndice 1 - Questionário aplicado aos estudantes..............................260

Apêndice 2 - Roteiro de entrevista dos professores .............................265

Apêndice 3 - Roteiro de entrevista dos estudantes .............................267

Apêndice 4 - Perfil profissional dos professores ...................................268

Apêndice 5 - Perfil religioso dos professores........................................269

Apêndice 6 - Perfil dos estudantes entrevistados ................................270

Apêndice 7 - Ficha de identificação para os professores....................... 273

Apêndice 8 - Variáveis utilizadas para as correlações ..........................273

Apêndice 9 - Lista de temas e códigos ................................................2274

Anexo 1 - Currículo Mínimo de Biologia para o $1^{\circ}$ ano do ensino médio

Anexo 2 -Matriz do Saerjinho para Biologia do $1^{\circ}$ ano do ensino médio

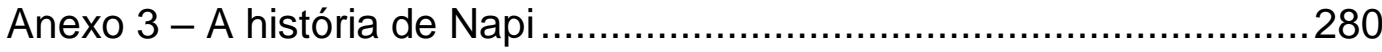




\section{Lista de tabelas e quadros}

Tabela.1.1: Teses e dissertações relacionadas com tema de nossa pesquisa. Fonte: Oliveira (2011); Banco de Teses da CAPES.

Tabela 1.2: Distribuição percentual da população residente no município do Rio de Janeiro segundo os grupos de religião (Fonte: Censo 2010)......27

Tabela 1.3: Distribuição percentual da população residente no município de Nilópolis segundo os grupos de religião (Fonte: Censo 2010).

Tabela 2.1: População total e grupos religiosos. Fonte: Jacob, Hees et al. (2013)/ IBGE, Censos Demográficos de 1980, 1991, 2000 e 2010.

Tabela 2.2: Distribuição de evangélicos de origem pentecostal pelas áreas de ponderação da cidade do Rio de Janeiro. Apenas as dez áreas de maior concentração foram indicadas. Fonte: IBGE, Censo Demográfico 2010.

Tabela 3.1: Distribuição dos estudantes do Colégio Guarani participantes da pesquisa de acordo com o bairro em que residem ( $\left.n_{G}=399\right)$.

Tabela 3.2: Distribuição dos estudantes pesquisados do Colégio Guarani de acordo com seus grupos religiosos ( $\left.n_{\mathrm{G}}=399\right)$.

Tabela 3.3: Sexo dos estudantes participantes da pesquisa no Colégio Guarani $\left(n_{\mathrm{G}}=399\right)$.

Tabela 3.4: Cor/raça dos estudantes participantes da pesquisa no Colégio Guarani ( $n \mathrm{G}=399)$

Tabela 3.5: Idade dos estudantes participantes da pesquisa no Colégio Guarani $\left(n_{\mathrm{G}}=399\right)$.

Tabela 3.6: Distribuição dos estudantes do Colégio Passaredo participantes da pesquisa de acordo com a cidade em que residem $\left(n_{P}=142\right)$

Tabela 3.7: Distribuição dos estudantes do Colégio Passaredo participantes da pesquisa de acordo com o bairro em que residem $\left(n_{\mathrm{P}}=142\right)$

Tabela 3.8: Distribuição dos estudantes pesquisados do Colégio Passaredo de acordo com seus grupos religiosos ( $n \mathrm{P}=142$ ). 
Tabela 3.9: Sexo dos estudantes participantes da pesquisa no Colégio Passaredo $\left(n_{P}=142\right)$

Tabela 3.10: Cor/raça dos estudantes participantes da pesquisa no Colégio Passaredo $(\mathrm{nP}=142)$.

Tabela 3.11: Idade dos estudantes participantes da pesquisa no Colégio

Passaredo ( $\mathrm{nP}=142)$.

Quadro 4.1: Estratégias dos professores P2, P3, P4, P5 e P6 para conciliar evolução e criacionismo.

Quadro 5.1: Construtos medidos pelos itens do questionário aplicado aos estudantes

Tabela 5.1: Frequência (\%) e média das respostas relacionadas à aceitação da teoria evolutiva neodarwinista pelos alunos do Colégio Guarani $(n=399)$. A escala vai de 1 (não acredito) até 5 (acredito fortemente)

Tabela 5.2: Frequência (\%) das respostas relacionadas à aceitação da teoria evolutiva neodarwinista pelos alunos do Colégio Passaredo $(n=142)$. A escala vai de 1 (não acredito) até 5 (acredito fortemente).

Tabela 5.3: Análise fatorial para os itens de aceitação da teoria evolutiva neodarwinista. Apenas as cargas superiores a 0,30 são mostradas.

Tabela 5.4: Análise fatorial para os itens de aceitação da teoria evolutiva neodarwinista. Apenas as cargas superiores a 0,30 são mostradas.

Tabela 5.5: Análise fatorial para os itens de aceitação da teoria evolutiva neodarwinista. Apenas as cargas superiores a 0,30 são mostradas.

Tabela 5.6: Média, N, desvio padrão e mediana dos fatores AC e NB dos diferentes grupos religiosos. $\mathrm{O} \mathrm{N}$ total difere do total de participantes da pesquisa, pois alguns respondentes deixaram questões em branco e foram excluídos do cálculo do índice

Tabela 5.7: Testes post hoc ao de Kruskal-Wallis para o Fator AC 160

Tabela 5.8: Testes post hoc ao de Kruskal-Wallis para o Fator NB. Em amarelo, estão destacados os cruzamentos diferentes com a significância ajustada. 
Tabela 5.9: Frequências (porcentagem) de respostas certas e erradas para cada uma das questões de entendimento da teoria evolutiva neodarwinista

Tabela 5.10: Média, desvio padrão e mediana do escore de entendimento da evolução por escola.

Tabela 5.11: Médias do escore de entendimento de evolução para os grupos de religião.

Tabela 5.12: Análise fatorial para os itens de religiosidade intrínseca (RI)...166

Tabela 5.13: Média, desvio padrão e mediana da Religiosidade Intrínseca para os grupos religiosos.

Figura 5.3: Acima: Diagrama de box-plot de frequências da Religiosidade Intrínseca de acordo com os grupos religiosos. Abaixo: Resultado do teste $\mathrm{H}$ de Kruskal-Wallis

Tabela 5.14: Média, desvio padrão e mediana da RO para as escolas pesquisadas

Tabela 5.15: Médias, desvio padrão e mediana da Religiosidade Organizacional $(\mathrm{RO})$ para os grupos de religião

Tabela 5.16: Média, desvio padrão e mediana da RNO para as escolas pesquisadas

Tabela 5.17: Médias, desvio padrão e mediana da Religiosidade Organizacional $(\mathrm{RO})$ para os grupos de religião

Figura 5.5: Acima: Diagrama de box-plot de frequências da Religiosidade Intrínseca de acordo com os grupos religiosos. Abaixo: Resultado do teste $\mathrm{H}$ de Kruskal-Wallis.

Tabela 5.18: Correlações ( $\rho$ de Spearman) entre os fatores AC, NB, Entendimento da evolução, RI, RO e RNO

Tabela 5.19: Correlações ( $\rho$ de Spearman) entre os índices criados para a pesquisa, religião, sexo e cor dos estudantes.

Tabela 5.20: Correlações ( $\rho$ de Spearman) entre os índices criados para a pesquisa, idade, cidade onde mora, gosta de estudar de biologia, faz dever de casa de biologia, professores corrige dever de biologia, estudou somente em escola pública desde o $6^{\circ}$ ano e escolaridade máxima dos responsáveis 
Tabela 5.21: As dez turmas com menores médias do fator AC. 239

Tabela 5.22: As dez turmas com maiores médias do fator NB....................240

Tabela 5.23: As dez turmas com maiores médias de RI.............................240

Tabela 5.24: As dez turmas com maiores médias de RO...........................240

Tabela 5.25: As dez turmas com maiores médias de RNO........................... 241

Tabela 5.26: As dez turmas com menores médias de Entendimento da Evolução

Tabela 5.27: As dez turmas com maiores frequências de estudantes evangélicos. 


\section{Lista de figuras e gráficos}

Figura 2.1: Religião Católica Apostólica Romana 2010. Fonte: Jacob, Hees et. al. (2013), IBGE, Censo Demográfico 2010 ................................45

Figura 2.2: Religião Católica Apostólica Romana 2010. Fonte: Jacob, Hees et. al. (2013), IBGE, Censo Demográfico 2010

Figura 2.3: Religião Católica Apostólica Romana. Variação absoluta e relativa 1991/2010 (com desconto do crescimento demográfico) Fonte: Jacob, Hees et. al. (2013), IBGE, Censo Demográfico 2010.

Figura 2.4: Religiões Evangélicas Pentecostais 2010. Fonte: Jacob, Hees et. al. (2013), IBGE, Censo Demográfico 2010

Figura 2.5: Religiões Evangélicas Pentecostais 2010. Fonte: Jacob, Hees et. al. (2013), IBGE, Censo Demográfico 2010.

Figura 2.6: Religiões Evangélicas Pentecostais. Variação absoluta e relativa 1991/2010 (com desconto do crescimento demográfico). Fonte: Jacob, Hees et. al. (2013), IBGE, Censo Demográfico 2010.

Gráfico 3.1: Idade dos estudantes participantes da pesquisa no Colégio Guarani ( $\mathrm{nG}=399)$.

Gráfico 3.2: Idade dos estudantes participantes da pesquisa no Colégio Passaredo (nP=142) 88

Figura 4.1: Concepções de P1 sobre evolução e criacionismo......................98

Figura 4.2: Concepções de P7 sobre evolução e criacionismo.....................102

Figura 4.3: Estratégias de P2 para conciliar criacionismo e evolução........... 106

Figura 4.4: Estratégias de P3 para conciliar criacionismo e evolução.......... 109

Figura 4.5: Estratégias de P4 para conciliar criacionismo e evolução........... 114

Figura 4.6: Estratégias de P5 para conciliar criacionismo e evolução..........119

Figura 4.7: Estratégias de P6 para conciliar criacionismo e evolução...........123

Figura 5.1: Estudantes entrevistados de acordo com o gradiente de concepções sobre origem da Terra, da vida e dos seres humanos. 
Gráfico 5.1: Frequências do Fator de Aceitação dos Aspectos Científicos da Teoria Evolutiva (AC) para os estudantes de ambos os colégios. Mediana $=0,13$

Gráfico 5.2: Frequências do Fator de Aceitação da Narrativa Bíblica para a Origem e Evolução dos Seres Vivos (NB) para os estudantes de ambos os colégios

Gráfico 5.3: Frequências do Fator AC para os estudantes do Colégio Guarani.....

Gráfico 5.4: Frequências do Fator AC para os estudantes do Colégio Passaredo

Gráfico 5.5: Frequências do Fator AC para os estudantes do Colégio Guarani

Gráfico 5.6: Frequências do Fator NB para os estudantes do Colégio Passaredo

Figura 5.2: Teste $\mathrm{H}$ de Kruskal-Wallis do fator AC para os grupos de religião

Figura 5.3: Teste $\mathrm{H}$ de Kruskal-Wallis do fator NB para os grupos de religião

Gráfico 5.7: Frequências do escore de entendimento de evolução. Mediana $=-0,234391$

Gráfico 5.8: Frequências do escore de entendimento de evolução dos estudantes do Colégio Guarani.

Gráfico 5.9: Frequências do escore de entendimento de evolução dos estudantes do Colégio Guarani.

Gráfico 5.10: Frequências da Religiosidade Intrínseca (RI) para os estudantes do Colégio Guarani. Média $=-0,7337$; Desvio padrão = 0,96733; Mediana $=0,15$

Gráfico 5.11: Frequências da Religiosidade Intrínseca (RI) para os estudantes do Colégio Passaredo. Média $=0,20587$; Desvio padrão $=$ 1,06325; Mediana $=0,43$

Gráfico 5.12: Frequências da Religiosidade Organizacional (RO) para os estudantes do Colégio Guarani 
Gráfico 5.13: Frequências da Religiosidade Organizacional (RO) para os estudantes do Colégio Passaredo.

Figura 5.4: Testes post-hoc ao de Kruskal-Wallis para a RO. Acima: Diagrama mostrando as distâncias entre os grupos de religião. Os números representam as médias dos ranks de cada amostra. Abaixo: Em destaque, estão os cruzamentos diferentes com a significância ajustada....171

Gráfico 5.14: Frequências da Religiosidade Não Organizacional (RNO) para os estudantes do Colégio Guarani.

Gráfico 5.15: Frequências da Religiosidade Não Organizacional (RNO) para os estudantes do Colégio Passaredo.

Figura 5.6: Testes post-hoc ao de Kruskal-Wallis para a RO. Acima: Diagrama mostrando as distâncias entre os grupos de religião. Os números representam as médias dos ranks de cada amostra. Abaixo: Em destaque, estão os cruzamentos diferentes com a significância ajustada....175

Figura 6.1: Modelo do espaço de busca para P1 .......................................193

Figura 6.2: Modelo do espaço de busca para P2 ......................................202

Figura 6.3: Modelo do espaço de busca para P3.....................................212

Figura 6.4: Modelo do espaço de busca para P4 ......................................219

Figura 6.5: Modelo do espaço de busca para P5 ........................................223

Figura 6.6: Cartum comparando o "método científico" e o "método criacionista". Fonte: "Caderno de Atividades Pedagógicas de Aprendizagem Autorregulada" (SEEDUC, s/d) ......................................... 224

Figura 6.7: Modelo do espaço de busca para P6 ......................................228

Figura 6.8: Frame do primeiro episódio de Cosmos representando membros da Igreja Católica (Copyright @ 2014 Cosmos Studios/ Fuzzy Door Productions/ National Geographic Channel/ Six Point Harnnes/ Fox). 233

Figura 6.9: Frame do primeiro episódio de Cosmos representando Giordano Bruno em um sonho, viajando pelo universo (Copyright (C) 2014 Cosmos Studios/ Fuzzy Door Productions/ National Geographic Channel/ Six Point Harnnes/ Fox)

Figura 6.10: Frame do segundo episódio de Cosmos em que Neil deGrasse Tyson afirma que "aceitar nosso parentesco com toda forma de vida na Terra, não é apenas um fato científico. Na minha opinião, é 
também uma experiência espiritual" (Copyright @ 2014 Cosmos Studios/ Fuzzy Door Productions/ National Geographic Channel/ Six Point Harnnes/ Fox) ...............................................................................235

Figura 6.11: Modelo do espaço de busca para P6....................................237 


\section{Lista de siglas e abreviações}

AC

AFE

ANPED

BSGI

CRBio

DUREL

FTESM

GLP

IBGE

INEP

JBRJ

MATE

MEC

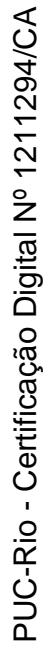

NB

PTB

PUC-Rio

$\mathrm{RI}$

RNO

RO

SAEB

SAERJ

SAERJINHO

SEEDUC

SEPE

SINPRO

UERJ

UFRJ

UFRRJ

UNIG

UNESA

USU
Fator Aceitação dos Aspectos Científicos da Teoria Evolutiva

Associação Fluminense de Ensino

Associação Nacional de Pós-Graduação e Pesquisa em Educação

Brasil Soka Gakkai Internacional

Conselho Regional de Biologia

Duke University Religion Index

Fundação Técnico Educacional Souza Marques

Gratificação por Lotação Prioritária

Instituto Brasileiro de Geografia e Estatística

Instituto Nacional de Estudos e Pesquisas Educacionais Anísio Teixeira

Jardim Botânico do Rio de Janeiro

Measure of Acceptance of the Theory of Evolution

Ministério da Educação

Fator Aceitação da Narrativa Bíblica para a Origem dos Seres Vivos

Partido Trabalhista Brasileiro

Pontifícia Universidade Católica do Rio de Janeiro

Religiosidade Intrínseca

Religiosidade Não Organizacional

Religiosidade Organizacional

Sistema de Avaliação da Educação Básica

Sistema de Avaliação da Educação do Estado do Rio de Janeiro

Sistema de avaliação bimestral do Estado do Rio de Janeiro

Secretaria Estadual de Educação.

Sindicato Estadual dos Profissionais de Educação

Sindicato dos Professores do Município do Rio de Janeiro e Região

Universidade do Estado do Rio de Janeiro.

Universidade Federal do Rio de Janeiro.

Universidade Federal Rural do Rio de Janeiro.

Universidade Iguaçu

Universidade Estácio de Sá.

Universidade Santa Úrsula. 


\section{1.}

\section{Introdução}

As relações entre ciência e religião não se restringem aos dias de hoje, remontando ao surgimento da chamada ciência moderna, na revolução científica do século XVI(HENRY, 1998). Ainda que a imagem de conflito seja a mais recorrente para representar esta relação, tal concepção é limitada(BARBOUR, 2000).Importantes pensadores como Galileu e Newton, por exemplo, embora estivessem dando os primeiros passos no sentido de formar o pensamento científico, eram profundamente religiosos. A história desse relacionamento, no entanto, está marcada por afastamentos e aproximações(BROOKE, 1991).

A publicação do livro “A Origem das Espécies por Meio da Seleção Natural ou a Preservação de Raças Favorecidas na Luta pela Vidal”, de Charles Darwin, em 1859, é um dos marcos na relação entre ciência e religião. Nesta obra, Darwin defende a ideia da evolução dos seres vivos por meio de modificações graduais e extinções ao longo de milhões de anos, através do processo de seleção natural. Tal teoria logo causou grande impacto no meio científico e reação por parte de membros de diferentes religiões por ir de encontro às crenças criacionistas, em especial a cristã, para a qual Deus havia criado o universo e todos os seres vivos, tais como eles são em suas formas atuais, bem como o ser humano a sua imagem e semelhança(MAYR, 1982).

Atualmente, é possível afirmar que a evolução é o conceito mais importante da biologia (MAYR, 2009). Ela respondeu e continua a responder a diversas perguntas sobre as formas dos seres vivos atuais e extintos e, cada vez mais, amplia os horizontes das ciências biológicas. Com os avanços de outras áreas, como a genética, e o desenvolvimento de equipamentos e técnicas mais precisas, a biologia evolutiva é um campo de bases sólidas e de constante inovação.

No entanto, passados mais de 150 anos da publicação de "A Origem das Espécies”, vivemos em um mundo não menos religioso que o de Darwin. O ideal iluminista de avanço da razão independente das crenças religiosas que serviu de pressuposto para as teorias de secularização (BERGER, 1985), não se 
concretizou. Berger (2001)revê suas ideias acerca da secularização e afirma que, embora tenha produzido um efeito secularizante, a modernidade também gerou poderosos movimentos de contra-secularização. Além disso, a secularização da sociedade não está necessariamente vinculada à secularização da consciência individual. Assim, de acordo com Berger(2001), não há hoje elementos suficientes para afirmar que as crenças religiosas estaria em crise ou viriam a se extinguir.

Para o argumento desta pesquisa, devemos destacar ainda o surgimento e o desenvolvimento de diversos grupos religiosos que reagem à secularização, como os evangélicos pentecostais e neopentecostais no Brasil, que vêm crescendo fortemente nas últimas décadas (CPS/FGV, 2011).Estas denominações, em geral, têm se popularizado nas periferias pobres de grandes centros urbanos, com destaque para Rio de Janeiro e São Paulo(JACOB et al., 2013). Caracterizam-se pelo reduzido aprofundamento de estudos teológicos, por uma moral que exalta determinados valores conservadores, pela Teologia da Prosperidade $^{1}$ e pela flexibilização de hábitos e costumes do pentecostalismo clássico (MARIANO, 1999). Paralelamente, professores que seguem crenças que realizam leituras literais de livros sagrados tendem a rejeitar e não compreender a fundo a teoria da evolução(BLACKWELL; POWELL; DUKES, 2003; BOUJAOUDE et al., 2011).

Nesse sentido, suponho que o ensino de evolução em um contexto de forte presença de estudantes pentecostais e neopentecostais é propício para tensões entre dois tipos de conhecimento potencialmente concorrentes: o científico e o religioso. Há conflitos nessas aulas? De que tipo? Como o professor lida com essa situação? Qual a postura dos alunos? Foi a partir dessas inquietações iniciais que nasceu esta pesquisa.

\section{1}

\section{Justificativas}

A relevância desta pesquisa se dá por diferentes motivos. Por um lado, pelo crescimento dos grupos evangélicos pentecostais e neopentecostais nas últimas décadas em nosso país e pelas mudanças sociais que têm desencadeado e,

\footnotetext{
${ }^{1}$ Doutrina que defende que é a vontade de Deus que o fiel está destinado a ser próspero, saudável e feliz nesse mundo, mediante o sacrifício de natureza financeira, o dízimo (MARIANO, 1999).
} 
por outro lado, pela potencialidade do conhecimento científico para uma leitura mais crítica do mundo. Entender o cruzamento desses fatores no cotidiano escolar e, mais especificamente, sua dinâmica dentro de sala de aula, poderá oferecer novos elementos para um ensino de evolução que atenda às expectativas curriculares e legais, e também que respeite a diversidade de crenças presente na escola.

Em minha pesquisa de mestrado (TEIXEIRA, 2012), entrevistei dez professores de biologia que professavam uma fé religiosa cristã. Todos se consideravam criacionistas, porém rejeitavam a leitura literal da Bíblia e aceitavam, de diferentes maneiras, a evolução. Todavia, de um modo geral, os professores entrevistados acreditavam que Deus é quem guia o processo evolutivo. Parte deles afirmava que não ensinava o criacionismo por se tratar de um conhecimento não-científico. Contudo, parte o ensinava alegando estar mostrando diferentes explicações para um mesmo fenômeno. Estes professores não deixavam claro se apresentavam a teoria evolutiva e o criacionismo como igualmente válidos do ponto de vista científico. Este "ponto cego" da minha pesquisa de mestrado se constitui em uma motivação a mais para prosseguir com o tema.

As relações entre a teoria da evolução e alguns preceitos da religião na educação básica vêm sendo amplamente estudadas no mundo e no Brasil. Vale destacar os trabalhos de Smith(2010a, 2010b), que analisou 216 trabalhos para formular um estado de arte da pesquisa sobre ensino de evolução. Já no contexto brasileiro, de acordo com Oliveira (2011)e o banco de teses da CAPES, há 48 teses e dissertações relacionadas a esse tema no período entre 2002 e 2012 como indica a tabela 1 abaixo:

\begin{tabular}{lcccccccccccc}
\hline Ano & 02 & $\mathbf{0 3}$ & $\mathbf{0 4}$ & $\mathbf{0 5}$ & $\mathbf{0 6}$ & $\mathbf{0 7}$ & $\mathbf{0 8}$ & $\mathbf{0 9}$ & $\mathbf{1 0}$ & $\mathbf{1 1}$ & $\mathbf{1 2}$ & TOTAL \\
Dissertações & 1 & 2 & 5 & 3 & 3 & 3 & 8 & 2 & 2 & 8 & 4 & 41 \\
Teses & 0 & 0 & 0 & 0 & 1 & 1 & 0 & 2 & 3 & 0 & 0 & 7 \\
\hline
\end{tabular}

Tabela.1.1: Teses e dissertações relacionadas com tema desta pesquisa. Fonte: Oliveira (2011) Banco de Teses da CAPES

É interessante notar que, apesar do grande volume de trabalhos nessa área, esta pesquisa visa explorar, mais especificamente, o cotidiano da sala de aula e as relações que se estabelecem entre professores, estudantes, conteúdos de biologia e 
religiosidades. Diferentemente da maioria da produção sobre o tema, que se baseia em questionários e entrevistas, a observação da sala de aula ocupou lugar central nessa investigação. Assim, por meio de um procedimento de pesquisa pouco explorado em trabalhos nesta temática, buscaremos construir novas reflexões sobre esse tema. Além disso, procuramos investigar a religiosidade dos sujeitos de pesquisa, a fim de entender como interpretam, acreditam e entendem a realidade em que vivem e de que forma isso os fazem aceitar ou rejeitar determinados aspectos da teoria evolutiva. Por fim, cumpre registrar que, no cenário nacional, há poucas teses de doutorado (7) se comparadas às dissertações (41), o que indica uma demanda por estudos mais aprofundados sobre essas temáticas.

Uma vez que a ciência ocupa um lugar de prestígio e de grande influência em nossa sociedade - o que, certamente, pode ser problematizado - entender um conhecimento que se configura como eixo central da biologia é de grande importância para que o estudante saiba analisar criticamente determinados temas científicos. Paralelamente, a forma como a teoria da evolução é trabalhada em sala de aula pelo(a)professor(a) de biologia também é de grande relevância. Por um lado, para que não se negligencie ou deturpe suas bases. Por outro, para que não discrimine as crenças dos estudantes, impondo a ciência como a verdade absoluta.

Acreditamos que esta pesquisa possa contribuir para aprofundar as discussões sobre as mudanças que o crescimento de evangélicos pentecostais e neopentecostais tem causado no contexto escolar, em especial, nas aulas sobre evolução e origem da vida. Diversos trabalhos, como discutiremos adiante, relatam situações de conflito entre estudantes e professores/as em relação a esse tema. Nesse sentido, não nos propomos a ser prescritivos e encontrar receitas para como superar embates em sala de aula, mas sim entender melhor quais as características desses conflitos e de que forma as crenças religiosas pentecostais e neopentecostais se relacionam com eles.

\section{2}

\section{Questões de pesquisa}

Considerando as reflexões apresentadas e a trajetória de estudos realizada, acreditamos ser possível investigar o problema de pesquisa a partir de uma perspectiva intercultural, numa abordagem ética e epistemológica. Buscando 
dialogar com a religiosidade dos professores de biologia e de seus estudantes, não acreditamos que a religião seja algo restrito a pessoas "atrasadas", "supersticiosas" ou "reacionárias". Concordamos com Geertz (2001) quando afirma que a religião não é apenas uma máscara ou um encobrimento ideológico de ambições perfeitamente seculares, mas sim um sistema cultural complexo, ou seja, uma rede de significados que nos permite construir sentidos compartilhados sobre diferentes aspectos da vida social.

Paralelamente, pretendemos dialogar com o pensamento de Adela Cortina no sentido de encarar a religião como um "máximo de felicidade" possível, isto é, um projeto pessoal e intransferível pelo qual os cidadãos de uma sociedade plural podem livremente optar (CORTINA, 1996). Assim, consideramos que professores e estudantes desta pesquisa optaram por uma religião como um horizonte de sentido complexo e felicitante dentro de um sistema cultural, tal como nos sugerem Geertz (2001) e Cortina (1996). No entanto, também entendemos que ao assumir a tarefa de ensinar biologia é preciso que o professor domine e efetivamente trabalhe os conceitos ligados à teoria da evolução e que o objetivo do ensino desse mínimo comum compartilhado deva ser o seu entendimento e não a mudança de crença dos educandos.

Dessa maneira, algumas indagações foram sendo formuladas e elas guiaram esse trabalho de pesquisa:

- Existe para o(a) estudante que professa fé de orientação pentecostal ou neopentecostal relação entre evolução biológica e criacionismo? Se sim, como ele/a entende essa relação?

- Qual o significado que a religião desempenha na vida do estudante que professa uma religião pentecostal ou neopentecostal? Qual o lugar da religião na construção da sua identidade?

- Qual o significado que a biologia ocupa na vida do estudante que professa uma religião pentecostal ou neopentecostal? Qual o lugar da ciência e da biologia na construção de sua identidade?

- Como os/as estudantes que professam uma religião pentecostal ou neopentecostal e seus professores/as definem a evolução biológica? E o criacionismo? 
- A evolução biológica e o criacionismo são abordados nas aulas? De que forma? Há conflitos? Se sim, o professor consegue resolvê-los? Há conflitos com outros temas? Quais? O professor consegue resolvê-los?

\section{3}

\section{Objetivos}

Considerando um contexto de forte presença pentecostal e neopentecostal e tomando como base as questões levantadas anteriormente, este trabalho teve como objetivos:

1) Identificar as relações, os conflitos e as aproximações entre a evolução biológica e o criacionismo em aulas de biologia em um contexto de forte presença pentecostal e neopentecostal.

2) Analisar como o(a)professor(a) de biologia e os/as estudantes lidam com possíveis conflitos em sala de aula em torno dos temas de evolução e criacionismo.

3) Compreender que características das crenças ou da ausência de crenças de professores/as e estudantes podem contribuir ou se tornarem obstáculos para o processo de ensino-aprendizagem da teoria da evolução.

\section{4}

\section{Hipóteses}

A partir das considerações realizadas anteriormente, das questões levantadas e dos objetivos propostos sintetizamos nossas hipóteses de pesquisa.

- H1: Estudantes que professam uma religião evangélica de orientação pentecostal ou neopentecostal tendem a identificar conflitos entre suas crenças e a teoria da evolução.

- H2: Esses conflitos estão mais ligados a diferenças entre determinadas afirmações científicas e elementos da moral religiosa do que a diferenças epistemológicas entre ciência e religião. 
- H3: Esses conflitos fazem com que os educandos realizem um percurso compreensivo tensionado entre moral religiosa e conhecimento científico em relação à compreensão da teoria evolutiva.

Cabe ressaltar que assumimos a posição de que as hipóteses em ciências humanas e sociais possuem um caráter de pressupostos dos quais o pesquisador inicia sua reflexão e pesquisa e, não necessariamente, se procura comprová-las.

\section{5}

\section{Referenciais teórico-metodológicos}

Do ponto de vista metodológico, esta é uma pesquisa que se propõe trabalhar na articulação quanti-quali. Tal escolha se deu em função do problema apresentado e dos objetivos propostos, que se caracterizam por ser uma análise possível sobre as relações estabelecidas por professores e estudantes na tensão entre teoria da evolução e criacionismo em sala de aula.

Os sujeitos da pesquisa são professores/as de biologia e estudantes de $1^{\circ}$ ano do ensino médio de duas escolas estaduais do Rio de Janeiro. Foi escolhida essa série da escolarização básica, pois, segundo o currículo mínimo oficializado e assumido pela Secretaria de Educação do Estado do Rio de Janeiro (SEEDUC, 2012a), é, nesta série, que os conteúdos de evolução e origem da vida são abordados, o que potencialmente nos facilitaria ver os possíveis conflitos entre fé religiosa e o ensino da teoria da evolução.

A escolha por duas escolas se deu em função da distribuição dos evangélicos pentecostais de acordo com os dados do Censo Demográfico de 2010 (IBGE, 2012), explicitados nas tabelas 1.2 e 1.3 apresentadas a seguir, e pela nossa rede de contatos. O estado do Rio de Janeiro se destaca no cenário nacional pela força das denominações evangélicas pentecostais e neopentecostais nos bairros periféricos da capital e também em sua Região Metropolitana. Uma das escolas pesquisadas, o Colégio Guarani² ${ }^{2}$ está localizada no bairro da Gávea, região nobre da Zona Sul da capital fluminense, porém atende majoritariamente a estudantes de camadas populares moradores de comunidades próximas e de alguns bairros da Zona Oeste da cidade. A segunda escola, o Colégio Passaredo,

\footnotetext{
${ }^{2}$ Todos os nomes utilizados são fictícios a fim de proteger a real identidade das escolas e dos participantes da pesquisa.
} 
está situada na cidade de Nilópolis, na Região Metropolitana do Rio de Janeiro, e também recebe educandos de camadas populares moradores de comunidades próximas à unidade escolar. O município do Rio de Janeiro - em especial a Zona Sul, incluindo as favelas ali presentes - possuem percentuais pequenos de evangélicos pentecostais quando comparada com as cidades da Região Metropolitana, como Nilópolis. Tendo em vista que este é o grupo religioso que mais apresenta resistência à visão científica sobre a origem da vida e a evolução dos seres vivos, a possibilidade de explorar e comparar dois contextos em que sua presença é distinta foi considerado de grande pertinência para a pesquisa.

\begin{tabular}{lr}
\hline Religião & $\%$ \\
\hline Católica Apostólica Romana & 51,1 \\
\hline Evangélica de Origem Pentecostal & 12,6 \\
\hline Sem religião & 12,5 \\
\hline Evangélica Não Determinada & 7,0 \\
\hline Espírita & 5,9 \\
\hline Outras Religiosidades & 4,1 \\
\hline Evangélica de Missão & 3,8 \\
\hline Umbanda e Candomblé & 1,3 \\
\hline Agnóstico e Ateu & 1,1 \\
\hline Não Determinada/ Múltiplo Pertencimento & 0,4 \\
\hline Não sabiam/ Sem Declaração & 0,2 \\
\hline Total & 100,0 \\
\hline
\end{tabular}

Tabela 1.2: Distribuição percentual da população residente no município do Rio de Janeiro segundo os grupos de religião (Fonte: Censo 2010).

\begin{tabular}{lr}
\hline Religião & $\%$ \\
\hline Católica Apostólica Romana & 39,4 \\
\hline Evangélico Pentecostal & 17,2 \\
Sem religião & 16,9 \\
Evangélico Não Determinado & 11,3 \\
Evangélico de Missão & 4,6 \\
Outras religiosidades & 4,3 \\
Espírita & 3,8 \\
Umbanda e candomblé & 1,5 \\
Ateu e agnóstico & 0,5 \\
Não determinada e múltiplo pertencimento & 0,4 \\
Não sabiam/Sem declaração & 0,1 \\
Total & 100,0 \\
\hline
\end{tabular}

Tabela 1.3: Distribuição percentual da população residente no município de Nilópolis segundo os grupos de religião (Fonte: Censo 2010).

\footnotetext{
${ }^{3}$ Nomenclatura usada pelo IBGE a partir do Censo de 2000 para definir o grupo formado por denominações evangélicas tradicionais (batistas, adventistas, presbiterianos, entre outros) (JACOB, et al., 2003).
} 
Ao compararmos as duas tabelas apresentadas, vemos que a presença evangélica em Nilópolis é proporcionalmente maior do que no Rio de Janeiro. A cidade da Baixada Fluminense possuía, em 2010, 17,2\% pentecostais contra $12,6 \%$ da capital, $11,3 \%$ de evangélicos não determinados contra 7,0\% e 4,6\% de missão contra $3,8 \%$. Somados os três grupos, chega-se a marca de $33,1 \%$ contra 23,4\%. É interessante notar, ainda, a diferença no número de católicos, 39,4\% em Nilópolis contra 51,1\% no Rio de Janeiro e a significativa presença daqueles que se declaram sem religião em ambas as cidades - 16,9\% em Nilópolis e 12,5\% no Rio. Tal cenário vem sendo verificado ao longo das últimas décadas também a nível nacional e em outros estados e por outras pesquisas (JACOB et al., 2003, 2013; PIERUCCI, 2013).

Dentre as estratégias de pesquisa possíveis, foram selecionadas para este trabalho, além da revisão de bibliografia sobre os temas centrais, três procedimentos metodológicos principais: (1) questionários, (2) observações e (3) entrevistas semiestruturadas.

Por meio do questionário utilizado para a pesquisa (Apêndice 1), procuramos obter um perfil mais amplo dos sujeitos investigados, tornando possível comparar os conteúdos das entrevistas e observações com as concepções presentes entre os estudantes. Uma versão piloto do questionário foi aplicada em caráter de teste a duas das turmas de primeiro ano do Colégio Guarani ( $\left.n_{\mathrm{PT}}=48\right)$, as quais não foram incluídas na base de dados final da pesquisa. Após correções de digitação, o questionário definitivo foi aplicado a todas as turmas do $1^{\circ}$ ano do ensino médio restantes do Colégio Guarani e a todas do Colégio Passaredo, entre setembro e outubro de 2014, quando os alunos(as) já haviam assistido a todas as aulas de evolução e origem da vida.

O questionário possui cinco partes. A primeira é composta por 12 afirmações sobre as quais o respondente deve fazer sua avaliação seguindo uma escala de Likert. Essa seção consiste em uma livre adaptação do Measure of Acceptance of the Theory of Evolution (MATE). Elaborado por Rutledge e Warden (1999) para estudar a aceitação da teoria evolutiva por professores de ensino médio, o MATE é um dos instrumentos mais utilizados em pesquisas nessa temática. Dado que o questionário original foi pensado para professores de biologia do ensino médio, optamos por excluir algumas questões que tratavam de temas específicos de pesquisa em evolução e simplificamos o enunciado de outros 
itens, a fim de facilitar sua compreensão pelos estudantes. Além disso, seguimos as críticas de Smith (2010a) de que o MATE ao optar pela forma de responder "concordo" ou "discordo" não estaria captando o sentido de "acreditar" ou "não acreditar" a que se propõe. Dessa maneira, modificamos nossa escala, tendo em vista tais considerações, para graduações que vão de "não acredita" a "acredita fortemente".

A segunda parte é composta pelas questões 13 a 24, relacionadas à compreensão de conteúdos relacionados à teoria evolutiva. Essas questões foram desenvolvidas por Rutledge e Warden (2000)também para professores. Assim, tal como na seção anterior, adaptamo-las para facilitar seu entendimento por parte dos estudantes. Estas perguntas abordam temas como as teorias darwiniana e lamarckista, evidências evolutivas, ancestralidade comum entre outros. O objetivo desta seção é fornecer dados para avaliar se há diferenças na compreensão da teoria evolutiva entre estudantes de perfis religiosos distintos e se há relação entre a compreensão e a aceitação da evolução, baseada nos dados da primeira parte.

A terceira parte, composta pelas questões 25 a 29 foi adaptada da versão em português do Índice de Religiosidade da Universidade de Duke, ou DUREL na sigla em inglês. Esse instrumento de coleta de dados foi elaborado por Koenig e sua equipe (KOENIG; BÜSSING, 2010; KOENIG; PARKERSON G.R.; MEADOR, 1997) para ser utilizado em pesquisas da área de saúde. Já foi utilizado em mais de 100 artigos científicos e traduzido para dez línguas, inclusive o português, elaborado por Moreira-Almeida et al(2008), a partir do qual fizemos livre adaptação. Embora estejamos propondo seu uso para uma área distinta da que foi concebido, o DUREL mostra-se interessante por tratar de diferentes dimensões de religiosidade de maneira sucinta. Certamente é preciso reconhecer que a experiência e a história de cada indivíduo com relação às suas crenças são muito mais complexas do que essas cinco questões conseguem captar. Contudo, para uma análise do grupo de estudantes e não de cada um individualmente, esta ferramenta nos auxiliou satisfatoriamente. Além disso, o DUREL foi elaborado para o contexto norte-americano, o que poderia trazer dificuldades. Porém, devese ressaltar que tanto nos EUA quanto no Brasil, a maioria religiosa é cristã, o que pode vir a diminuir possíveis limitações e possibilitar uma utilização relativamente segura 
Os três primeiros itens desse bloco, em formato de escala de Likert, abrangem a religiosidade interna, que seria o grau de compromisso e motivação religiosa pessoal. Já a segunda questão - "com que frequência você vai a uma igreja, templo ou outro encontro religioso?" - visa a abordar a religiosidade organizacional, isto é, atividades religiosas públicas, tais como a participação em serviços religiosos ou a participação em outros grupos relacionados à atividade religiosa (grupos de oração, grupos de estudos de textos sagrados). O último ponto da seção - "que frequência você dedica o seu tempo a atividades religiosas individuais, como preces, rezas, meditações, leitura da bíblia ou de outros textos religiosos?" - trata da religiosidade não-organizacional, ou seja, atividades religiosas realizadas no âmbito privado, tais como orações, estudo de textos sagrados, assistência a programas de TV ou rádio religiosos etc.

Em seguida, as questões 30 a 33 tratam da declaração religiosa dos estudantes de forma mais direta. A questão 30 visa a determinar a religião do(a) estudante. Ao contrário do Censo Demográfico do IBGE, optamos por usar um modelo de respostas fechadas, uma vez que, como Mafra (2013) aponta, o formato de questão aberta do Censo leva a dificuldades de categorizar os participantes devido às múltiplas respostas possíveis na autodeclaração. Com relação à categoria "evangélico", optamos por não apresentá-la como "pentecostais", "de missão" ou "indeterminado" já que tais conceitos não estão tão presentes no senso comum e, dessa maneira, possivelmente não seriam compreendidos pelos estudantes. Já a questão 31 procura identificar qual a igreja/templo/terreiro/centro que o respondente frequenta, algo que se justifica pela grande diversidade de instituições que se declaram evangélicas. Com isso queremos ter maior precisão para distinguir estudantes evangélicos de origem pentecostal, de missão e não determinados. Em seguida, a pergunta 32 pede ao participante que identifique se participa de algum grupo ligado à sua religião. Isso nos permitirá ter mais uma informação sobre a aderência dos estudantes às suas religiões. Fechando este bloco, a questão 33 visa captar se os estudantes possuem práticas de duplo-pertencimento religioso, algo que é comum em nosso país, mas que o Censo também tem dificuldade de determinar (MAFRA, 2013). Essas quatro questões foram colocadas ao final do bloco seguindo o alerta de Cardoso (2004) de que perguntar a religião do sujeito ao início do questionário poderia fazer com que ele se sentisse "obrigado" a ter um determinado padrão de respostas 
para estar de acordo com as orientações da instituição religiosa declarada como de seu pertencimento.

A última parte do questionário utilizado nesta pesquisa abrange as questões 34 a 72 e foram adaptadas a partir do questionário socioeconômico do SAEB para alunos do $3^{\circ}$ ano do ensino médio. O objetivo desta seção é fornecer dados para a compreensão do contexto socioeconômico dos estudantes que auxiliem na interpretação e análise da aceitação e compreensão da teoria evolutiva. Há, ainda, questões sobre atitudes e ideias sobre a disciplina escolar de biologia, a rotina de estudos dos alunos e seus planos para o futuro após a conclusão do ensino médio.

Uma vez que a motivação da principal questão de pesquisa era o contato direto com as situações de sala de aula, foram realizadas observações das aulas de biologia, das salas de professores e de outros ambientes das duas escolas ao longo de doze meses no Colégio Guarani (de setembro de 2013 a outubro de 2014) e de nove meses (de fevereiro a outubro de 2014) no Colégio Passaredo. Tal diferença nos tempos de observação se deu em função do contato ter sido estabelecido primeiramente na escola carioca e posteriormente na nilopolitana. A fim de manter a coerência entre as turmas e estudantes participantes da pesquisa, o período de observações realizado em 2013 serviu de experiência piloto e de tempo de aclimatação em relação ao ambiente escolar e à estrutura organizacional do sistema de educação estadual. Assim, os dados principais para a pesquisa foram coletados ao longo de 2014.

Com relação às observações do campo, Tura (2003) afirma que estas permitem a aproximação com o acontecer social e a análise do ponto de vista dos atores. No entanto, seu objetivo não deve ser a mera descrição da realidade, mas também a interpretação do que foi observado. O trabalho de análise e organização dos dados deve ser constante e caminhar juntamente com a pesquisa para que tendências e novos questionamentos não se percam ao longo do caminho (BEAUD; WEBER, 2007). Nesse sentido, utilizamos essa metodologia como forma de nos familiarizar com o campo e estivemos atentos a diferentes aspectos que pudessem estar relacionados direta ou indiretamente às especificidades que a presença de alunos pentecostais e neopentecostais representa para o ensino de evolução. Como explicitado anteriormente, dada a escassez de pesquisas nessa temática que utilizam observações do cotidiano escolar como estratégia 
metodológica de pesquisa, ela ocupou lugar central em nosso estudo, pois acreditamos que possa revelar características da realidade que outras metodologias utilizadas não são capazes. Ao contrário de uma entrevista ou de um questionário nos quais os sujeitos teriam mais tempo para reflexão sobre os temas da pesquisa, a dinamicidade da sala de aula faz com que reações mais espontâneas ali se desenvolvam e, por meio de observações, tentamos ter contato com elas. Além disso, essa metodologia serviu de fomento para a elaboração dos roteiros de entrevista tanto de alunos(as), quanto professores/as. Procuramos observar o ambiente escolar como um todo (sala dos professores, pátios, bibliotecas, salas da direção, etc.), porém, a prioridade foram as aulas de biologia. Nesse sentido, dedicamos a maior parte do tempo do trabalho de campo às situações de sala de aula, tentando, contudo, buscar compreender o contexto mais amplo em que elas estão inseridas. No entanto, vale destacar que a observação também apresenta limitações, uma vez que a própria presença do pesquisador já interfere no contexto observado e, além disso, o que é observado está condicionado pelo olhar do pesquisador, sendo impossível captar toda a riqueza da vida social.

Tendo em vista a complexidade do tema, realizamos ainda entrevistas semiestruturadas com os/as sete professores/as de biologia das turmas observadas do primeiro ano de ambas as escolas e vinte estudantes, sendo dez de cada escola. Os roteiros de entrevista podem ser vistos nos Anexos 2 e 3, respectivamente. As entrevistas com os professores tiveram duração entre uma hora e uma hora e vinte minutos, ocorreram nas próprias escolas, após seus horários de aula, à exceção de $\mathrm{P} 4$, cuja entrevista foi realizada em sua residência, antes de seu horário de trabalho. As entrevistas com os alunos ocorreram nos próprios colégios e, em sua maioria, durante o recreio. Esta foi a melhor escolha dentro de nossas possibilidades, já que era da preferência dos participantes que não os entrevistássemos fora da jornada escolar. No entanto, isso nos trouxe uma grande limitação de tempo, já que o recreio durava em torno de 20 minutos. A seleção dos estudantes para as entrevistas não foi randômica, mas sim baseada nas observações de sala de aula. Uma lista foi oferecida aos estudantes para que aqueles que gostariam de participar colocassem seus dados para contato. Foram escolhidos alunos que, preferencialmente, participaram ativamente das aulas, principalmente daquelas relacionadas à evolução e origem da vida, segundo os 
nossos registros das observações. Foram distribuídos termos de consentimento para os responsáveis, para os próprios estudantes e para os professores.

Quanto às entrevistas, Zago (2003, p. 301) afirma que elas expressam:

Realidades, sentimentos e cumplicidades que um instrumento com respostas estandardizadas poderia ocultar, evidenciando a infundada neutralidade científica daquele que pesquisa. $\mathrm{O}$ encontro com um interlocutor exterior ao universo social do entrevistado representa, em vários casos, a oportunidade de este ser ouvido e poder falar de questões sociais que lhe concernem diretamente.

Assim, optamos por realizar entrevistas semiestruturadas, pois isso nos permitiu ter, simultaneamente, clareza dos objetivos e flexibilidade para captar e explorar questões manifestadas pelos sujeitos de pesquisa não previstas anteriormente. Neste sentido, foram definidos temas, e no interior destes, questões mais específicas para auxiliar na definição mais precisa da problemática, hierarquizando o que é central e o que é periférico na investigação, como sugerido por Zago (2003).

Além das entrevistas semiestruturadas, conversas não-estruturadas com membros da direção e da coordenação das escolas foram conduzidas em diversos momentos da pesquisa. Seu objetivo era, principalmente, esclarecer dúvidas pontuais sobre o funcionamento da instituição de ensino e do sistema estadual de educação. Pelo seu caráter espontâneo, não foram gravadas para não causar embaraço aos interlocutores, mas, tão logo possível, notas no caderno de campo foram tomadas. Vale frisar que todas as pessoas com quem lidamos dessa maneira durante a pesquisa tinham conhecimento de nossas motivações.

Dessa forma, buscamos ouvir alguns informantes importantes relacionados à presença religiosa e aos possíveis conflitos que ocorrem na escola. A direção, por ter fundamental importância no discurso oficial da instituição, marcando as orientações gerais do projeto pedagógico, os/as professores/as de biologia, por serem responsáveis pelo ensino de evolução e os estudantes por serem o centro do processo educativo.

Ressalta-se, ainda, que o uso de diferentes metodologias é oportuno no sentido de que uma pode fornecer elementos que a outra não conseguiria. Assim, tentamos o cruzamento dos dados sempre que possível, de modo a aumentar a sua validade e confiabilidade.

Com relação à análise dos dados, adotamos a análise de conteúdo como principal ferramenta para os dados qualitativos. As anotações de caderno de 
campo foram expandidas e detalhadas em momento posterior ao da coleta dos dados e as entrevistas foram transcritas integralmente e revistas diversas vezes a fim de assegurar, ao máximo, sua precisão. Seguindo as orientações de Braun e Clarke (BRAUN; CLARKE, 2006), os materiais foram lidos repetidas vezes para que fosse aumentada a familiaridade com eles. Em seguida, foram codificados utilizando-se o software de análise de dados qualitativos Atlas.ti versão 7 . Na etapa seguinte, os códigos gerados foram organizados em temas mais abrangentes que foram checados em relação aos diferentes trechos codificados e ao conjunto de dados como um todo. Posteriormente, os temas foram analisados a fim de compreender sua relação com a "história" contada nos dados - o perfil dos sujeitos de pesquisa, suas concepções e reflexões acerca da temática (a lista de temas e códigos utilizados na análise pode ser encontrada no Apêndice 9). Finalmente, foi elaborado o presente texto, destacando-se os principais temas, trechos que os exemplificam, sua relação com a pergunta da pesquisa e com a literatura da área. Em relação aos dados quantitativos, utilizamos o software SPSS em sua versão 20, a fim de organizá-los da maneira que pudéssemos melhor descrever e compreender os sujeitos de pesquisa e suas percepções sobre os temas em estudo.

\section{6}

\section{Estrutura da tese}

A presente pesquisa de doutorado está organizada em sete capítulos, além de referências e anexos. Neste primeiro capítulo, optamos por fazer uma breve introdução da nossa temática e expor os elementos que acreditamos justificar a investigação, questões centrais de pesquisa, seus objetivos, hipóteses, escolhas metodológicas e características gerais.

No segundo capítulo, procuramos estabelecer diálogos com a literatura da área, explicitando os pressupostos da pesquisa e nossas perspectivas de análise. Neste sentido, serão apresentados e discutidos temas como a importância da evolução para as disciplinas acadêmica e escolar de biologia, o cenário religioso brasileiro atual, algumas concepções acerca da interculturalidade e apontamentos sobre o trabalho de Habermas como nosso referencial teórico analítico. O ensino 
de evolução se mostra bastante complexo, e desafiante, tendo em vista o forte crescimento de denominações que demonstram resistência a esta temática. Defendemos que a evolução é um dos eixos centrais da biologia e que seu ensino deve ser pautado pela sua compreensão e não pela mudança de crença do estudante. Nossa intenção é relacionar a importância do ensino de evolução, as prováveis tensões com um cenário religioso de forte presença pentecostal e as possibilidades de análise numa perspectiva intercultural.

No terceiro capítulo, descrevemos com maior profundidade o campo e os sujeitos de nossa pesquisa. Apresentamos alguns dados iniciais obtidos através de nosso questionário, das entrevistas e observações realizadas. Procuramos oferecer as linhas gerais dos contextos pesquisados, ressaltando, principalmente, os aspectos relacionados à presença religiosa nas escolas e como os participantes se relacionam com a religião.

No quarto capítulo, realizamos a análise dos dados relativos às concepções dos professores pesquisados sobre criacionismo e evolução. Verificamos que, em sua maioria, possuem religião e elaboram maneiras distintas e bastante complexas para conciliar suas crenças religiosas e seus conhecimentos em biologia. Este estudo de suas concepções pessoais serve como chave para analisar como esses professores desenvolvem sua prática pedagógica e seu relacionamento com seus estudantes.

Já no quinto capítulo, analisamos as concepções de evolução e criacionismo dos estudantes na forma de dados qualitativos, entrevistas e observações de campo, e quantitativos, questionários aplicados. Buscamos identificar as semelhanças e diferenças entre os pensamentos dos discentes, com especial atenção ao grupo religioso ao qual pertencem. Elaboramos, ainda, índices para o estudo da aceitação e entendimento da teoria evolutiva e dimensões da religiosidade. Estudamos esses indicadores comparativamente entre os grupos de religião e as escolas, além de analisar possíveis correlações entre eles e outros fatores pesquisados, como atitudes e concepções sobre a disciplina de biologia.

No sexto capítulo, abordamos mais diretamente as aulas observadas, explorando, principalmente, os momentos em que os docentes tratavam do criacionismo e crenças religiosas. É possível perceber que foram escassos os conflitos explícitos, isto é, em que um ou mais estudantes se posicionavam frontalmente defendendo uma posição distinta daquela apresentada pelo professor. 
As posturas dos docentes também variaram: por exemplo, enquanto um dos professores menosprezou a crença religiosa de uma estudante, outra professora afirmou que ciência e religião se encontram. Ao comparamos suas práticas pedagógicas com suas concepções pessoais, percebemos que há muitas semelhanças. Além disso, ao compararmos as posturas dos estudantes com suas ideias e crenças, evidencia-se que muitos optam por não demonstrar suas discordâncias com o que está sendo ensinado, ainda que estejam em profundo desacordo.

No sétimo e último capítulo, apresentamos as conclusões de nosso trabalho e discutimos a validade das hipóteses levantadas, bem como em que medida nossos objetivos foram alcançados. 


\section{2.}

\section{Diálogos com a teoria}

No presente capítulo, aprofundamos os principais referenciais teóricos de nossa investigação, procurando explicitar de que maneira podem contribuir para o estudo das relações entre o ensino de evolução e a religião dos estudantes pesquisados. Apresentamos e discutimos elementos da produção atual relacionada (i) à importância da evolução para a biologia e os objetivos do ensino de ciências, (ii) ao pentecostalismo, ao neopentecostalismo e ao cenário religioso brasileiro e (iii) a concepções sobre interculturalidade. Por fim, a partir de uma leitura específica sobre a obra de Habermas, desenvolvemos um modelo para a análise e promoção do ensino de evolução que respeite as crenças religiosas dos estudantes.

\section{1.}

\section{A importância da evolução para a biologia e os objetivos do ensino de ciências}

Embora a teoria evolutiva através da seleção natural tenha sido alvo de muitas controvérsias desde sua proposição por Darwin e Wallace (BROOKE, 1991; MEYER; EL-HANI, 2005), atualmente ela é considerada um eixo central para a biologia tanto como disciplina acadêmica(MAYR, 1982), quanto disciplina escolar (SANDERS; NGXOLA, 2009; TIDON; LEWONTIN, 2004). Esta concepção pode ser encontrada nos Parâmetros Curriculares Nacionais do Ensino Médio (BRASIL, 1998) e fica ainda mais explícita nas Orientações Curriculares para o Ensino Médio (OCEM):

Um tema de importância central no ensino de Biologia é a origem e evolução da vida. Conceitos relativos a esse assunto são tão importantes que devem compor não apenas um bloco de conteúdos tratados em algumas aulas, mas constituir uma linha orientadora das discussões de todos os outros temas. (...) A presença do tema origem e evolução da vida ao longo de diferentes conteúdos não representa a diluição do tema evolução, mas sim a sua articulação com outros assuntos, como elemento central e unificador no estudo da biologia.(BRASIL, 2006, p. 22). 
Apesar de sua notória importância, diversos estudos apontam que a teoria evolutiva é um tópico que apresenta dificuldades no processo de ensinoaprendizagem. Seja nos livros didáticos (ALMEIDA; FALCÃO, 2005, 2010), nas concepções de professores (CARVALHO; CLÉMENT; LYON, 2007; OLEQUES; BARTHOLOMEI; BOER, 2011; TEIXEIRA; ANDRADE, 2014; TEIXEIRA, 2012), de licenciandos em biologia (DORVILLÉ; SELLES, 2009; EL-HANI; SEPULVEDA, 2010) ou de estudantes da escola básica (SANTOS, 2002).Tópicos como as teorias de Lamarck e Darwin, o caráter não-teleológico da evolução, o conceito de adaptação, dentre outros, são alguns dos conteúdos que se mostram de difícil compreensão e em diferentes níveis de ensino.

Para além das dificuldades acima indicadas, há ainda pesquisas sobre o complexo relacionamento entre o ensino de evolução e crenças religiosas criacionistas. Rutledge e Warden (2000) afirmam que a oposição de grupos religiosos e as crenças religiosas de professores de biologia estão entre os fatores que mais influenciam o debate entre evolução e criacionismo nas escolas norteamericanas. Os pesquisadores analisam as relações entre o entendimento e aceitação da teoria evolutiva e o conhecimento acerca da natureza da ciência por parte de professores de escolas públicas de ensino médio em Indiana, nos EUA. Eles apontam que há uma relação positiva estatisticamente significativa entre essas variáveis, isto é, os professores que possuíam maior conhecimento de evolução também eram os que mais a aceitavam e mais entendiam sobre a natureza da ciência. Inversamente, aqueles que menos entendiam a teoria evolutiva eram os que menos a aceitavam e que menos conheciam a natureza da ciência. Resultados semelhantes foram encontrados em outros estudos com professores nos EUA (RUTLEDGE; MITCHELL, 2002; TRANI, 2004) e também no Brasil (COIMBRA; SILVA, 2007; OLEQUES; BARTHOLOMEI; BOER, 2011), nos quais as concepções religiosas também surgem como um dos fatores marcantes entre aqueles professores que apresentam uma baixa aceitação da teoria evolutiva.

Especificamente acerca das relações entre evolução biológica e crenças religiosas, outras pesquisas mostram que quanto maior o caráter fundamentalista da fé professada, menor a aceitação da evolução biológica (SMITH, 2010a). Em pesquisa com estudantes protestantes do último ano de um curso de licenciatura em ciências biológicas, El-Hani e Sepúlveda (2010) encontraram dois grupos 
distintos: (1) um que possuía visão mais compatível com a ciência, estabelecendo diálogo constante entre as ideias científicas, visões teísticas sobre criação divina e a ação permanente de Deus sobre o mundo natural; (2) e outro que evitava deliberadamente se apropriar do discurso científico, uma vez que o concebiam como conflituoso com suas visões religiosas. Esses autores destacam que os alunos do segundo grupo tinham visões religiosas mais fundamentalistas se comparados com os do primeiro e que isto está correlacionado a uma busca por certezas, algo que não encontram no conhecimento científico. De forma semelhante, em minha dissertação de mestrado (TEIXEIRA, 2012), metade dos professores entrevistados relatou já ter vivenciado situações de conflito em sala de aula, principalmente com estudantes evangélicos pentecostais e neopentecostais ${ }^{4}$. A rejeição por parte de fundamentalistas também foi pesquisada entre mulçumanos (BOUJAOUDE et al., 2011) mostrando que, embora o debate entre criacionismo e evolução seja mais tipicamente abordado em contextos cristãos (ENGLER, 2007; NUMBERS, 2006; SCOTT, 2009), também se faz presente em outras religiões.

Além disso, é interessante notar que El-Hani e Sepúlveda(EL-HANI; SEPULVEDA, 2010) afirmam que os estudantes de crenças fundamentalistas praticam o que Cobern (COBERN, 1996) chama de "apartheid cognitivo", ou seja, colocam a ciência em um "compartimento" separado por não se encaixar na maneira como costumam pensar seu cotidiano, marcadamente dominado por suas crenças religiosas. Isto permite que eles não sintam suas crenças ameaçadas e tenham sucesso acadêmico, pois conseguem responder às questões colocadas pelos professores em suas avaliações. Tal fato também já foi reportado em outras pesquisas (ALMEIDA, 2012; BLACKWELL; POWELL; DUKES, 2003; FONSECA, 2005) $)^{5}$.

Em consonância comesses achados, faz sentido questionar o que significam "entender" e "acreditar" e qual seria o objetivo do ensino de evolução.

\footnotetext{
${ }^{4}$ Esses conflitos não eram homogêneos. Uma professora relatou que seus alunos tratavam a teoria da evolução com desdém e deboche, enquanto outra afirmou que um de seus alunos ficou de pé e gritou que aquele conteúdo era mentira e que ela não poderia ensiná-lo.

5 Há estudos de fundamentação cognitiva-psicológica que indicariam que determinados fatores adotados pelas religiões (essencialismo, teleologia e intuição de que há um criador) seriam intuitivos, o que dificultaria a aceitação da evolução, pois a teoria evolutiva rejeita essas três premissas (BLANCKE et al., 2011).
} 
Cobern (1994; 2000)critica o que chama de "cientificismo" o conhecimento científico parte de pressupostos racionais, objetivamente derivado da razão e é universalmente aceito. Assim, caberia apenas "entendê-lo" e não "acreditar" nele. Por outro lado, uma crença estaria ligada a uma dimensão irracional, necessária quando se lida com aquilo que é visto como sagrado. Além disso, seria subjetiva e uma questão de opinião privada. Nesse sentido, Cobern (2000)afirma que negar a razão das crenças leva a dois problemas em sala de aula: (i) prejulgar se uma proposição é um conhecimento ou uma crença diminui a gama de assuntos que podem ser discutidos em sala de aula; (ii) assumir tacitamente que entender leva à aceitação; analogamente, se um aluno não aceita uma dada proposição - vista pelo professor como a correta - ele não entendeu aquela proposição. Cobern(1994) também defende que não há uma diferença inquestionável do ponto de vista epistêmico entre conhecer e acreditar. De um ponto de vista prático, ambos representam o que alguém tem razão para acreditar como verdadeiro ou válido. Para Cobern (1994), o ensino de evolução deve partir de um diálogo em sala de aula baseado em materiais sobre a história cultural do darwinismo e de forma alguma ter por objetivo o "doutrinamento" em uma perspectiva de cientificismo.

Smith e Siegel (SMITH; SIEGEL, 2004)defendem que acreditar normalmente - mas nem sempre - segue o entendimento. Argumentam que entender possui quatro dimensões: conectividade (compreender as relações entre as ideias que baseiam uma dada proposição); fazer sentido (atribuir um significado àquela proposição); aplicação (ser capaz de aplicar tal proposição em um contexto acadêmico ou não acadêmico); justificação (envolve a apreensão de algumas razões que justificam aquela proposição).

Em crítica a Cobern (2000), Smith e Siegel (SMITH; SIEGEL, 2004)afirmam que o fato de alguém acreditar que uma proposição é verdadeira não faz com que essa proposição seja verdadeira. Além disso, embora concordem com a afirmação de que pressupostos científicos não possam ser provados empiricamente, discordam de que eles não possam ser sustentados racionalmente.

Smith e Siegel (SMITH; SIEGEL, 2004)sugerem, tal qual Cobern (1994), que o objetivo do ensino de evolução seja o conhecimento e o entendimento e não

\footnotetext{
6 "Scientism" no original.
} 
uma mudança de crença dos estudantes. No caso de estudantes que não demonstram mudança de crença, o ideal seria explorar tal situação para debater as diferenças entre o pensamento científico e outras formas de produção de conhecimento, bem como que uma teoria, tal qual a evolução, é a melhor explicação do ponto de vista científico para aquele determinado fenômeno. Outros autores também têm destacado o entendimento, mais do que a mudança de crença, como o objetivo do ensino de evolução (DORVILLÉ; SELLES, 2009; EL-HANI; SEPULVEDA, 2010; REISS, 2008, 2009).

É interessante notar que diferentes abordagens multiculturais ${ }^{7}$ têm sido propostas para se discutir o currículo e o ensino de biologia. Segundo El-Hani e Mortimer (2007), isso se deve a: (i) surgimento do construtivismo como uma forte tendência no ensino de ciências; (ii) mudança nos estudos sobre currículo, mais focados em processos históricos de construção dos conhecimentos escolares; (iii) atitude mais crítica de diversos grupos sociais e culturais em relação à ciência ocidental moderna; (iv) crítica da postura do ocidente em relação a outras formas de conhecimento, por programas de pesquisa como o pós-modernismo e o multiculturalismo. A partir disso, alguns questionamentos podem ser feitos, tais como: a cultura de quem estamos ensinando quando ensinamos ciências? A ciência é um conteúdo culturalmente neutro e que possa ser ensinado sem seus contextos mais profundos de significado? Que critérios devemos usar para definir o que conta e o que não conta como ciência? A ciência é universal? Se sim, como entender a pretensão da ciência em ser universal? Se não, se a ciência pode ser relativa, como defender seu caráter experimental e suas concepções de verificabilidade e aprimoramento?

Cobern e Loving (2001) procuram responder esses questionamentos de modo a evitar tanto uma posição relativista, na qual todas as formas de conhecimento poderiam ser consideradas como "cientificamente válidas", quanto uma postura cientificista, na qual a ciência seria vista como superior a todas as outras formas de conhecimento. Nesse sentido, defendem que incluir outras formas de conhecimento, como os conhecimentos ecológicos tradicionais, sob a denominação de ciência, faria com que elas enfrentassem consequências

\footnotetext{
7 Embora os pesquisadores em ensino de ciências aqui utilizados utilizem o termo "multiculturalismo", suas visões não nos parecem incompatíveis com a concepção de interculturalidade que adotamos e que explicitaremos mais à frente.
} 
negativas. Elas perderiam suas especificidades e tornar-se-iam meros símbolos de uma inclusão cultural e não propriamente participantes válidos do discurso da ciência.

Além disso, Cobern e Loving (2001) diferem a universalidade da ciência e o cientificismo. Em sua visão, o problema não seria a capacidade de produção de conhecimentos altamente eficazes sobre os fenômenos naturais, mas sim o uso da ciência para dominar a opinião pública como se todos os outros discursos fossem inferiores. Nesse sentido, os autores sugerem que o ensino de ciências esteja pautado em um pluralismo epistemológico, no qual os conhecimentos tradicionais estejam presentes, porém tornando claras suas diferenças para a ciência. Estabelecer essas fronteiras não implica em diminuir a importância de outras formas de conhecimento, o que também é defendido por outros autores (ELHANI; MORTIMER, 2007; SOUTHERLAND, 2000).

É interessante notar que mesmo entre religiões de características fundamentalistas, há certos pontos de aceitação da teoria evolutiva. Como Smith(2010a)e Oliveira e Bizzo (2011) afirmam, estudantes que professam uma fé religiosa com esse perfil rejeitam mais fortemente aspectos relacionados à idade da Terra e, principalmente, à evolução humana do que a existência e validade de fósseis e processos de microevolução. Embora a maior parte dos estudos sobre essa temática se pautem em diferenças epistemológicas entre criacionismo e evolução - e, em um sentido mais amplo, entre ciência e religião - Evans e Evans (2008) e Evans (2011) propõem que se estude essa relação em uma perspectiva de conflito moral. Em suas pesquisas, esses autores mostram que pessoas que professam uma fé religiosa - inclusive fundamentalista - tendem a rejeitar a visão científica apenas em assuntos em que está entre em conflito com suas concepções morais baseadas na visão religiosa e não em tópicos em que não há essa divergência. Assim, mais do que o método científico, ou a natureza da ciência, seriam rejeitadas as implicações morais da visão científica em assuntos como a teoria da evolução e pesquisas com células tronco embrionárias.

Nesse sentido, partilhamos da visão exposta por Cobern e Loving (2001) e, tendo em vista as considerações feitas por Evans e Evans (2008) e Evans (2011) poder-se-ia repensar a rejeição de estudantes - e professores - que professam uma fé religiosa de características fundamentalistas. Cabe questionar se esses conflitos seriam mais de fundo moral do que epistemológico, como é tratado na maior parte 
das vezes. Aprofundaremos esse argumento ao relacioná-lo com as características das religiões pentecostais e neopentecostais no próximo tópico.

\section{2.}

\section{Evangélicos pentecostais e neopentecostais: crescimento características}

Nos últimos 30 anos, o cenário religioso brasileiro vem passando por transformações marcantes. As religiões chamadas de evangélicas pentecostais e neopentecostais vêm crescendo em ritmo acelerado e conquistando mais e mais fiéis (MARIANO, 1999). Paralelamente, observa-se um decréscimo da população católica que, embora ainda seja o maior grupo religioso do país, já não é mais tão hegemônico como até a década de 1980.

Cabe ainda destacar, o aumento da população que se declara sem religião.

Essas pessoas não são ateias ou agnósticas, mas acreditam em uma entidade transcendental, por exemplo: deus, deuses, energias, entre outros. Contudo, não estão filiadas a nenhuma religião institucionalizada. Assim, ainda que o censo populacional do IBGE (2012) e pesquisadores (PIERUCCI, 2004) os tratem como um todo definido por "sem religião", isso não significa que sejam um grupo homogêneo. A tabela a seguir evidencia essas mudanças:

\begin{tabular}{rrrrrrr}
\hline Anos & Católicos & $\begin{array}{r}\text { Evangélicos } \\
\text { de missão }\end{array}$ & $\begin{array}{r}\text { Evangélicos } \\
\text { pentecostais }\end{array}$ & $\begin{array}{r}\text { Evangélicos } \\
\text { não } \\
\text { determinados }\end{array}$ & Outros & $\begin{array}{r}\text { Sem } \\
\text { religião }\end{array}$ \\
\hline $\mathbf{1 9 8 0}$ & $89,0 \%$ & $3,4 \%$ & $3,2 \%$ & - & $2,8 \%$ & $1,6 \%$ \\
$\mathbf{1 9 9 1}$ & $83,3 \%$ & $3,0 \%$ & $5,6 \%$ & $0,4 \%$ & $3,0 \%$ & $4,7 \%$ \\
$\mathbf{2 0 0 0}$ & $73,6 \%$ & $4,1 \%$ & $10,4 \%$ & $0,3 \%$ & $4,3 \%$ & $7,4 \%$ \\
\hline $\mathbf{2 0 1 0}$ & $65,0 \%$ & $4,0 \%$ & $13,3 \%$ & $4,8 \%$ & $4,8 \%$ & $8,0 \%$ \\
\hline
\end{tabular}

Tabela 2.1: População total e grupos religiosos. Fonte: Jacob, Hees et al. (2013 IBGE, Censos Demográficos de 1980, 1991, 2000 e 2010.

Em 1980, os católicos representavam 89\% da população brasileira, os evangélicos de missão $3,4 \%$, os evangélicos pentecostais ${ }^{8} 3,2 \%$ e os sem religião $1,6 \%$. Nas décadas seguintes, percebe-se uma acentuada queda do número de católicos (em 1991 eram 83,3\%, em 2000, 73,6\%). Em 2010, não só houve uma queda percentual do total de católicos (agora com 65\%), mas também, pela

\footnotetext{
${ }^{8}$ Neste ponto estamos adotando a classificação do IBGE. Mais adiante explicitaremos com mais detalhes porque os sujeitos de nossa pesquisa serão considerados, prioritariamente, evangélicos neopentecostais.
} 
primeira vez, em números absolutos (de cerca de 1 milhão de fiéis). $\mathrm{O}$ número de evangélicos pentecostais cresce a um ritmo acelerado (5,6\% em 1991, 10,4\% em 2000 e 13,3\% em 2010). Os evangélicos não determinados ${ }^{9}$, por sua vez, apresentaram grande crescimento na última década (de 0,3\% em 2000 para 4,8\% em 2010). Já os sem religião, também vêm crescendo nas últimas décadas, porém em um ritmo menos intenso que os evangélicos pentecostais e os não determinados (4,7\% em 1991, 7,4\% em 2000 e 8,0\% em 2010). Por fim, percebese que o número de evangélicos de missão e outras religiosidades mantém-se aproximadamente estável. Pierucci (2006) afirma que apesar de haver uma grande diversidade de religiões no Brasil, há um massivo predomínio de católicos e evangélicos. Embora o sociólogo tenha feito tal afirmação com base nos dados do Censo de 2000, observando-se o quadro anterior pode-se notar que ela faz sentido ainda hoje, quando quase $90 \%$ da população brasileira se declaram cristã.

O crescimento pentecostal, contudo, não se dá de forma equitativa pelo país. Há maior concentração de evangélicos pentecostais em áreas urbanas, principalmente nas periferias de grandes metrópoles, com destaque para Rio de Janeiro e São Paulo. Além disso, nas áreas onde há aumento de pentecostais, há um decréscimo de católicos. Estes são maioria na maior parte do país, com maior presença em áreas rurais do Nordeste. De uma maneira geral, os dados dos censos dos últimos decênios indicam que onde há crescimento pentecostal há queda de católicos. Os mapas a seguir evidenciam essas constatações.

\footnotetext{
${ }^{9}$ Segundo Jacob, Hees et. al. (2013) esse grupo engloba pessoas com diferentes perfis (não sabem exatamente a denominação do seu grupo religioso, em função do crescimento evangélico pentecostal por fragmentação dos principais grupos; frequentam a igreja mais próxima de seu local de residência ou trabalho; frequentam igrejas de outras confissões por mudança de endereço na própria cidade ou em outra cidade). Considera-se pouco provável que os evangélicos não determinados pertençam a uma das confissões evangélicas de missão, uma vez que esse grupo vem se mostrando muito estável ao longo dos últimos 30 anos, ao se manterem com percentuais entre 3\% e $4 \%$ da população brasileira. Além disso, sabe-se que a dinâmica da mudança religiosa no país vem se dando, fundamentalmente, por conta da onda pentecostal.
} 


\section{Religião Católica Apostólica Romana - 2010}

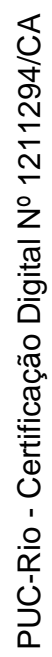

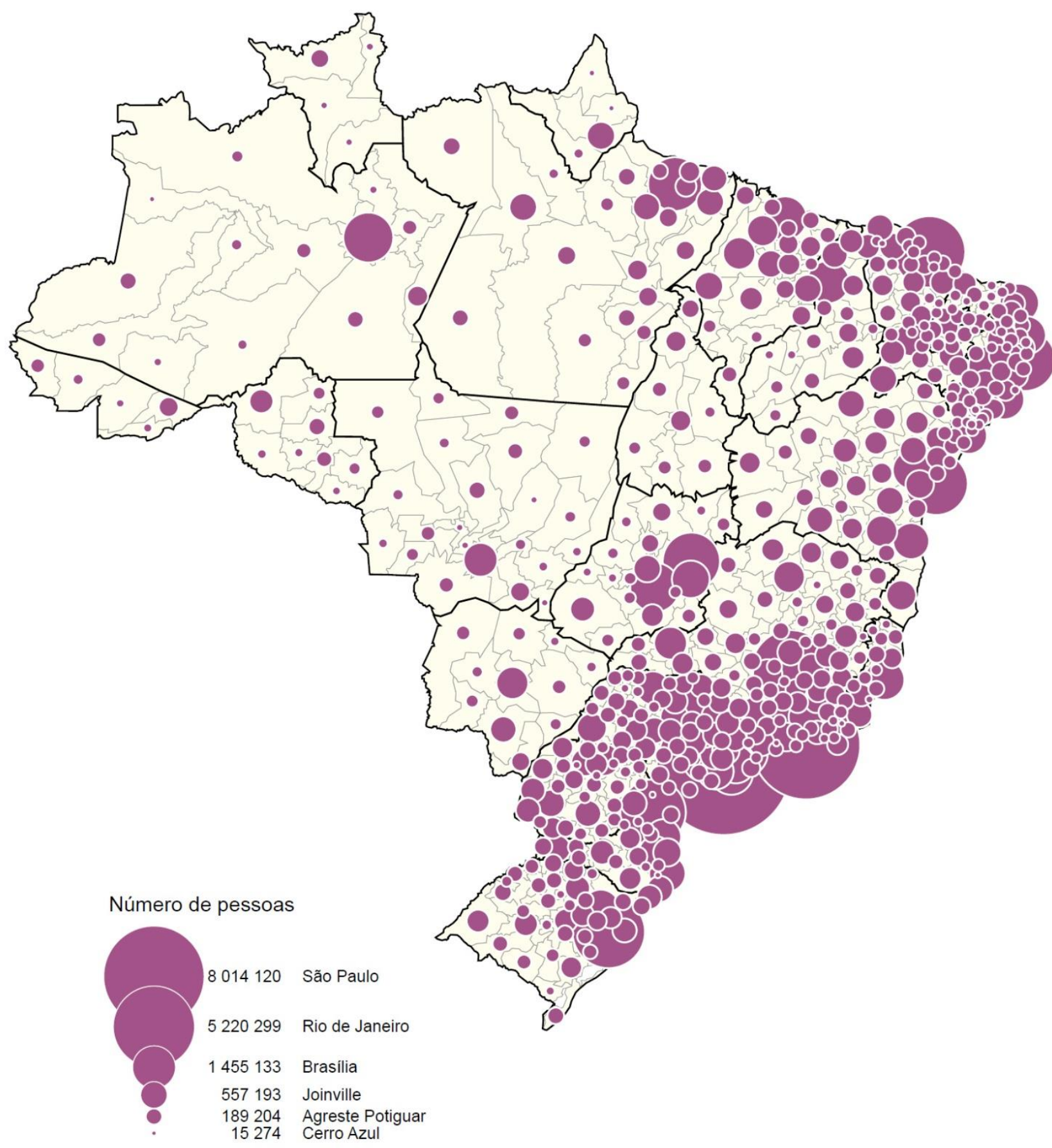

Figura 2.1: Religião Católica Apostólica Romana 2010. Fonte: Jacob, Hees et. al.(2013), IBGE, Censo Demográfico 2010. 
Religião Católica Apostólica Romana - 2010

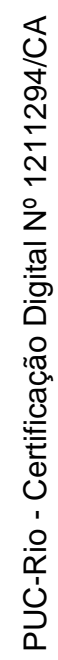

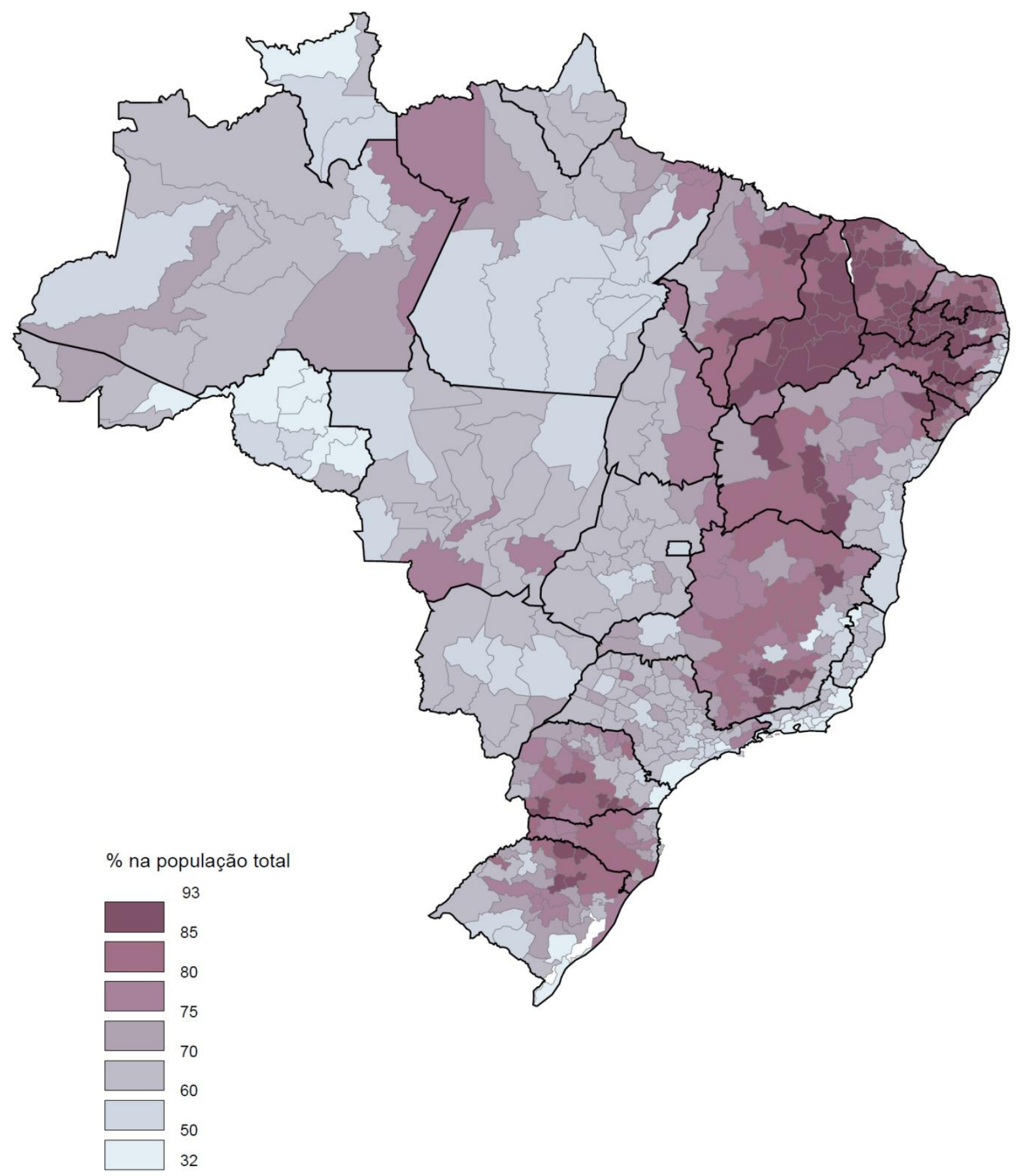

Figura 2.2: Religião Católica Apostólica Romana 2010. Fonte: Jacob, Hees et. al. (2013), IBGE, Censo Demográfico 2010. 


\section{Religião Católica Apostólica Romana \\ Variação absoluta e relativa 1991/2010 \\ (com desconto do crescimento demográfico)}

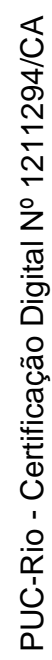

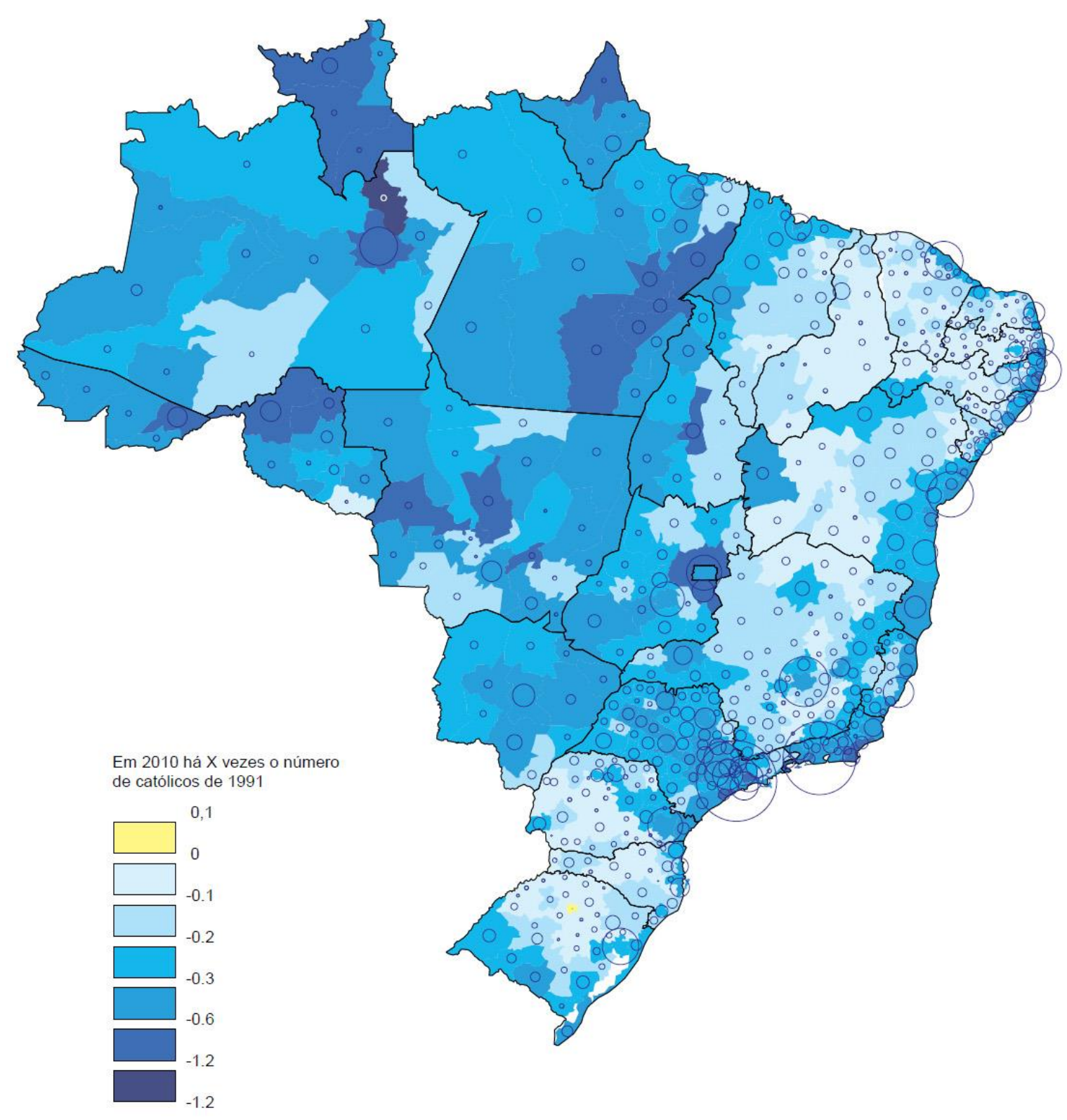

Em 2010 há Y católicos

a menos que em 1991

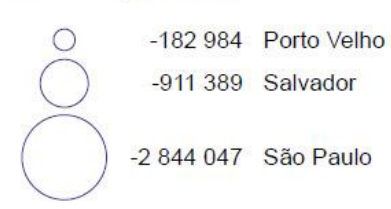

Figura 2.3: Religião Católica Apostólica Romana. Variação absoluta e relativa 1991/2010 (com desconto do crescimento demográfico) Fonte: Jacob, Hees et. al. (2013), IBGE, Censo Demográfico 2010. 


\section{Religiões Evangélicas Pentecostais - 2010}

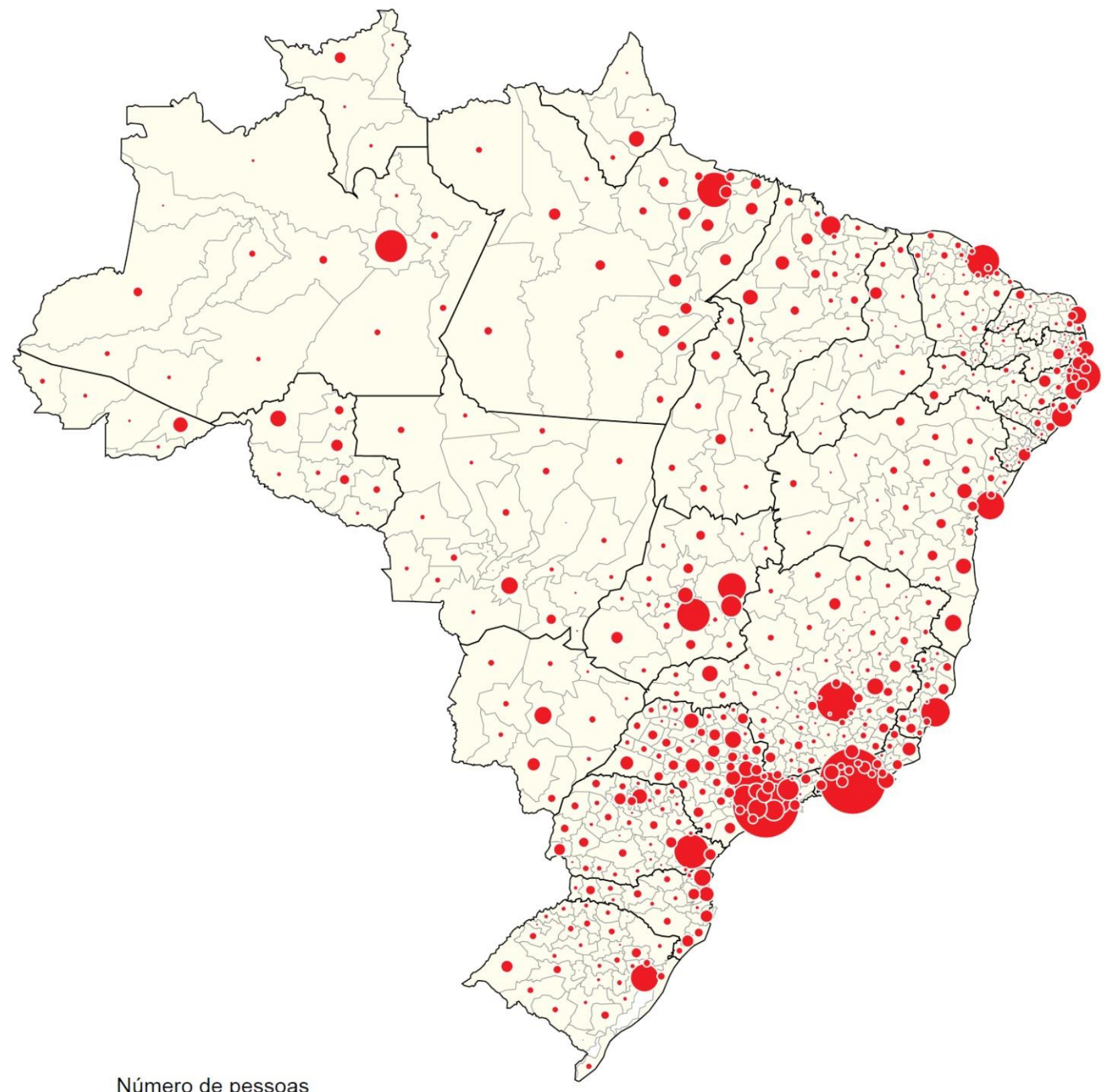

Número de pessoas

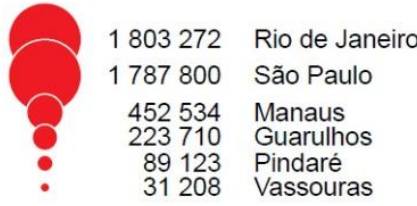

Figura 2.4: Religiões Evangélicas Pentecostais 2010. Fonte: Jacob, Hees et. al..(2013), IBGE, Censo Demográfico 2010. 
Religiões Evangélicas Pentecostais - 2010

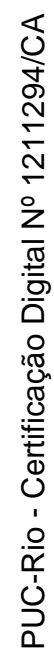

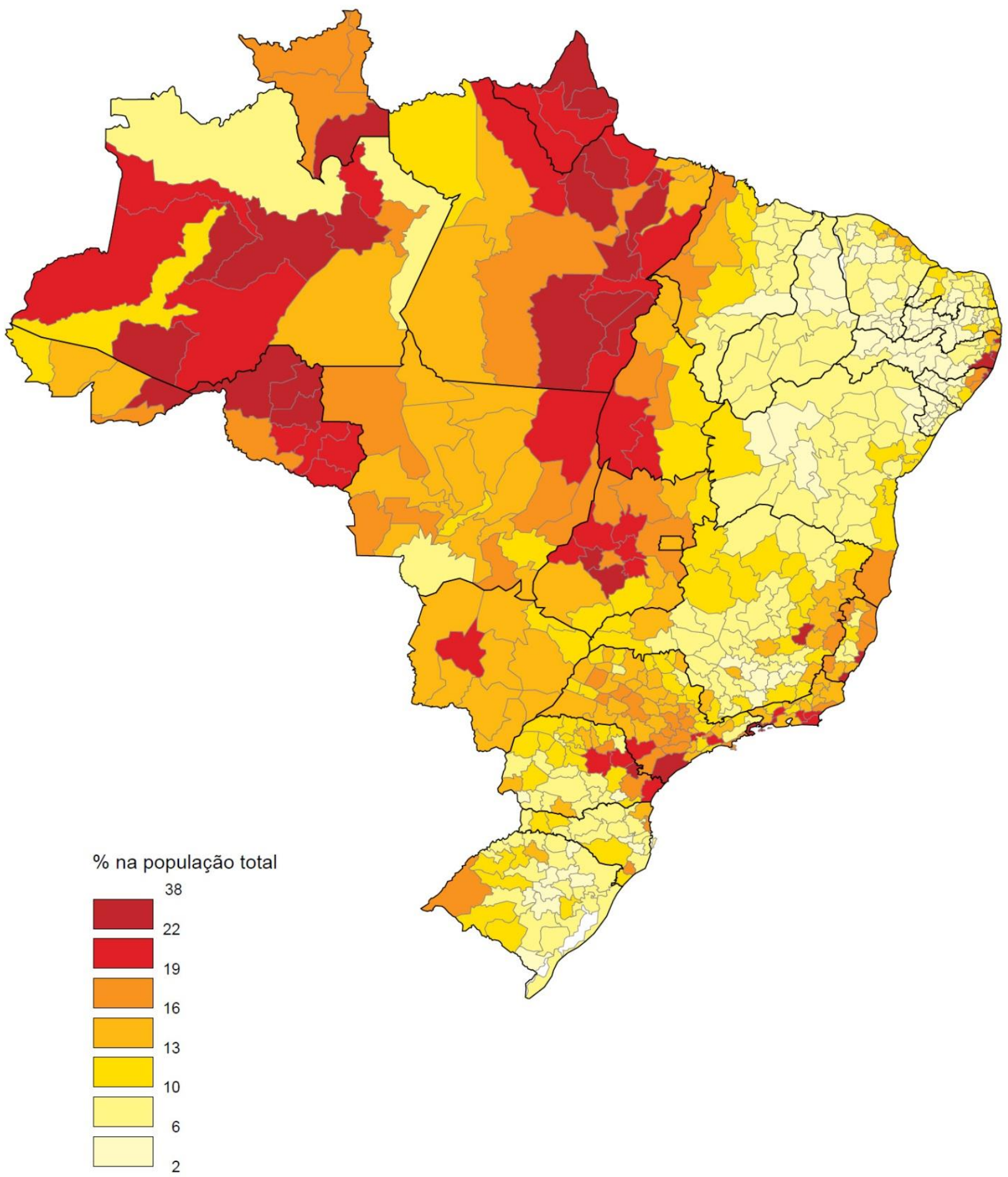

Figura 2.5: Religiões Evangélicas Pentecostais 2010. Fonte: Jacob, Hees et. al..(2013), IBGE, Censo Demográfico 2010. 


\section{Religiões Evangélicas Pentecostais \\ Variação absoluta e relativa 1991/2010 (com desconto do crescimento demográfico)}

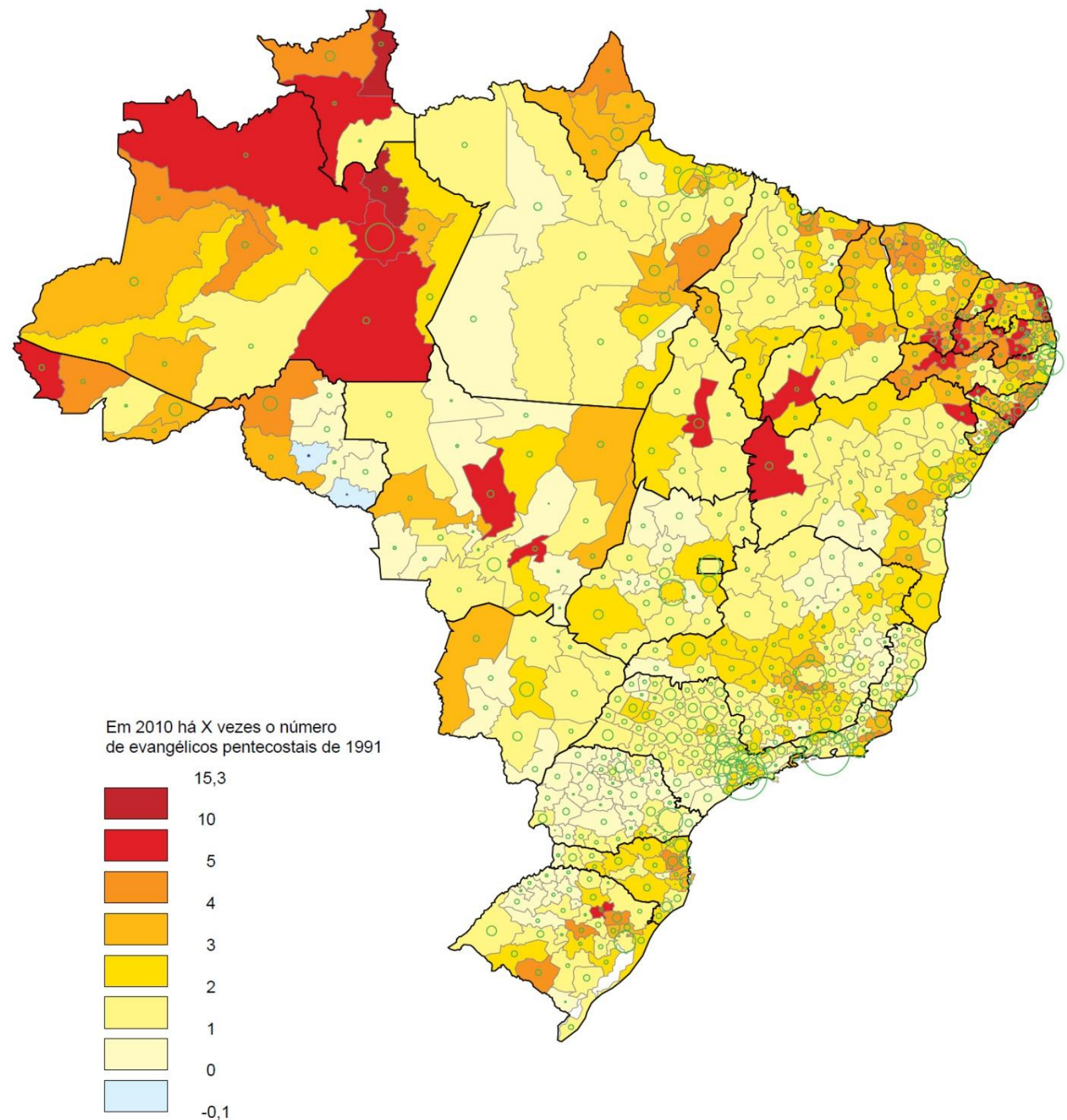

Em 2010 há Y evangélicos pentecostais a mais que em 1991

$\left\{\begin{aligned}+1035519 & \text { São Paulo } \\ +908014 & \text { Rio de Janeiro } \\ +290577 & \text { Goiânia } \\ +153329 & \text { Mogi das Cruzes } \\ +62465 & \text { Campos dos Goytacazes }\end{aligned}\right.$

Figura 2.6: Religiões Evangélicas Pentecostais. Variação absoluta e relativa 1991/2010 (com desconto do crescimento demográfico).Fonte: Jacob, Hees et. al..(2013), IBGE, Censo Demográfico 2010. 
Na Figura 2.1 percebe-se o grande número de católicos espalhados por diversas regiões no país. Entretanto, em relação ao total da população (Figura2.2) é possível observar que sua presença é maior no interior de estados como Piauí, Ceará e Paraíba e menor em São Paulo, Rio de Janeiro e Espírito Santo. O movimento de queda fica claro na Figura 2.3, na qual se vê que houve redução no número de católicos em todo país, com destaque para a região Sudeste (exceto Minas Gerais, principalmente no interior), e crescimento pouco relevante apenas em uma pequena região no interior do Rio Grande do Sul.

Situação inversa é percebida quando analisamos os quadros referentes aos evangélicos pentecostais. Na Figura 2.4, como afirmado anteriormente, pode-se perceber que a penetração dessas religiões é maior nas regiões metropolitanas de Rio de Janeiro e São Paulo e em algumas capitais. Na Figura 2.5, observa-se que, relativamente ao total da população, concentram-se nas regiões Sudeste e Norte, mais têm pouca presença no Nordeste (exceto pela região metropolitana de Recife). Por fim, e mais importante, a Figura 2.6 evidencia que houve crescimento pentecostal na última década em praticamente todo o país (com exceção de pequeníssima queda em áreas no interior de Rondônia), com destaque para o crescimento em São Paulo e Rio de Janeiro.

Além dos mapas anteriormente mostrados, é interessante observar a tabela 2.2, pois nela estão indicados os dez bairros de maior concentração de evangélicos de origem pentecostal na cidade do Rio de Janeiro, um dos contextos de nossa pesquisa. Como discutido anteriormente, percebe-se que a maior parte dessas localidades faz parte da Zona Oeste, região mais pobre e carente da metrópole carioca, ainda que conte com bairros que são como ilhas de riqueza, tal como Barra da Tijuca e Itanhangá. 


\begin{tabular}{lr}
\hline Bairros $^{\mathbf{1 0}}$ & Evangélico de Origem Pentecostal \\
\hline Santa Cruz & $24,8 \%$ \\
Complexo do Alemão & $24,1 \%$ \\
Paciência & $23,8 \%$ \\
Cosmos & $22,0 \%$ \\
Inhoaíba & $21,4 \%$ \\
Fazenda Coqueiro, Jacaré e Coréia & $21,3 \%$ \\
Costa Barros e Barros Filho & $21,2 \%$ \\
Colégio & $21,2 \%$ \\
Senador Vasconcelos & $20,2 \%$ \\
Guaratiba & $20,1 \%$ \\
Total & $12,6 \%$ \\
\hline
\end{tabular}

Tabela 2.2: Distribuição de evangélicos de origem pentecostal pelas áreas de ponderação da cidade do Rio de Janeiro. Apenas as dez áreas de maior concentração foram indicadas. Fonte: IBGE, Censo Demográfico 2010.

Embora esse fenômeno já venha acontecendo há algumas décadas, ainda não há respostas definitivas sobre qual a razão para o crescimento pentecostal nas periferias dos grandes centros urbanos, acompanhado da queda do número de católicos. Mariano (1999) e Jacob et al.(2003)indicam que a situação precária de vida das camadas mais pobres dão pistas para entender essa realidade, mas não seria suficiente. Mariano (2001) e Pierucci (2013)defendem que a capacidade dessas denominações oferecerem uma variedade de serviços espirituais e bens simbólicos, aliada à quebra do monopólio religioso da Igreja Católica com a fundação da República também são de grande importância para compreender o aumento dos pentecostais e decréscimo dos católicos.

A partir dos dados do censo de 2010, Jacob et al. (2013) apontam que o crescimento pentecostal entre os anos de 2000 e 2010 diferem do intervalo censitário anterior. Se no período intercensitário de 1991 a 2000 o crescimento foi alavancado pela expansão das igrejas pentecostais mais importantes, na década seguinte ele se deveu ao aumento dos evangélicos não determinados, uma vez que essa categoria registrou uma expansão de 4,5\% entre 2000 e 2010, o que significou um acréscimo de 8,6 milhões de novos adeptos. Isto parece indicar que o crescimento dos evangélicos no país tenha mudado de feição na última década,

\footnotetext{
${ }^{10}$ Essa variável foi elaborada para esta pesquisa com base nas categorias utilizadas pelo IBGE. No Censo de 2010, determinados bairros foram divididos em mais de uma área de ponderação (Santa Cruz 1, Santa Cruz 2, por exemplo). Nesses casos, unimos essas áreas sob uma única nomenclatura levando em consideração os seus respectivos pesos. Outras áreas de ponderação já são tratadas pelo IBGE de forma unificada (Fazenda Coqueiro, Jacaré e Coréia, por exemplo). Nesses casos, mantivemos a nomenclatura original.
} 
com uma proliferação de pequenas igrejas, ao mesmo tempo em que se assiste a uma desconcentração da afiliação de adeptos às suas principais confissões religiosas. Assim, as igrejas pentecostais mais importantes viram o seu peso relativo estagnar e sofreram, às vezes, redução do seu número de fiéis, como é o caso da Congregação Cristã do Brasil da Igreja Universal do Reino de Deus. Pode-se concluir, em relação às principais transformações religiosas em curso no país, que apesar de a Igreja Católica estar perdendo fiéis num ritmo menos acentuado, o processo de expansão dos evangélicos, em seu conjunto, se mostra em constante avanço.

Uma vez explicitado o crescimento dos evangélicos no país nos últimos 30 anos, é importante analisar algumas de suas características que serão importantes para nossa pesquisa. Primeiramente, faz-se necessário compreender quem são os evangélicos neopentecostais e de que maneiras se diferem de outras denominações evangélicas. Embora haja discussão sobre a tipologia das denominações chamadas evangélicas, seguiremos aquela formulada por Mariano (1999), tendo em vista que analisa classificações prévias (BRANDÃO, 1980; FRESTON, 1993; MENDONÇA, 1989)e fornece algumas bases para a compreensão do campo religioso brasileiro.

Segundo Mariano (1999), o termo evangélico, na América Latina, recobre o campo religioso formado pelas denominações cristãs nascidas na e descendentes da Reforma Protestante europeia do século XVI. Designa tanto as igrejas protestantes históricas (Luterana, Presbiteriana, Congregacional, Anglicana, Metodista e Batista) como as pentecostais (Congregação Cristã no Brasil, Assembleia de Deus, Evangelho Quadrangular, Brasil para Cristo, Deus é Amor, Casa da Benção, Universal do Reino de Deus, Internacional da Graça de Deus etc.). Nascido nos Estados Unidos, no começo do século XX, o pentecostalismo distingue-se do protestantismo, por pregar, baseado no capítulo 2 do livro dos Atos dos Apóstolos, a contemporaneidade dos dons do Espírito Santo, dos quais sobressaem os dons de línguas (glossolalia), cura e discernimento de espíritos. Em outras palavras, os pentecostais, diferentemente dos protestantes históricos, acreditam que Deus, por intermédio do Espírito Santo e em nome de Cristo, continua a agir hoje da mesma forma que no cristianismo primitivo, curando enfermos, expulsando demônios, distribuindo bênçãos e dons espirituais, 
realizando milagres, dialogando com seus servos, concedendo amostras concretas de seu poder e bondade.

Por sua vez, o pentecostalismo brasileiro pode ser dividido em três “ondas" (FRESTON, 1993; MARIANO, 1999): (i) pentecostalismo clássico, (ii) deuteropentecostalismo e (iii) neopentecostalismo.

O primeiro momento, pentecostalismo clássico, ocorre entre os anos 1910 e 1950, período que compreende a fundação da Congregação Cristã no Brasil (São Paulo, 1910), da Assembleia de Deus (Belém, 1911) e sua difusão pelo país. Inicialmente compostas majoritariamente por pessoas pobres e de pouca escolaridade, hoje contam também com setores de classe média, profissionais liberais e empresários. São marcadas por um forte sectarismo e ascetismo de rejeição ao mundo exterior. Ainda que algumas denominações pretendam manter seu tradicionalismo, a Assembleia de Deus - dividida em 1989 em duas denominações - mostra-se mais flexível em acompanhar certas mudanças que estão se processando no movimento pentecostal, como o envolvimento na política partidária e o ingresso no televangelismo ${ }^{11}$.

A segunda "onda", deuteropentecostalismo, surge nos anos 1950, na cidade de São Paulo. Suas principais denominações são Evangelho Quadrangular (São Paulo, 1953), Brasil para Cristo (São Paulo, 1955), Deus é Amor (São Paulo, 1962) e Casa da Benção (Belo Horizonte, 1964). Diferentemente da onda anterior, já nascem trazendo o evangelismo de massa, centrado na cura divina, difundindoa por meio do rádio, do evangelismo itinerante em tendas de lona, concentrações em praças públicas, ginásio de esportes, etc. Com mensagem sedutora e métodos inovadores e eficientes, atraíram, além de fiéis e pastores de outras confissões evangélicas, milhares de indivíduos dos estratos mais pobres da população, muitos dos quais migrantes nordestinos. Causaram escândalo e reações adversas por toda a parte. Mas, ao chamarem atenção da imprensa, que os ridicularizava e os acusava de charlatanismo e curandeirismo, conseguiram pela primeira vez dar visibilidade a esse movimento religioso no país.

É importante destacar que, segundo Mariano (1999), a diferença entre as duas primeiras ondas é mais de caráter histórico-institucional do que teológico. As igrejas da segunda onda mantêm o núcleo teológico do pentecostalismo clássico,

\footnotetext{
${ }^{11}$ Evangelização feita através de programas televisivos.
} 
contudo se estabelece quarenta anos depois e enfatiza o dom de cura do Espírito Santo, enquanto a primeira onda enfatizava o dom de línguas. Sobre o prefixo deutero, o autor explica que este significa segundo ou segunda vez, o que exprime a especificidade desse momento.

A terceira onda, o neopentecostalismo, é a que tem chamado mais atenção nos últimos anos no Brasil. Iniciada na década de 1970 e surgida no Rio de Janeiro, expandiu-se fortemente nas décadas de 1980 e 1990. Segundo Mariano (1999), a partir da Igreja de Nova Vida (Rio de Janeiro, 1960) surgiram a Igreja Universal do Reino de Deus (Rio de Janeiro, 1977), a Igreja Internacional da Graça de Deus (Rio de Janeiro, 1980) e Cristo Vive (Rio de Janeiro, 1986). Além dessas, a Comunidade Evangélica Sara Nossa Terra (Goiás, 1976), Comunidade da Graça (São Paulo, 1979), Renascer em Cristo (São Paulo, 1986), Igreja Nacional do Senhor Jesus Cristo (São Paulo, 1994) e Mundial do Poder de Deus (São Paulo, 1998), constam entre as principais igrejas surgidas na terceira onda.

Esse novo movimento do pentecostalismo representa mais do que um corte histórico-institucional, como no caso entre a primeira e a segunda ondas. Há no neopentecostalismo diferenças teológicas, comportamentais e sociais em relação às anteriores. De acordo com Mariano (1999), excetuando-se as características que são igualmente válidas para o pentecostalismo clássico e o deuteropentecostalismo (antiecumenismo, líderes fortes, uso de meios de comunicação de massa, estímulo à expressividade emocional, participação na política partidária, pregação da cura divina), o neopentecostalismo traz como marcas: (i) exacerbação da guerra espiritual contra o diabo e seu séquito de anjos decaídos; (ii) pregação enfática da Teologia da Prosperidade; (iii) liberalização dos estereotipados usos e costumes de santidade; (iv) estruturação empresarial ${ }^{12}$. Deter-nos-emos especificamente à primeira característica, a qual fornece elementos importantes para nossa hipótese de pesquisa.

A figura do diabo tem significado bastante distinto para diferentes vertentes do cristianismo. As teologias católica e protestante, além de tratar o diabo como metáfora e abstração, veem as curas milagrosas e as intervenções

\footnotetext{
12 Aqui cabe a ressalva feita por Mariano (1999) de que nem todas as igrejas surgidas nesse período podem ser consideradas neopentecostais, pois não possuem essas características apontadas. Além disso, não há homogeneidade teológica entre elas e há crescente influência dessas igrejas sobre outras denominações, que tentam se adaptar a essa nova realidade mantendo seus fiéis e conseguindo novos.
} 
sobrenaturais como excepcionalidades da história e não como algo recorrente ou parte da vida cotidiana dos indivíduos. Ao fundamentar sua interpretação da Bíblia nos métodos e na epistemologia das ciências humanas, essas teologias adquiriram caráter hermético, erudito, dessacralizando o mundo, a natureza, a história e as relações entre os seres humanos. Obtiveram sucesso em alguns setores da sociedade, sem, no entanto, alcançar amplos setores da sociedade, estando hoje em declínio. Suas interpretações da Bíblia, entretanto, causaram nos EUA do século XIX, verdadeiro horror em diversos grupos cristãos, provocando reações contrárias dos cristãos tradicionalistas e dos fundamentalistas, todos profundamente crentes no poder do diabo. No século seguinte, essas teologias não fizeram sentido para os pentecostais, pobres e de pouca escolaridade, comumente alheios à hermenêutica da erudição teológica, mas igualmente presos ao literalismo bíblico e crentes na personificação do mal:

É entre essa maioria que o pentecostalismo, de todas as vertentes, vai se instalando com seus mitos, crenças e práticas rituais notavelmente mágicos. Pastores e fiéis enxergam a ação divina e demoníaca nos acontecimentos mais insignificantes do cotidiano. Para eles, não há acaso. Tudo é prenhe de sentido, e a Bíblia contém todas as respostas de que precisam. Daí a banalização de fenômenos sobrenaturais nas igrejas pentecostais. E tudo indica que, diferentemente dos grupos e teólogos cristãos liberais, estes crentes não estão nem um pouco dispostos a abrir mão do sentido que o personagem do Diabo e do seu criador oponente, Deus, são capazes de conferir à caótica, precária e sofrida, vida humana. Passados dois milênios, a boa nova de que Cristo e seus servos possuem poder para derrotar Satanás e seus demônios, como salientou Weber a respeito do cristianismo primitivo, firma-se agora como uma das mais destacadas e eficazes promessas dos neopentecostais. (MARIANO, 1999, p.110)

Em suma, percebe-se que este é um grupo religioso em crescimento no Brasil, principalmente nas periferias dos grandes centros urbanos, que vem desestabilizando a hegemonia católica e que não possui homogeneidade interna, mas, de maneira geral, fundamenta-se na guerra ao diabo, na Teologia da Prosperidade e na flexibilização dos usos e costumes dos pentecostais tradicionais. Além disso, como Mendonça (2006, p. 96)afirma, alguns desses grupos apresentam características do fundamentalismo:

Para o fundamentalismo, ou se aceita a Bíblia no seu todo, sua inspiração plena e inerrante nos manuscritos originais, ou não se tem cristianismo. Rejeita toda crítica que ponha em dúvida a autenticidade de qualquer parcela da escritura, inclusive a teologia paulina, objeto de reticências por parte de muitos liberais. Resiste firmemente à ciência nos pontos em que colide com a leitura literal da bíblia, especialmente a teoria da evolução. 
Nesse sentido, remetemo-nos novamente aos trabalhos de Evans e Evans (2008) e Evans (2011) que defendem que o conflito entre ciência e religião é, em diversas situações, mais de ordem moral do que epistemológica. Quando a explicação científica não incorre em um conflito com a visão religiosa (por exemplo, a fotossíntese), mesmo os grupos religiosos mais conservadores não rejeitam a visão científica. Entretanto, quando há um conflito mais agudo entre ciência e religião (por exemplo, a evolução humana), opta-se por rechaçar a visão científica e permanecer com a religiosa ou, segundo nossa pesquisa de mestrado, em cotejar a visão científica à religiosa. Segundo nossa compreensão, não há, portanto, um conflito epistemológico geral, mas sim conflitos morais localizados.

Estes resultados devem também fazer-nos repensar nossas suposições quando observamos o conflito organizado entre cientistas e religiosos. Por exemplo, o conflito sobre o ensino da teoria neo-darwinista nas escolas públicas continua, e entendimento comum é que o os protestantes conservadores se opõem a tal ensino por razões epistemológicas. Pensa-se que os fundamentalistas acreditam que a verdade sobre as origens humanas pode ser encontrada na Bíblia e não em investigações científicas de fósseis. (...) Eu concordaria, mas note que a oposição a este "erro" não significa que os protestantes conservadores se opõem ao método científico em outras áreas de investigação. Esta pesquisa também sugere que a solução para os conflitos sobre a evolução, para pessoas comuns, e não ativistas, não é ensinar as pessoas religiosas o método científico, ou mostrar como as instituições científicas produzem o conhecimento verdadeiro. Os protestantes conservadores já aceitam isso. Em vez disso, trata-se de convencer os protestantes conservadores de que os cientistas não estão sistematicamente enviesando os resultados do seu conhecimento e que os fundamentalistas devem tratar de biologia como química, uma disciplina científica que parecem aceitar. Esta pode ser uma tarefa educativa mais complexa, mas provavelmente aproxima-se mais do problema real. (EVANS, 2011, p.724) ${ }^{13}$

Não queremos afirmar que o fiel evangélico neopentecostal vê a ciência como uma atividade demoníaca ou que perceberia Darwin como um representante do anticristo. Contudo, segundo as pesquisas aqui mencionadas, quando se depara

\footnotetext{
${ }^{13}$ No original: These findings should also make us rethink our assumptions when we observe organized conflict between scientists and religious people. For example, conflict continues over the teaching of neo-Darwinist theory in public schools, and the common understanding is that conservative Protestants are opposed to such teaching on epistemological grounds. Fundamentalists are thought to believe that the truth about human origins can be found in the Bible, not in scientific investigations of fossils. Following the results of this article, I would agree but note that opposition to this one "error" does not mean that conservative Protestants are opposed to scientific method in other areas of inquiry. This study also suggests that the solution to conflicts over evolution - for ordinary people, not activists-is not in teaching religious people the scientific method, or in showing how scientific institutions produce true knowledge. Conservative Protestants already accept that. Rather, it lies in convincing conservative Protestants that scientists are not systematically biasing the findings of their knowledge and that fundamentalists should treat biology like chemistry, a scientific discipline they seem to accept. This may be a more intractable educational task, but it probably edges closer to the actual problem. Tradução livre.
} 
com uma situação em que há um claro conflito de explicações entre ciência e religião, ele rejeita ou relativiza a teoria científica e ancora-se, com mais ou menos força, à religiosa. Assim, perceberia que a teoria da evolução não é um conhecimento religioso e, portanto, não tão moralmente "seguro" quanto o que a leitura literal da Bíblia lhe diz. Essa hipótese, pouco explorada pelos trabalhos encontrados na revisão de bibliografia desta pesquisa, pode fornecer novas pistas para o entendimento do nosso tema de investigação.

\section{3.}

\section{Multiculturalismo e interculturalidade: perspectivas de análise}

O multiculturalismo, enquanto construção teórica, possui diferentes concepções e interpretações. Da mesma forma, diversas perspectivas de educação multi/intercultural são defendidas por autores com distintas abordagens, tais como McLaren (1997), Banks (1999), Forquin (1993), Walsh (2009) e Candau (2002).

De forma mais usual, o termo multiculturalismo é utilizado para descrever um contexto social plural e diverso, no qual identificamos várias culturas. No entanto, para além da descrição sobre a pluralidade, encontramos perspectivas de intervenção social. Assim, o chamado "multiculturalismo crítico", defendido por McLaren (1997), pauta-se numa agenda de política de transformação, sem a qual se corre o risco do mero assimilacionismo, ou seja, de se reduzir o multiculturalismo a uma forma de acomodação à ordem social vigente. Além disso, o multiculturalismo crítico vê as representações de raça, gênero e classe como produto de lutas sociais sobre significações e se recusa a ver a cultura como não-conflitiva.

Por sua vez, Banks (1999) defende que a educação multicultural deva ser um movimento reformador provocando profundas mudanças, principalmente, no sistema educacional. Sua principal finalidade seria favorecer aos estudantes o desenvolvimento de habilidades, atitudes e conhecimentos necessários para atuar tanto no contexto da sua própria cultura quanto da cultura dominante.

Forquin (1993), por sua vez, defende perspectiva um pouco diferente das anteriores. Para ele, multiculturalismo em educação deve lidar com a tensão entre o universal e o particular, ressaltando que o universal não é necessariamente etnocêntrico e dominador e seria compatível com o reconhecimento e o respeito às 
diferenças. Assim, caberia à escola transmitir saberes "públicos" estritamente formulados e controlados, aos quais todos possam ter acesso potencial e que apresentem valor independentemente das circunstâncias e dos interesses particulares.

Candau (2002)aponta que o multiculturalismo pode ser entendido de duas formas: (i) descritiva e (ii) propositiva. A primeira aborda o multiculturalismo como uma realidade social na qual convivem diferentes grupos sociais, porém não trata das relações entre eles. As posturas propositivas partem da tomada de consciência da presença de diferentes grupos em uma mesma sociedade que, em geral, é motivada por fatos concretos que explicitam interesses diversos, discriminações e preconceitos. O "normal" ou "natural" acaba se revelando permeado por relações de poder e historicamente construído. Nesse sentido, a autora destaca três posturas propositivas: (i) multiculturalismo assimilacionista; (ii) multiculturalismo diferencialista; (iii) multiculturalismo interacionista. Este último seria, na perspectiva assumida pela pesquisadora, como interculturalidade crítica.

O multiculturalismo assimilacionista reconhece a existência de diferentes grupos sociais e as desigualdades entre eles. A fim de superá-las, propõe políticas que integrem esses grupos marginalizados à cultura hegemônica sem, no entanto, modificar a matriz da sociedade. Afirma-se, assim, uma cultura comum em detrimento de uma postura que efetivamente valorize as diferenças.

O multiculturalismo diferencialista, em oposição ao anterior, enfatiza o reconhecimento das diferenças, afirmando a necessidade de garantir espaços próprios e específicos em que estas possam se expressar com liberdade coletivamente. Candau (2008) pondera que algumas das posições nesta linha terminam por ter uma visão estática e essencialista da formação das identidades culturais. A autora ressalta que, na prática, essa perspectiva terminou por favorecer a criação de verdadeiros apartheids socioculturais.

A terceira orientação, a interculturalidade crítica, com a qual Candau (2002) se alinha, parte do pressuposto que o caráter multicultural de uma sociedade não a leva espontânea e necessariamente ao desenvolvimento de uma dinâmica social que mobilize processos de diálogo entre as diferentes culturas. A interculturalidade supõe a deliberada inter-relação entre diferentes grupos socioculturais. 
A interculturalidade orienta processos que têm por base o reconhecimento do direito à diferença e a luta contra todas as formas de discriminação e desigualdade social. Tenta promover relações dialógicas e igualitárias entre pessoas e grupos que pertencem a universos culturais diferentes, trabalhando os conflitos inerentes a esta realidade. (CADAU, 2002, p. 99)

Walsh (2009) afirma que a interculturalidade deve ser entendida como proposta de sociedade, projeto político, social, epistêmico e ético para a transformação estrutural e sócio-histórica da sociedade. Esta proposta estaria baseada na reconstrução de novas condições de saber, ser e poder (WALSH, 2009). Além disso, a interculturalidade deve estar entrelaçada e caminhar junto com a noção de decolonização, isto é, uma ampla mudança do paradigma eurocêntrico para um que se paute nos conhecimentos produzidos em contextos colonizados. Walsh (2009) e Mignolo (2011) preferem utilizar o termo "decolonidade" para diferenciá-lo de "des-colonidade", a fim de mostrar que se trata de um processo que envolve as dimensões do ser e o conhecer e não apenas a dimensão política.

Para esta pesquisa, buscamos também elementos ético-filosóficos para fundamentar a interculturalidade no campo educacional, principalmente no que se refere ao conhecimento escolar. Andrade(2009), por exemplo, entende o conceito de tolerância não como uma postura de simples aceitação resignada da diferença ou de uma indiferença bondosa, mas como respeito ativo. Assim, a tolerância como um dos fundamentos éticos e epistemológicos da interculturalidade reconhece os direitos do outro, implica na alteridade e se opõe à passividade e ao dogmatismo. Nesse sentido, a tolerância ética e epistemológica estaria relacionada ao campo da justiça e seria capaz de unificar três diferentes demandas: (i) a liberdade de pensamento, expressão e associação; (ii) a igualdade de acesso a direitos, oportunidades e bens sociais e (iii) o direito à diferença e ao pluralismo de identidades. Uma educação intercultural baseada no conceito de tolerância buscaria reconhecer o valor absoluto de cada ser humano e a obrigação moral de construir, através do diálogo, normas e conhecimentos compartilhados para garantir a pluralidade. Esta perspectiva de entendimento do conceito de tolerância aponta para uma nova perspectiva sobre a universalidade, garantindo a particularidade de cada ser humano como um ser absolutamente valioso.

Para entender esta nova perspectiva de universalidade, recorremos à obra da filósofa Adela Cortina, herdeira da ética do discurso, que propõe uma 
articulação entre o que é justo e o que é bom, isto é, uma maneira de estabelecer o diálogo entre diferentes culturas e encontrar consensos possíveis para uma sociedade plural, o que a autora identifica nos conceitos de "ética de mínimos" e “ética de máximos”(CORTINA, 1996, 2005).

A ética de mínimos, como ressalta Cortina (1996), não se refere a uma "liquidação moral" ou atitudes morais minimalistas, preocupadas em cumprir o mínimo possível. Na verdade, são valores, conhecimentos e significados que todos compartilham e que uma sociedade pluralista não está disposta a renunciar. Os mínimos são exigências, no sentido de que os cidadãos vivam sobre determinadas orientações de justiça. A ética de máximos ou os máximos de felicidade, por outro lado, seriam os diferentes projetos para que se alcance aquilo que é bom para cada indivíduo ou grupo. Logo, apenas se pode convidar alguém a aceitá-lo, já que se trata fundamentalmente de uma realização pessoal e intransferível.

As éticas da justiça ou éticas de mínimos ocupam-se unicamente da dimensão universalizável do fenômeno moral, isto é, daqueles deveres de justiça exigíveis de qualquer ser racional, e que, efetivamente, só são constituídos de exigências mínimas. Ao contrário, as éticas da felicidade pretendem oferecer ideais de uma vida digna e boa, ideais que se apresentem hierarquizadamente e englobam o conjunto de bens que os homens usufruem como fonte da maior felicidade possível. São, pois, éticas de máximos, que aconselham a seguir o modelo e convidam-nos a tomá-lo como norma de conduta, mas não podem exigir ser seguidos, visto que a felicidade é tema de aconselhamento, e não de exigência. (CORTINA, 1996, p. 62)

Portanto, a justiça - e aqui incluímos a tolerância - tem a ver com o que é exigível de qualquer ser racional. O justo satisfaz a interesses universalizáveis, o que supõe o diálogo - em condições de simetria - entre todos os afetados por normas, conhecimentos e significados que devem entrar em vigor. O bom, isto é, aquilo que causa felicidade, não pode ser exigido de outros seres racionais, pois é, em geral, uma expressão de uma adesão subjetiva, identitária ou grupal(CORTINA, 1996).

Cortina (1996) assume, dessa forma, uma postura contrária tanto a um relativismo exacerbado quanto a um absolutismo autoritário. Apostando frontalmente no diálogo, defende ser possível encontrar valores, conhecimentos e sentidos compartilhados por todos. É preciso perceber que não se defende uma postura assimilacionista na qual as culturas minoritárias simplesmente aderem à dominante, mas sim de uma postura intercultural, que de acordo com Cortina 
(2005), trata-se da tomada de consciência de que nenhuma cultura tem soluções para todos os problemas vitais e que toda cultura pode aprender com as demais. Além disso, a interculturalidade não consiste na defesa da diferença pela diferença, mas visa assegurar uma convivência autêntica, respeitando a identidade dos diferentes grupos das sociedades plurais, compreendendo-a como algo que os sujeitos, ao menos em parte, escolhem e não uma realidade à qual estão fatalmente destinados.

Para esta pesquisa, a perspectiva de Cortina (CORTINA, 1996, 2005) é fundamental, já que as religiões podem ser entendidas como "máximos de felicidade", uma vez que sua escolha, em geral, é pessoal e subjetiva. Já o diálogo e a tolerância (ética e epistemológica) são vistos como mínimos exigíveis para a convivência. Além disso, Cortina (1996, p. 57-58) nos faz um alerta:

Os educadores também têm de saber quais são os seus "mínimos decentes" de moralidade na hora de transmitir os valores, sobretudo no que diz respeito à educação pública numa sociedade pluralista. Pois é certo que, por serem educadores, não têm legitimidade para transmitir, sem mais, apenas os valores que lhes pareçam oportunos. [...] Não seria urgente descobrir quais são os valores que podemos partilhar e que vale a pena ensinar? É ou não é urgente descobrir um "mínimo decente de valores" já partilhados?

Assim, nossa perspectiva aqui é que a educação intercultural pode se configurar como um espaço para a construção de uma agenda mínima entre as diferentes culturas de uma sociedade plural. É preciso que esteja clara a diferença entre propostas de felicidade, que podem ser aceitas ou não, e exigências de justiça, que todos temos obrigação de aceitar. Nesse sentido, os argumentos de Cortina (1996, 2005) e Andrade (2009) podem contribuir com a reflexão sobre o papel do professor de biologia em relação a possibilidade de conflitos com o criacionismo no cotidiano de suas salas de aula. Entendemos a religião do docente como um máximo de felicidade e, portanto, um projeto subjetivo que lhe satisfaz. Não seria aceitável, no entanto, que o impusesse aos alunos, pois isto desrespeitaria a tolerância ética e epistemológica como um mínimo exigível. Tampouco, o professor poderia desrespeitar os máximos de felicidades dos estudantes em nome do ensino de biologia, ou seja, o ensino de biologia - como um mínimo epistemológico ou o conhecimento compartilhado - não poderia ser imposto, sem mais, sem respeito às confissões religiosas dos educandos.

Vale registrar que, baseada em sua importância para o desenvolvimento do pensamento biológico (DOBZHANSKY, 1973; MAYR, 1982, 2009) e para o 
ensino de biologia (BRASIL, 1998, 2006), parto do pressuposto que a evolução é um dos mínimos epistemológicos, ou seja, um conhecimento mínimo, compartilhado por uma comunidade científica, exigível à biologia enquanto disciplina acadêmica e disciplina escolar. Logo, o professor de biologia, independentemente de sua religião, supostamente assumiria um compromisso de ensinar a evolução biológica e não o criacionismo ou qualquer outra hipótese relacionada às crenças religiosas.

Pelos argumentos expostos, consideramos que a teoria da evolução se estabelece, atualmente, como um mínimo epistemológico compartilhado para o ensino de biologia. Esses mínimos são encontrados a partir de um jogo político marcado por tensões e acordos entre as diferentes abordagens deste campo disciplinar. As justificativas que tornariam a teoria da evolução parte de um mínimo definidor do currículo escolar de biologia são resultados das convenções - ainda que provisórias - notabilizadas tanto pela comunidade científica quanto escolar. Assim, poderíamos indicar que há razões éticas, epistemológicas e políticas para que o ensino de biologia não adote perspectivas criacionistas, ainda que as crenças evangélicas neopentecostais pressionem esse mínimo, no sentido de questionar sua validade e centralidade para o conhecimento de como os seres vivos surgiram e se desenvolveram ao longo da história da Terra. Neste sentido, para além de um conflito epistemológico, a tensão entre a perspectiva criacionista predominante entre neopentecostais mobilizaria também um conflito moral, que precisará ser negociado com mínimos éticos socialmente acordados.

\section{4}

\section{O modelo de espaço de busca baseado no Discurso Habermasiano}

Baseados nos dados da pesquisa e na literatura da área, propomos um modelo para o diálogo em sala de aula baseado nos conceitos de "espaço de busca" (search space) de France (2011) e "discurso" (Diskurs) de Habermas $(1984,1989)$ entre professores e estudantes sobre o tópico de evolução. De acordo com France (2011), o modelo de espaço de busca está baseado na premissa de que o diálogo entre dois grupos só pode ocorrer sob circunstâncias específicas, isto é, quando há um "espaço" que permite aos participantes questionar uns aos outros e desenvolver certo entendimento comum. A autora defende que o espaço de busca 
consiste na interseção, em uma área virtual, dos componentes dos pontos de vista de duas comunidades. É nesse espaço de busca que as pessoas podem discutir e chegar a um acordo apesar das diferenças de suas crenças, atitudes e comportamentos. Onde há similaridade nos elementos das visões das duas comunidades, a comunicação é possível. Entretanto, se não há tal semelhança, surge um espaço de busca no qual certo nível de entendimento deverá ser desenvolvido. Quando houver similaridade de entendimento suficiente haverá possibilidade para o diálogo.

Tal ideia se aproxima dos trabalhos de Habermas (1984) sobre ação comunicativa e os atos de fala nas sociedades modernas. Para o filósofo alemão, a sociedade é uma estrutura intersubjetiva, que compreende esferas que se sobrepõem, na qual os agentes individuais interagem. Além disso, baseando-se em uma concepção pragmática da linguagem, ele argumenta que a função da fala é levar os interlocutores a um entendimento compartilhado e estabelecer um consenso intersubjetivo, o qual fornece as bases para suas ações posteriores: "alcançar o entendimento habita a fala humana como seu telos" (HABERMAS, 1984, p.287) $)^{14}$.

Para Habermas (1989, p.79), são comunicativas as interações nas quais “as pessoas envolvidas se põem de acordo para coordenar seus planos de ação, o acordo alcançado em cada caso medindo-se pelo reconhecimento intersubjetivo das pretensões de validez". O filósofo identifica três pretensões de validez: (i) verdade, (ii) correção e (iii) sinceridade. A primeira consiste na ideia de que o que se propõe é verdadeiro, a segunda na de que é compatível com as normas apropriadas e a terceira na de que o falante é sincero sobre o significado ou a intenção do que é proposto. As duas primeiras pretensões serão avaliadas pela exposição de razões. Já a última, se baseará no comportamento e prática cotidiana do falante.

De acordo com Finlayson (2005), quando as pretensões de validade são tacitamente aceitas e satisfazem o ouvinte, a ação comunicativa foi bem sucedida. No entanto, quando não há um acordo sobre o que está sendo proposto, a verdade de uma asserção será avaliada no que Habermas chama de discurso (HABERMAS, 1984). Seu objetivo é encontrar um consenso racionalmente

\footnotetext{
${ }^{14}$ Tradução livre da versão em inglês "Reaching understanding inhabits human speech as its telos" (HABERMAS, 1984, p.287).
} 
motivado, mesmo que isto não seja sempre acessível. Na concepção habermasiana, discurso não é sinônimo de linguagem ou fala:

só me referirei a 'discurso' quando o significado de uma pretensão de validez forçar conceitualmente os participantes a suporem que um acordo racionalmente motivado pode, em princípio, ser alcançado, onde a expressão 'em princípio' expressa a condição idealizada: apenas se a discussão possa ser conduzida suficientemente aberta e com duração suficiente. (HABERMAS, 1984, p.42) ) $^{15}$

Habermas (1989, p.112) destaca que o discurso pressupõe normas para que se desenvolva de forma que as razões utilizadas para defender as afirmações feitas pelos participantes possam ser questionadas:

1 - É lícito a todo sujeito capaz de falar e agir participar de Discursos.

2 - a. É lícito a qualquer um problematizar qualquer asserção.

b. É lícito a qualquer um introduzir qualquer asserção no Discurso.

c. É lícito a qualquer um manifestar suas atitudes desejos e necessidades.

3 - Não é lícito impedir falante algum, por uma coerção exercida dentro ou fora do Discurso, de valer-se de seus direitos estabelecidos em 1 e 2.

Tendo em vista os conceitos de Habermas, o modelo que propomos baseiase na ideia de que o professor, ao ensinar evolução, deve atender às pretensões de validez em suas afirmações, bem como buscar que as discussões desenvolvidas em sala atendam às regras do discurso. Nesse sentido, espera-se que o professor de biologia ensine evolução com o objetivo de explicar ao aluno porque a teoria evolutiva é aceita pela comunidade acadêmica como cientificamente válida. Assim, afirmações como "a teoria evolutiva é apenas uma teoria e tem tanto poder explicativo quanto qualquer outra ideia" ou "os cientistas questionam a teoria evolutiva em favor do design inteligente", críticas comuns feitas por determinados grupos criacionistas (SCOTT, 2009), não atenderiam à pretensão de validez de verdade.

Adicionalmente, seguindo as regras do discurso, todo aluno teria direito de manifestar sua opinião em sala de aula, inclusive crenças religiosas que, porventura, venham a entrar em conflito com a teoria evolutiva. Contudo, aqueles questionamentos que possam ser vistos como hipóteses científicas, podem vir a ser analisados de um ponto de vista científico ao longo do discurso. Suponhamos, por exemplo, que um aluno argumente que não pode aceitar as teorias científicas

\footnotetext{
${ }^{15}$ Tradução livre da versão em ingles: "I shalI speak of "discourse" only when the meaning of the problematic validity claim conceptually forces participants to suppose that a rationally motivated agreement could inprinciple be achieved, hereby the phrase ' 'in principle" expresses the idealizing proviso: if only the argumentation could be conducted openly enough and continued long enough.(HABERMAS, 1984, p. 42).
} 
sobre a origem e evolução da vida porque, de acordo com a Bíblia, a Terra tem em torno de seis mil anos de idade. Esta afirmação pode ser questionada de um ponto vista científico, dado que há muitas evidências científicas de que nosso planeta seria muito mais antigo. No entanto, uma vez que afirmações metafísicas fogem do escopo da ciência, esta não pode ser usada para questioná-las (COBERN, 2000; SMITH; SIEGEL, 2004). Assim, a existência da alma ou de Deus não devem ser alvo da análise de um ponto de vista científico, na aula de biologia.

Consequentemente, mais do que ter por objetivo converter as visões de um grupo em outro, o espaço de busca baseado no discurso deve consistir em uma oportunidade para cada grupo explorar os outros pontos de vista. Deve haver a possibilidade de se concordar em discordar: por mais que dois grupos não concordem, ao menos são capazes de entender e discutir os pontos de vista um do outro, alcançando acordos sobre o significado de determinados conceitos. Um modelo de espaço de busca para a nossa pesquisa é apresentado a seguir (Figura 2.7):

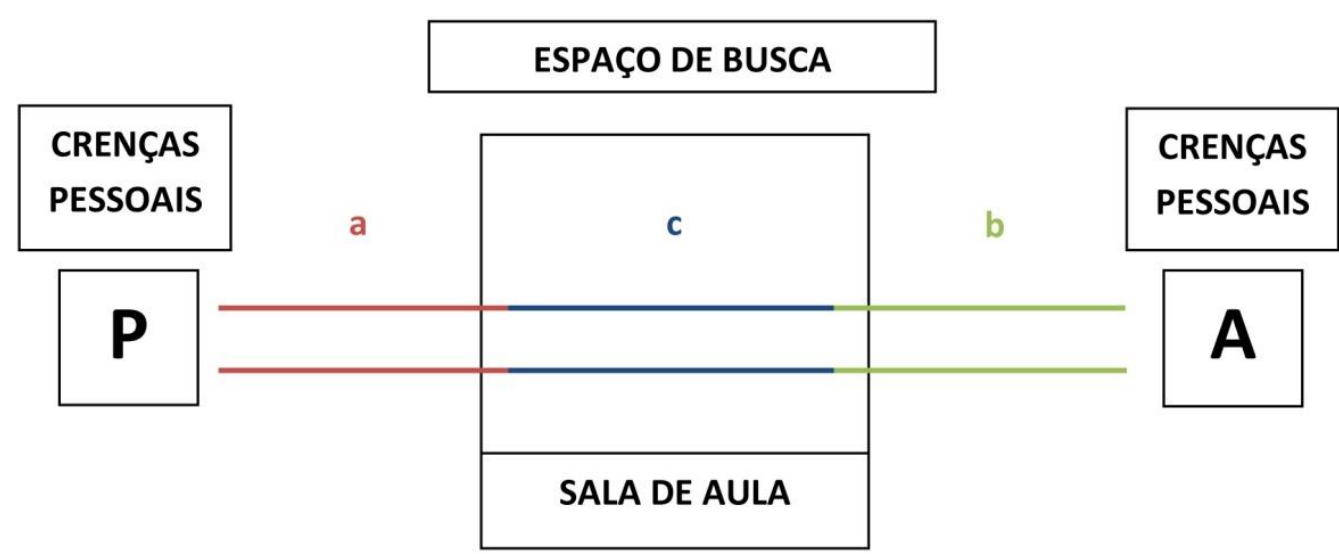

Figura 2.7. Modelo do espaço de busca.

A letra "P" representa o(a)professor(a) e "A", os(as)alunos(as). Ambos possuem "Crenças Pessoais" sobre conceitos religiosos e científicos e que baseiam as ideias que expõem em sala de aula durante um debate sobre evolução e criacionismo. As letras "a" e "b" representam o que eles disseram serem suas crenças particulares durante as entrevistas e que, portanto, foram a fonte mais direta para os pesquisadores acessarem suas crenças pessoais. A letra "c", por sua vez, representa o que eles discutiram durante as aulas observadas, suas aproximações e distanciamentos na construção de entendimentos e acordos comuns. 
O espaço de busca "ideal", baseado nos dados de nossa pesquisa, envolveria: (i) a coerência entre as crenças pessoais e o que é ensinado em sala de aula; (ii) abertura a outros pontos de vista; (iii) disponibilidade para discutir respeitosamente posições que não sejam as suas próprias. O ponto "i" se justifica, como veremos mais adiante, pelo fato de que a inconsistência entre o que o docente acredita e o que ele afirma em sala de aula, poder limitar a confiança dos estudantes. $\mathrm{O}$ segundo e o terceiro pontos estão intrinsecamente ligados e envolvem o reconhecimento de que outras visões de mundo podem ser válidas e, portanto, não devem ser desprezadas.

Tendo em vista a importância das crenças religiosas para a construção de visões de mundo e que não deveriam ser vistas como erros conceituais ou concepções alternativas, Reiss (2008) defende que o objetivo do ensino de ciências deve ser o entendimento da ciência e não a mudança de crença. Tal pensamento também é defendido por outros autores na área (COBERN, 2000; ELHANI; MORTIMER, 2007; SMITH; SIEGEL, 2004) e, nele apoiados, propomos um modelo que visa a estimular o diálogo em sala de aula, e não tentar "converter" crenças religiosas em pensamento científico.

\section{5 \\ Conclusão}

Pelos argumentos expostos, consideramos que a teoria da evolução se estabelece, atualmente, como um mínimo epistemológico compartilhado para o ensino de biologia. Esses mínimos são encontrados a partir de um jogo político marcado por tensões e acordos entre as diferentes abordagens deste campo disciplinar. As justificativas que tornariam a teoria da evolução parte de um mínimo definidor do currículo escolar de biologia são resultados das convenções - ainda que provisórias - notabilizadas tanto pela comunidade científica quanto escolar. Assim, poderíamos indicar que há razões éticas, políticas, epistemológicas e pedagógicas para que o ensino de biologia não adote perspectivas criacionistas, ainda que as crenças evangélicas neopentecostais pressionem esse mínimo, no sentido de questionar sua validade e centralidade para o conhecimento de como os seres vivos surgiram e se desenvolveram ao longo da história da Terra. Neste sentido, para além de um conflito 
epistemológico, a tensão entre a perspectiva criacionista predominante entre neopentecostais mobilizaria também um conflito moral, que precisará ser negociado com mínimos éticos socialmente acordados.

Dada a importância das crenças religiosas para a construção de diferentes visões de mundo, bem como o direito à liberdade de crença, o objetivo do ensino de evolução deve ser seu entendimento e não a mudança de crença. Dessa maneira, a perspectiva intercultural e a tolerância podem contribuir para o desenvolvimento de abordagens e orientações didáticas voltadas para a compreensão da importância da teoria evolutiva neodarwinista para o estudo do mundo natural, respeitando crenças religiosas criacionistas. Além disso, o espaço de busca, baseado no diálogo habermasiano, configura-se como uma ferramenta de análise das dinâmicas desenvolvidas em sala, estimulando o diálogo e a análise das diferenças entre o pensamento científico e o religioso. 


\section{3.}

\section{Campo e sujeitos de pesquisa}

A presente pesquisa foi conduzida em duas escolas estaduais de ensino médio do Rio de Janeiro. Dado que a questão mais ampla da pesquisa era investigar o desenvolvimento do ensino de evolução em salas de aula com grande presença de estudantes evangélicos pentecostais e neopentecostais, optamos por pesquisar uma escola em uma área de baixa presença de fiéis pertencentes a esse grupo religioso e outra em uma área com altos índices dessas denominações. Como argumentamos anteriormente, tal escolha nos permite comparar essas duas realidades e identificar se a maior presença desse grupo implica em diferenças na dinâmica das aulas de evolução. Além disso, optamos por pesquisar apenas turmas de $1^{\circ}$ ano do ensino médio regular, tendo em vista que esta é a etapa da escola básica em que está previsto o ensino de evolução e origem da vida, de acordo com o currículo mínimo estadual (SEEDUC, 2012a).

\section{1}

\section{O ensino de biologia no primeiro ano do ensino médio da rede estadual}

A carga horária da disciplina de biologia na rede estadual de ensino é de dois tempos semanais no ensino médio, o que foi considerada por todos os professores observados como insuficiente. O currículo a ser seguido é prescrito pela Secretaria Estadual de Educação (SEEDUC) e é chamado de "Currículo Mínimo” (SEEDUC, 2012a), cuja versão vigente foi elaborada em 2012 e está disponível no Anexo 1 (apenas a seção de biologia destinada ao primeiro ano do ensino médio). Ele estabelece os conteúdos a serem ensinados e seu ordenamento, os quais estariam articulados com o Saerjinho (avaliação diagnóstica comum a toda rede estadual aplicada bimestralmente e cujo nome deriva do SAERJ, Sistema de Avaliação da Educação do Estado do Rio de Janeiro). Este sistema de avaliações era, de maneira geral, rejeitado pelos professores entrevistados e pelo 
Sindicato Estadual dos Profissionais de Educação do Rio de Janeiro (SEPE), que o viam como uma forma interferir na autonomia docente, atrelando um bônus salarial caso as metas de desempenho dos estudantes fossem atingidas, o que implicaria em um treinamento dos educandos e não um processo educativo adequado (SEPE, 2012a, 2012b). Essas avaliações também não gozavam de prestígio entre os alunos das escolas pesquisadas. Nas observações que fizemos de aplicações desses exames, em menos de uma hora de prova todos os discentes já a haviam entregue ao professor, o que segunda nossa avaliação poderia indicar uma baixa adesão ao sistema. Isso significa que, em menos de sessenta minutos, já haviam lido e respondido a todas as 45 questões ${ }^{16}$ e preenchido o cartão resposta. Com frequência, o primeiro aluno terminava o teste com pouco mais de quinze minutos.

A aplicação do Saerjinho pela escola era obrigatória, mas, de acordo com o SEPE (SEPE, 2012a), o professor que não o desejasse fazê-lo não poderia ser punido, devido a um acordo prévio com a SEEDUC. As direções pedagógicas de ambas as escolas se esforçavam tanto para que todos os docentes estivessem disponíveis para aplicar as avaliações às turmas, quanto para que os alunos estivessem presentes. Assim, foram observadas estratégias como o Saerjinho contar 2,0 pontos (em 10,0) na média dos estudantes, desde que eles comparecessem ao teste, independentemente de suas respostas. $\mathrm{Ou}$, a fim de contar com a cooperação dos docentes, utilizar o Saerjinho como a única avaliação do bimestre, o que os dispensaria de elaborar outra avaliação. Ou ainda, utilizar a nota de todas as disciplinas contidas no caderno para todas elas, com a intenção de aumentar o resultado obtido pelos alunos em matérias em que costumavam ter mais dificuldade.

Os tópicos mais específicos a serem abordados no Saerjinho são relacionados em sua matriz de referência (SEEDUC, 2012b), cujos pontos para o $1^{\circ}$ ano do ensino médio podem ser vistos no Anexo 2. No entanto, uma das queixas comuns dos professores, nas entrevistas realizadas e nas conversas informais, era que alguns pontos da matriz de referência do Saerjinho não coincidiam com o Currículo Mínimo, o que faria com que o desempenho dos

\footnotetext{
${ }^{16} \mathrm{O}$ caderno de questões abrangia as disciplinas de biologia, química, história e geografia.
} 
estudantes fosse prejudicado ${ }^{17}$. Analisando-se os tópicos previstos na matriz de referência para o $1^{\circ}$ bimestre e o Currículo Mínimo, podemos ver que as críticas dos professores tinham fundamento. Indica-se que a habilidade "H02 - Identificar diferentes fontes de produção de energia: hidráulica, eólica, solar, nuclear, geotérmica, de biomassa e fóssil" - será avaliada pelo Saerjinho. Contudo, ela não refletia nenhuma das habilidades e competências indicadas no Currículo Mínimo. Esta habilidade também não é abordada no "Caderno de Atividades Pedagógicas de Aprendizagem Autorregulada" (SEEDUC, [s.d.]), outro material didático produzido pela SEEDUC e disponível para professores, via a base de dados online Conexão ${ }^{18}$.

É importante destacar também que havia graves problemas relacionados à disponibilidade e à adequação do livro didático. Em nenhuma das duas escolas havia livros o suficiente para todos os estudantes. Além disso, e ainda mais problemático, era o fato de que os conteúdos abordados pelo livro não cobriam plenamente o Currículo Mínimo, nem a Matriz do Saerjinho. Isso ocorria, pois, o currículo prescrito fora elaborado pela SEEDUC e não seguia a divisão de conteúdos de nenhuma coleção selecionada pelo Programa Nacional do Livro Didático (PNLD), conduzido pelo Ministério da Educação (MEC). Somado a isso, nenhuma das obras do PNLD era fornecida em volume único, isto é, para cada série do ensino médio havia um livro diferente e os alunos recebiam exclusivamente os livros correspondentes ao seu ano. Logo, mesmo os educandos que receberam o livro não possuíam um material que cobrisse plenamente os tópicos abordados em sala de aula.

A falta de livros fez com que diferentes estratégias fossem utilizadas pelos docentes e pelas escolas. P1 ${ }^{19}$, P3, P5 e P6 escreviam o conteúdo no quadro para que os alunos copiassem. P4 também utilizava o quadro, contudo normalmente copiava um trecho de um livro didático ou pedia para que um aluno o fizesse. Já P2 usava não só o quadro, mas também folhas de atividades, apresentações de PowerPoint e filmes. No Colégio Guarani, o diretor geral entrou em contato com outra escola em que havia sobra de livros e contratou, por sua própria iniciativa,

\footnotetext{
${ }^{17}$ Contraditoriamente, na capa do livro de matrizes de referência do Saerjinho, há a figura de um estudante segurando um livro onde se lê "Currículo Mínimo".

${ }^{18}$ Esse material nos foi cedido pelo professor P6 do colégio Passaredo.

${ }^{19}$ Os nomes verdadeiros dos professores foram substituídos pela abreviação $\mathrm{P}$ mais um número que os diferencia dos demais, respeitando, assim, o princípio do anonimato, garantido aos entrevistados no Termo de Consentimento Livre e Esclarecido (TCLE) desta pesquisa.
} 
um serviço de frete para levá-los até à escola. As coleções, contudo, não eram as mesmas, nem em número suficiente. Assim, ao final, havia turmas em que todos os alunos tinham uma coleção, turmas em que todos tinham outra, turmas em que havia ambas e turmas em que nenhum aluno havia recebido nenhum livro. Tais configurações, ainda que não resolvessem o problema em sua totalidade, eram vistas como a melhor possibilidade no cenário em que a escola se encontrava.

Feitas estas observações gerais sobre o ensino de biologia no $1^{\circ}$ ano do ensino médio na Rede Estadual de Educação, apresentaremos uma caracterização de cada uma das escolas e de seus sujeitos. Vale lembrar que estes dados só foram possíveis através da triangulação das observações, questionários e entrevistas.

\section{2}

\section{O Colégio Guarani}

O Colégio Guarani está localizado no bairro da Gávea, Zona Sul do Rio de Janeiro, próximo à PUC-Rio, shopping centers, teatros, praias e pontos turísticos da cidade, como a Lagoa Rodrigo de Freitas e o Jardim Botânico. No contexto da rede estadual de educação é considerada uma escola de grande porte, contando, de acordo com a direção da escola, com 2451 estudantes no início do ano letivo de 2014, divididos em três turnos (manhã, tarde e noite), cada um com 21 turmas de ensino médio regular e educação de jovens e adultos. Além disso, tinha 133 professores, todos concursados. Sua estrutura física é constituída de um prédio de três andares, com 21 de salas de aula, uma biblioteca, uma sala de leitura, uma sala de informática, uma sala de vídeo, pátio, duas quadras de esportes, um auditório de grande porte, um pequeno refeitório e estacionamento. Além disso, ainda há um laboratório de biologia, porém este nunca foi usado durante nosso período de observação. Todas as salas de aula possuíam aparelhos de arcondicionado e, no início de 2014, todas foram equipadas com projetores multimídia (datashow). A escola ainda investe recursos em teatro e dança, com projetos sócio-educativos e professores voluntários.

Em relação à estrutura organizacional da escola, a direção era formada por um diretor-geral, três diretores adjuntos, uma orientadora educacional, uma coordenadora de turno e uma coordenadora pedagógica. À exceção da última, que também acumulava o cargo de ensino religioso, todos os outros membros se 
dedicavam em tempo integral às suas funções administrativas e/ou pedagógicas. A coordenação de turno era responsável pelo contato mais direto com os docentes indicando as turmas para as quais deveriam ir, por exemplo - e com os alunos pedindo para que fossem para as salas. A orientação pedagógica tratava de problemas relacionados a faltas e comportamento dos estudantes. Já os diretores atuavam pontualmente nessas mesmas funções e, além disso, se reuniam com os responsáveis dos alunos e organizavam as finanças da escola. O volume de trabalho era muito grande e, com frequência, os membros da direção permaneciam além de seu horário de trabalho.

Em se tratando de outros atores e espaços escolares, a sala dos professores era um ambiente de grande movimento e agitação nos momentos antecedentes ao início das aulas e durante o recreio. O tom das conversas, em geral, era leve e com risadas. Contudo, com maior frequência, reclamações acerca da conjuntura do país, das condições de trabalho e do comportamento dos alunos podiam ser ouvidas. Via de regra, o horário do primeiro tempo de aula e do quarto - logo após o recreio - não eram cumpridos pela ampla maioria dos professores. Atrasos de quinze minutos eram os mais comuns, podendo atingir até meia hora. Tal hábito não era só usual entre os professores, mas também entre os alunos. Frequentemente, observamos metade ou mais da metade dos discentes chegando atrasados para o início das aulas, algo que foi comentado em tom de reprovação em um conselho de classe observado. Ressalte-se, porém, que neste mesmo conselho, um professor afirmou que havia alunos que se queixavam do atraso de professores. Seus colegas, em resposta, disseram que eram fatos distintos e que não deviam deixar os educandos compará-los. O desrespeito aos horários e a recusa de professores em fazer uma autocrítica, pareceu-nos um indício da insatisfação com as condições de trabalho na rede estadual de ensino. Ainda que estas condições apresentassem uma série de problemas, como aqui indicado por nós, não nos parece que sejam uma justificativa válida para violar os mínimos éticos acordados na sociedade e na comunidade escolar de que se espera que os docentes estejam presentes no momento do início das aulas, assim como os seus estudantes.

À hora do recreio, todos os alunos eram obrigados a saírem de suas salas. Por iniciativa própria, todos levavam suas mochilas para o pátio. Tal prática visava a evitar o furto de seus pertences por colegas. O clima entre a maior parte 
dos estudantes durante o intervalo, todavia, não parecia ser de desconfiança. Os jovens estudantes utilizam diversas formas de descontração no pátio, como ouvir músicas individualmente, jogar cartas ou bola. As quadras eram usadas para o futebol e o vôlei, e suas arquibancadas serviam de ponto de encontro. Alguns jovens se mantinham o tempo todo conectados a celulares e aparelhos eletrônicos, utilizando-os para ligações, trocas de mensagens, música e fotografias. $\mathrm{O}$ fone de ouvido era muito presente e, muitas vezes, compartilhado. Entretanto, isso não significa que não interagissem, já que as conversas entre os participantes dos grupos ocorriam independentemente de estarem ou não ouvindo música ou enviando mensagens.

As diferentes identidades se expressavam neste espaço, sem que necessariamente entrassem em conflito. Durante o período de observação foi possível perceber que eram poucos os estudantes isolados no pátio, mantendo-se organizados em pequenos grupos conversando e interagindo entre si. São grupos formados só por meninos, só por meninas ou mistos. Não presenciamos conflitos ou brigas, ao contrário, os jovens descreviam movimentos de aproximação e identificação com pares que compartilhavam mesmos interesses. Também eram frequentes atitudes de carinho entre namorados, muitas das vezes, beijos escondidos entre abraços, assim como o afeto e os abraços entre amigos: entre as meninas e entre meninas e meninos.

\subsection{1}

\section{Os estudantes do Colégio Guarani}

O Colégio Guarani possuía em 2014, 26 turmas de primeiro ano do ensino médio regular, sendo duas no turno da manhã, dezoito à tarde e cinco à noite. Optamos por fazer a pesquisa no turno da tarde, pois este era o que agregava a maior parte dos alunos de primeiro ano e poderia fornecer maior variabilidade de dados para a pesquisa. Devido a limitações do tempo disponível, realizamos observações de 10 turmas e das aulas de quatro dos seis professores de biologia do primeiro ano. Foram entrevistados, além dos professores observados, dez alunos (seus perfis podem ser vistos nos Anexos 6, 7 e 8). Já o questionário, foi aplicado 
a todas as turmas desta série no turno da tarde, abrangendo $399\left(n_{\mathrm{G}}\right)$ dos $628^{20}$ alunos do primeiro ano. Há que se levar em consideração, que 48 estudantes faziam parte do grupo do pré-teste e não foram incluídos na amostra final e, principalmente, a evasão dos(as)alunos(as) atingia níveis expressivos. De acordo com a escola, havia 687 alunos matriculados no primeiro ano do ensino médio no turno da tarde no início do ano letivo - uma diferença de 59 alunos, ou 8,6\%, para o começo do segundo bimestre. Embora não tenhamos os dados dos bimestres seguintes, há indícios para supor que mais alunos abandonaram a escola ao longo do ano, como por exemplo, a presença dos estudantes das turmas observadas. Ainda que as turmas tivessem em torno de 49 nomes registrados na pauta, em média, por volta de 30 alunos estavam presentes.

A escola atende, majoritariamente, jovens moradores de favelas próximas e de bairros da Zona Oeste. Os bairros dos estudantes pesquisados são apresentados na Tabela 3.1. Optamos por seguir a nomenclatura das áreas de ponderação do censo demográfico e, por isso, algumas categorias abrangem mais de um bairro. É possível perceber que mais da metade dos estudantes (60,5\%) mora em localidades da Zona Sul (Rocinha, Vidigal, São Conrado, Jardim Botânico, Gávea e Leblon). Já na Zona Oeste (Itanhangá, Jacarepaguá, Rio das Pedras, Anil, Gardênia Azul e Barra da Tijuca), moram 24,1\% dos estudantes.

\begin{tabular}{lr}
\hline Bairro & $\%$ \\
\hline Rocinha & 42,6 \\
\hline Vidigal e São Conrado & 10,8 \\
\hline Itanhangá & 7,0 \\
\hline Jacarepaguá & 6,8 \\
\hline Rio das Pedras & 5,0 \\
\hline Jardim Botânico e Gávea & 4,8 \\
Anil e Gardênia Azul & 2,8 \\
\hline Barra da Tijuca & 2,5 \\
Leblon & 2,3 \\
\hline Ausente & 1,8 \\
Outros & 13,8 \\
\hline Total & 100,0 \\
\hline
\end{tabular}

Tabela 3.1: Distribuição dos estudantes do Colégio Guarani participantes da pesquisa de acordo com o bairro em que residem ( $\left.n_{\mathrm{G}}=399\right)$.

O perfil religioso dos estudantes participantes da pesquisa pode ser visto na tabela 3.2. Primeiramente, chama a atenção o percentual de católicos $(37,6 \%)$

${ }^{20}$ Número de alunos no primeiro ano no $2^{\circ}$ bimestre, de acordo com a escola. 
bastante inferior à média da cidade $(51,1 \%)^{21}$. Ainda que seja o grupo mais frequente entre os alunos, este dado aponta para um cenário de perda de popularidade desta religião entre os jovens. Em segundo lugar, aparecem aqueles que acreditam em Deus, mas não têm religião $(28,3 \%)$, indicando a preferência de muitos dos jovens pesquisados por uma fé não institucionalizada. Em terceiro lugar, os evangélicos (de todas as denominações) somam 23,6\%, bastante próximo do percentual da cidade $(23,4 \%)$. Todos os outros grupos aparecem em porcentagens muito inferiores: em quarto lugar, os ateus somam 3,8\%, seguidos por testemunhas de Jeová (2,0\%), espíritas kardecistas (1,0\%), candomblecistas $(0,5 \%)$ e umbandistas $(0,5 \%)$. Outras denominações somaram $2 \%$ e $0,8 \%$ dos estudantes forneceram respostas incoerentes ou em branco, sendo classificadas como ausentes.

\begin{tabular}{lr}
\hline Religião & $\%$ \\
\hline Católico. & 37,6 \\
\hline Acredito em Deus, mas não tenho religião. & 28,3 \\
\hline Evangélico. & 23,6 \\
\hline Ateu. & 3,8 \\
\hline Testemunha de Jeová. & 2,0 \\
Espírita Kardecista. & 1,0 \\
\hline Candomblecista. & 0,5 \\
Umbandista. & 0,5 \\
\hline Outro. & 2,0 \\
Ausente & 0,8 \\
\hline Total & 100,0 \\
\hline
\end{tabular}

Tabela 3.2: Distribuição dos estudantes pesquisados do Colégio Guarani de acordo com seus grupos religiosos $\left(n_{\mathrm{G}}=399\right)$.

Em relação ao sexo, há igual quantidade de alunos de ambos (Tabela 3.3). Sobre a cor/raça (Tabela 3.4), 47,4\% dos estudantes se consideram pardos, 28,6\% brancos, $14,0 \%$ pretos, $6,5 \% \operatorname{amarelos}^{22}$ e 2,3\% indígenas. No que concerne à idade $^{23}$ (Tabela 3.5 e Gráfico 3.1), 0,3\% dos educandos tinha quatorze anos, $16,8 \%$ tinham quinze anos, $58,1 \%$ dezesseis, $21,1 \%$ dezessete e $3,0 \%$ dezoito.

\footnotetext{
${ }^{21}$ Ver tabelas 1.2 e 1.3 deste trabalho.

${ }^{22}$ A categoria "amarelo" no Censo Demográfico é utilizada para agrupar cidadãos de ascendência asiática. Em nossas observações, não encontramos nenhum estudante que parecesse se enquadrar nesse caso, mesma situação da alternativa "indígena". A hipótese mais plausível, baseada nas notas de campo colhidas durante a aplicação do questionário, é que os educandos que marcaram esta alternativa basearam-se na visualização da cor da sua pele, que possivelmente seria considerada "parda". Contudo, optamos por manter a autodeclaração dos participantes.

${ }^{23}$ Tomamos como data de referência 31/12/2014.
} 


\begin{tabular}{lr}
\hline Sexo & $\%$ \\
\hline Masculino & 49,6 \\
Feminino & 49,6 \\
Ausente & 0,8 \\
Total & 100,0 \\
\hline
\end{tabular}

Tabela3.3: Sexo dos estudantes participantes da pesquisa no Colégio Guarani ( $\left.n_{\mathrm{G}}=399\right)$.

\begin{tabular}{lr}
\hline Cor/Raça & $\%$ \\
\hline Pardo(a) & 47,4 \\
\hline Branco(a) & 28,6 \\
Preto(a) & 14,0 \\
Amarelo(a) & 6,5 \\
\hline Indígena & 2,3 \\
Ausente & 1,3 \\
Total & 100,0 \\
\hline
\end{tabular}

Tabela 3.4: Cor/raça dos estudantes participantes da pesquisa no Colégio Guarani $\left(n_{G}=399\right)$.

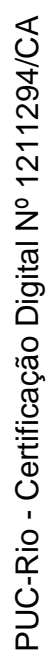

\begin{tabular}{lr}
\hline Idade (anos) & $\%$ \\
\hline 14 & $0,3 \%$ \\
15 & $16,8 \%$ \\
16 & $58,1 \%$ \\
17 & $21,0 \%$ \\
18 & $3,0 \%$ \\
Ausente & $0,8 \%$ \\
Total & $100 \%$ \\
\hline
\end{tabular}

Tabela 3.5: Idade dos estudantes participantes da pesquisa no Colégio Guarani $\left(n_{\mathrm{G}}=399\right)$.

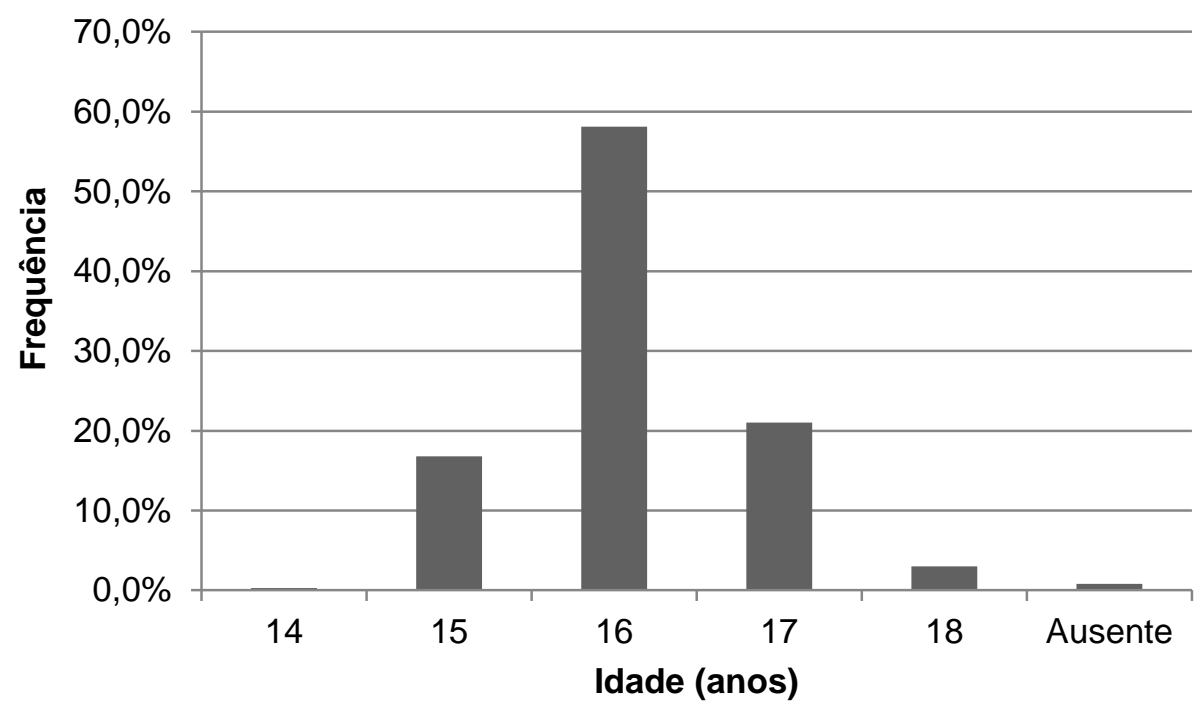

Gráfico 3.1: Idade dos estudantes participantes da pesquisa no Colégio Guarani $\left(n_{\mathrm{G}}=399\right)$. 
Em se tratando dos alunos entrevistados, seus dados estão resumidos no quadro do Apêndice 6. A aluna $\mathrm{A}^{24}$ é moradora do Anil, parda, evangélica, porém não lembrava o nome de sua igreja. A2, pardo, morador da Rocinha, é católico, tem 16 anos, frequenta a igreja de Nossa Senhora da Divina Providência, na qual estava se preparando para o sacramento da Crisma e participava do Encontro de Adolescentes com Cristo (EAC). A aluna A3, parda, também moradora da Rocinha e de 16 anos, é evangélica da Assembleia de Deus do Leblon. O aluno A4, pardo, mora na mesma favela que os dois anteriores, é católico, mas não frequenta nenhuma igreja. A5 é negro e se autodeclara ateu. Já A11 é pardo, morador da Rocinha, tem 16 anos, é católico e vai à igreja de Nossa Senhora Aparecida do Norte. A estudante A12 se declarou amarela ${ }^{25}$, é moradora de Rio das Pedras, tem 16 anos, é evangélica e frequenta a Comunidade Evangélica Filhos do Rei, na qual atua no ministério teatral, ministério de coreografia e coral e grupo jovem. A aluna A13 afirma que já frequentou escola católica, quando seguia o catolicismo, mas se afastou da religião e hoje não tem nenhuma. A aluna A14 é parda, moradora do Itanhangá, tem 15 anos e não tem religião. Por fim, A15 é morador de Jacarepaguá, tem 15 anos e é branco. Quanto à sua religião, na lista de interesse em participar da entrevista ele afirmou ser católico e evangélico. No entanto, em seu questionário, afirmou que frequenta a Comunidade Evangélica Sara Nossa Terra, onde participa do grupo de jovens.

\section{2 .2}

\section{Os professores do Colégio Guarani}

No Colégio Guarani, observamos as aulas de quatro dos seis professores de biologia do primeiro ano do ensino médio. Como discutido anteriormente, esse foi o máximo de professores que conseguimos selecionar, tendo em vista a disponibilidade de tempo do pesquisador e de modo a não prejudicar as observações na outra escola. O perfil dos docentes pesquisados foi construído a partir de uma ficha de identificação (Apêndice 7) por eles preenchida e foi sintetizado nos quadros dos Anexos 6 e 7.

\footnotetext{
${ }^{24}$ Os dados de alguns alunos estão ausentes, pois estes não estavam presentes quando da aplicação do questionário.

${ }^{25}$ Do nosso ponto de vista, poderia ser considerada branca.
} 
O professor P1 tem 43 anos de idade, 19 anos de magistério e de atuação no primeiro ano do ensino médio e cinco no Colégio Guarani. Atualmente atua em duas escolas estaduais e no ensino superior em universidade particular, segundo informação dada durante a entrevista. Possui licenciatura em Ciências Biológicas pela Universidade Federal do Rio de Janeiro (UFRJ), mestrado em Biologia Celular e Molecular pela Fundação Oswaldo Cruz (Fiocruz) e doutorado em Ciências Morfológicas pela UFRJ. Em sua entrevista, P1 diz que passou por várias denominações religiosas. "Nasceu" e foi batizado na Igreja Católica, passou pelo Protestantismo, Kardecismo e agora não tem religião. Sua atuação na escola era discreta, interagindo apenas pontualmente com outros professores de biologia. Não ocupava e, pelas informações que obtivemos, nunca ocupou nenhum cargo de coordenação ou direção. De uma maneira geral, apresentava um bom relacionamento com os estudantes, demonstrando paciência e bastante domínio do conteúdo ensinado. No entanto, foi em uma aula de P1 que observamos o conflito mais intenso acerca da evolução e origem da vida, episódio que analisaremos mais adiante. Suas aulas foram todas expositivas, utilizando apenas o quadro e, com menor frequência, ditando trechos parafraseados de um livro didático.

A professora P2 tem 42 anos de idade, 20 anos de magistério, sendo 18 como professora do primeiro ano do ensino médio e 16 anos no Guarani. Atualmente, trabalha nesta escola e mais em uma particular confessional judaica e é filiada ao Sindicato dos Professores do Município do Rio de Janeiro e Região (Sinpro). Possui licenciatura e bacharelado em Ciências Físicas e Biológicas pela Universidade do Estado do Rio de Janeiro (UERJ) e pós-graduação lato sensu em Gestão Ambiental pela Universidade Estácio de Sá (UNESA). Ela se autodeclara católica desde o nascimento, embora, ao longo de sua entrevista, diga que acredita em reencarnação e tenha recomendado um centro espírita para a professora P4, sua colega de trabalho nesta escola. Ela é uma figura muito participativa na escola, interagindo com muitos colegas professores, membros da direção, funcionários e alunos. Pode ser considerada uma das lideranças da comunidade escolar, tendo em vista que já fez parte da direção em anos anteriores e tomava à frente de pequenas tarefas coletivas do dia a dia, como organizar o espaço da sala dos professores e administrar a lista de compras de café, açúcar e lanches para a hora do recreio dos professores. Em suas aulas, procurava utilizar diferentes 
estratégias didáticas, como vídeos, aplicativos no tablet fornecido pela SEEDUC, apresentações de PowerPoint, porém, normalmente, de forma expositiva.

Já a docente $\mathrm{P} 4$ tem 58 anos de idade, 24 de magistério, aproximadamente 15 anos nesta escola e sete trabalhando com turmas de primeiro ano do ensino médio. Além de professora no Guarani, também trabalha como bióloga em um laboratório de um hospital federal. É licenciada e bacharel em Ciências Físicas e Biológicas pela Fundação Técnico Educacional Souza Marques (FTESM) e realizou duas pós-graduações lato sensu, sendo uma em Imunopatologia pela Associação Fluminense de Ensino (AFE) e outra em Análises Clínicas pelo Conselho Regional de Biologia (CRBio). Em sua ficha de identificação, quanto a sua religião, ela preencheu dizendo "Nenhuma (só creio em Deus e Jesus)". Ao longo de sua entrevista, ela afirmou que foi batizada na Igreja Católica, posteriormente, converteu-se ao pentecostalismo, fazendo parte da Igreja de Nova Vida. No entanto, atualmente, estava se aproximando do espiritismo, pois estava vendo vultos de seu falecido marido, algo para o qual não conseguia encontrar respostas, mesmo depois de se consultar com psicólogos. Durante o recreio interagia com outros colegas, sem assumir uma postura de liderança, nem ocupava nenhum cargo de coordenação. As aulas que observamos foram todas expositivas, com uso apenas do quadro e do livro didático. Em sua entrevista, P4 alegou que não utilizava outros recursos por iniciativa e financiamento próprios, pois não queria maquiar a realidade da educação estadual para seus alunos. Com isso, ela adiciona, estaria atuando no sentido de formar eleitores e cidadãos que podem mudar a sociedade ${ }^{26}$. Chamava a atenção dos alunos com frequência, ameaçando tirar-lhes pontos pelo mau comportamento, sem nunca, entretanto, tê-las levado a cabo.

O professor P7 é o mais novo entre seus colegas, tendo 31 anos de idade, sendo cinco de magistério e estava apenas há 4 meses no Guarani, seu único local de trabalho. Possui licenciatura em Ciências Físicas e Biológicas pela Universidade Federal Rural do Rio de Janeiro (UFRRJ) e não realizou nenhum estudo de pós-graduação. P7 se autodeclara budista, estando há seis anos nessa denominação, na qual atua como responsável de comunidade e líder de equipe. Em sua entrevista, diz que, quando criança, seguia a Umbanda e que sua avó tinha

${ }^{26}$ Tal argumento nos parece um uso equivocado do pensamento de Paulo Freire (2006) de libertação do oprimido, para justificar práticas pedagógicas limitadas. 
um centro desta religião em sua casa e também recebia santos. Afirma que, ainda durante a infância, fez catecismo na Igreja Católica - algo comum ao sincretismo da Umbanda - porém não gostava. Quando tinha dez anos de idade, sua família começou a frequentar a Igreja Messiânica, que ministra Johrei. No entanto, após algum tempo, seus familiares abandonaram essa denominação, sem que P7 soubesse explicar o motivo. Por volta dos quinze anos de idade, ele começou a questionar a doutrina católica, principalmente por ter de se comunicar com Deus através de padres e santos. A convite de um amigo, começou a frequentar a Assembleia de Deus, igreja evangélica pentecostal. Após desavenças com um dos pastores, afastou-se e permaneceu sem religião até os vinte e cinco anos de idade, quando se converteu, por influência de uma colega de faculdade, ao Budismo BSGI (Brasil Soka Gakkai Internacional ${ }^{27}$ ), no qual permanece até hoje. Com relação à sua atuação na escola, $\mathrm{P} 7$ se demonstrava um pouco tímido, já que era seu primeiro ano ali. Todavia, esforçava-se para estabelecer amizade com os novos colegas de trabalho. Ele atuava não só como professor de biologia, mas também de química, através de um artifício da Secretaria Estadual de Educação (SEEDUC) chamado Gratificação por Lotação Prioritária (GLP) ${ }^{28}$. Em suas aulas fez uso de estratégias didáticas distintas, como o quadro, apresentações de PowerPoint, trechos de documentários e práticas em grupo, a maior parte das vezes em caráter expositivo. Ele demonstrava ter um bom relacionamento com os educandos, denotando paciência e um tom calmo de voz.

\footnotetext{
${ }^{27}$ De acordo o site da BSGI, seu "objetivo institucional é a difusão da filosofia humanística de Nichiren Daishonin, cuja diretriz básica é felicidade plena de toda humanidade" (BSGI, 2015). Nichiren foi um monge budista, que, no século XIII, contestou as correntes existentes do Budismo e fundou o Budismo Soka Gakkai.

${ }^{28}$ A GLP podia ser requisitada por professores de uma disciplina para atuarem em outra, a fim de completarem suas horas de trabalho. Para obtê-la, o docente deveria entrar em contato com a SEEDUC e comprovar que estaria apto a atuar na outra área. No entanto, de acordo com os próprios professores, tal comprovação não exigia uma formação complementar. O professor P5 do Colégio Passaredo, por exemplo, afirmou que bastou apresentar seu histórico da graduação em que constavam disciplinas de química, bioquímica, física e biofísica para obter a GLP para ensinar química e física. Em nossa visão, tal situação é problemática, já que o docente pode vir a dar aulas de assuntos muito distantes de sua formação em biologia, como, por exemplo, eletricidade.
} 


\section{3}

\section{O Colégio Passaredo}

O Colégio Passaredo está localizado no bairro de Nossa Senhora de Fátima, próximo ao Centro de Nilópolis e à divisa deste município com Mesquita. Nilópolis faz parte da Baixada Fluminense, é conhecida pela escola de samba Beija-Flor e abriga um campus do Instituto Federal de Educação, Ciência e Tecnologia do Rio de Janeiro (IFRJ). A área do entorno da escola é composta, principalmente, por residências e pequeno comércio. Chama atenção, porém, o grande número de igrejas evangélicas na rua da escola e em uma de suas paralelas: são 16 no total, sendo 15 pentecostais ou neopentecostais e 1 batista. Há igrejas de maior porte, como uma unidade da Assembleia de Deus Vitória em Cristo, porém há outras que ocupam espaços pequenos de lojas comerciais. Nas proximidades, não há nenhuma igreja católica e há uma casa que se assemelhava a um terreiro de candomblé2 ${ }^{29}$. A presença religiosa também era visível na decoração das casas e lojas, através de imagens de santos e, principalmente, versículos bíblicos ou frases de agradecimento e exultação a Deus.

O Colégio Passaredo é de porte inferior ao Guarani, atendendo, no início do ano letivo de 2014, 1536 estudantes dos anos finais do ensino fundamental regular, ensino médio regular e educação de jovens e adultos para os anos finais do ensino fundamental e ensino médio. Além disso, contava com 108 professores regentes, sendo 96 concursados e 12 em contrato temporário, uma inspetora e um policial militar ${ }^{30}$. Sua estrutura física é constituída de um prédio maior de três andares e um menor, anexo, de dois andares. No primeiro edifício, estão localizadas 14 salas de aula, as salas da direção, secretaria e professores e o refeitório. No segundo, há mais duas salas de aula, a biblioteca e um laboratório de ciências. Tal qual no Colégio Guarani, o laboratório nunca foi utilizado durante o tempo de observação da pesquisa. Há, ainda, uma quadra poliesportiva, usada para jogos durante o recreio, além das aulas de educação física.

\footnotetext{
29 A casa possuía um muro alto, totalmente pintado de branco e com vasos de barro que o decoravam.

${ }^{30}$ Em 2012 foi estabelecido um convênio entre a Secretaria Estadual de Educação e a Secretaria de Estado de Segurança para que policiais militares atuassem em determinadas unidades escolares durante seu horário de folga (GOVERNO DO ESTADO DO RIO DE JANEIRO, 2012).
} 
É importante ressaltar que a escola sofria problemas de falta de água com certa regularidade, o que levava a direção, algumas vezes, a suspender as aulas. Outro problema recorrente, segundo depoimentos de professores e estudantes, era o grande número de pombos que se abrigavam em frestas de janelas e, principalmente, no prédio anexo, a ponto deste ser apelidado pelos alunos de “pombal”. Adicionalmente, o colégio não recebeu o número de uniformes suficiente para todos os alunos. Como não podiam frequentar as aulas com a roupa que quisessem, os educandos compravam uma versão alternativa do uniforme (ao invés da camisa cinza com detalhes em azul, esta era branca com uma versão antiga do brasão do governo do estado em azul) em uma loja a algumas quadras da escola.

Em relação à estrutura organizacional da escola, a direção era formada por uma diretora-geral, duas diretoras adjuntas, uma coordenadora pedagógica, uma orientadora educacional e um coordenador de turno, todos dedicados integralmente a essas funções. Assim como no Guarani, a coordenação pedagógica era responsável pelas questões relacionadas aos docentes. A orientação educacional tratava de problemas relacionados a faltas e comportamento dos estudantes e o coordenador de turno controlava os alunos no pátio. Já as diretoras atuavam pontualmente nessas mesmas funções e, além disso, se reuniam com os responsáveis dos alunos, organizavam as finanças da escola e lidavam diretamente com a SEEDUC. Ao longo do ano, a diretora-geral foi chamada à Metropolitana VII - unidade administrativa da Secretaria ao qual a escola estava ligada - para ser cobrada pelo baixo desempenho dos estudantes, pelos altos índices de evasão e de alunas grávidas ${ }^{31}$.

A sala dos professores era um ambiente pequeno, com alguns móveis e pintura antigos. O tom das conversas ora era leve e com risadas, ora com reclamações acerca das condições de trabalho e do comportamento dos alunos. Os atrasos entre os professores não eram tão frequentes quanto no Guarani, porém o índice de faltas era alto. Por outro lado, em se tratando dos estudantes, metade ou mais chegavam atrasados, muitos cabulavam as aulas e até mesmo iam embora -

\footnotetext{
31 No primeiro dia após o recesso da Copa do Mundo, 14/07/2014, a diretora-geral disse aos professores que a escola receberia uma fiscalização severa da SEEDUC, pois, se o ano terminasse naquele momento, $68 \%$ dos estudantes estariam reprovados, além dos altos índices de evasão e de alunas grávidas.
} 
ou, como P3 e os educandos diziam, "fugiam" - da escola após o recreio. Tais fatos eram de conhecimento da direção da escola, porém o número restrito de funcionários para o controle dos alunos fora do ambiente de sala de aula (uma inspetora e um coordenador de turno) tornava esta tarefa árdua.

Tal qual no Colégio Guarani, na hora do recreio, todos os alunos eram obrigados a saírem de suas salas. Todos levavam suas mochilas para evitar o furto de seus pertences por colegas. O clima entre a maior parte dos estudantes durante o intervalo, todavia, não parecia ser de desconfiança. Os/as jovens estudantes se distraíam de diferentes formas no pátio, ouvindo músicas, conversando ou jogando bola. O celular era a fonte mais comum de diversão, mas isso não diminuía a interação entre os alunos que demonstravam ter os mesmos gostos. Em geral, se organizavam em grupos bastante homogêneos e que dificilmente articulavam-se entre si. Não observamos episódios de violência física, ainda que, eventualmente, algumas discussões ocorressem e os alunos envolvidos fossem levados à direção para que se buscasse uma resolução ou se estabelecesse alguma punição. Assim como no Guarani, as atitudes de afeto entre namorados eram comuns.

\subsection{1}

\section{Os estudantes do Colégio Passaredo}

O Colégio Passaredo tinha em 2014, seis turmas de primeiro ano do ensino médio, todas no turno da manhã. Observamos as aulas de quatro delas, pois as outras duas permaneceram sem professor de biologia até o mês de setembro. Foram entrevistados, além dos professores observados, dez alunos (seus perfis podem ser vistos nos Anexos 6, 7 e 8). O questionário foi aplicado a todas as turmas desta série, alcançando $142\left(n_{\mathrm{P}}\right)$ dos $185^{32}$ alunos. Assim, como o Colégio Guarani, o Colégio Passaredo também possuía altas taxas de evasão. De acordo com a escola, havia 209 estudantes no primeiro ano do ensino médio no início do ano letivo - uma diferença de 24 alunos, ou 11,5\% para o começo do segundo bimestre, além de alto índice de faltas por nós observados.

\footnotetext{
${ }^{32}$ Número de alunos no primeiro ano no $2^{\circ}$ bimestre, de acordo com a escola.
} 
O Colégio Passaredo atende, majoritariamente, jovens moradores dos municípios de Nilópolis e Mesquita (Tabela 3.6). Os bairros dos estudantes pesquisados são apresentados na Tabela 3.7. É possível perceber que a maior parte dos estudantes mora em locais próximos à escola (Centro, Nossa Senhora de Fátima e Chatuba), com alguns poucos advindos de Rio de Janeiro e Queimados.

\begin{tabular}{lr}
\hline Cidade & $\%$ \\
\hline Nilópolis & 73,9 \\
\hline Mesquita & 18,3 \\
\hline Rio de Janeiro & 3,5 \\
Queimados & 0,7 \\
Ausente & 3,5 \\
\hline Total & 100,0 \\
\hline
\end{tabular}

Tabela 3.6: Distribuição dos estudantes do Colégio Passaredo participantes da pesquisa de acordo com a cidade em que residem ( $\left.n_{P}=142\right)$.

\begin{tabular}{lr}
\hline Bairro & $\%$ \\
\hline Centro/Nilópolis & 21,8 \\
\hline Nossa Senhora de Fátima/Nilópolis & 20,4 \\
\hline Chatuba/Mesquita & 14,8 \\
\hline Nilópolis ${ }^{33}$ & 14,8 \\
\hline Cabral/Nilópolis $^{\text {Anchieta/Rio de Janeiro }}$ & 9,2 \\
\hline Mirandela/Nilópolis & 2,8 \\
\hline Edson Passos/Mesquita & 2,8 \\
\hline Manoel Reis/Nilópolis & 1,4 \\
\hline Mesquita & 1,4 \\
\hline Outros & 1,4 \\
\hline Ausente & 3,6 \\
\hline Total & 5,6 \\
\hline
\end{tabular}

Tabela 3.7: Distribuição dos estudantes do Colégio Passaredo participantes da pesquisa de acordo com o bairro em que residem ( $n_{\mathrm{P}=142)}$.

$\mathrm{O}$ perfil religioso dos alunos pesquisados pode ser visto abaixo (Tabela 3.8):

\footnotetext{
${ }^{33}$ Alguns alunos declararam o nome do bairro o mesmo da cidade (caso semelhante à Mesquita, mais abaixo), possivelmente devido ao tamanho reduzido de ambos os municípios.
} 


\begin{tabular}{lr}
\hline Religião & $\%$ \\
\hline Evangélico. & 52,1 \\
\hline Acredito em Deus, mas não tenho religião. & 25,4 \\
Católico. & 8,5 \\
\hline Umbandista. & 2,1 \\
Ateu. & 1,4 \\
Candomblecista. & 1,4 \\
Espírita Kardecista. & 0,7 \\
Testemunha de Jeová. & 0,7 \\
Candomblecista e Evangélico & 0,7 \\
Católico e Umbandista & 0,7 \\
Candomblecista, Católico e Umbandista & 0,7 \\
Outro. & 4,9 \\
Ausente & 0,7 \\
Total & 100,0 \\
\hline
\end{tabular}

Tabela 3.8: Distribuição dos estudantes pesquisados do Colégio Passaredo de acordo com seus grupos religiosos $\left(n_{\mathrm{P}}=142\right)$.

Em primeiro lugar, chama a atenção o percentual de evangélicos $(52,1 \%)$ muito superior ao da cidade de Nilópolis $(33,1 \%$, agrupando-se pentecostais, de missão e não-determinados, apontado na Tabela 1.3, no capítulo 1). O grupo que se autodeclara como acreditando em Deus, mas sem religião, alcança a expressiva marca de pouco mais de um quarto dos estudantes $(25,4 \%)$, três vezes mais que o percentual de católicos $(8,5 \%)$. Pouco mais de $2 \%$ dos alunos eram umbandistas, à frente de ateus e candomblecistas (1,4\% cada). Kardecistas e Testemunhas de Jeová somavam $0,7 \%$ cada. Igual cifra foi encontrada para alunos que declararam diferentes tipos de múltiplo pertencimento, como Católico e Umbandista, Candomblecista, Católico e Umbandista e Candomblecista e Evangélico. Esta última forma é, até certo ponto, surpreendente, tendo em vista que muitas igrejas evangélicas têm uma postura combativa em relação às religiões de matriz africana (ALMEIDA, 2009; MARIANO, 1999).

Em relação ao sexo (Tabela 3.9), há uma pequena quantidade maior de meninas $(50,7 \%)$ do que de meninos $(49,3 \%)$. No que concerne à cor/raça (Tabela 3.10 ), $41,5 \%$ dos estudantes se consideram pardos(as), 25,4\% brancos(as), 20,4\% pretos(as), 9,2\% amarelos(as) ${ }^{34}$ e 2,8\% indígenas. Sobre a idade (Tabela 3.11 e Gráfico 3.2), 3,5\% tinham quatorze anos, $28,9 \%$ quinze, 26,8\% dezesseis, 20,4\% dezessete, $12,0 \%$ dezoito, $1,4 \%$ dezenove e $0,7 \%$ vinte. Há uma maior taxa de alunos com mais de 16 anos nesta escola do que no Guarani, o que indica a existência de maior distorção idade-série. Não é possível afirmar somente com

\footnotetext{
${ }^{34}$ Como dito anteriormente, não observamos nenhum aluno de origem asiática ou indígena, sendo o mais provável que estes se guiaram pela sua própria impressão da cor de sua pele.
} 
base nesses dados, todavia, se o Colégio Passaredo reprova mais estudantes do que o Guarani. Podemos dizer apenas que mais estudantes que já repetiram alguma série estudam no Passaredo do que no Guarani.

\begin{tabular}{lr}
\hline Sexo & $\%$ \\
\hline Feminino & 50,7 \\
Masculino & 49,3 \\
Total & 100,0
\end{tabular}

Tabela 3.9: Sexo dos estudantes participantes da pesquisa no Colégio Passaredo $\left(n_{\mathrm{P}}=142\right)$.

\begin{tabular}{lr}
\hline Cor-Raça & $\%$ \\
\hline Pardo(a) & 41,5 \\
Branco(a) & 25,4 \\
Preto(a) & 20,4 \\
Amarelo(a) & 9,2 \\
Indígena & 2,8 \\
Ausente & 0,7 \\
Total & 100,0 \\
\hline
\end{tabular}

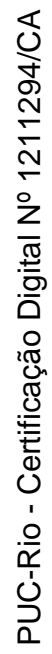

Tabela 3.10: Cor/raça dos estudantes participantes da pesquisa no Colégio Passaredo $(\mathrm{nP}=142)$.

\begin{tabular}{lr}
\hline Idade & $\%$ \\
\hline 14 & 3,5 \\
15 & 28,9 \\
16 & 26,8 \\
17 & 20,4 \\
18 & 12,0 \\
19 & 1,4 \\
20 & 0,7 \\
Ausente & 6,3 \\
Total & 100,0 \\
\hline
\end{tabular}

Tabela 3.11: Idade dos estudantes participantes da pesquisa no Colégio Passaredo $(\mathrm{nP}=142)$. 


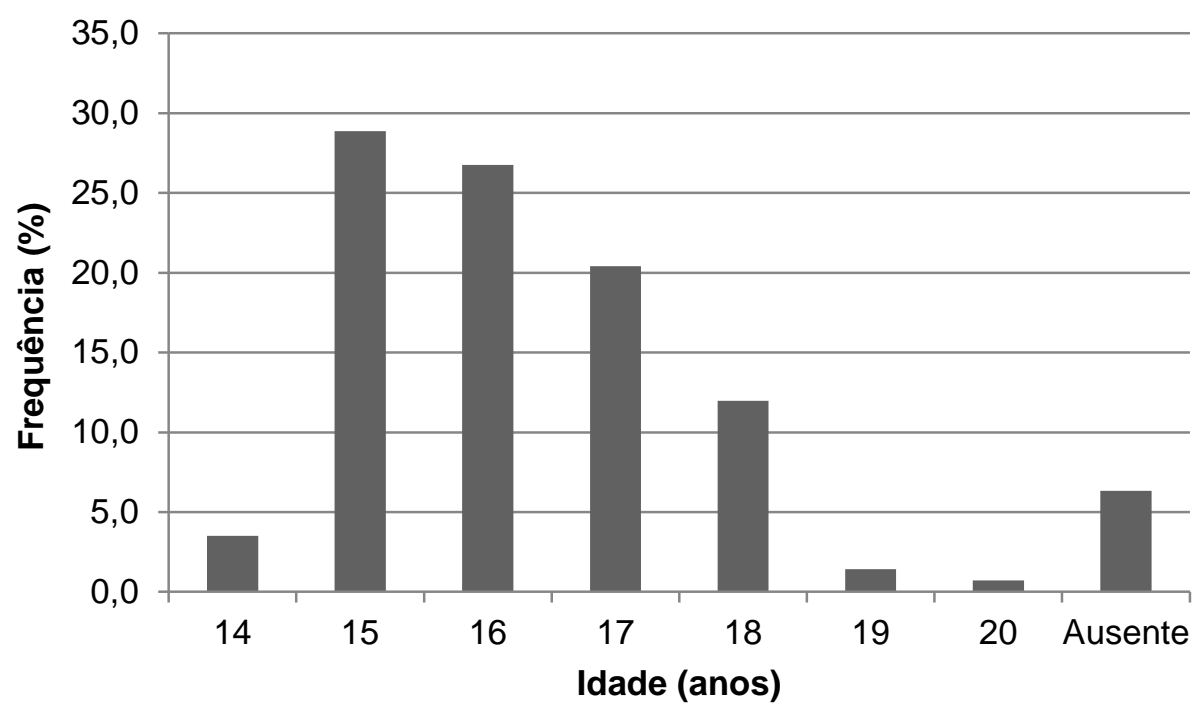

Gráfico 3.2: Idade dos estudantes participantes da pesquisa no Colégio Passaredo $(\mathrm{nP}=142)$.

Com relação aos alunos entrevistados, seus dados estão resumidos no Apêndice 6. A estudante A6 é moradora da Chatuba, em Mesquita, é parda, evangélica, no entanto, atualmente, estava afastada da igreja, embora, em sua entrevista, ainda demonstrasse intensa vontade de voltar a frequentá-la. A aluna A7 é moradora do Centro de Nilópolis, parda, 16 anos, evangélica da igreja Ministério Visão de Glória, onde atua no ministério de louvor ${ }^{35}$. Ela estava noiva e estudava livros evangélicos sobre o casamento durante as aulas. $\mathrm{O}$ aluno A8 também é morador do Centro de Nilópolis, tem 17 anos, se declara branco e católico, porém não frequenta nenhuma paróquia atualmente. Já A9 é moradora do bairro de Nossa Senhora de Fátima, tem 16 anos, é parda, evangélica e frequentadora do Ministério Shekinah ${ }^{36}$. A10 também é morador de Nossa Senhora de Fátima, tem 18 anos, é negro e se declarou sem religião, ainda que, em sua entrevista, tenha dito que lê a Bíblia quase diariamente e se espelha muito em seu irmão, que é evangélico. A16 mora no Centro de Nilópolis, tem 17 anos, se autodeclara amarelo ${ }^{37}$, é evangélico e frequenta a Igreja Restaurando Vidas. A17, por sua vez, é moradora de Nossa Senhora de Fátima, tem 14 anos, se declarou indígena $^{38}$ e evangélica da Assembleia de Deus Vivendo em Santidade. A aluna A18 é moradora da Chatuba, tem 16 anos, é parda e evangélica da Igreja Pentecostal Deus Trabalha na sua Vida, na qual participa do grupo jovem

\footnotetext{
${ }^{35}$ Grupo responsável pelos cantos e músicas em cultos e celebrações.

${ }^{36}$ Do hebraico, "presença de Deus".

${ }^{37}$ Do nosso ponto de vista, poderia ser considerado branco.

${ }^{38}$ Do nosso ponto de vista, poderia ser considerada parda.
} 
Guerreiros de Cristo. O aluno A19 é branco, evangélico e frequentador da igreja Paz e Vida. Finalmente, A20 mora em Nossa Senhora de Fátima, tem 15 anos, é branca, evangélica e frequentadora da Assembleia de Deus Vitória em Cristo. Ela esteve ausente nos primeiros meses do ano letivo, devido ao nascimento de seu filho.

\subsection{2}

\section{Os professores do Colégio Passaredo}

No Colégio Passaredo, observamos as aulas de três professores (P3, P5 e P6) os quais atuavam em quatro das seis turmas de primeiro ano da escola. No início do ano letivo, havia dois docentes nesta série, P6 (que atuava na turma 1004) e outra professora com a qual não chegamos a estabelecer contato (que atuava nas turmas 1001, 1002 e 1005). Esta possuía vínculo de contrato e, após as duas primeiras semanas, foi substituída por P5. Em junho, pouco antes do recesso para a Copa do Mundo, P3 retornou ao trabalho com o fim de sua licença maternidade e assumiu as turmas de P5. Tal fato o surpreendeu, já que desconhecia que havia outra professora a quem estaria, teoricamente, substituindo. Com a volta de P3, ele deixou de atuar em biologia no primeiro ano, assumindo aulas de química e física no ensino médio, via GLP, e ciências no ensino fundamental. Enquanto isso, as turmas 1003 e 1006 - esta última criada no final do primeiro bimestre -, permaneceram sem professores de biologia até o mês de setembro e, por esse motivo, não as acompanhamos. Os perfis de P3, P5 e P6 são resumidos nos Anexos 6 e 7 .

A professora P3 tem 35 anos de idade, nove anos de experiência no magistério, mesmo tempo que trabalha nesta escola, sendo cinco como professora do primeiro ano do ensino médio. Atualmente, trabalha no Passaredo e em uma escola municipal do Rio de Janeiro. Possui licenciatura em Ciências Biológicas pela UERJ, tendo se formado em 2004 e pós-graduação lato sensu em Ensino de Ciências por esta mesma universidade, em 2006. Ela se declara como tendo sempre sido católica e, ainda que hoje não consiga frequentar missas tanto quanto gostaria, afirma manter sua fé e procura criar seu filho nos preceitos dessa religião. No passado, atuou como catequista e completou o curso "Luz e Vida", que aprofunda os conhecimentos necessários para atuar como catequista. Sua 
atuação na escola era bastante ativa, em constante diálogo com outros colegas professores e membros da direção. Procurava ter um bom relacionamento com os estudantes, os quais sempre procurava chamar pelo nome e muitos já conhecia de anos anteriores, quando atuava no ensino fundamental. Todas as suas aulas observadas foram expositivas e centradas em sua figura, intercaladas por algumas perguntas abertas aos estudantes e outras retóricas.

O professor P5 tem 32 anos de idade, sete deles como professor e atuando no primeiro ano do ensino médio. Começou a trabalhar no Passaredo em 2014 e dava aulas em mais quatro escolas. Possui os títulos de licenciado e bacharel em Ciências Biológicas pela Universidade Iguaçu (UNIG) obtidos em 2008 e pósgraduação lato sensu pela mesma instituição, no mesmo ano. Além de sua atividade profissional, faz parte da Juventude do Partido Trabalhista Brasileiro (PTB) de Nilópolis. Em relação à sua religião, P5 declara ter sempre sido católico, porém diz não frequentar missas tanto quanto outrora, quando chegou a atuar como catequista. Na escola, se mostrava disponível a estabelecer amizade com outros professores, ainda que de forma lenta, devido a seu pouco tempo ali. Procurava manter um bom relacionamento com estudantes, no entanto, não se preocupava em exigir um bom comportamento o tempo todo. As suas aulas observadas foram todas expositivas e, com frequência, ele apenas escrevia no quadro e sentava-se à sua mesa pelo restante do tempo.

Já P6 tem 33 anos de idade, nove de magistério, seis no Passaredo e três como professor do primeiro ano do ensino médio. Atualmente, além do colégio pesquisado, trabalha em uma escola do município do Rio de Janeiro. Possui licenciatura e bacharelado pela Universidade Santa Úrsula (USU), obtidos em 2004 e pós-graduação lato sensu em Gestão da Biodiversidade pela Escola Nacional de Botânica Tropical do Jardim Botânico do Rio de Janeiro (ENBTJBRJ), de 2007. Ele é batista desde os oito anos de idade, contudo, afirma que está afastado de sua religião, embora continue acreditando em seus preceitos. Quando frequentava os cultos, atuava no ministério do louvor de sua igreja, como músico da banda. No Colégio Passaredo, mantinha conversas com vários colegas professores e com a direção, embora não se constituísse como uma liderança. Seu relacionamento com os alunos era bom, na maior parte do tempo, todavia presenciamos algumas discussões mais ríspidas, relacionadas, principalmente, à indisciplina em sala de aula. Todas as suas aulas foram expositivas, utilizando 
apenas o quadro para escrever a lição do dia, baseando-se, frequentemente, no "Caderno de Atividades Pedagógicas de Aprendizagem Autorregulada" (SEEDUC, [s.d.]), mencionado anteriormente.

Comparando-se os perfis dos professores das duas escolas, podemos perceber que há maior rotatividade de docentes na escola nilopolitana do que na carioca, já que os que atuam nesta são, em sua maioria, mais velhos e com mais tempo de trabalho na escola, bem como a existência de docentes contratados na primeira e sua inexistência na segunda. Além disso, os professores do Colégio Guarani são formados em universidades de maior prestígio do que os do Colégio Passaredo.

\section{4}

\section{A presença religiosa nas escolas pesquisadas}

Além das frequências das religiões entre os estudantes, apresentadas anteriormente, a presença religiosa podia ser vista de outras formas nas escolas, a saber: (i) o ensino religioso; (ii) símbolos religiosos; (iii) músicas gospel; (iv) fiéis pregando em frente e no interior da escola. Ainda que todos esses tipos tenham sido observados ao longo da pesquisa, a maneira como se faziam presentes variou entre os dois colégios e os sujeitos de pesquisa lhes conferiam valores distintos.

A primeira delas se dá através da disciplina de ensino religioso. Esta forma institucionalizada da religião na escola, prevista no parágrafo primeiro do artigo 210 da Constituição Federal de 1988 e no artigo 33 da Lei de Diretrizes e Bases da Educação de 1996, foi regulamentada pela lei estadual 3459 de 2000, de autoria do deputado estadual, católico, Carlos Dias e outorgado pelo governador, evangélico, Anthony Garotinho (CAVALIERE, 2007). A legislação estadual prevê que o ensino deve ser realizado na modalidade confessional - isto é, quando a doutrina de uma única religião é abordada - e que as escolas são obrigadas a oferecer esta disciplina. No entanto, a matrícula dos alunos é facultativa, seguindo a vontade de seus responsáveis.

No Colégio Guarani, havia aulas previstas para 12 das 18 turmas do primeiro ano do turno da tarde, porém, dos dez estudantes entrevistados, apenas um sabia da existência dessa disciplina. De acordo com a própria professora de ensino religioso, apenas duas aulas haviam sido ministradas para cada turma até o 
final do mês de julho, pois ela não tinha tempo suficiente devido ao fato de acumular o cargo de coordenadora pedagógica. Ela é católica, diz "viver" sua religião, é pedagoga, possui pós-graduação lato sensu em teologia pela Faculdade São Bento, é administradora e está concluindo graduação em história. Afirmou que o ensino religioso na escola não é confessional, tratando várias religiões, em uma abordagem histórica. Acrescenta, ainda, que em suas aulas havia alunos católicos, evangélicos, espíritas e aqueles que seguiam "seitas satânicas", embora não tenha dado mais detalhes sobre o que seriam. Em sua visão, todos os alunos devem aprender sobre religião porque, mesmo que não tenham nenhuma, a religião está presente na vida deles. Além disso, afirma que "muitos estão perdidos" e, por isso, recomenda-lhes que "procurem qualquer religião, mas que procurem alguma". Dá como exemplo o caso de um grupo de estudantes do colégio que foi flagrado com drogas em uma praça próxima à escola por policiais, que os levaram até a direção ${ }^{39}$. Os responsáveis foram chamados e a professora lhes disse, como alguns eram evangélicos, que rezassem com seus filhos.

No Colégio Passaredo, verificam-se muitas semelhanças com relação à estrutura do ensino religioso. Nesta escola, a disciplina era ministrada por uma professora batista, casada com um pastor, formada em letras português-francês e estava no $5^{\circ}$ período da faculdade de psicologia à época da pesquisa. Ela disse que o ensino religioso era "confessional plural", enfatizando o respeito a todas as religiões e a discussão de valores. Toda aula ela lia um trecho da Bíblia e procurava atender os interesses dos alunos de estudar algumas crenças específicas, como a maçonaria e a mitologia grega. Esta professora ressaltou que o ensino religioso não era obrigatório e que precisava agrupar alunos de várias turmas para conseguir o número suficiente de estudantes para a aula, algo que, no ano letivo de 2014, só havia conseguido para o $7^{\circ}$ ano do ensino fundamental. Em sua visão, "70\% dos alunos são evangélicos". Ela diz, ainda, que uma vez, uma aluna havia feito o santo no candomblé e, por isso, havia raspado os cabelos, o que a fez sofrer provocações de seus colegas, ou "bullying", em suas palavras. A professora afirmou que atuou, em conjunto com a escola, para intervir nesse caso, protegendo a aluna.

\footnotetext{
${ }^{39}$ Posteriormente, uma professora de artes nos contou que esses alunos foram transferidos para outras escolas.
} 
O ensino religioso no Brasil é alvo de muitas críticas por parte de pesquisadores (CAPUTO, 2012; CAVALIERE, 2007; CUNHA, 2007, 2009) que apontam que ele não contribui para a construção da tolerância religiosa e que, muitas vezes, embora seja facultativo, as direções das escolas omitem tal fato a fim de que os estudantes não deixem de assistir às aulas e fiquem ociosos. Em relação à primeira alegação, como não acompanhamos estas aulas em nenhuma das escolas, não possuímos dados suficientes para fazer qualquer consideração. Já sobre uma possível omissão com relação à não-obrigatoriedade da disciplina, nossas observações indicam que os estudantes e responsáveis, aparentemente, estavam cientes disso. No Colégio Passaredo, por exemplo, no ato da matrícula, os responsáveis deviam preencher uma ficha na qual constava a pergunta se gostaria que o educando assistisse a essas aulas.

Há um tom de desconfiança na fala das professoras de ensino religioso e nas de coordenadoras com as quais conversamos sobre esse assunto. A presença de um pesquisador na escola, fazendo perguntas sobre ensino religioso, fazia com que todas elas tivessem certo padrão em suas respostas: (i) enfatizavam que o ensino religioso não era obrigatório, (ii) que atendia a todas as religiões e (iii) que procuravam falar mais de valores do que propriamente da doutrina. Segundo nossa interpretação, em relação ao primeiro ponto, essa resposta vinha com um tom defensivo, talvez por conta de terem conhecimento que tal assunto é polêmico. O segundo aspecto possivelmente se deve a um desejo de mostrar a escola como "politicamente correta" e atendendo à diversidade de crenças, algo presente no senso comum como positivo. Já o terceiro, baseia-se em uma concepção de que a religião é a principal fonte de valores da sociedade ${ }^{40}$. Uma vez que em seus relatos sobressaem as menções a religiões cristãs, é questionável a alegação de que abordam a diversidade religiosa e nos faz problematizar que valores seriam esses que os estudantes não possuem e que a disciplina de ensino religioso poderia lhes oferecer.

A segunda forma pela qual pudemos perceber a presença religiosa na escola são os símbolos religiosos. Além do uso pessoal de crucifixos, joias e vestimentas com temática religiosa por parte de estudantes e professores, foram

\footnotetext{
${ }^{40}$ Essa visão pode ser vista, em certa medida, na legislação do município do Rio de Janeiro para o ensino religioso que prevê que os estudantes cujos pais decidam que não devem assistir às aulas de religião, deverão ter aulas de valores (SME, 2011).
} 
observadas imagens e mensagens com elementos cristãos em ambas as escolas. Na sala do Serviço de Orientação Pedagógica do Colégio Guarani, havia uma imagem de Nossa Senhora de Fátima e outra de Nossa Senhora Aparecida expostas em uma estante. A professora de ensino religioso e coordenadora pedagógica afirmou que tais imagens foram trazidas por ela. Ela disse ter trazido Bíblias também para esta sala, seu local de trabalho, e que a presença desses símbolos religiosos fazia com que os pais, principalmente os evangélicos, se sentissem mais à vontade. Além disso, ela afirmou que a professora de ensino religioso anterior costumava organizar uma missa ao final do ano voltada para a comunidade escolar. Ela, por sua vez, tinha planos para uma organização ecumênica, mais ampla, com a presença de um padre e de um pastor. Já no Colégio Passaredo, por iniciativa de uma das diretoras adjuntas, muitas mensagens estimulando "o amor ao próximo", a "Deus" e ao "Senhor", foram afixadas nas paredes da sala da direção ${ }^{41}$. Outros cartazes de autoria de alunos do ensino fundamental sobre a Páscoa puderam ser vistos afixados em mural, próximo à época deste feriado religioso, mas em um local de pouca circulação no pátio.

É interessante notar que, nas duas escolas, a maior parte dos símbolos religiosos não estavam localizados em salas de aula, ou em ambientes de uso compartilhado, mas sim na sala do Serviço de Orientação Pedagógica (Guarani) e da direção (Passaredo). Além disso, essas manifestações eram resultado da ação de determinados atores escolares e não aparentavam ser uma política institucional dos colégios. Tais indícios podem indicar que estes atores reconhecem que esses símbolos podem levantar polêmicas e os utilizam nos espaços que acreditam ser os mais "seus" na escola. Ou seja, privatizam, conscientemente ou não, os escritórios em que trabalham e, longe dos olhares da maior parte dos frequentadores da instituição de ensino, sentem-se mais seguros para manifestar suas crenças religiosas. Enquanto Giumbelli (2014) argumenta que a presença explícita de símbolos religiosos em repartições públicas é defendida com base no argumento de que, mais do que representar uma religião em específico, fazem parte da cultura nacional brasileira, em nosso caso, sua presença parcialmente

\footnotetext{
${ }^{41}$ Um único cartaz de iniciativa da direção com um texto explicitamente religioso foi visto fora desta sala. Contudo, já no dia seguinte, havia sido retirado. Não sabemos determinar quem o removeu.
} 
velada parece indicar o oposto: é um símbolo unicamente religioso e, neste espaço, estaria "protegido" de possíveis censuras de outrem. Independentemente de tais considerações, essa atitude nos parece uma violação da laicidade da escola enquanto espaço público, já que a religião de um determinado grupo está sendo privilegiada em detrimento de outras.

A terceira forma de manifestação religiosa por nós observada ocorreu exclusivamente no Colégio Passaredo. Já no segundo semestre, os estudantes reativaram a rádio da escola e, durante o recreio, colocavam músicas para tocar através dos alto-falantes do pátio, a maioria delas, gospel. Esta atitude dos alunos também levanta questionamentos sobre a laicidade da escola: uma vez que a rádio é de responsabilidade dos educandos e não da escola, enquanto instituição pública, trata-se, de fato, de uma violação da laicidade? Se músicas de outros grupos religiosos fossem tocadas, eliminando-se - ou ao menos se atenuando - o privilégio de uma sobre as outras, esta escola poderia ser considerada laica? Uma vez que estas questões fogem do foco desta pesquisa, não podemos respondê-las nesse momento. Frisamos, contudo, que fatos como esse e a presença de símbolos religiosos indicam que a relação entre escola e religião é mais complexa do que apenas os debates em torno do ensino religioso(ANDRADE; TEIXEIRA, 2014).

Igualmente à terceira, o quarto tipo de expressão religiosa que observamos tomou lugar apenas no colégio de Nilópolis. Uma senhora idosa costumava circular pela rua da escola, bradando de forma desconexa frases sobre a Bíblia, Jesus Cristo e Deus. Certa vez, em um momento em que a porta da escola estava aberta e nenhum funcionário fazia o controle da entrada e saída de pessoas, ela conseguiu entrar e acessar o pátio. Uma das diretoras-adjuntas foi até ela e, de maneira educada e respeitosa, procurou retirá-la. Após certa resistência, a senhora, que não parou de gritar um momento sequer, saiu para a rua e continuou sua caminhada e pregação em voz alta. O episódio provocou o riso de estudantes, professores e funcionários que já estavam habituados àquela presença nos arredores da escola e a chamavam de "fanática". De acordo com a inspetora da escola, essa mesma senhora tinha o costume de fazer suas pregações também aos finais de semana, nas primeiras horas da manhã, irritando a vizinhança. Ainda que de uma maneira que a comunidade escolar pode julgar irônica, a religião por vezes "invade" a escola e lidar com ela e com os fiéis pode ser delicado, como este episódio evidencia. 
É preciso destacar ainda, que a presença e influência evangélica na escola nilopolitana é maior do que na carioca não apenas pelo maior índice de estudantes desse grupo religioso $(52,1 \%$ contra $23,6 \%$, como dito anteriormente), mas também pelo entorno da escola. Retomando dados que apresentamos ao longo do texto, nas proximidades do Colégio Passaredo havia 15 igrejas evangélicas pentecostais - sendo uma delas exatamente em frente à escola - e mais uma batista, enquanto que nos arredores do Colégio Guarani, não havia nenhuma igreja evangélica. Da mesma maneira, apenas no Passaredo ouvimos músicas gospel sendo executadas.

\section{5}

\section{Uma tentativa de síntese}

Neste capítulo, procuramos descrever o campo e sujeitos de pesquisa e promover a análise de alguns fatos observados. Nesse sentido, pesquisamos duas escolas estaduais do Rio de Janeiro, uma localizada na capital, Colégio Guarani, e a outra em Nilópolis, Colégio Passaredo. A escolha desses ambientes se deu em função da distribuição de evangélicos nas duas cidades - mais na da Baixada Fluminense do que na Zona Sul da cidade do Rio de Janeiro - padrão que se mostrou ainda mais intensificado entre os estudantes pesquisados, o que nos indica que a presença e a influência evangélica no Colégio Passaredo eram possivelmente maior do que no Guarani.

Os professores pesquisados possuem perfil religioso razoavelmente diversificado o que, como veremos adiante, impacta diretamente sobre a maneira como veem as relações entre evolução e criacionismo e isso implica suas práticas pedagógicas. Os alunos entrevistados foram escolhidos intencionalmente para a pesquisa, após as observações e a aplicação dos questionários, e também apresentam certa diversidade de crença, ainda que não tenhamos procurado estabelecer uma amostra estatisticamente representativa.

No próximo capítulo, analisaremos mais detalhadamente as concepções dos professores participantes da pesquisa acerca do criacionismo e da evolução. Como veremos, os docentes que possuem uma religião estabelecem formas complexas e diferentes entre si para solucionar possíveis conflitos teóricos entre a teoria evolutiva e suas crenças religiosas. 


\section{4. \\ CONCEPÇÕES DOS PROFESSORES SOBRE CRIACIONISMO E EVOLUÇÃO}

Os professores pesquisados apresentam diferentes formas de lidar com o criacionismo e a evolução. P1 e P7 não acreditam no criacionismo bíblico e possuem visões que estão mais próximas da científica do que de crenças religiosas. Já os outros cinco professores procuram maneiras de conciliar essas duas formas de pensamento, tal como já havíamos demonstrado em nossa pesquisa de mestrado (TEIXEIRA, 2012). No entanto, eles usam diferentes argumentos para justificar sua posição, apontando limitações, do seu ponto de vista, ora do conhecimento científico, ora do conhecimento religioso. Dada essa diversidade de concepções dos participantes da pesquisa, analisaremos cada caso em separado e, ao final, tentaremos identificar semelhanças e distinções entre eles (a lista de temas e códigos utilizados na análise podem ser vistos no Apêndice 9).

\section{1 \\ Concepções de P1 sobre evolução e criacionismo: verdade e conforto na evolução}

Como descrevemos no capítulo anterior, P1 se declara sem religião e, pelo conteúdo de sua entrevista, não acredita em um Deus como agente criador. Nesse sentido, sua visão da relação entre evolução e criacionismo é mais direta e menos complexa do que a dos professores que possuem uma crença religiosa, como veremos mais adiante. P1 distingue claramente evolução de criacionismo, identificando a primeira com relacionada à natureza e à realidade e o segundo, consequentemente, como algo falso. Ele afirma que após passar por muitas religiões e viver um momento de conflito pessoal durante o início da faculdade, afastou-se das crenças religiosas e diz que entender a realidade lhe trouxe mais conforto e sentido à vida do que acreditar em uma entidade transcendental. Ainda assim, diz que não se incomoda em falar de Deus, pois, Ele não seria uma figura 
concreta de aparência humana, como para o cristianismo, mas sim uma sensação boa. Sua visão pode ser resumida no mapa conceitual abaixo (Figura 4.1).
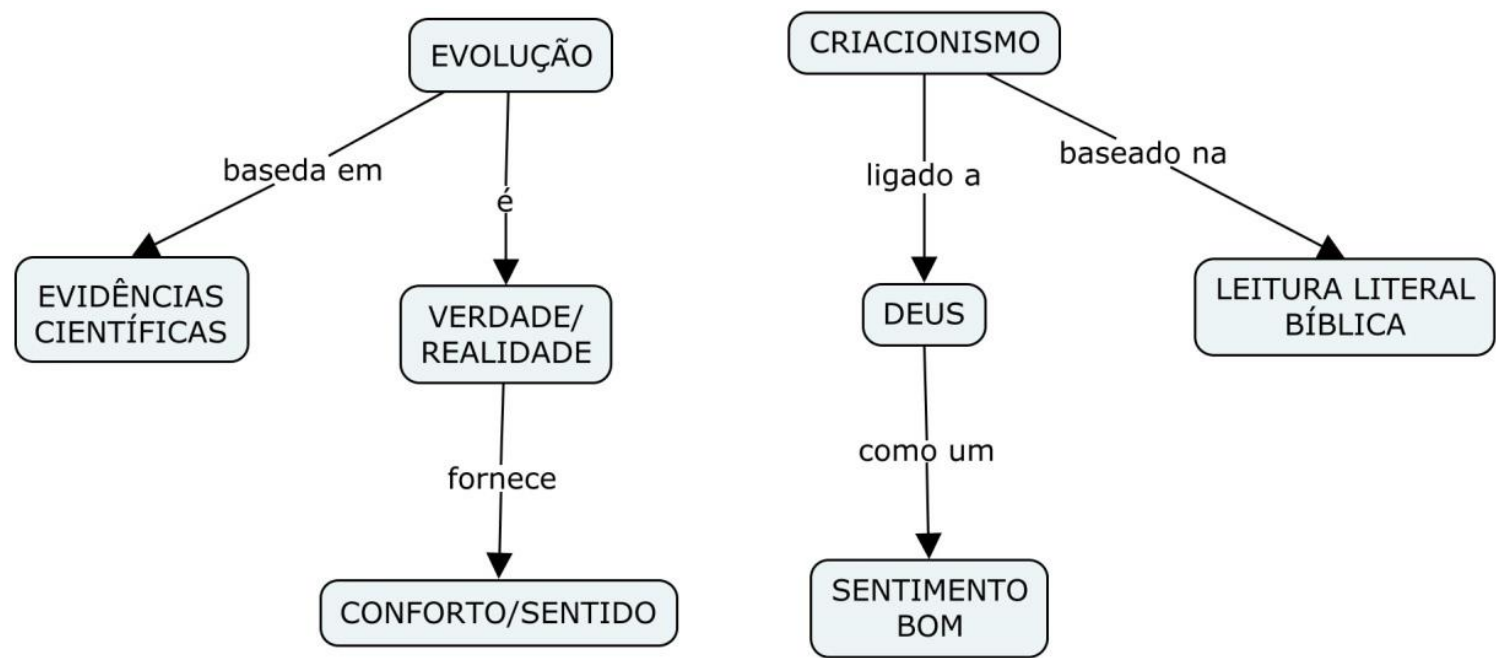

Figura 4.1: Concepções de P1 sobre evolução e criacionismo.

Primeiramente, cabe destacar que P1 identifica o criacionismo com a tradição judaico-cristã e diz que ensina criacionismo antes da evolução para, ao contrastar os dois, evidenciar que o primeiro não é verdade e a última sim:

\begin{abstract}
$P^{42}$ : Pensando agora no criacionismo. Quando a gente fala de criacionismo o que te vem mais forte à cabeça?

P1: Criacionismo é a tradição judaico-cristã. A ideia de que Deus... O ato de criação. As espécies estão ali e se mantêm do jeito, conforme foi no momento da criação. [...]

$P:$ E você ensina o criacionismo?

P1: Ah, sim, eu tenho que falar do criacionismo para poder falar do evolucionismo. Eu tenho que dizer que foi dessa maneira, para falar dos fósseis depois, eu tenho que falar do criacionismo. Aí nesse momento dá um...A turma sente, aí dá pra ver.

P: Você fala isso? Você disse que tem que falar do criacionismo para falar da evolução. Por quê?

P1: Porque.... As espécies são as mesmas? Não são. Então, o estudo dos fósseis já veio mostrando. Então, eu localizo qual século isso surgiu. Darwin, como foi o tempo que ele levou para ele publicar o livro dele. Então, você tem uma sociedade que pensa de uma maneira e vem surgindo os avanços, as pessoas que vão repensando, vão avaliando, vão observando e vê que a realidade não é em acordo com o criacionismo. [...] Por isso que eu preciso da mutação. Preciso convencer. Preciso fazer o link entre DNA, RNA, proteína e características. Eles têm que entender que proteína tem relação com características, mas para isso tem que chegar a mutação, tem que falar da mutação, chegar no DNA, eu tenho que falar legal disso aí, de uma maneira que eles sintam isso.
\end{abstract}

Neste depoimento, P1 inicia dizendo que, ao pensar sobre o criacionismo, se remete a Deus atuando na criação, conforme descrito pelo judaísmo e cristianismo. Quando questionado se ensina o criacionismo, ele diz que é preciso falar do criacionismo para abordar a evolução e que, no momento em que

\footnotetext{
${ }^{42}$ Pesquisador.
} 
contrasta ambos, a turma "sente", isto é, ficaria impactada pelo que ele está falando. Ainda que ele afirme ensinar o criacionismo, isso não significa que ele o trate como verdadeiro. Ele argumenta que as evidências científicas (citando explicitamente os fósseis) indicam que o criacionismo não é verdade, uma vez que as espécies não são as mesmas desde o surgimento da vida (fixismo). P1, então, acrescenta que as pesquisas foram se desenvolvendo ao longo do tempo, até o ponto em que os cientistas perceberam que "a realidade não é de acordo com o criacionismo". Por fim, refere-se novamente ao uso de evidências científicas para fundamentar a teoria evolutiva e para que este conteúdo não só fique mais claro para os estudantes, mas também para convencê-los. Embora ele não desenvolva o que quer dizer com convencimento, tal palavra indica persuasão, o que, possivelmente, reflita seu desejo de modificar as crenças dos estudantes, também reforçado pela expressão "que eles sintam isso", ao final do trecho. Um episódio de conflito com uma aluna em uma de suas aulas - fato que analisaremos em capítulos futuros -, faz-nos acreditar que seu objetivo esteja mais próximo de um desejo que os alunos abandonem a crença no criacionismo e adotem uma visão em maior sintonia com a evolução. Tal perspectiva seria, inclusive, condizente com a própria trajetória pessoal de P1, que afirmou ter sido religioso, ter entrado em crise com suas crenças e ter encontrado mais sentido nos estudos científicos.

Uma vez que P1 havia dito já ter passado por diferentes religiões, perguntamos-lhe se, no passado, havia vivido algum tipo de dificuldade em conciliar seus estudos com suas crenças religiosas:

\begin{abstract}
P: Você falou que passou por diversas religiões. Você teve alguma dificuldade na sua formação, de conciliar seus estudos em biologia com sua religião?

P1: Vem o conflito, né? [Reduz o tom de voz]. Chegou uma hora que eu não acreditava em nada, cheguei nesse ponto, que não acreditava em nada... Me sentia um imbecil. Me sentia um imbecil... [...] Houve uma transição. Nessa época, eu era espírita, mas eu me envolvia, não ficava de fora olhando não, eu entrava de cabeça, ia ler. Aí as coisas começavam a sedimentar, o que eu aprendia lá [faculdade] e vi que...Era um equívoco... [...] Mas para mim, eu tinha que buscar uma outra forma de lidar com questões... De existir, morrer, acabou, e equilibrar isso. Eu achei impossível equilibrar isso. Esse é o medo: não ter continuidade. Mas a ideia da falta de continuidade foi tão clara, quando eu comecei a estudar, me pareceu tão óbvio. Eu comecei a achar absurdo essas crenças todas, que não servem para mim.
\end{abstract}

O professor começa sua resposta dizendo que sentiu um conflito. A mudança de seu tom de voz talvez indique dificuldade de lidar com o tema. O que fica mais evidente com as declarações de que "não acreditava em nada" e de que se "sentia um imbecil". Depois desse momento, houve um período de transição, 
em que passou a questionar as crenças espíritas que tinha, por causa do que aprendia na faculdade. É preciso ressaltar que esses questionamentos se deram não só em função do estudo da teoria evolutiva, mas também pelo medo do que aconteceria após a morte. Foi então, pelos seus estudos acadêmicos, que ele afirma ter superado esses temores. Neste sentido, P1 abandonou os conhecimentos de sua religião para adotar novos argumentos, baseados, desta vez, na ciência. Tal movimento parece se aproximar de uma secularização individual, que, de acordo com Berger (2001) e Evans (2011), é exceção na sociedade. P1 vai além e afirma que a realidade lhe ofereceu "mais equilíbrio" do que outros artifícios:

P1: Tive conflitos sim, me adaptar a isso foi complicado, e descobrir uma humanidade dentro disso. A realidade equilibra muito mais do que qualquer artifício. [...]

P: Explica isso um pouco melhor. Você tava falando que a realidade equilibra mais, o que quer dizer?

P1: A realidade como é, dentro da evolução, entender a evolução dos seres vivos, entender que existe uma mutação ali, as características, a seleção natural. A gente é um animal mesmo. Eu descobri que eи sou um animal, eи tenho uma característica, projetar e articular o pensamento, é uma característica. Entender isso como uma característica, entender a fisiologia disso, é clara, quando você começa a estudar sistema nervoso. [...]. A gente é da espécie humana, a gente não vai sair devorando nada, a gente não é assim. A ideia que a gente tem... 'O animal que eu sou, sou uma coisa embrutecida'. Não é, é o contrário. Você se vê e olha o outro de outra maneira. A ideia que me vem é que tinham coisas que eram de todos e que eu levava para mim, como se tivesse que levar sozinho. Mas é de todos, esses dramas são de todos, não tem que levar nada...

Ele afirma que entender a evolução o fez perceber que o ser humano é um animal, o que não significaria dizer que se é um ser embrutecido e nem que se deixaria de lado características como projetar e articular um pensamento. Mais ainda, tal ideia lhe fez ver os outros humanos como semelhantes e que os medos que tinha (como da morte, indicado no trecho anterior) não eram exclusivos seus e, portanto, não seria preciso carregar este fardo ("não tem que levar nada").

De acordo com Numbers (2006), os fundamentalistas, que no início do século XX lançaram o movimento anti-evolucionista, argumentavam que a teoria darwiniana era responsável pela crise de valores da sociedade da época por tirar o lugar de prestígio do ser humano em relação aos outros animais, por dispensar a ação de um Deus criador e, consequentemente, desvalorizar os valores cristãos. P1 vai no sentido contrário dos argumentos dos fundamentalistas de outrora, encontrando identificação com outras pessoas, conforto e sentido na vida a partir de conhecimentos científicos e não religiosos.

Por fim, P1 ainda expressa uma definição de Deus alternativa à tradição judaico-cristã, à qual havia se remetido anteriormente: 
E até na questão da aceitação da religião, eu desenvolvi uma forma de ver isso como algo que tem sua contribuição. [...]digo 'vai com Deus', digo na boa, porque Deus para ele é uma coisa. Para mim, não deixou de existir. Existe, mas Deus representa uma série de sensações, de conforto, de segurança, de afeto, de aceitação, a coisa mais humana possível... Reconhecer o outro como igual.

Neste depoimento, o professor declara que acredita que a religião tem contribuições a oferecer às pessoas. Além disso, afirma que não deixou de acreditar em Deus, mas este não possuiria uma forma humana, nem seria um agente na natureza. Sob o nome de Deus, P1 reúne uma série de sentimentos positivos que um indivíduo pode ter em relação ao outro e a si mesmo (conforto, afeto, segurança e aceitação). Na última frase, ele diz que a ele religião pode fazer com que uma pessoa reconheça a outra como igual. Embora não tenhamos mais dados para nos aprofundar, vale destacar que esse reconhecimento do outro como igual foi algo determinante, em sua própria fala, para que abandonasse a crença religiosa e adotasse uma visão de mundo baseada nos conhecimentos científicos. Tal atitude pode sugerir que haja, em sua visão, uma sobreposição entre as áreas em que ciência e religião poderiam atuar.

Em resumo, P1 já esteve ligado a diferentes religiões, porém hoje as abandonou. Sua visão com relação à origem e evolução da vida na Terra é bastante próxima da científica, considerando a teoria neo-darwinista como verdade e o criacionismo como algo falso, ingênuo ou equivocado. Seu afastamento de crenças religiosas se deu em função de seus estudos em biologia na faculdade, os quais lhe fizeram ter mais contato com o que acredita ser a verdade e esta, por sua vez, lhe trouxe mais conforto. Como veremos nos próximos capítulos, sua visão sobre o relacionamento entre ciência e religião e, mais especificamente, entre evolução e criacionismo, provoca impactos em suas aulas, uma vez que, em uma delas, fez forte oposição e até mesmo ironizou as crenças religiosas de uma aluna.

\section{2}

Concepções de P7 sobre evolução e criacionismo: uma visão budista

O professor P7 se diferencia dos demais, uma vez que é budista, da denominação Soka Gakkai. Ainda que tenha passado pela Umbanda, Catolicismo, Igreja Messiânica e Pentecostalismo, demonstra mais identificação com o 
Budismo, para o qual, de acordo com o seu depoimento, a visão sobre a origem do universo e da vida é muito próxima da ciência. No entanto, ele também demonstra certa dificuldade em definir sua visão de evolução dos seres vivos. O mapa conceitual apresentado na Figura 4.2 sintetiza suas ideias.

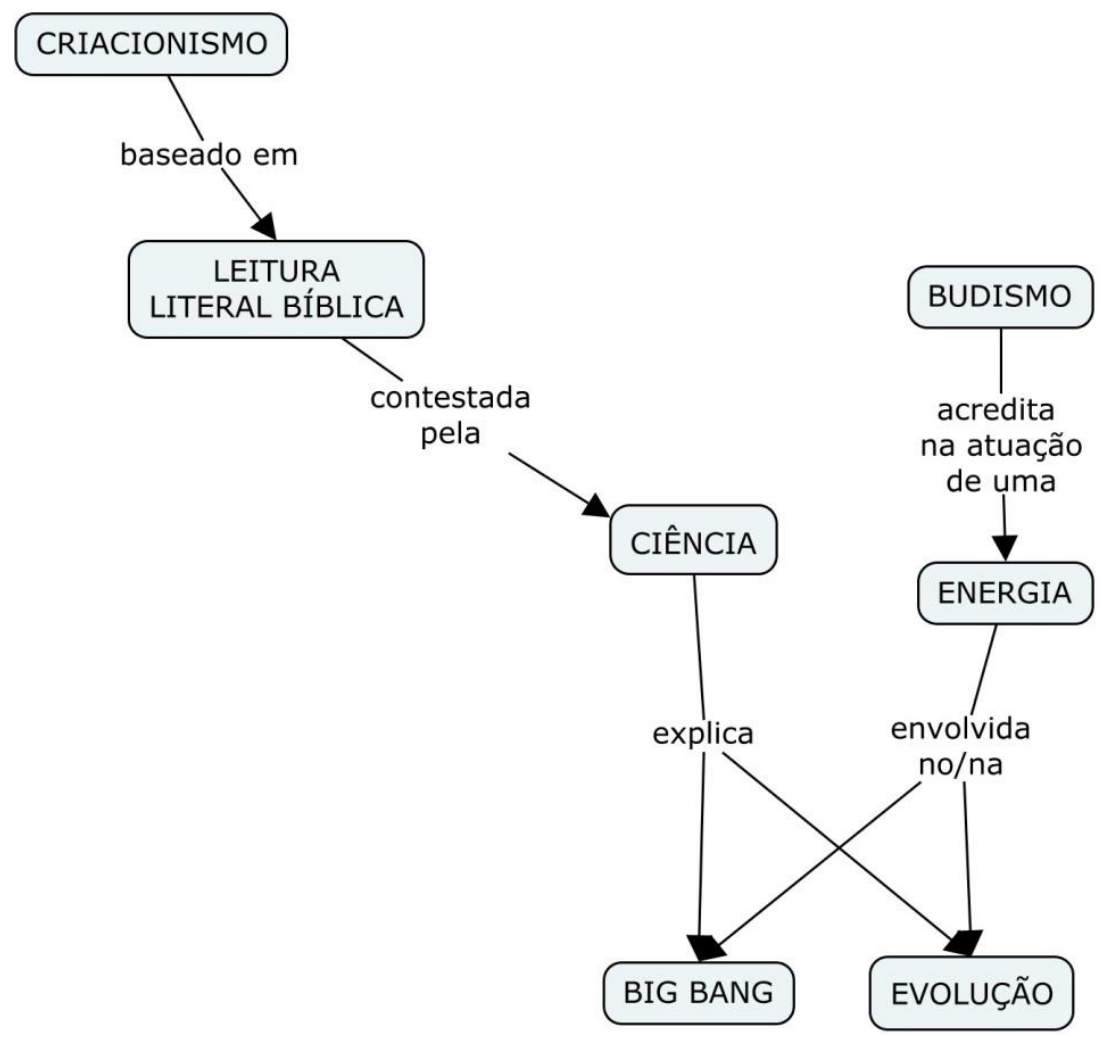

Figura 4.2: Concepções de P7 sobre evolução e criacionismo.

Assim como P1, P7 identifica o criacionismo com uma leitura literal do livro do Gênesis na Bíblia, com Deus atuando diretamente sobre a criação dos seres vivos e do universo - reforçado pelo seu gestual durante a entrevista, sugerindo manipulação. Da mesma forma que o professor anterior, questiona o fixismo, argumentando que o registro fóssil não lhe dá suporte, fazendo com que o relato bíblico, em sua opinião, seja incoerente.

\section{P: Quando a gente fala de criacionismo o que te vem mais forte?}

P7: A imagem de Deus fazendo assim [faz gesto com a mão], criando o mundo. Na verdade, vem o Gênesis. Os primeiros capítulos de Gênesis. [...] eu, na minha opinião, é tudo muito incoerente. Tem várias evidências, principalmente. [...] Deus criou uma girafa, desde sempre? E que bicho é esse aqui, que a gente viu como fóssil? [...] E a Arca de Noé? Todas as espécies do mundo estavam ali naquela arca? Só tinham aqueles bichos ali? Só na tua casa tem mais bicho que na arca de Noé. Inseto, rato... Essas coisas todas. Essas coisas assim que eu acho muito incoerente.

Essa visão de criacionismo não interfere sobre suas crenças religiosas, pois, como explica, o Budismo se preocupa mais com aspectos sobre o 
relacionamento entre as pessoas e as ações dos indivíduos durante suas vidas do que com as origens do universo e dos seres vivos.

\begin{abstract}
P: E qual é a explicação do Budismo para o universo? Tem alguma explicação?
P7: Tem... O Budismo, [...], praticamente todas [as denominações] são muito fiéis à ciência. [...] Essa questão do criacionismo é a ciência. Mas é isso aí mesmo, Big Bang, energia. A questão da energia, tem a parte mística. Mas a parte mística é a energia. Mas você não tem que se preocupar, cara, com isso. No Budismo, você não tem que se preocupar com isso. Você tem que se preocupar com a sua vida e o seu tempo de vida aqui, onde você está. Você vai ter sua vida aqui, procurando melhorar a sua vida e a vida dos outros, o ambiente em que você vive ou você vai querer ficar procurando respostas do que que surgiu tudo? Então, assim, a ciência descobriu mais alguma coisa? Legal. Tá aí no caminho.
\end{abstract}

Embora ele não forneça muitos detalhes, P7 explica que o Budismo não se opõe ao conhecimento científico sobre as questões acerca das origens do universo e da vida. Ele menciona, todavia, que para os budistas há uma esfera mística que envolve a relação de uma energia sobre os processos descritos pela ciência. Quando questionado para que desse mais detalhes especificamente sobre sua visão de criacionismo, ele demonstra dificuldade de definir as características do envolvimento dessa energia.

\begin{abstract}
P: Entendi. E como é que você definiria o criacionismo?
P7: É... Seria a criação do mundo em que vivemos através... [...]Através de uma energia mesmo. De uma força. De um ser, de um ser não. Vamos dizer assim, o surgimento do mundo através... É, se for pensar no criacionismo, a gente pensa logo no criacionismo do cristianismo,né? [...]Você me fez pensar agora numa coisa que eu não tinha percebido, numa outra forma de ver o criacionismo. Criação do mundo, mas através dessa energia. E aí, eu não acredito também no caos, sabe? Não sei. Não consigo definir fora disso, não. É a teoria do Big Bang, mas ao mesmo tempo é muito estranho você imaginar que todo o universo tava num... Mas falando de criacionismo... Não, você quer que eu defina o criacionismo, né?

P: Pode falar do jeito que você quiser.

P7: Falando de criacionismo eu vejo por essa ótica do que seria o mundo sendo formado por uma entidade, ou por um tipo de Deus, uma entidade que constrói aquele mundo ali segundo os seus moldes. Segundo o que ele quer. E não uma sucessão de eventos que vão... Justamente o meio vai selecionando aquilo dali. Eu acho que desde o começo foi isso. Mesmo a união de um átomo com o outro ali, foi uma circunstância de um estar próximo do outro... Condição de vida aqui no planeta...
\end{abstract}

É interessante notar que P7 não consegue definir precisamente como essa energia estaria envolvida no processo de surgimento do universo, chegando a dizer que nunca havia pensado sobre o assunto. Ele tenta dar uma definição ampla de criacionismo, que vá além da atuação de uma figura definida - como Deus na tradição judaico-cristã - mas não consegue. Além disso, diz que não consegue aceitar o caos - um dos elementos da doutrina budista - e demonstra resistência à teoria do Big Bang. Na segunda metade do trecho apresentado acima, ele tenta definir mais uma vez o criacionismo de uma forma ampla, remetendo a uma entidade ou Deus, e adiciona, ainda, que o meio foi "selecionando" aquilo que 
estava sendo formado, em uma referência ao processo de seleção natural. Embora tenha dito anteriormente que o interesse do budismo era diferente da ciência, esse trecho mostra que, em sua visão, de certa maneira, há o cruzamento dessas duas formas de conhecimento (representado na Figura 4.2 pelo cruzamento das setas). Assim, poderíamos dizer que sua visão sobre o relacionamento entre ciência e religião possui certa hibridização entre o que Barbour (2000) chama de independência - e Gould(1999), de Magistérios Não-Interferentes -, quando ocupam lugares plenamente distintos, e integração(BARBOUR, 2000), quando podem oferecer contribuições uma a outra e chegar a conclusões semelhantes.

Quando questionado porque ensina o criacionismo, P7 oferece uma resposta mais direta e contundente que o aproxima novamente de uma ideia de independência, e até mesmo de conflito (BARBOUR, 2000), entre ciência e religião.

P7: Eu não digo pra desbancar teorias de criacionismo nem nada não, mas eu acho que as pessoas têm que saber que a evolução é um fato. Tem que ser mostrado. Tem gente que, até hoje, não acredita que dinossauro existe.

Ao dizer que a evolução é um fato, há uma indicação de que esta estaria mais próxima da verdade do que o criacionismo. Cabe destacar, ainda, o uso que ele faz do conceito de teoria, para se referir a diferentes visões criacionistas. Ainda que não tenhamos mais dados para nos apoiarmos, nos parece que esse uso busca valorizar, em certa medida, as visões de mundo baseadas na criação do mundo por alguma entidade transcendental, sendo possível referir-se não só a formulações científicas como teorias. Se para P7 tal referência não aparenta ter grandes impactos em sua concepção sobre a evolução, para outros professores, como P2 e P5, esta situação se torna mais complexa, como será discutido mais à frente.

Em síntese, P7 rejeita o criacionismo bíblico e tende a aceitar o conhecimento científico como verdadeiro, embora tenha dificuldades de determinar as fronteiras entre os domínios da ciência e de sua religião, o budismo. Acredita que há uma energia envolvida no surgimento do universo, porém não sabe precisar como ela se relaciona com a evolução dos seres vivos. Mesmo que ele não separe ciência e religião tão claramente quanto $\mathrm{P} 1$, ele também não flexibiliza essas duas formas de conhecimento tanto quanto os outros professores que analisaremos a seguir. 


\section{3}

\section{Concepções e estratégias de P2 para conciliar a evolução e 0 criacionismo: nosso lugar no universo e o uso dúbio de "teoria"}

A professora católica não-praticante P2 mostra incertezas quanto à sua visão de mundo, porém tende a conseguir conciliar evolução e criacionismo. Ela argumenta criticando alguns elementos do pensamento científico e flexibilizando conceitos religiosos. Sua formulação final mistura conceitos de ambas epistemologias sendo difícil estabelecer fronteiras claras entre elas. Sua visão pode ser resumida no mapa conceitual da Figura 4.3.

Inicialmente, é interessante notar que, quando questionada se já havia tido algum conflito entre sua crença religiosa e seus estudos em biologia, P2 afirma veementemente que não. Todavia, em um momento posterior da entrevista, ao falar sobre o ensino de criacionismo e evolução, ela afirma que possui questionamentos sobre sua própria visão sobre o tema, indicando que, até certo ponto, ainda teria um conflito pessoal entre a visão científica e a religiosa.

P2: Não, nunca. Nem na época que eu era estudante de biologia, que tava no início da faculdade, que frequentava sempre a igreja, todo domingo, nunca, nunca tive. Que nem outras religiões que, se você acredita naquilo, então você tem que negar todo resto. [...] Eu posso acreditar, posso ter minha fé em Deus, mas não consigo dizer que aquele fóssil que está ali, aquelas provas todas, como vou negar aquilo tudo?

P2: É tão complexo isso que você tá me perguntando, porque eu me questiono também de muitas formas. Eu falo de origem da vida, eu tento explicar para o menino o que ocorreu na evolução, mas nem eu sei! Sabe, assim, até eu tenho dúvidas. Eu acredito também em Deus e fico dizendo para ele 'olha, foi lá a moleculazinha[risos] que juntou e formou a célula'. [...] Então, eu tenho vários questionamentos também com relação a isso.

No primeiro trecho, a professora afirma que nunca teve conflito, nem mesmo quando esteve mais próxima da sua religião, indo com frequência a missas e iniciando seus estudos superiores em biologia. Ela argumenta que, ao contrário de pessoas ligadas a outros credos, ela se mantinha flexível, rejeitando partes do discurso religioso sem que isso o invalidasse como um todo. Ao mesmo tempo reconhecia a validade de evidências científicas da evolução, como fósseis, por exemplo. Já no segundo trecho ela usa expressões que demonstram dúvida com relação à sua visão sobre a origem da vida ("tão complexo", "me questiono de muitas formas", "nem eu sei", "até eu tenho dúvidas", "tenho vários questionamentos"). Esse questionamento está articulado ao ensino de evolução e origem da vida, já que ela comenta que explica algo aos alunos, do qual ela não 
tem certeza. Essa declaração, juntamente com suas posturas observadas em sala de aula, levantam questionamentos para a relação entre as crenças pessoais e o ensino de evolução que abordaremos mais adiante.

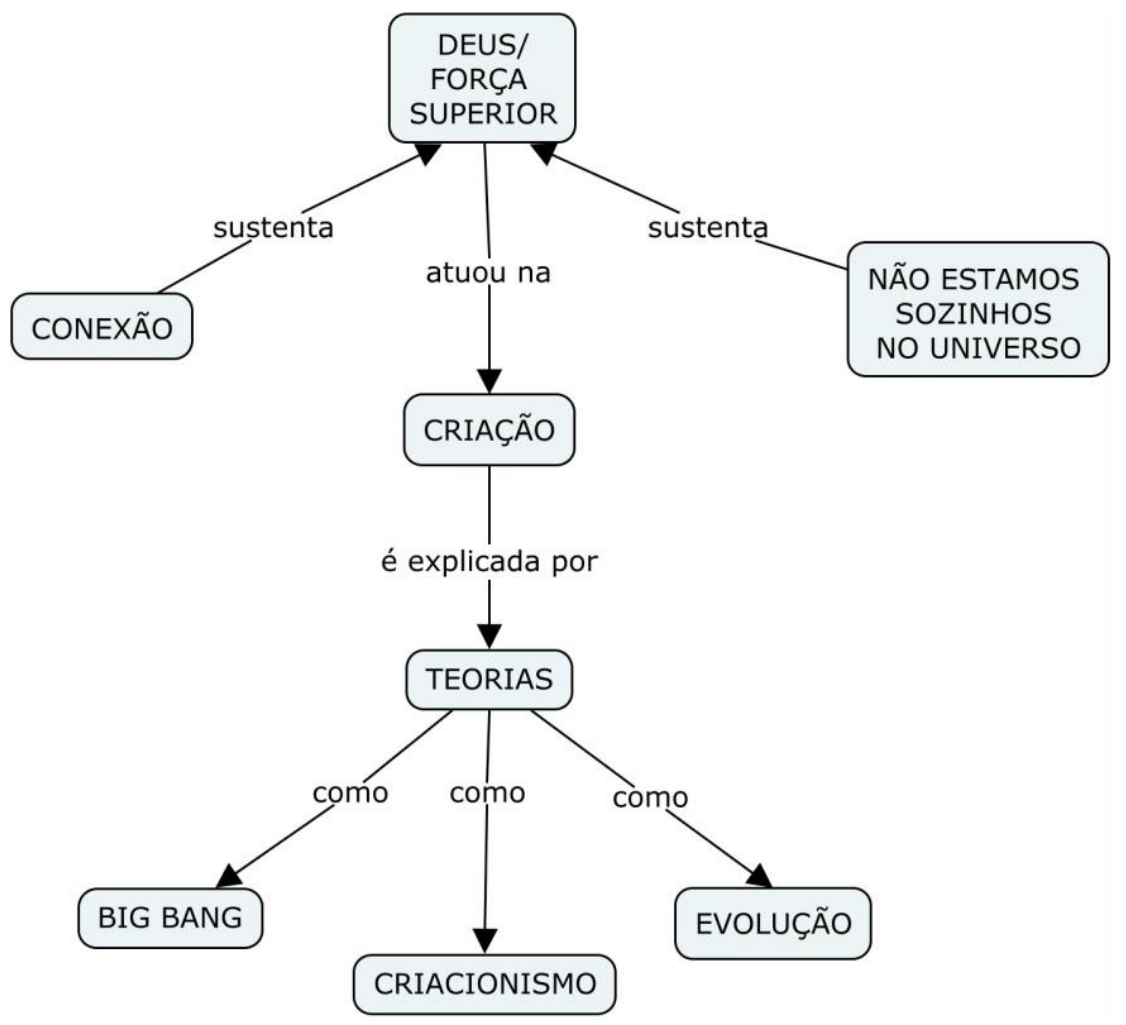

Figura 4.3: Estratégias de P2 para conciliar criacionismo e evolução.

Ao ser questionada se possuía alguma explicação pessoal para o criacionismo, P2 detalha as estratégias que utiliza para conciliar o pensamento científico e suas crenças religiosas. De uma maneira geral, essas estratégias passam pela flexibilização desses dois domínios. A primeira delas é expressa no seguinte trecho:

P2: Mas, assim, achar que nesse universo imenso só estamos nós aqui, e mais ninguém, eu acho que a gente é metido demais, isso eu não acredito. Eu acho que tem alguma coisa além. [...] O que eu acho, que teve uma criação, ela teve. Não sei se existe um deus. Eu só acho que nos conforta acreditar que tem alguma coisa maior do que a gente. [...] Eu acredito que tem uma força lá em cima, que tem alguma coisa. Eu me conecto e fico bem com isso.

É interessante notar que P2 articula a ideia de grande extensão do universo à ideia de que não estaríamos sozinhos nele. Ela, então, afirma que acredita em alguma entidade transcendente, não necessariamente um deus, que teria atuado na criação. Embora ela não diga que sinais poderiam ser interpretados como indicadores dessa criação ou dessa entidade, ela conclui dizendo que se conecta e 
se sente confortável com isso. Nesse trecho é possível perceber que ela usa conceitos que estariam, em princípio, mais próximos de uma perspectiva científica, como a extensão do universo, para sustentar uma afirmação religiosa, ou, ao menos, transcendental. Esse uso de uma experiência do cotidiano como fonte para pensar sua relação com o transcendente é definida por Peterson, Hasker et al.(2013)como um insight religioso. Embora eles sejam distintos de experiências religiosas, quando o indivíduo tem ou acredita ter tido um encontro com alguma realidade transcendente(PETERSON et al., 2013), também são tratados como importantes para que se alcance o objetivo último de libertação e salvação.

O segundo aspecto relaciona-se com a forma como P2 vê as teorias de origem da vida e do universo. Ela usa o termo "teoria" como sinônimo de uma explicação que pode ser facilmente desacreditada: "Essa parte é complicada, eu acho que são teorias mesmo, mas ninguém tava lá, ninguém pode provar absolutamente nada".

É possível perceber que a sua noção de teoria é acompanhada por uma visão de ciência que frisa a observação direta e a ideia de comprovação. Assim, se não há observação direta ("ninguém tava lâ"), não há provas ("ninguém pode provar absolutamente nada") e, portanto, essas teorias não apresentariam bases sólidas. Ainda que a origem da vida, do universo e a evolução dos seres vivos não possam ser diretamente observadas, não quer dizer que não haja evidências válidas sobre essas teorias. Como Scott (2009) afirma, a observação direta é uma ferramenta poderosa da ciência, mas não é a única. Além disso, a autora também defende que muitos cientistas evitam o termo "provas", já que este sugere certeza absoluta. Nesse sentido, a ciência buscaria encontrar verdades sem ser capaz, contudo, de produzir afirmações definitivas sobre o mundo natural.

Há ainda outro trecho em que a professora se refere mais especificamente ao criacionismo. O currículo mínimo estadual prevê que sejam ensinadas também explicações religiosas para a origem da vida ${ }^{43}$. Nesse sentido, P2 ensinou a versão literal e fixista do criacionismo bíblico em aulas que foram observadas nessa pesquisa. Ao ser questionada, durante a entrevista, por que ensina o criacionismo,

\footnotetext{
${ }^{43}$ Como pode ser visto no Anexo 4: "Reconhecer a existência de diferentes explicações para a origem do universo, da Terra e da vida, bem como relacioná-las a concepções religiosas, mitológicas e científicas de épocas distintas" (SEEDUC, 2012, p.11).
} 
ela respondeu: "Primeiro porque é uma teoria, eu não posso negar essa teoria. É a mais antiga, é a que nos acompanha".

Se no trecho anterior, o uso do termo teoria era o que justificaria a evolução não ser uma verdade absoluta e o que justificaria também uma possível rejeição para explicações sobre a origem do universo e origem e evolução da vida, neste trecho o termo teoria sustenta a validade do criacionismo. Em outras palavras, como o criacionismo também é uma teoria, deve ser ensinado. Ainda que ela não afirme explicitamente que o criacionismo seja uma teoria científica, seu uso indiscriminado para abranger concepções científicas e religiosas não contribui para o entendimento da natureza do pensamento científico e do pensamento religioso - argumento a que voltaremos em outro momento. Para além das implicações didáticas, é possível perceber que tal concepção sobre teoria permite uma flexibilização da ideia que a docente tem de ciência e de religião, favorecendo uma explicação que mescle elementos dessas duas epistemologias.

Em resumo, P2 adota uma visão que utiliza conceitos científicos e religiosos, mas de forma flexível para alcançar uma formulação que lhe seja minimamente coerente. Essa construção, contudo, apresenta certas limitações para ela mesma, que a fazem ter questionamentos sobre a origem da vida e do universo. Além disso, sua visão se baseia em uma concepção dúbia de teoria, ora como uma explicação sem forte fundamentação de evidências, ora como algo que confere validade a um determinado pensamento, e, ainda, em uma visão de ciência calcada exclusivamente na observação direta e na formulação de fatos comprovados.

\section{4}

\section{Concepções e estratégias de P3: flexibilização de conceitos científicos e religiosos}

A professora P3 é católica, foi catequista durante muitos anos, porém, no momento, afirma que não está tendo o tempo suficiente para se dedicar à igreja, ainda que sinta falta disso. Tal qual P2, ela também formula uma ideia própria da origem e da evolução da vida e do universo que se baseia na flexibilização de conceitos científicos e religiosos. Sua visão pode ser resumida no mapa conceitual da Figura 4.4. 


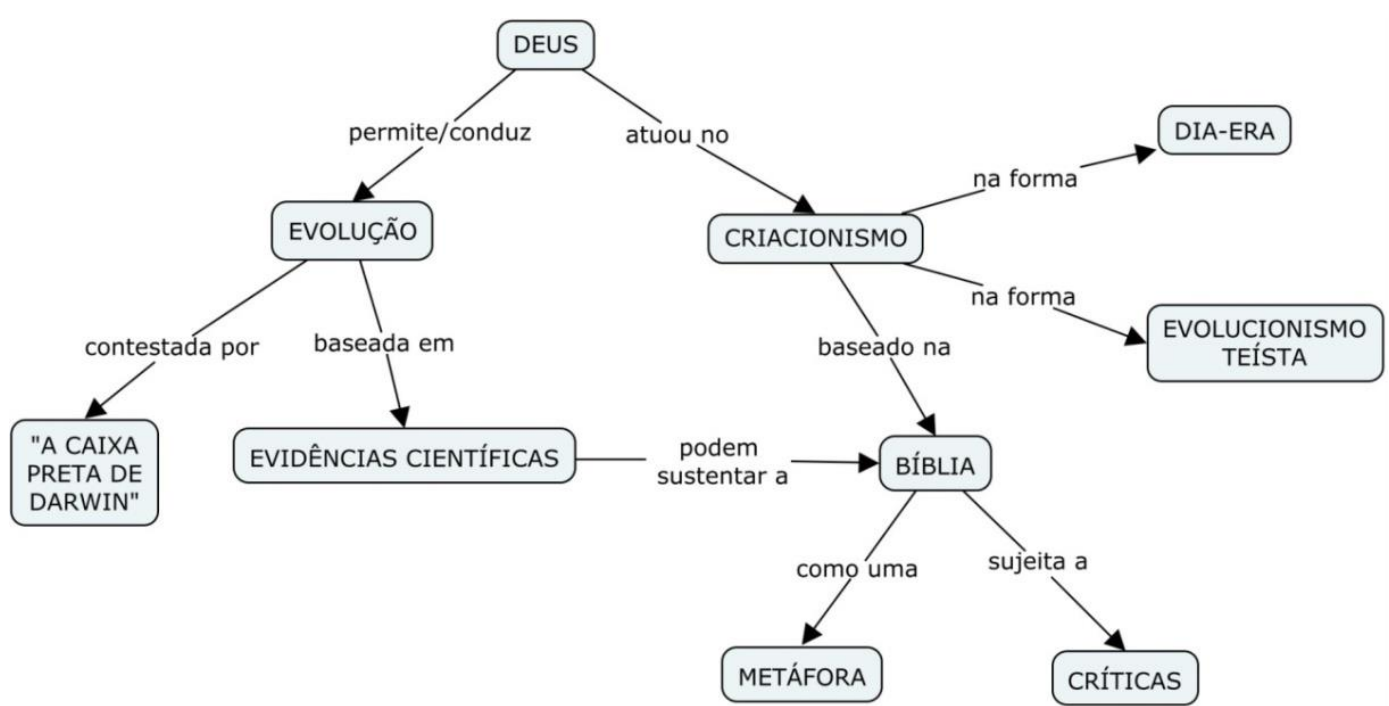

Figura 4.4: Estratégias de P3 para conciliar criacionismo e evolução.

Ao contrário de $\mathrm{P} 2$, essa professora parece estar mais confortável com a sua versão para a origem da vida e do universo, ainda que use algumas expressões de incerteza ao longo da entrevista. Ela afirma que sempre procurou conciliar sua crença religiosa com seus estudos em biologia:

P3: Nunca a minha formação [acadêmica]bateu de frente com a minha religião. Acabou uma coisa completando a outra, ajudando, de uma certa maneira.[...]. Nunca acabou me atrapalhando. Eu sempre procurei o meu entendimento. Uma coisa vai ajudando a outra. Vai melhorando.

Em sua fala, é possível perceber que ela distingue os dois tipos de conhecimento, religioso e científico, e que busca utilizar um para ajudar a entender o outro. Ou seja, quando encontra uma limitação em um- no seu ponto de vista - , recorre ao outro. Isto se reflete nos diferentes argumentos que viabiliza para construir sua estratégia de conciliar criacionismo e evolução:

P3: Mas, eu vejo nisso, eu acredito, sim, que há essa força divina [...] "Ah, mas é a sopa orgânica, é o Big Bang, essa energia no espaço pra ter antes". O que tinha antes disso? Só Deus pra dar esse 'start', esse início, porque o resto foi acontecendo que permitiu isso. Tanto que eu acho que Ele permitiu que a gente estude, descubra essas coisas, já que eu acredito em Deus, né? Então, eu acho que tem essa participação Dele, mas que não é nessa escala que a gente vai ler na Bíblia e vai ter ali certinho... Entendeu? Misturando uma coisinha na outra... Que esse antes, quem preparou, quem permitiu...

Nesse trecho, ela reforça sua crença em Deus e demonstra aceitar teorias científicas sobre a origem da vida (a "sopa orgânica", se referindo aos trabalhos de Oparin) e do universo (Big Bang). Contudo, ela faz questionamentos sobre o que teria existido antes dos fenômenos descritos por essas teorias. Dado que ela não encontra essa resposta nos conhecimentos científicos, ela atribui a causa desses processos a Deus. Além disso, ela ainda explica que Deus permitiu ao ser 
humano estudar esses acontecimentos, porém não através de uma leitura literal da Bíblia. Nesse sentido, ela levanta críticas aos pensamentos científico e religioso, apontando limitações em ambos e buscando complementá-los entre si. Tal ideia é reafirmada em outro momento da entrevista, quando questionada se possuía uma concepção pessoal do criacionismo.

P3: A criação divina teria sido dessa forma. Essa força maior orquestrando a formação... Desde lá das primeiras células, dos primeiros organismos, dos primeiros seres... Desde aquele marzinho... Até na criação quando você lê na Bíblia que fala... Antes tinha o mar, tinha muitas tempestades, aí liga um pouco a essa criação e aí você vai pensar nas hipóteses lá que você vai estudar na formação desses mares, das descargas elétricas, assim... Deus estaria orquestrando isso tudo pra formar, não que ele vai formar um ser de cada espécie, de cada sexo, não... Não desse jeito! [...] A minha concepção de criacionismo seria essa... Já envolvendo essa questão da evolução... Que ele permitiu, que ele permite que essa evolução ocorre.

Neste trecho ela volta a se referir a Deus como a causa do surgimento dos seres vivos e do universo e exemplifica como determinadas passagens da Bíblia encontram suporte em evidências e teorias científicas (as hipóteses científicas de origem da vida que afirmam que descargas elétricas nos mares primitivos poderiam ter sido importantes para a formação de compostos orgânicos e as afirmações do livro do Gênesis de que a Deus teria primeiro criado os mares, depois a terra e, posteriormente, os seres vivos). Ela finaliza dizendo que Deus teria atuado não só na criação, mas também na evolução dos seres vivos ou, ao menos, a teria permitido.

É interessante notar que no primeiro trecho P3 afirma que Deus teria "permitido" a origem da vida e no segundo trecho ela usa o termo "orquestrar". Se, por um lado, o primeiro pode sugerir que Deus teria consciência do processo, mas não teria, necessariamente, um papel ativo de interferência, a segunda expressão sugere mais que uma permissão, mas sim uma ação organizadora ( "orquestrar"). Não fica claro se para a professora há essa distinção, dado que ao final do primeiro trecho aqui exposto ela diz "Que esse antes, quem preparou, quem permitiu...", indicando que, possivelmente, haveria diferença entre as noções de preparar e permitir, pois parecem ser atuações diferentes: permitir, preparar e orquestrar. Independentemente dessas definições, os termos apontam para o fato de que Deus seria a causa da origem e evolução da vida e do universo e que os processos naturais aí envolvidos seriam apenas consequência, em um argumento que Evans, Legare e Rosengren (2011) chamam de cadeia causal 


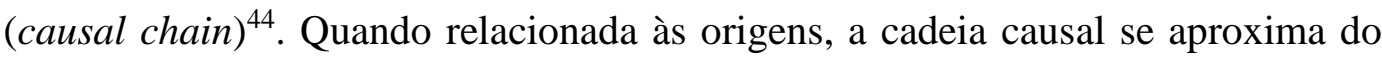
evolucionismo teísta, que de acordo com Scott (2009), afirma que Deus pode ter realizado a criação através de processos naturais como a evolução.

Sua concepção de criacionismo, porém, apresenta outros elementos que a fazem ler a Bíblia de uma maneira metafórica e não literal.

P3: Eu penso no criacionismo, aí eu entro naquela história do tempo, da escala temporal... Que Deus possa ter criado os seres vivos, mas não dessa maneira que a gente vê... Tão rápida, tão pronta... [...] Na Bíblia está lá sete dias, mas pra gente, na nossa escala, se a gente fosse colocar na nossa escala, não seria sete dias... Seriam muitos e muitos milhões de anos nessa escala aí de sete dias.

Nesse trecho ela faz uma crítica a uma interpretação estritamente literal do Gênesis, referindo-se a ela como "tão rápida, tão pronta". Ela se aprofunda dizendo que os sete dias indicados na Bíblia seriam, na verdade, intervalos de milhões de anos. Essa estratégia a permite conciliar teorias científicas sobre a idade da Terra e a evolução com suas crenças religiosas em um Deus atuante (preparador e orquestrador) no processo de surgimento do universo e dos seres vivos. Tal interpretação da Bíblia é identificada como Criacionismo de Dia-Era, Day-Age Creationism(NUMBERS, 2006), e, de acordo com Scott (2009), ainda que seja possível traçar, grosso modo, um paralelo entre a evolução e o criacionismo por esta via, há incongruências importantes que são ignoradas, tais como as plantas com flores sendo criadas antes de todos os animais e pássaros surgindo antes de animais terrestres, afirmações que não encontram suporte no registro fóssil.

Vale a pena destacar que a docente também levanta críticas à teoria evolutiva neodarwinista. Ela se baseia em leituras que já realizou e que ajudariam a reforçar sua crença no criacionismo.

P3: Eu já li aquele livro "A caixa preta de Darwin”. Aí você vai ver lá, dentro de uma célula, uma coisa tão complexa que algo a mais... Ninguém consegue explicar aquilo. Então, talvez, Deus quem possa explicar aquilo e permitiu que fosse daquele jeito... Porque é tudo tão perfeito, tão sincronizado, que você... Cientificamente, a gente não tem resposta.

Ela se refere ao livro "A Caixa Preta de Darwin" de autoria de Michael Behe (1997), não só pelo título da obra, mas também pela ideia de "complexidade irredutivel" elaborada por este autor. Ela afirma que as células dos seres vivos são

\footnotetext{
${ }^{44}$ Cabe ressaltar que São Tomás de Aquino usou esse argumento no século XIII como uma das provas para a existência de Deus. Tomás de Aquino defendia que não poderia haver efeito sem causa. Assim, deveria haver uma causa primeira, que não teria sido causada por ninguém, pois, do contrário, seriam necessárias cadeias de causas infinitas para justificar cada efeito.
} 
estruturas muito complexas e sincronizadas que é possível que Deus tenha permitido que elas funcionassem assim. P3 afirma, ainda, que cientificamente não há resposta. Ainda que o trabalho de Behe (1997) tenha sido amplamente criticado por outros pesquisadores (PADIAN; MATZKE, 2009; SCOTT, 2009), é interessante notar a sua importância para a construção do pensamento de P3. Para a professora, o livro forneceria evidências científicas para questionar a teoria evolutiva e reconhecer a possível existência de um planejador, orquestrador. Se os argumentos apresentados anteriormente estavam baseados em sua fé e na flexibilização do discurso religioso para acomodar-se a determinados conceitos científicos, aqui o próprio discurso científico estaria sendo usado para criticar a evolução.

É interessante notar que P3 dá outros exemplos de passagens da Bíblia para as quais procura suporte de evidências científicas:

P3: Eu lembro que a gente teve uma aula lá de sagrada escritura e quando falou lá da questão de Moisés que abriu o mar vermelho. Que dentro da própria igreja já tem estudos que dizem que é um fenômeno que pode acontecer... Não abrir daquele jeito, com aqueles paredões de água como vem escrito na Bíblia, mas que aquilo possa ser possível acontecer... Como a questão lá de que Samuel orou e sol parou, aí tem a questão do eclipse, né?Que pra esconder o sol... Parou... Então, assim, eu acabo até dentro da própria biologia achando umas respostas para alguns fenômenos que tenham acontecido.

Ela cita diretamente a abertura do Mar Vermelho por Moisés e que Samuel ${ }^{45}$ teria orado para que o Sol parasse. É interessante notar que ela afirma que estudou sobre possíveis explicações científicas para estes relatos bíblicos dentro da própria igreja, em uma aula sobre sagrada escritura, parte do curso Luz e Vida, que cursou. Embora P3 não entre em detalhes de como esses processos poderiam ter ocorrido, ela explica que não acredita em um relato literal do texto sagrado, como pode se perceber quando menciona "Não abrir daquele jeito, com aqueles paredões de água como vem escrito na Bíblia" ou, ainda, quando introduz a possibilidade do eclipse para explicar a "parada" do sol. Por fim, ela sintetiza suas próprias ideias dizendo que encontra na própria biologia resposta para fenômenos semelhantes a esses.

Ainda com relação à leitura da Bíblia, P3 reconhece que o livro sagrado dos cristãos é passível de críticas e deve ser lido de forma metafórica, ainda que possua validade também como um relato histórico de uma época.

P3: Meu entendimento é que a Bíblia foi escrita por homens, a gente acredita que é uma inspiração divina, mas ela foi escrita por homens, então... Tem toda a questão da época

\footnotetext{
${ }^{45}$ De acordo com a Bíblia(Js, 10, 12-14), teria sido Josué e não Samuel.
} 
que foi escrita, da sociedade, do pensamento daquela época... Como que a questão da mulher na visão da Bíblia... Como era a sociedade naquela época? A gente tem que levar em conta essa consideração. Você pode ler a Bíblia como um livro histórico, mas tem a parte histórica que confirma lá que bate direitinho, mas tem também essa parte que você tem que pensar que muita coisa ali tem uma linguagem figurada, um entendimento num período que foi escrito das pessoas daquele momento poderia entender.

Neste trecho da entrevista, ela afirma que a Bíblia pode ser criticada, já que, apesar de ter inspiração divina, foi escrita por humanos. Além disso, a sociedade da época era distinta da nossa (ela cita, como exemplo, a forma como as mulheres eram vistas). Em seguida, ela apresenta como contraponto o argumento de que o texto bíblico pode ser visto como um relato histórico. Ela conclui dizendo que há muitos elementos da Bíblia que devem ser lidos de forma figurada, tendo em vista que teriam sido assim escritos para que pudesse ser entendido pelas pessoas daquela época.

Em síntese, é interessante observar que a visão de P3 está baseada na flexibilização dos conhecimentos científico e religioso. Ela aceita que os seres vivos se transformam ao longo do tempo, porém acredita que a ciência não consegue explicar suficientemente essas mudanças e, ainda, que é Deus a causa do processo evolutivo, bem como seria ele que o conduz e o organiza. Por outro lado, levanta críticas à Bíblia, a qual não lê de forma literal e procurar fornecer explicações científicas para determinadas passagens bíblicas.

\section{5}

\section{Concepções e estratégias de P4: cruzamento de ciência, cristianismo e espiritismo}

A professora P4 declarou em sua ficha de identificação (Apêndice 7) que não tinha religião e que só acreditava em Deus e em Jesus. Ao longo de sua entrevista, ela disse que já tinha sido católica e evangélica, mas que atualmente estava se aproximando do espiritismo porque, recentemente, tinha visto vultos e sentido a presença de pessoas já falecidas. Assim, embora não esteja filiada a nenhuma denominação religiosa específica, elementos do pensamento desses diferentes grupos religiosos atravessam suas ideias de Deus e a origem e evolução dos seres vivos. Sua visão pode ser resumida no mapa conceitual da Figura 3. 


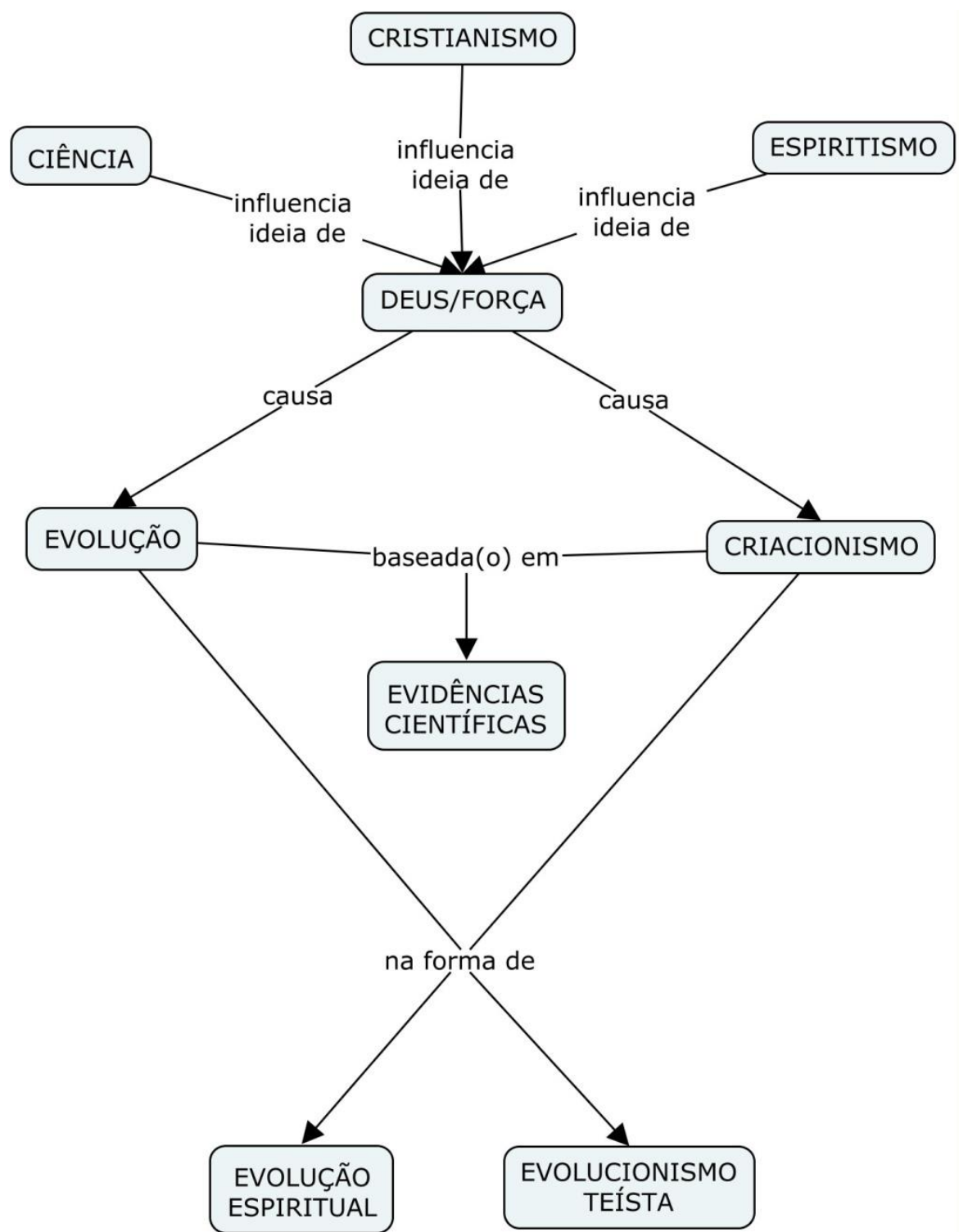

Figura 4.5: Estratégias de P4 para conciliar criacionismo e evolução.

É interessante notar que P4 afirma que nunca sentiu nenhum tipo de conflito interno entre suas crenças pessoais e seus estudos em biologia. No entanto, ao longo da entrevista, ela dá sinais de que ora se aproxima mais do pensamento religioso, ora do pensamento científico.

P4: Ora eu falo como bióloga, ora falo como cristã. Mas, o meu lado cristão é muito forte e mesmo como bióloga, eu percebo que o ser humano tem uma evolução muito maior do que um macaco, embora o macaco saiba que tenha que enfiar... [...] Esqueci o nome de uma planta... Que ele enfia pra tirar a verminose, já viu? [...] Então, ele tem isso, mas isso aí... Quem ensina ele isso? É o instinto, é o DNA. Mas quem comanda esse DNA? Moléculas. Mas quem comanda essas moléculas? O homem está muito acima disso. O macaco não tem espírito, tem? Você sente alguma coisa de espírito no macaco? Aí já é meu lado religioso. Tem algo, mas eu não sei... O ser humano tem uma evolução muito maior, eu não consigo deixar de ser cristã. Não tem como tirar... Não posso responder só como bióloga, não tem como, se não, não seria eu. 
Neste trecho, P4 se remete a um documentário que mostrava macacos utilizando uma planta para retirar parasitas de seu trato gastrointestinal. Através deste exemplo, ela se questiona qual a causa desse comportamento, partindo de ideias científicas como DNA e moléculas, mas chegando a uma formulação mais religiosa, que envolveria a impossibilidade de os macacos terem espírito. É importante notar que ao afirmar que o ser humano "está muito acima disso" disso se referindo ao controle de suas ações ser realizado pelo instinto, DNA e moléculas - e, logo em seguida, se questionar se os macacos possuem espírito, deixa subentendido que possuir ou não espírito é um critério importante para dizer se um ser vivo é mais evoluído do que outro. Essa hierarquia evolutiva é reconhecida por ela como algo religioso, quando ela reafirma, ao final, que o ser humano possui uma evolução maior e não pode responder apenas como bióloga, pois isso seria ignorar uma parte importante de sua identidade - "se não, não seria eu”.

É possível perceber uma maneira dúbia de relacionar os conhecimentos científico e religioso. Por um lado, ela os sintetiza e lhes atribui novos significados, como por exemplo, na ideia de "evolução espiritual", uma vez que o termo evolução possui um sentido diferente do científico, quando ela se refere ao ser humano ser mais evoluído do que o macaco. Por outro, a professora acredita que há uma cadeia causal (EVANS; LEGARE; ROSENGREN, 2011) entre elementos científicos e religiosos, quando sugere que comportamentos seriam controlados, em sequência, por instintos, DNA e moléculas e estas, por sua vez, possivelmente por espíritos. Foram esses diferentes tipos de cruzamento dos pensamentos religioso e científico que procuramos representar no mapa conceitual através das setas que se cruzam ao "saírem" de "evolução" e "criacionismo" e chegarem a "evolução espiritual" e "evolução teísta".

A ideia de Deus e de suas crenças religiosas como a causa última de processos naturais, é reforçada em outros momentos da entrevista:

P4: Deus tá aqui[faz um gesto levantando a mão]. O que é importante é que Ele está muito acima, e a gente está aqui abaixo [abaixa a mão] e está tudo num processo evolutivo. Eu penso que Deus está antes. A biologia está aqui[repete o gesto de abaixar a mão], mas a biologia é uma consequência, Ele é a causa.

P4: Tudo é consequência. Porque eu não tenho dificuldade de relacionar biologia com o Criador? Porque tudo é consequência do Criador. Eu não encaro a biologia como causa. Existem pequenas causas. Causa-efeito, mas a biologia, a vida, o ser é consequência. Eu acredito que Ele é a causa. [...] Mas eu acredito que essa origem é a força de tudo. 
A professora se refere diretamente a Deus como a causa e o processo evolutivo, a biologia e os seres vivos, como consequência. Tal qual já havíamos discutido com relação a P2, essa afirmação de P4 se aproxima do evolucionismo teísta (SCOTT, 2009). Ao adotar essa visão, ela não coloca em risco sua fé religiosa, mas consegue aceitar alguns conceitos e pressupostos da teoria evolutiva, o que seria difícil se adotasse uma leitura literal da Bíblia.

Vale a pena destacar que P4 se apoia em evidências científicas para sustentar tanto sua visão científica, quanto sua visão religiosa:

P4: Essa coisa de vulgarizar muito o homem como... 'Ah, o homem veio do macaco...' [...] E não é bem assim. Existe uma filogenia. Nós somos aparentados. Genuinamente aparentados, como irmãos, mas nós também somos aparentados da barata, do rato e tudo mais porque todos nós temos um DNA e tudo é formado por um único Deus.

Neste trecho, ela critica a afirmação bastante presente no senso comum de que "o homem veio do macaco", baseada em argumentos científicos de que há relações filogenéticas não só entre os humanos e outros primatas, mas também com outros seres vivos, evidenciadas pelas semelhanças no código genético. Entretanto, ela conecta tal justificativa também à ação de Deus. Nesse sentido, em sua visão, as evidências evolutivas poderiam também ser consideradas indícios da criação divina.

É importante ressaltar que há outro fator que a motiva a adotar um posicionamento que une elementos religiosos e científicos, a rejeição de "extremos".

P: Quando a gente fala em criacionismo, o que te vem mais forte à cabeça?

P4: Quer a real? Baboseira. Estou dando a real. Você quer que eu fale a verdade ou o politicamente correto?

P: Porque você falou baboseira?

P4: Eu acho que tanto de um lado quanto do outro, embora eu seja cristã, embora eu seja bióloga... Essas duas coisas vivem ao mesmo tempo na minha cabeça, eu não gosto dos excessos. Eu não gosto de que... 'Adão e Eva perderam o paraíso'. De alguma maneira, o homem perdeu o paraíso. Não sei se perdeu ou se ainda vai conquistar, é uma questão de evolução... [...]Eu acho baboseira de um lado e acho baboseira do outro... Aquele outro lado... 'Ah, não, Deus não existe... 'É a ciência...' 'O homem veio daqui e vai evoluir dali...' Eu não gosto desses extremos... Esses dois extremos eu acho baboseira, desculpa a expressão...

Há a rejeição de uma posição religiosa que faz uma leitura literal da Bíblia, que defenderia que Adão e Eva perderam o paraíso, por exemplo. Paralelamente, ela também rejeita uma visão estritamente científica de que a evolução ocorreria sem a interferência de nenhum tipo de ação divina e de que Deus não existiria. Tal postura faz com que P4 se incline a flexibilizar o pensamento científico e o 
religioso para formar sua própria concepção sobre a origem e evolução dos seres vivos. Isto se reflete igualmente na sua ideia de Deus.

Pra mim existe um Deus, eu não sei se ele tem forma humana, se não tem forma nenhuma, se ele é um aglomerado de moléculas... Eu não tenho nem capacidade pra definir isso, [...], eu me sinto totalmente incapaz, mas eu sei que essa força, que eu chamo Deus pra facilitar, tudo vem dela... Eu não sei se ela criou ou se sai dela mesmo, como se fosse uma fonte eterna de saída e uma fonte eterna de criações... Como se tudo fosse criado ao mesmo tempo por Ele e ao mesmo tempo fosse Ele mesmo.

Neste trecho podemos ver que ela associa elementos do cristianismo, da ciência e do espiritismo quando faz referência a Deus. Em seguida, diz que não sabe se Deus teria algum tipo de forma humana ou forma precisa ou se seria, ainda, um aglomerado de moléculas - um conceito científico. Logo após, ela diz que não tem capacidade para definir a forma de Deus, ao qual chega se referir como uma força que cria e é parte da criação ao mesmo tempo. Tal pensamento é influenciado pelo espiritismo de Allan Kardec, que em seu livro $A$ Gênese(KARDEC, 2013)afirma que Deus é imaterial, mas não cabe ao ser humano investigar a sua natureza. Além disso, Kardec (2013) também afirma que Deus é a causa primeira do universo e de toda a existência - argumento que P4 também expressa, como analisado anteriormente - e que Ele também faz parte de sua própria criação. Assim, é interessante notar que diferentes epistemologias com as quais teve contato ao longo de sua vida - cristianismo, espiritismo e ciência não se excluem, pelo contrário, são somadas para formular uma concepção pessoal, distinta das anteriores.

Em resumo, P4 apresenta uma concepção sobre a origem e evolução dos seres vivos que mescla elementos dos conhecimentos religiosos e científico. Ela não se identifica nem com a leitura literal da Bíblia, nem com uma visão estritamente evolucionista, preferindo adotar uma visão de que a evolução ocorre, mas é causada por Deus e envolve uma dimensão espiritual. Sua ideia de Deus sofre influências de conceitos científicos, judaico-cristãos e espíritas, mas a professora ainda demonstra algumas incertezas. 


\section{6 \\ Concepções e estratégias de P5: críticas e flexibilizações aos conhecimentos científico e religioso}

O professor P5 é católico, já foi catequista, coordenador da Juventude Franciscana e membro de banda na paróquia que frequentava. Atualmente, todavia, diz que não consegue participar mais tanto quanto gostaria, principalmente em função de seu trabalho e de seus filhos. Quando questionado se já havia tido alguma dificuldade para conciliar seus estudos em biologia com sua crença religiosa, ele diz que não.

P5: Inclusive até uma vez na faculdade, a professora de evolução ela criou um debate realmente sobre evolução e eu sempre tive a cabeça mais de escutar e analisar... Nunca fui aquilo de... "Não, o que eu sei é isso aqui e eu não quero saber de mais nada". Não. Então, na faculdade, apesar da minha veia religiosa, nunca tive esse problema.

Em sua fala, ele afirma que nunca teve dificuldade de lidar com os conhecimentos científico e religioso. P5 exemplifica, através de uma situação que viveu durante sua graduação, em que uma professora promoveu um debate sobre a evolução e ele teria assumido uma postura de ouvir diferentes pontos de vista e de analisá-los, evitando manter-se fechado a opiniões diferentes da sua. Ao longo da entrevista, como veremos a seguir, ele demonstra coerência com essa declaração. O mapa conceitual da Figura 4.6 sintetiza os principais elementos de sua concepção, como discutiremos a seguir. 


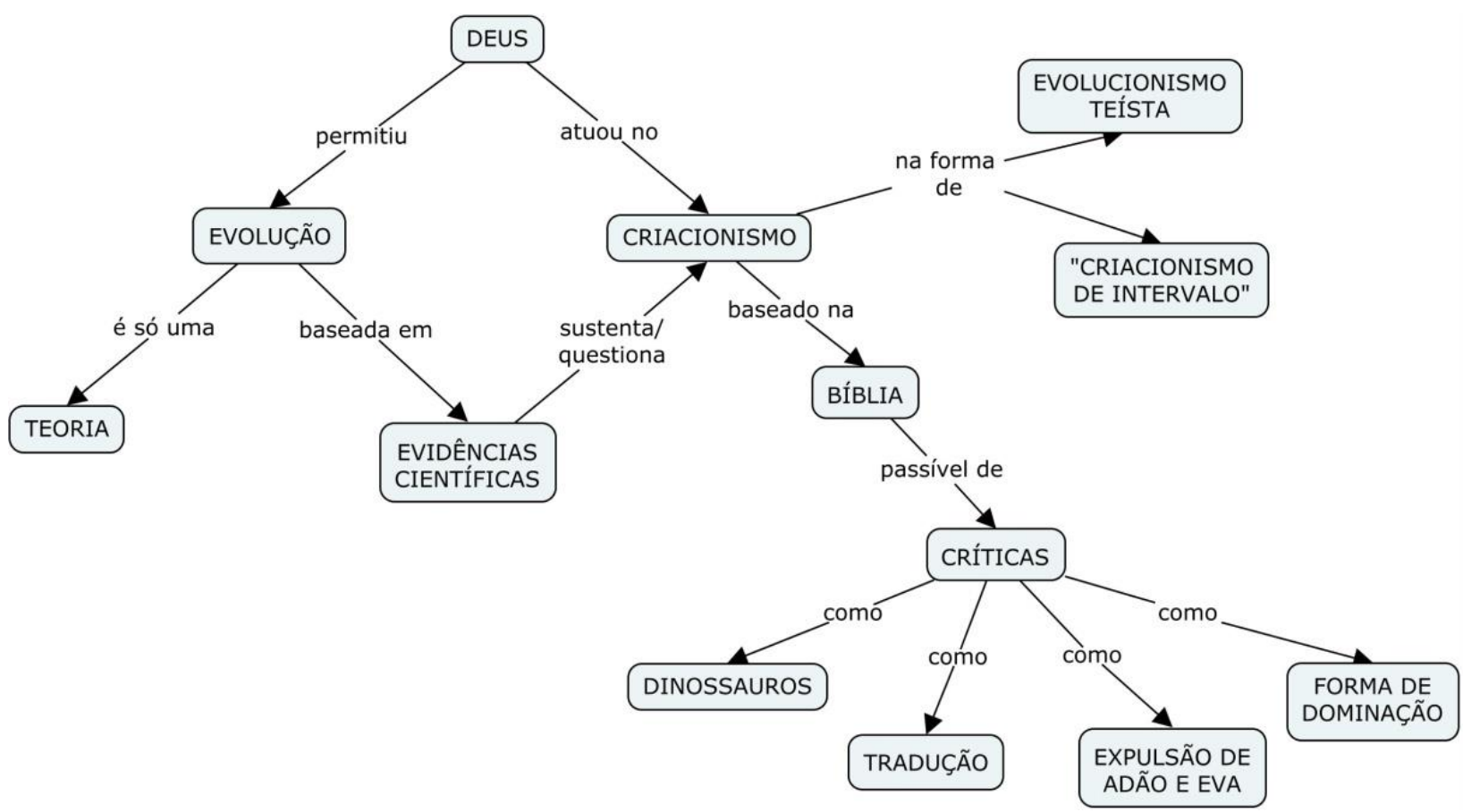

Figura 4.6: Estratégias de P5 para conciliar criacionismo e evolução.

Um primeiro elemento importante para a construção do pensamento de P5 é ideia de que Deus permitiu a evolução e a origem da vida:

P5: Por que é que o surgimento da evolução química não possa ter sido uma vontade de Deus? De repente possa ter sido uma vontade Dele... Até a evolução química... Não que Ele tenha feito... "Ah, junta isso aqui". Não, mas proporcionou isso...

O professor levanta a possibilidade de que a evolução química - nome pelo qual a principal teoria científica de origem da vida era chamada nos materiais didáticos utilizados em sala de aula - tenha ocorrido porque Deus assim permitiu. Ele acrescenta que a atuação divina não teria sido de forma direta, quando diz que Deus não teria dado uma ordem para que se juntassem determinados componentes para a formação da vida. Sua visão parece indicar um papel mais passivo de Deus, no sentido de fornecer as condições necessárias ao surgimento da vida pelos mecanismos que a teoria científica aponta, sem, contudo, controlar todos os fenômenos ali envolvidos. Assim como P3 e P4, a concepção de P5 se aproxima do evolucionismo teísta (SCOTT, 2009). No entanto, é interessante analisar que P5 elabora uma maneira própria de unir as teorias científicas e o relato bíblico. Durante a entrevista ele diz que consegue harmonizar ciência e religião.

P5: Então, uma brecha que eu encontrei pensando, foi o quê? Que a hipótese da extinção dos dinossauros foi do meteoro. Que o meteoro caiu na Terra e que o meteoro caiu e matou grande parte dos dinossauros, não matou todos. Criou uma nuvem que tampou a luz do sol. Essa nuvem tampou a luz do sol e os dinossauros foram morrendo, então como tampou a luz do sol, a Terra ficou escura, as trevas e na criação bíblica, uma das 
primeiras coisas que está escrito lá é que a Terra era disforme e estava nas trevas, sem luz do sol. Então, foi uma maneira que eu tentei encontrar, uma ligação que de repente os dinossauros foram criados e com a extinção dos dinossauros, começou-se então a criação do que a gente tem do ser humano, a criação bíblica. [...] Pode ser que tenha ocorrido a evolução química, aí depois surgiram os animais, surgiram os dinossauros, $e$ depois veio a criação bíblia.

É interessante notar que P5 separa temporalmente a origem da vida e o relato bíblico do Gênesis. Ele afirma que poderia ser possível que a evolução química tenha ocorrido em um dado momento e, posteriormente, terem surgido os animais, dentre eles os dinossauros. Somente em uma terceira etapa teria ocorrido a criação conforme relatada na Bíblia. Tal intervalo entre a origem da vida e do planeta e a narrativa da Bíblia, encontra certa semelhança com o chamado Criacionismo de Intervalo - Gap Creationism(SCOTT, 2009). De acordo com Scott (2009), essa versão do criacionismo data do final do século XVIII e preconiza que há um imenso intervalo temporal entre o primeiro e o segundo versículo do primeiro capítulo do livro de Gênesis. Uma criação pré-adâmica teria sido destruída, sendo seguida pela criação do mundo em seis dias e de Adão e Eva. Nesse sentido, abre-se a possibilidade para o reconhecimento de evidências que apontam para uma Terra antiga, em oposição às versões de criacionismo de Terra jovem que defendem que o planeta tem entre seis e dez mil anos de idade. Scott (2009) acrescenta ainda que para o criacionismo de intervalo, os seis dias do Gênesis e os subsequentes seriam intervalos de vinte e quatro horas (o que P5 não afirma).

As evidências científicas são usadas por P5 ora para criticar o relato bíblico, ora para defender que poderia ser possível analisá-los conjuntamente.

P5: Então, lá na criação bíblica você não tem a criação dos dinossauros, por exemplo, e a gente sabe que os dinossauros existiram...[...] Tem até alguns que dizem que os dinossauros eram as bestas-feras que não entraram na arca de Noé, mas, ao meu ver, não tem como ter... Só que dinossauro existia... Como é que pode isso?

P5: Hoje em dia não sei se tem alguma pesquisa em cima dessas teorias da origem da vida, mas os cientistas acabaram e as pessoas acabaram pesquisando individualmente $e$ até hoje eu não vi nenhuma pesquisa que tenha parado pra analisar em conjunto... Pra saber se tem uma ligação um com outro... Então, eи acredito que possa existir uma ligação com a outra. Agora, dizer assim, realmente, o que eu acredito... É meio complicado porque eu acredito um pouco nas duas partes... Então, fica meio difícil... Eu acho que possa ser que tenha uma ligação entre uma coisa e outra.

No primeiro trecho, ele critica a Bíblia porque esta não fala sobre o surgimento dos dinossauros. Ele ainda pondera, dizendo que há quem defenda que as bestas-feras que não entraram na arca de Noé poderiam ser os dinossauros, mas 
discorda disso, porque estes, em sua opinião, de fato existiram. Já no segundo, ele fala que cientistas teriam realizado estudos sobre a origem da vida, bem como "não-cientistas", mas se queixa que não há pesquisas que tenham analisado ciência e religião em conjunto. Embora ele afirme que acredite, em parte, em ambos os lados, P5 também diz especula que possa haver uma ligação entre as pesquisas científicas e os relatos religiosos. Nesse sentido, as evidências científicas atuam tanto no sentido de questionar o criacionismo e dar suporte à evolução, quanto em uma possível articulação com o conhecimento religioso para alcançar uma explicação unificada sobre a origem da vida.

Outro ponto de grande importância para a visão de P5 é usar o termo "teoria" como uma explicação pouco sólida, ao se referir às explicações sobre a origem da vida quando questionado que ideias lhe eram mais fortes quando se fala de criacionismo.

P5: [...] Eu acho que ainda existe muita coisa a ser estudada na evolução pra haver realmente uma comprovação. [...] É por isso que eu sempre falo, tudo é uma teoria. Indícios levam a acreditar naquilo dali. Mas nenhuma é uma lei. A lei foi realmente comprovada. Então, por isso que eu acho que a evolução tem que ser bem estudada pra gente saber mesmo o que aconteceu. Se há uma ligação entre a parte bíblica com a parte científica.

Neste trecho, o professor indica que a teoria da evolução não foi comprovada e, por isso, não podemos ter certeza dela. Apenas após uma comprovação é que ela alcançaria o status de lei e saberíamos, de fato, como se deu a origem e evolução dos seres vivos. Tais afirmações se aproximam de uma visão de ciência muito presente no senso comum (CHALMERS, 1999) de que o método científico pode conduzir à verdade e que haveria uma diferença hierárquica entre teorias e leis. Assim, a teoria evolutiva é vista por P5 como uma explicação baseada em "indícios" - palavra que denota menos força do que "evidências" ou "provas", por exemplo - e que, por não ser comprovada, não teria tanta credibilidade. Dessa maneira, a teoria evolutiva e a explicação bíblica lhe parecem ter poderes explicativos semelhantes e, por isso, sente-se mais confortável em adotar uma postura que mescla elementos de ambas, o que é evidenciado quando diz que acredita "um pouco nas duas partes" - trecho anterior - e que pode haver uma "ligação" entre elas.

Se o docente, por um lado, levanta dúvidas sobre a validade da teoria da evolução, por outro também faz críticas à Bíblia que o impulsionam a rejeitar visões literalistas do livro sagrado dos cristãos. Além da ausência dos dinossauros, 
discutida anteriormente, ele aponta que houve problemas de tradução da obra, que esta já foi usada como instrumento de dominação em outras épocas e que há incoerências, como o fato de Adão e Eva terem encontrado outros seres humanos ao serem expulsos do Éden.

P5: Existem fatos que não podem ser explicados na Bíblia, como por exemplo, a própria criação. Deus criou Adão e Eva, depois expulsou eles do Paraíso... Quando expulsou eles do Paraíso, eles encontraram uma outra civilização. Se eles foram os primeiros a serem criados, como existia outra civilização?

Dessa maneira, é possível perceber que, tal qual os outros docentes, P5 também flexibiliza os conhecimentos científico e religioso para conciliá-los. Essa atitude envolve uma reflexão sobre ambos que, ainda que possa ser criticada, indica que não aceita nem a teoria evolutiva, nem o criacionismo como conceitos fechados e inquestionáveis.

Em síntese, P5 aceita que a evolução ocorra, mas acredita que Deus é quem permite isso. Para conseguir conciliar a teoria evolutiva e a ação divina, ele vai além e diz que é possível que a narrativa bíblica se inicie após a extinção dos dinossauros, o que forneceria suporte para a existência de fósseis e para a idade antiga da Terra. Ele acrescenta que as evidências científicas podem apoiar tanto a evolução quanto o criacionismo e que só se poderia chegar à verdade estudando ambos em conjunto. Por fim, a Bíblia também deve ser vista de forma cautelosa, já que possuiria incoerências que comprometeriam alguns de seus relatos.

\section{7}

\section{Concepções e estratégias de P6: a evolução junto com a criação}

O professor P6 é batista e tanto seu pai quanto sua mãe trabalharam na liderança de sua igreja. Embora hoje esteja afastado, já fez parte do Ministério do Louvor, grupo responsável pelas músicas que são tocadas durante os cultos. Ainda que a Igreja Batista tenha sido uma das denominações com maior número de fiéis ligados ao Fundamentalismo nos EUA no início do século XX (NUMBERS, 2006), a visão de P6 sobre a origem e evolução da vida une elementos científicos e religiosos, conforme indica no mapa conceitual da Figura 4.7. 


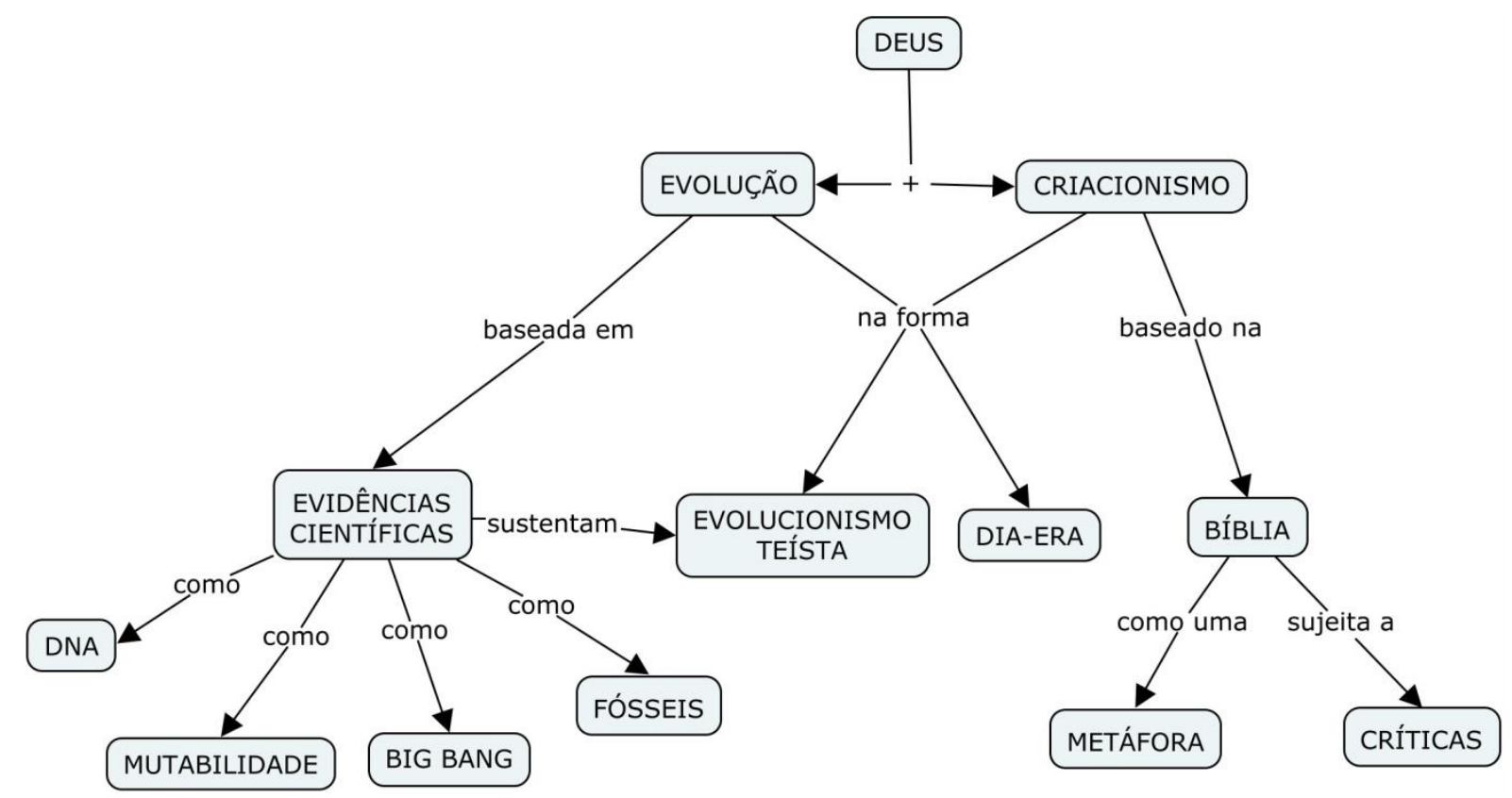

Figura 4.7: Estratégias de P6 para conciliar criacionismo e evolução.

Para P6, Deus age tanto na evolução quanto na criação e estes dois processos ocorrem ao mesmo tempo:

\section{P: $O$ que te vem mais forte à cabeça quando falamos de evolução?}

P6: É como eu falo para os meus alunos... Quando os meus alunos me perguntam: professor o que você acha da evolução? Eu acredito que a evolução, ela veio junto com a criação. Não existe uma coisa separada da outra. Quando Deus fala que criou o mundo em sete dias. Quem estava lá pra contar? Foram períodos. Mas, se você for observar na Bíblia, a evolução, ela vem gradativamente. Deus vem criando as coisas gradativamente... Então, está tudo interligado. É claro, não foi criado em sete dias. [...] A questão do tempo também ali é outro. O tempo de Deus não é o tempo do homem. Então, está tudo muito ligado.

O professor P6 afirma que expõe aos seus alunos - fato a que retornaremos em outro momento - que acredita que a evolução e a criação ocorrem ao mesmo tempo, guiadas por Deus. Ele ainda se remete, como P3, aos dias da atividade criativa narrados no Gênesis como uma metáfora para longos períodos de tempo criacionismo de dia-era (SCOTT, 2009) - e que Deus atua e continua atuando de forma gradual. Ele afirma, duas vezes, que a teoria evolutiva e o criacionismo estão interligados, alegando que é possível perceber tal ligação nos textos bíblicos.

Vale a pena destacar, também neste trecho, a indagação de P6 de "quem estava lá pra contar?". Tal qual P2, esta frase evidencia a observação direta como forma de se construir conhecimento e descrever um fenômeno em detrimento de formas indiretas de estudo. Esta perspectiva o faz rejeitar parcialmente as teorias científicas de origem da vida, já que estas são sustentadas por evidências indiretas 
e experimentos de laboratório baseados em inferências da constituição da atmosfera primitiva terrestre.

Em sua entrevista, quando perguntado se já havia tido dificuldades de conciliar seus estudos de biologia com suas crenças religiosas, ele diz que não, porque sempre procurou ver a evolução associada ao criacionismo.

P6: Eu era garoto e eu já pensava dessa forma. Eu não pensei isso por conta da faculdade, eu pensava isso já muito antes mesmo. Muito antes do colégio. Muito antes do colégio técnico. Eu chegava e questionava muito. "Eu gosto de biologia, eu acho que foi dessa forma. Por que que não pode encaixar?”[...]

P: Você acha que algum momento você já sentiu dificuldade em conciliar a sua fé com os estudos em biologia?

P6: Não. Não por conta da forma que eu sempre pensei. Nunca. Nunca mesmo.

P: Nem na escola, nem na universidade...

P6: [...] Eu tive alguns problemas ao falar com os mais velhos na igreja, deles torcerem o nariz, deles falarem: "Não. Isso aí está errado!" Mas isso aí nunca me abalou, nunca foi dificuldade pra mim. Porque eu pensava daquela forma e ninguém ia mudar a minha cabeça e ninguém mudou a minha cabeça.

É interessante notar que P6 afirma que desde jovem gostava de biologia e procurava fazer questionamentos à visão hegemônica em sua comunidade religiosa sobre a origem da vida. Ainda que tivesse que lidar com a resistência de pessoas mais velhas, ele diz que mantinha sua posição e que fez o mesmo durante sua formação universitária. Tal relato indica que, mesmo que a doutrina e a comunidade religiosa em que um fiel está inserido tenham um determinado referencial, isto não implica em uma aceitação automática desses pressupostos.

O docente P6 ainda indica que determinadas evidências científicas e características dos seres vivos podem ser vistos como fruto da ação de Deus.

\begin{abstract}
P6: Eu acho que a grande obra-prima de Deus foi o DNA e, através dele, Ele fez que os seres evoluíssem. [...] Sim, foi Deus quem criou tudo, mas foi Deus quem criou a capacidade de um ser mutável, a capacidade de um ser se adaptar, capacidade de um ser poder superar algumas barreiras como nós seres humanos superamos. A barreira do frio, a gente constrói casacos... Deus nos deu essa capacidade. [...]

Eu acredito que o criacionismo está junto com a questão do Big Bang. Está intrínseco, está ligado... [...] Deus criou o mundo, mas criou o mundo através do Big Bang... Através dos tempos que passaram e das evoluções que surgiram, através dos seres que foram caindo e outros seres que foram se levantando. Não teria outra explicação para os dinossauros, não teria explicação para os fósseis que existem hoje.
\end{abstract}

Inicialmente, o professor afirma que o DNA é "a grande obra-prima de Deus" e que, por meio desta obra, Ele faz com que os seres vivos evoluam. Nesse sentido, o fato de todos os seres vivos possuírem DNA - que seria, a princípio, uma evidência científica da ancestralidade comum entre todas as espécies - é interpretado como um indício da atuação divina. 
Em seguida, também se refere à capacidade de um organismo ser mutável - mutabilidade - como uma evidência da ação de Deus. Neste ponto, contudo, P6 apresenta uma concepção de "adaptar-se" distinta da visão científica. Enquanto o professor associa adaptação à capacidade de superar dificuldades impostas pelo ambiente, de acordo com Futuyma (2005), é um processo de mudança genética em uma população, no qual, como resultado da seleção natural, a população se tornou mais bem adequada a uma determinada característica do ambiente. Esta concepção do professor já foi indicada por diferentes pesquisas e se mostra como um dos pontos mais comuns de dificuldade de entendimento da teoria evolutiva em função de seu significado distinto do senso comum (SANTOS, 2002; SMITH, 2010b).

Um terceiro aspecto importante contido na fala de P6 é a afirmação de que o Big Bang e a criação estão intrinsecamente ligados. Deus não só guiou e guia esses dois fenômenos, como também o faz em relação à evolução - o que P6 já havia declarado anteriormente. Ele acrescenta, ainda, que essa é a única explicação que ele percebe como possível para se entender a existência dos fósseis de dinossauros, isto é, a existência de fósseis de seres extintos evidencia a ação de Deus no processo evolutivo, de acordo com o professor.

Em síntese, P6 acredita que Deus atuou e atua tanto na evolução como na criação, processos que estão interligados, perspectiva que se aproxima do evolucionismo teísta (SCOTT, 2009). Além disso, também crê que os seis dias da criação narrados no Gênesis são, na verdade, longos intervalos de tempo, pois " $o$ tempo de Deus não é o tempo do homem", concepção que se aproxima do criacionismo de dia-era. Sua argumentação para sustentar sua visão se baseia na flexibilização de conhecimentos científicos e religiosos. Por um lado, ele reconhece a validade de diferentes evidências científicas, porém as associa a Deus. Por outro, não lê a Bíblia de forma literal e também levanta críticas a algumas de suas narrativas. Essa estratégia parece lhe conferir conforto e segurança, uma vez que parece superar possíveis conflitos entre religião e ciência que P6 poderia ter. 


\section{8 \\ Semelhanças e diferenças entre os professores que conciliam suas crenças religiosas com suas ideias sobre evolução}

Ao analisarmos os dados dos professores como um todo, encontramos semelhanças e diferenças entre eles no que concerne às estratégias utilizadas para conciliar a evolução e o criacionismo. No Quadro 4.1, estão sintetizadas as estratégias de acordo com os docentes e nove critérios que foram expressos por eles em suas entrevistas.

Os critérios utilizados foram:

(i) $\mathrm{O}$ uso de evidências científicas para sustentar a concepção de criacionismo;

(ii) Leitura da Bíblia (literal ou não-literal);

(iii) Evolucionismo teísta (se adota ou não o evolucionismo teísta);

(iv) Conflito (se já sentiu conflito interno com relação à origem e evolução da vida);

(v) Deus ou força (de que maneira o(a) entrevistado(a) se refere à entidade transcendente envolvida na origem e evolução da vida);

(vi) Criacionismo de dia-era (se sua visão se aproxima desta concepção de criacionismo);

(vii) Criacionismo de intervalo (se adota o criacionismo de intervalo);

(viii) Flexibilização do conceito de teoria (se utiliza teoria com o sentido de uma afirmação sem a necessária sustentação ou se também denomina o criacionismo como uma teoria);

(ix) Evolução espiritual (se se remete a uma concepção de evolução ligada ao espírito de seres vivos). 


\begin{tabular}{|l|l|l|l|l|l|l|l|l|l|l|}
\hline PROF. & RELIGIÃo & $\begin{array}{l}\text { EVID. } \\
\text { CIENT. } \\
\text { CRIAC. }\end{array}$ & $\begin{array}{l}\text { LEITURA } \\
\text { DA BíBLIA }\end{array}$ & $\begin{array}{l}\text { EVOL. } \\
\text { TEíSTA }\end{array}$ & CONFLITo & $\begin{array}{l}\text { DEUS OU } \\
\text { FORÇA }\end{array}$ & $\begin{array}{l}\text { CRIAC. } \\
\text { DIA-ERA }\end{array}$ & $\begin{array}{l}\text { CRIAC. DE } \\
\text { INTERV. }\end{array}$ & $\begin{array}{l}\text { FLEX. } \\
\text { TEORIA }\end{array}$ & $\begin{array}{l}\text { EVOL } \\
\text { ESPIRIT. }\end{array}$ \\
\hline P2 & Católica & Sim & Não-literal & Sim & $\begin{array}{l}\text { Sim, mas diz } \\
\text { que não }\end{array}$ & Deus/Força & Não & Não & Sim & Não \\
\hline P3 & Católica & Sim & Não-literal & Sim & Não & Deus & Sim & Não & Não & Não \\
\hline P4 & $\begin{array}{l}\text { Sem } \\
\text { religião }\end{array}$ & Sim & Não-literal & Sim & $\begin{array}{l}\text { Sim, mas diz } \\
\text { que não }\end{array}$ & Deus/Força & Não & Não & Não & Sim \\
\hline P6 & Católico & Sim & Não-literal & Sim & Não & Deus & Não & Sim & Sim & Não \\
\hline
\end{tabular}

Quadro 4.1: Estratégias dos professores P2, P3, P4, P5 e P6 para conciliar evolução e criacionismo. 
Três critérios são atendidos por todos os professores, ainda que o façam de forma distinta: o uso de evidências científicas para sustentar suas concepções de criacionismo; a leitura não-literal da Bíblia e o evolucionismo teísta. Essas três categorias nos parecem indicar um esforço no sentido de flexibilizar tanto o conhecimento religioso quanto o científico. A margem para possíveis flexibilizações é relativa, dado que nenhum dos professores aqui pesquisados deixou sua fé completamente de lado, por mais que suas crenças religiosas não encontrassem suporte em evidências científicas para todas as suas alegações. Em outras palavras, os sujeitos parecem dispostos a abrir mão de determinados elementos (como uma leitura literal da Bíblia, por exemplo), mas não de outros (como a existência de Deus e de seu envolvimento na origem e evolução da vida).

Em relação à experiência de conflitos entre suas crenças religiosas e seus estudos, todos os professores dizem que nunca passaram por isso. Contudo, P2 e P4 dão indícios, ao longo de suas entrevistas, de certa dificuldade em definirem seus pensamentos por acreditarem em elementos tanto da visão científica quanto da religiosa. Da mesma maneira, apenas estas duas professoras indicam que poderiam definir a entidade transcendente em que acreditam tanto como Deus quanto como Força, enquanto que todos os outros professores optam pela primeira nomenclatura. P3 e P6 se remetem ao criacionismo do dia-era, enquanto os outros professores não o fazem. Já possíveis aproximações ao criacionismo de intervalo são feitas exclusivamente por P5 o qual, juntamente com P2, utiliza o conceito "teoria" de maneira pouco rigorosa, ora para desvalorizar a teoria evolutiva, ora para valorizar o criacionismo. Por fim, apenas P4 se refere a uma possível evolução espiritual entre os seres vivos, provavelmente devido à influência do espiritismo sobre suas crenças pessoais.

Tal complexidade de categorias e de como cada um dos indivíduos investigados as utilizam, dificultam a formulação de tipologias. É possível afirmar, porém, que algumas aproximações verificadas independem da religião declarada pelos participantes. Este parece ser o caso de P3 (católica) e P6 (batista) que, ainda que apresentem variações de abordagem dentro das categorias aqui apontadas, coincidem em todos os critérios apresentados no Quadro 4.1. Fenômeno semelhante é observado entre P2 (católica) e P4 (sem religião) que se assemelham em sete dos nove critérios destacados. Por outro lado, P2 e P3, ambas católicas, só compartilham cinco. 
Podemos apontar, contudo, que os professores P2, P3, P5 e P6 tendem a utilizar argumentos científicos e religiosos de forma complementar. Isto é, utilizam um deles até certo ponto, quando expressam dúvidas ou críticas. Nesse momento, lançam mão do outro, em um processo de complementação. Tal forma de coexistência entre diferentes verdades, é tratada por Bobbio (2002) como ecletismo e parte da ideia de que nenhum sistema de pensamento é completamente verdadeiro ou falso. Referindo-se mais especificamente aos debates ciência e religião, Evans, Legare e Rosengren (2011) chamam de raciocínio paralelo (parallel reasoning) o uso de duas ou mais epistemologias para explicar resultados iguais ou semelhantes. Por outro lado, a professora $\mathrm{P} 4$, ao promover o cruzamento de diferentes epistemologias, muitas vezes de forma bastante confusa, realiza o que Bobbio (2002) denomina sincretismo e Evans, Legare e Rosengren (2011) justaposição (juxtaposition). Assim, há em sua fala um sentido de convergência ao mesmo tempo em que usa diferentes epistemologias de maneira desordenada.

\section{9 \\ Conclusão}

Enquanto que P1, mais claramente, e P7 tendem a tratar evolução e criacionismo como plenamente distintos, os outros cinco professores apresentam visões que misturam elementos de ambas as formas de pensamento em diferentes e complexas combinações. P2 se baseia em um sentimento de conexão com uma entidade transcendental e na ideia de que não estamos sozinhos no universo, para justificar sua crença em um agente criador, cuja obra pode ser explicada através de diferentes teorias. P3, por sua vez, crê que Deus atuou e atua tanto na criação como na evolução, de maneira distinta da contada na Bíblia, mas que há evidências científicas para dar suporte a uma visão de mundo criacionista. Já P4, usa elementos do cristianismo, do espiritismo e da própria ciência para formular sua visão acerca da origem e evolução da vida na Terra, para afirmar que crê que Deus, ou uma força, cria e é, ao mesmo tempo parte da criação que, além do processo de evolução biológica, está inserida em uma evolução espiritual. O professor P5 declara que Deus toma parte na criação e na evolução. Ele aponta uma série de críticas à Bíblia e sugere que uma leitura que se aproxima do 
criacionismo de intervalo pode tornar as evidências científicas compatíveis com o livro do Gênesis. Finalmente, P6 afirma que evolução e criacionismo ocorrem ao mesmo tempo, guiados por Deus, cuja obra-prima teria sido o DNA. Conjugada a esta concepção, está o pensamento de que o livro sagrado dos cristãos deve ser lido de forma metafórica e é passível de críticas.

Como pretendemos discutir nos capítulos futuros, compreender as formas como os professores concebem criacionismo e evolução parece ser de grande importância para entender a maneira como desenvolvem as práticas pedagógicas relacionadas a esse tema. As dinâmicas envolvidas em cada turma, também dependem do perfil dos estudantes que, em alguns casos, podem se manifestar abertamente em oposição ao professor ou, mais frequentemente, permanecerem em silêncio, mesmo que discordem do que está sendo ensinado. 


\section{5. \\ Concepções dos(as) estudantes sobre criacionismo e evolução}

Após termos descrito e discutido as concepções pessoais dos(as) professores(as) participantes da pesquisa, no presente capítulo analisaremos as visões dos(as) estudantes. Utilizaremos os dados obtidos ao longo das observações do campo, nas entrevistas (a lista de temas e códigos utilizados na análise podem ser vistos no Apêndice 9) e no questionário aplicado. Nossa intenção é explicitar as principais ideias expressas pelos alunos para que possamos compreender o perfil dos envolvidos em sala de aula e que fatores poderiam indicar a possibilidade de conflitos e resistência à aprendizagem das teorias científicas sobre a origem e a evolução da vida.

Ao longo deste trabalho temos defendido, baseados em outras pesquisas, que o ensino da teoria evolutiva neodarwinista deve estar orientado para o entendimento de conceitos científicos e não para a mudança das crenças religiosas dos estudantes. Assim, estudar as características das concepções dos(as) educandos(as) nos parece de grande importância para entender que questões o(a) professor(a) pode vir a abordar para ressaltar as diferenças entre a produção de conhecimentos científicos e religiosos, evitando, por um lado, uma abordagem cientificista e, por outro, um relativismo que considere ciência e religião como epistemologias igualmente válidas para o ensino de biologia.

\section{1}

\section{As concepções dos estudantes entrevistados}

Ao longo das entrevistas semiestruturadas com os(as) estudantes perguntamos-lhes como acreditavam que a vida havia surgido em nosso planeta e, posteriormente, sobre o surgimento dos humanos. Muitos alunos indicaram ter uma visão pessoal próxima de uma leitura literal da Bíblia, de modo que respondiam a ambas as questões em uma única resposta. Dessa maneira, optamos 
por apresentar os dados relativos a esses dois temas em um único tópico. Porém, ressaltamos as diferentes abordagens dadas pelos entrevistados, pois, de acordo com pesquisas anteriores (OLIVEIRA; BIZZO, 2011; SMITH, 2010a), há maior resistência à evolução humana do que a de outros seres vivos.

Em uma consideração mais ampla, onze estudantes deram declarações que os aproximam de uma visão literal do Gênesis, um do criacionismo do dia-era, seis mesclam concepções científicas e religiosas e dois manifestam visão mais próxima da científica. Como procuraremos mostrar, há distinções no interior desses grupos que, por vezes, tornam difíceis enxergar com clareza as fronteiras entre essas categorias.

A maior parte dos estudantes entrevistados disse acreditar no relato literal do Gênesis, sendo um católico (A2), um sem religião (A10) e nove evangélicos (A6, A7, A9, A12, A14, A16, A17, A18, A19). Esses alunos indicaram, de maneira geral, acreditar que Deus criou o universo, a Terra, os seres vivos, incluindo o ser humano, em sete dias (intervalos de 24 horas). A fala de A2 sintetiza essas ideias:

P: Para você, como surgiu a vida no nosso planeta?

A2: Que pergunta difícil... [...] Eu acredito em Adão e Eva, pecado capital, eu acredito. P: Acredita em quê?

A2: Que Deus fez a terra em sete dias e que no último foi descansar e que foi fazendo as coisas. Fez a luz, fez o sol... Eu acredito nessa criação. Eu acho que a teoria do criacionismo, né, que fala da criação de sete dias, eu acredito muito... Não do evolucionismo, né?

P: Então você concorda com o que está na Bíblia?

A2: Sim.

$P:$ Mesmo falando ali de sete dias?

A2: Lógico.[...] Eu não sei se é essa história que apresenta o Big Bang... E foi lá e explodiu e aí a Terra se fez... Aí a espécie que estava lá na água foi crescendo e ok... Mas como ela cresceu? Ok... Eu posso até estudar, aprender, que existiram micro-organismos, talvez a temperatura do sol e tudo aquilo que estava... Ok, mas como é que a espécie que hoje chegou ao que nós vivemos nasceu daquilo ali? Lógico, não recrimino as pessoas que acreditam nisso, mas eu também não acho muito plausível.

Neste trecho, o estudante inicia dizendo que a vida e o nosso planeta surgiram pela atuação de Deus. É importante notar que, em sua visão, o criacionismo é mais plausível do que as teorias científicas sobre a origem e a evolução da vida. Ele argumenta que, ainda que estude as condições para o surgimento dos primeiros organismos vivos, continua acreditando que as teorias científicas não conseguem explicar como eles surgiram. Não seria possível, portanto, que não houvesse um agente criador por trás desses processos. Chama atenção, ainda, o fato de o aluno se referir ao criacionismo como uma teoria, algo 
que seu professor de biologia (P1) também fez em sala, como discutiremos no capítulo 6.Para Evans, Legare e Rosengren (2011), essa visão poderia ser considerada como de dois modelos culturais que competem entre si (ciência e sobrenatural) com domínio do sobrenatural. Assim, para estes estudantes, evolução e criacionismo estariam localizados em polos opostos, com visões que não seriam conciliáveis.

Quatro estudantes (A6, A7, A16 e A19, evangélicos) reforçam em suas falas a importância da fé e das crenças pessoais para se aceitar o criacionismo. Já as alunas A6 e A14 (evangélica) indicam que os cientistas rejeitam a religião, argumento que também utilizam para não aceitarem a teoria evolutiva neodarwinista. Por sua vez, A6 e A7 destacam a influência de familiares e amigos para a construção de suas concepções. A fala de A6, a seguir, reúne diversas dessas ideias:

\begin{abstract}
P: Em algumas aulas de biologia se fala sobre teoria de origem da vida. $O$ professor às vezes fala de uma teoria que não necessariamente tem a interferência de Deus ali. $O$ que você acha disso? Como você se sente quando o professor fala disso?

A6: [...] Eu ainda acho que foi Deus que criou o mundo. Eu cresci com isso. Mas eu não julgo os cientistas que acham isso, que não têm religião, que éateu. Eles querem justificativas. Porque a religião, o evangelismo é complicado, porque você tem que ter fé pra acreditar. Tem que ter fé, tem que sentir. Tem que ter fé pra acreditar. Ele fez o homem pelo barro. Foi gerando o homem, mas sim, tem alguns cientistas que acharam rastros de barro na gente, no nosso corpo e eles não conseguem explicar isso. Minha colega falou. É complicado sim, mas é uma questão de fé.
\end{abstract}

Inicialmente, a estudante afirma que, mesmo após as aulas, permanece acreditando que Deus criou o mundo. Ao dizer que cresceu com essa visão de mundo, sinaliza que dá mais importância aos ensinamentos de sua religião do que às aulas de biologia que assistiu sobre a origem e evolução da vida. Em seguida, declara que não julga os cientistas que aceitam as teorias científicas, sugerindo que estes não têm religião e são ateus. Já em um terceiro momento, diz os cientistas querem justificativas e que o evangelismo seria complicado porque precisaria ter fé para acreditar. Dessa maneira, como os cientistas não teriam fé, não conseguiriam acreditar no criacionismo. Por fim, ela acrescenta que, de acordo com uma amiga sua, pesquisadores encontraram vestígios de barro nos humanos, o que seria um indício da atuação de Deus, através de uma evidência científica. Ou seja, ao final, ela tenta justificar sua crença com uma explicação que seria científica, levantando suspeita sobre a teoria que ela não acredita por motivos de fé e que justificaria seu posicionamento religioso. 
Em sua fala diversos fatores se cruzam com sua crença religiosa para cumprir uma dupla-função: dar suporte ao criacionismo e rejeitar as teorias científicas de origem e evolução da vida. Ao dizer que os cientistas não têm religião, sugere que ciência e religião se excluem, pois não seria possível ser cientista e religioso ao mesmo tempo. Assim, a aluna estabelece uma fronteira clara entre pessoas que possuem uma crença de um lado e pesquisadores do outro. Quando afirma que os cientistas querem justificativas e o evangelismo demanda fé, pode-se inferir que aqueles que têm fé no evangelismo não precisam de justificativas para possuírem suas crenças. Mesmo assim, argumenta utilizando uma suposta evidência do mundo natural, de que os seres humanos teriam vestígios de barro em seus corpos. Vale destacar, ainda, a importância dada a sua amiga como uma fonte segura para fazer afirmações sobre pesquisas científicas. A6 poderia pensar que o professor de biologia seria um interlocutor mais adequado para obter informações sobre pesquisas acadêmicas. No entanto, como os conhecimentos discutidos pelo docente contrariam suas crenças pessoais ou ele seria um daqueles que não tem fé, ela privilegia sua amiga, que implicitamente parece ser também religiosa e que a ajuda a fortalecer sua concepção criacionista para o surgimento dos seres humanos.

No interior deste primeiro grupo, há ainda seis estudantes (A6, A7, A14, A16, A17, A18) que declaram não aceitar a teoria neodarwinista para a evolução humana, porque esta diria que os "humanos vieram dos macacos". A14 e A18 dizem que achavam "engraçado" que os humanos pudessem ter surgido de macacos e A17 disse achar "estranho". Já A6 e A7 dizem que se o ser humano surgisse do macaco, ainda haveria macacos se transformando em seres humanos, o que não estaria ocorrendo. A16, por sua vez, argumenta que assim como os egípcios adoravam outros deuses e estavam errados, a ciência igualmente está errada quando defende que os seres humanos também passaram por um processo evolutivo:

A6: Eu não acredito nesse negócio de macaco. Pra deixar bem claro. [risos] Sim, o macaco é bem inteligente, muito inteligente. Só que se tivesse esse negócio de que o homem surgiu do macaco, teria macaco agora? Teria algum macaco agora? Não teria. Foi uma teoria pra mim que já devia ter acabado, entre aspas, há muito tempo, porque não tem justificativa. Como? Surgir do macaco... Porque se surgisse do macaco, o macaco ia se transformar em homem com o decorrer do tempo e não aconteceu isso. 


\begin{abstract}
P: Você disse que tem gente que diz que o homem vem do macaco e que isso é mentira. Me explica porque você acha que isso é mentira?

A16: Porque eu acho meio improvável que seja isso. [...] Eu não tenho uma resposta concreta pra isso, mas eu acho que não é verdadeiro que a pessoa vem do macaco e tem outras pessoas que falam que... Na época do Egito, essas coisas assim... Que antigamente as pessoas adoravam outros Deuses, que o Faraó... Essas coisas assim... Deus de estátua, cada um... Um Deus de imagem e o nosso não tinha, aí o nosso, criticavam... Falavam e agora, com a evolução que está tendo agora, as pessoas falam que o ser humano veio do macaco... Pra mim isso não é certo... Pra mim é mentira [enfatiza o tom de voz]. $O$ pessoal inventa uma coisa que não tem nada a ver. O certo mesmo é que Deus criou a gente, fez Adão e Eva e tudo. A origem da vida foi Deus quem nos criou.
\end{abstract}

Embora a premissa de que "os seres humanos vieram dos macacos" não seja correta do ponto de vista científico, nem seja postulada pela teoria evolutiva neodarwinista, é interessante notar que o argumento sustentado por A6 e A7, ainda que motivado por uma concepção religiosa, baseia-se em elementos do mundo natural, derivadas de suas próprias experiências (observação de que os macacos não estão se transformando em humanos). Por outro lado, a argumentação de A16 se baseia exclusivamente em sua concepção religiosa e não em evidências do mundo natural. Essas diferentes formas de resistir à teoria evolutiva neodarwinista também foram apontadas por Thagard e Findlay (2010). Esses autores destacam que há obstáculos cognitivos (dificuldades conceituais, metodológicas e de coerência) e obstáculos emocionais (ligados a fatores psicológicos e/ou religiosos). No caso de A6 e A7, a resistência se dá em função de dificuldades conceituais do processo evolutivo e de entendimento da metodologia científica. No caso de A16, a resistência se dá por um fator emocional e religioso, tendo em vista que rejeita a visão científica para a origem dos seres humanos porque esta se desvia da verdade estabelecida por Deus.

Três estudantes (A1, A3 e A20, evangélicas) manifestam uma visão que mescla elementos religiosos e científicos, porém demonstram incertezas de como se articulam. Elas dizem tender a acreditar na Bíblia, mas creem que determinados conhecimentos científicos sobre as origens também fazem sentido:

\title{
P: Como é que você acha que surgiu a vida no nosso planeta?
}

A1: Na Bíblia diz que teve Adão e Eva. Eu não sei direito. Primeiro Ele botou... Há fogo, depois há Terra... Há não sei o quê... Há luz. E aí foi criando a Terra, mas na ciência diz que foi através do Big Bang que foi surgindo às coisas... Que explodiu o Sol, não sei o quê. Mas eu acho que foi através de Deus e a ciência ajudou.

P: Como é que você acha que surgiram os seres humanos no nosso planeta?

A1: Através de Adão e Eva [ri levemente].

P: Você deu risinho quando você falou de Adão e Eva?

A1: Porque as pessoas não acreditam. Falam que foi através dos homens sapiens sapiens, né?

P: E o que você acha quando as pessoas dizem isso? 
A1: Eu acho que foi... A gente não estava pra saber se Adão e Eva é realmente assim como o homem formado... Não! Vai que Adão e Eva era um homem sapiens sapiens que foi evoluindo e que aos poucos chegou como a gente é agora. Por uma evolução.

A1 responde à primeira pergunta dizendo que a Bíblia fala de Adão e Eva das etapas da criação divina. Em seguida fala da visão científica, remetendo ao Big Bang, entendido como "explosão do sol". Logo depois, diz que teria sido Deus, mas que a ciência teria "ajudado". Nas questões seguintes, ao abordar a existência de Adão e Eva, a educanda diz que é possível que estes tenham existido, mas tenham sido, também parte do processo evolutivo dos seres humanos atuais.

É possível perceber que A1 reconhece a validade de determinados elementos do pensamento religioso e do científico. Isso é evidenciado quando a aluna diz que acredita que a vida surgiu "através de Deus e a ciência ajudou", ainda que a ciência em si apenas busque estudar as condições para a origem da vida e não tenha atuado diretamente nesse processo há bilhões de anos. Um segundo ponto importante a ser destacado é que a estudante ressalta que ninguém estava presente para atestar se Adão e Eva de fato existiram. A aluna enfatiza a observação direta como forma de se construir conhecimento definitivo sobre um determinado fenômeno, tal qual P2 e P6 - discutidos anteriormente. Contudo, ao contrário desses docentes, ela usa tal argumento para levantar dúvidas sobre a existência de Adão e Eva, algo que reforça ao considerar a possibilidade de eles terem feito parte da evolução humana.

Essa visão se aproxima da noção de sincretismo, explicitada por Bobbio (2002), ao se referir a concepções pluralistas de verdade que usam de várias doutrinas, aparentemente opostas, para conciliá-las, fundi-las ou confundi-las em uma só. Mais especificamente sobre o relacionamento entre evolução e criacionismo, Evans, Legare e Rosengren(2011) chamam de justaposição (juxtaposition) a forma de coexistência de crenças científicas e sobrenaturais em que ambas são usadas para explicar o mesmo fenômeno de forma não necessariamente organizada. As concepções dessas estudantes, pois, ainda que demonstrem dúvidas, apontam no sentido de que evolução e criacionismo não seriam obrigatoriamente rivais, como o defendia o grupo anterior.

Um estudante (A15, evangélico) manifestou em sua entrevista uma posição mais próxima do criacionismo de dia-era (SCOTT, 2009): 
P: Como você se sente, por exemplo, quando uma professora vai dar uma aula de origem da vida, evolução e ela fala explicações que não envolvem Deus pra surgir a vida?

A15: Aí eu mesmo, na minha própria cabeça, eu tento encaixar com o que a Bíblia diz, entende?

P: Como assim? O que você pega de um e o que você pega de outro pra encaixar?

A15: Por exemplo, o negócio do tempo. Como para Deus foram sete dias o que ele criou, pode ter sido toda a formação da Terra para nossa vista foram milhões, milhões de anos. E que pra Deus ele fez assim [estalou os dedos], mas pra gente, pro nosso ponto de vista foi uma coisa lenta, que nossa formação foi lenta. Digamos que a nossa evolução, a evolução humana, foi como... Pra Deus foi ele montando a gente, enquanto para o nosso ponto de vista, a gente tava evoluindo aos poucos. Eu vou encaixando as coisas assim.

Neste trecho, A15 diz que procura, por conta própria utilizar elementos do conhecimento religioso e do científico para construir sua visão pessoal sobre a origem e a evolução da vida. Ele não descarta a existência e a atuação de Deus nestes processos, todavia destaca que os dias da criação foram, na verdade, intervalos de milhões de anos e não de 24 horas, pois a percepção do tempo para Deus é diferente do ser humano.

Três estudantes (A4 e A8, católicos, e A5, ateu) expressaram visões que os aproximam do evolucionismo teísta (SCOTT, 2009). Eles não aceitam que o universo possa ter surgido a partir "do nada" e atribuem seu surgimento a uma força (no caso de A5) ou de Deus (no caso de A4 e A8). Quanto à origem da vida, A5 acredita que a mesma força também atuou neste processo, enquanto A4 e A8 dizem acreditar que apenas fenômenos naturais estariam envolvidos:

P: Como você acha que a vida surgiu no nosso planeta?

A5: Nesse momento que eu digo que eu sou um pouco agnóstico. [...]Vamos dar um exemplo. Caiu um meteoro e esse meteoro tinha algum tipo de radioatividade e começou a aparecer qualquer tipo de ser vivo, então como surgiu esse meteoro? Do nada? Tudo apareceu do nada? Então de alguma forma, eu acredito que tenha alguma coisa, tenha alguma estrelinha ali que tem a força de alguma coisa, mas hoje eu não chamo ela de Deus.[...] Simplificando, o que eu acredito é que tem alguma força maior, mas eu não a chamo de Deus. Eu não a chamo de nada e eu não acredito nela. Eu só sei que deve existir.Com certeza existe, mas até hoje eu não sei o que é. Como tem muitas pessoas que realmente não sabem, talvez todo mundo não saiba.

\section{P: Como você acha que a vida surgiu no nosso planeta?}

A4: No nosso planeta, eu acho que foi realmente do jeito que a gente tem provas. O que a ciência explica. Da evolução e tal. Eu não acredito que Deus católico ter criado o homem do barro e criou a mulher da costela do homem, eu não acredito nisso. Mas eu acredito que Deus no caso, o Deus que eu acredito... Eu não vou saber diferenciar... O Deus que eu acredito, ele criou o universo e o universo que ele criou propiciou a essência da vida em algum planeta aleatório por acaso acabou sendo a Terra.

O estudante A5, embora tenha se declarado ateu inicialmente, afirma que uma determinada força tenha atuado na origem da vida na Terra. Ele não consegue defini-la com precisão e diz que não acredita nela. Ainda que possa ser incoerente afirmar que algo existe e, ao mesmo tempo, dizer que não se acredita 
nisto, a fala do aluno parece indicar que ele não tem fé religiosa nessa força. Já A4 diz que acredita que a vida tenha surgido em nosso planeta como as teorias científicas descrevem, rejeitando uma leitura literal do Gênesis e as figuras de Adão e Eva. Diferenciando a sua noção de Deus daquela que seria mais comum aos católicos, ele afirma que acredita que este agente transcendental criou o universo com características que favoreceriam o surgimento da vida em algum planeta que, por acaso, foi o nosso.

Ainda com relação a este subgrupo de alunos, A8 argumenta que também considera possível que seres extraterrestres inteligentes tenham atuado no surgimento da vida na Terra:

P: Quando o professor fala que a vida pode ter surgido sem a interferência de Deus, o que você acha disso? Como você se sente?

A8: [...] Eu acho que seria alienígenas, entre aspas. Pelo fato de assistir esses filmes, Prometheus e tudo. Pode ter vindo da mão de um ser, algo maior que poderíamos chamar de alienígenas ou aliens, ETs. Eu acho que pelo fato que dizem ser uma raça inteligente, eu acho que eles conseguiram o dom de dar a vida, então tanto que falam... Igual esse filme Prometheus que teve, que foi a molécula de um deles morto, que cain na árvore quando bateu o raio é que saiu o ser humano. Se Deus não tiver feito isso, eu acho que foi alienígenas.

De todos os estudantes entrevistados, A8 foi o único a levantar a possibilidade da atuação de seres inteligentes de outros planetas sobre a origem da vida na Terra. Citando o filme Prometheus como uma influência para sua concepção, o educando diz que esses alienígenas, por serem inteligentes, conseguiram obter a capacidade de fornecer vida.

É importante notar que, para esses três alunos, determinados processos naturais envolvidos na origem e evolução da vida podem ocorrer sem a atuação de um criador. No entanto, quando eles não conseguem encontrar uma explicação que os satisfaça baseando-se nos conhecimentos científicos, eles recorrem à ideia de que existe um agente criador. Tal qual encontrado por Blancke et al.(2011), esse agente não é necessariamente uma figura baseada em uma visão religiosa, como A5 se refere a uma força e A8 a extraterrestres. Os autores argumentam que esse é um fator intuitivo que se apresenta com um obstáculo possível ao ensino de evolução.

Ainda que apresentem características distintas entre si, é possível encontrar semelhanças entre o pensamento de A15, A4, A5 e A8. Estes quatro estudantes articulam conhecimentos científicos e sobrenaturais de forma mais organizada do que o grupo anterior e, principalmente, defendem uma complementariedade entre 
um e outro. Bobbio (2002) chama este posicionamento de ecletismo, no qual se reconheceria que nenhuma forma de conhecimento é completamente verdadeira ou falsa e, portanto, diferentes pensamentos podem ser usados para completar limitações de outros. Tendo em vista os debates sobre a ciência e o sobrenatural, Evans, Legare e Rosengren (2011) denominam raciocínio paralelo (parallel reasoning) este tipo de coexistência de epistemologias, quando em duas ou mais são usadas para explicar resultados semelhantes ou iguais.

Os dois outros estudantes, A11e A13, manifestaram aceitar as teorias científicas para a origem e evolução da vida na Terra. A11 se declarou católico e quando questionado sobre como achava que a vida tinha surgido em nosso planeta expôs duas visões, uma mais próxima da Bíblia e outra das teorias científicas e disse acreditar em ambas. Em seguida, porém, declarou que tende a acreditar mais de uma concepção da ciência:

\footnotetext{
P: Em algumas aulas de biologia, a professora fala de teorias da origem vida, de como a vida surgiu no nosso planeta e algumas dessas teorias falam que a vida pode ter surgido sem a intervenção de Deus. O que você acha disso? Como você sente quando a professora fala disso?

R: Na minha opinião, nem um, nem outro tá errado. Se for olhar pelo lado da ciência, possivelmente não pode ter sido Deus, mas se for no lado de Deus, na visão, Deus criou a Terra sim.

P: Qual a sua opinião sobre como surgiu a vida em nosso planeta?

$R$ : Eu vou seguir as duas. Eu não tenho nenhuma opinião própria. Eu não tenho opinião própria não. Eu acredito nas duas. Nos dois lados.

P: Mas como você acredita nos dois lados?

R: Eu acredito que aconteceu o Big Bang...[...] Aconteceu o Big Bang. Os planetas... Expandiu o universo, aí conforme foi passando o tempo, o calor do Big Bang foi formando a Terra, aí a Terra... Começou a nascer a Terra, a vegetação, os animais começaram a aparecer... Aí tipo, os macacos, como nós somos descendentes dos macacos, posso afirmar isso, foram evoluindo e foi chegando a gente. Na outra parte, como na parte de Deus, eu posso falar o seguinte: Deus criou o universo, criou a Terra, levou sete dias para criar a Terra. Aí criou um ser humano e aí nessa parte do ser humano ele tirou uma costela do osso da pessoa e criou a mulher.

P: Qual dessas se aproxima mais da sua visão?

R: Mais na parte da ciência. Mais na parte da ciência, mesmo.

P: Por quê? Porque você acredita mais nessa visão da ciência do que na visão religiosa?

R: Porque, como todo o cientista fala, o Big Bang foi uma energia que acabou expandindo o universo e acabou criando os planetas. [...] Eu acabo acreditando na ciência porque, tipo, do jeito que eles falam é bem realista, bem mais real que a história de Deus. Eu acredito mais na ciência.

P: E por que é mais real?

R: Porque eles pesquisaram muito para acabar chegando nessa conclusão. Eu acabo
} acreditando nisso.

Vale a pena notar que o estudante, primeiramente, afirma que não acredita que nenhum dos dois lados está incorreto, o que aponta no sentido de uma conciliação de ambos. No entanto, quando o questionamos mais diretamente como 
ele conseguiria acreditar "nos dois lados", o estudante apenas expõe a forma como entende as teorias científicas e o conhecimento religioso, sem estabelecer conexões entre eles (como outros alunos faziam se referindo a Deus atuando através de processos que a ciência investiga). Depois que perguntamos uma terceira vez com qual se identificaria mais, o educando diz que seria com o pensamento científico, pois em sua opinião seria mais real. Ao perguntarmos por que achava mais real, A11 se remete à autoridade de cientistas e ao tempo por ele dedicado para estudar sobre os processos de origem e evolução da vida. Chama atenção, contudo, que este argumento também nos parece problemático, em certa medida, pois não leva em consideração o grande número de evidências empíricas e a lógica da pesquisa científica. Embora o aluno pareça aceitar a teoria evolutiva, seu entendimento ainda poderia ser mais aprofundado e baseado em mais reflexões.

É importante destacar, ainda, que o estudante demonstra certa semelhança com o grupo anterior já que expressa, até certo momento, aceitar tanto a visão científica quanto a religiosa, aproximando-se de uma ideia de raciocínio paralelo (EVANS; LEGARE; ROSENGREN, 2011). No entanto, optamos por consideralo distinto daqueles, pois, ao final de sua fala indica que estaria mais suscetível a aceitar a epistemologia científica, apontando no sentido de dois modelos culturais que competem entre si (ciência e sobrenatural), com predomínio da ciência.

Já A13 disse não acreditar em Deus, porém afirmou crer em reencarnação e em certa força da natureza. Essa força não seria uma agente criadora, mas sim, atuaria no sentido de fazer as pessoas serem recompensadas positiva ou negativamente pelas suas atitudes. Com relação à origem da vida, a estudante expressa uma visão mais próxima do pensamento científico:

P: Pensando mais nessa parte de origem da vida, como você explicaria a origem da vida no nosso planeta? Como surgiu a vida na Terra?

A13: Ué, pela evolução, né? Que nem a professora de biologia fala. Eu acredito nisso. Eu não acredito em Adão e Eva não. Até porque tem tantas etnias, tipo, asiático, negro, índio. E não tem como duas pessoas darem vida a tantas etnias, sendo que eles eram iguais. Então eu acredito nisso. Que as pessoas vão se evoluindo, se transformando, mutação também.

P: Mas o que você acha... Quando o professor fica falando que a vida pode surgir sem a interferência de Deus, numa força...

A13: Eu acredito. Porque é uma coisa mais fácil de acreditar.

P: Qual a relação que você vê entre a origem da vida, evolução e a força que você disse que você acredita?

A13: Não. Nada a ver. Eu acho que não. Essa força que eu estou falando é do ser humano, sabe? Não está na cabeça dos animais que estavam lá. Acho que não. Se teve uma força foi por causa do universo, sei lá. 
P: Pra surgir o universo, essa força... Como essa força teria atuado nisso?

A13: Não sei, a natureza, né? A força da natureza... Não sei explicar, mas acho que é isso.

P: A sua opinião mesmo... Como você pensa sobre isso?

A13: Sei lá... Foram tanto tempo... As coisinhas podem evoluir... Bactérias que vivem no mar, podem sair do mar..... Sei lá, eu tenho muita dúvida, sabe... Eu não tenho uma opinião completamente formada. [...] Um dia, eu vi um documentário sobre as sereias que existem, mas não do jeito que a gente pensa... Aí você vê que é tudo mentira... Nossa... Você não pode acreditar em tudo o que vê. Por isso que eu não acredito na Bíblia. Não pode acreditar em tudo o que lê.

A13 diz que acredita que a vida tenha surgido de acordo com as teorias científicas que estudou em suas aulas de biologia. Ela argumenta que não acredita em Adão e Eva porque não seria possível que diversas etnias fossem formadas a partir de dois indivíduos iguais. Na sequência, ela acrescenta que os seres humanos passam por processos evolutivos e também sofrem mutações. Quando questionada sobre a relação entre a força em que crê e a origem dos seres vivos, ela diz que não há uma conexão. A educanda explica que essa força seria inerente aos seres humanos e não a outros animais. Além disso, a força que seria responsável pela origem do universo e da vida seria uma "força da natureza", a qual não consegue definir com precisão. Ao pedirmos por mais detalhes, A13 disse não estar plenamente certa e se refere a um documentário que assistiu e cuja veracidade questionou. Acrescenta, ainda, que é por isso que não acredita na Bíblia, pois não se deve acreditar em tudo que lê.

A fala da estudante revela que ela aceita as teorias científicas para a origem e evolução da vida e que procura explicações empíricas para justificar sua opinião, como a diversidade de etnias dos seres humanos. Assim, não apenas assume a posição de cientistas como verdadeira, tal qual A11, mas demonstra certa reflexão própria para desenvolver sua visão. Em segundo lugar, há duas definições de "força" utilizadas. A primeira, restrita aos humanos, assemelhar-seia à motivação de uma pessoa para realizar algo, enquanto a segunda estaria relacionada à natureza como um todo, indicando certa intencionalidade sobre seus processos. Como apontado por Blancke et al.(2011) e Evans, Legare e Rosengren (2011), a teleologia é uma ideia intuitiva de humanos sobre os processos ao seu redor e que se apresenta como um obstáculo para a compreensão da teoria evolutiva neodarwinista. Nesse sentido, é importante destacar que mesmo uma estudante que aparenta aceitar as teorias científicas para a origem e evolução da vida apresenta ideias que podem limitar seu entendimento. 
A fim de explicitar e sintetizar as posições dos estudantes sobre a origem e a evolução da vida e, mais especificamente, dos seres humanos, elaboramos os dois gradientes da Figura 5.1. Nestes, quanto mais próximo ao lado esquerdo, mais literalista e mais resistente à teoria evolutiva, enquanto que o oposto se dá para quanto mais à direita está posicionado.

No gradiente superior, há cinco grupos distintos, os quais foram descritos acima. O primeiro, "Literal”, é o dos estudantes que aderem à uma visão próxima ao texto literal do Gênesis e é formado por A2 (católico), A10 (sem religião), A6, A7, A9, A12, A14, A16, A17, A18 e A19 (evangélicos). Para estes alunos, Deus criou a vida, Adão e Eva existiram e os dias da criação foram intervalos de 24 horas. O segundo, "Mescla", reúne os educandos que expressam dúvidas quanto a determinados trechos da Bíblia e aceitam determinados elementos científicos, embora o façam de forma confusa. Fazem parte desse grupo as estudantes A1, A3 e A20, evangélicas. O terceiro grupo, "Dia-Era", é formado apenas por um aluno, A15, evangélico. Ele acredita no relato Bíblico, mas os dias da criação seriam intervalos de milhões de anos, o que permitiria conciliar, em sua opinião, conciliar suas crenças religiosas com os conhecimentos científicos sobre a evolução dos seres vivos. O quarto grupo, "Evolucionismo Teísta", abrange os educandos A4, A8 (católicos) e A5 (ateu). Eles acreditam na teoria evolutiva neodarwinista, mas têm resistência em aceitar as explicações científicas para a origem do universo e da vida. Creem que um agente, Deus, no caso dos católicos, e uma Força, no caso do ateu, atuaram nesses processos. Por fim, o último conjunto, formado por A11 (católico) e A13 (sem religião), "Evolução", agrupa os estudantes que demonstram aceitar as teorias científicas. Cabe a ressalva, contudo, que o estudante A11 manifesta uma posição oscilante entre a visão religiosa e a científica.

No gradiente inferior, há sete grupos ordenados de acordo com a aceitação da teoria evolutiva neodarwinista para os seres humanos. Uma vez que a dispersão e a complexidade deste ponto são maiores do que a do anterior, o uso de categorias já utilizadas nos trabalhos citados ao longo deste texto, parece-nos não as captar satisfatoriamente. Assim, dividimos os estudantes entrevistados em sete grupos diferentes. 


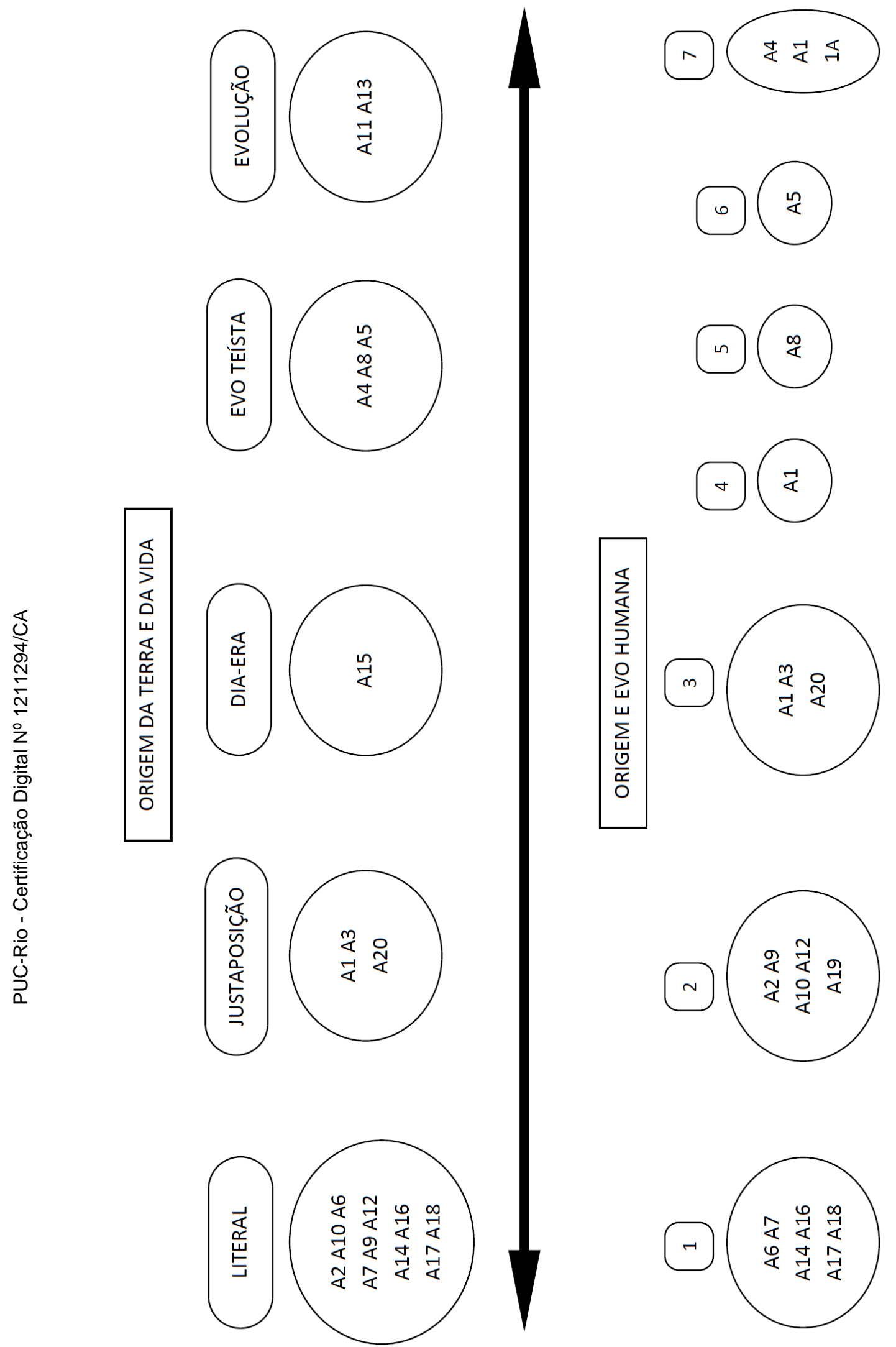

Figura 5.1: Estudantes entrevistados de acordo com o gradiente de concepções sobre origem da Terra, da vida e dos seres humanos. 
No primeiro conjunto, estão os educandos A6, A7, A14, A16, A17, A18. Estes são os que expressam maior rejeição à teoria evolutiva neodarwinista. Acreditam que Deus atuou diretamente na origem dos seres humanos, criando Adão a partir do barro e, de uma de suas costelas, Eva. Além disso, dizem que não acreditam na evolução porque esta diria que os humanos vieram dos macacos, o que não seria verdade, posto que ainda encontramos macacos atualmente e estes não estão se transformando naqueles.

O segundo grupo, formado pelos estudantes A2, A9, A10, A12 e A19, reúne as mesmas características do primeiro, exceto pela menção aos macacos. Já o terceiro conjunto envolve as estudantes A1, A3 e A20, que expressam uma visão que mistura determinados conceitos científicos com a crença de que Deus teve alguma participação na origem dos seres humanos. $\mathrm{O}$ quarto se restringe ao estudante A15, que acredita no criacionismo de dia-era e que a evolução humana é fruto da atividade de Deus, montando os seres humanos. O quinto é formado apenas por A8, o qual acredita nas teorias científicas para a evolução dos humanos, contudo também pensa que extraterrestres influenciaram nesse processo. O sexto, por sua vez, engloba A5 e A11, que aceitam a evolução humana, todavia demonstram certa incerteza. Por fim, o sétimo conjunto abarca A4 e A13, para quem o ser humano foi formado exclusivamente por processos naturais.

\section{2}

\section{Análise quantitativa dos questionários aplicados aos estudantes}

Nesta seção, analisamos os dados obtidos através do questionário (Apêndice 1) aplicado a todas as turmas de $1^{\circ}$ ano do ensino médio participantes da pesquisa, conforme detalhado nos capítulos 1 e 3 . Em um primeiro momento analisaremos as questões relacionadas à aceitação da teoria evolutiva neodarwinista, em um segundo momento a religiosidade baseada no índice DUREL. Por fim, fazemos correlações entre os índices criados, variáveis demográficas e outras de interesse da pesquisa. 


\section{2 .1}

\section{Aceitação da teoria evolutiva neodarwinista}

Como discutimos anteriormente, para buscar medir a aceitação da teoria evolutiva neodarwinista, fizemos uma livre-adaptação do MATE (RUTLEDGE; WARDEN, 1999), formando as 12 frases contidas na tabela ao início do questionário. Os construtos que essas variáveis procuraram medir estão descritos no Quadro 5.1 abaixo. O MATE originalmente também incluía um sexto construto, "Visão da comunidade científica sobre a evolução", o qual optamos por excluir já que acreditamos - e confirmamos em nossas observações - que os estudantes não teriam conhecimento o suficiente sobre essa dimensão. As tabelas 5.1 e 5.2mostramas frequências das respostas para cada uma das frases para o Colégio Guarani e Passaredo, respectivamente.

\begin{tabular}{|l|l|}
\hline Construto & Item \\
\hline Processos evolutivos & $1,2,9,10$ \\
\hline Validade científica da teoria evolutiva neodarwinista & $3,4,8,11$ \\
\hline Evolução humana & 6,7 \\
\hline Evidências da evolução & 5 \\
\hline Idade da Terra & 12 \\
\hline
\end{tabular}

Quadro 5.1: Construtos medidos pelos itens do questionário aplicado aos estudantes. 


\begin{tabular}{|c|c|c|c|c|c|c|}
\hline & 1 & 2 & 3 & 4 & 5 & Média \\
\hline $\begin{array}{l}\text { 1. Os organismos atuais são resultado de } \\
\text { processos evolutivos que ocorreram ao longo } \\
\text { de milhões de anos. }\end{array}$ & 13,3 & 7,3 & 23,6 & 22,3 & 33,1 & 3,55 \\
\hline $\begin{array}{l}\text { 2. Os organismos atuais têm basicamente as } \\
\text { mesmas formas que sempre tiveram. }\end{array}$ & 39,3 & 21,1 & 21,6 & 9,8 & 8,0 & 2,26 \\
\hline $\begin{array}{l}\text { 3. A teoria da evolução não é capaz de ser } \\
\text { testada cientificamente. }\end{array}$ & 32,8 & 18,0 & 18,5 & 17,0 & 12,5 & 2,58 \\
\hline $\begin{array}{l}\text { 4. A evolução é uma teoria cientificamente } \\
\text { válida. }\end{array}$ & 11,8 & 9,8 & 21,1 & 21,1 & 35,1 & 3,59 \\
\hline $\begin{array}{l}\text { 5. Há muitos dados que apoiam a teoria da } \\
\text { evolução. }\end{array}$ & 8,5 & 10,3 & 26,6 & 22,3 & 30,6 & 3,57 \\
\hline $\begin{array}{l}\text { 6. Os humanos atuais são resultado de } \\
\text { processos evolutivos que ocorreram ao longo } \\
\text { de milhões de anos. }\end{array}$ & 15,8 & 6,5 & 14,5 & 19,5 & 42,6 & 3,67 \\
\hline $\begin{array}{l}\text { 7. Os humanos têm as mesmas formas que } \\
\text { sempre tiveram. }\end{array}$ & 53,6 & 12,5 & 9,8 & 7,3 & 14,3 & 2,14 \\
\hline $\begin{array}{l}\text { 8. A Bíblia oferece a melhor explicação sobre } \\
\text { as características e comportamentos dos } \\
\text { seres vivos. }\end{array}$ & 22,3 & 15,3 & 23,3 & 13,8 & 24,8 & 3,04 \\
\hline $\begin{array}{l}\text { 9. A teoria da evolução oferece a melhor } \\
\text { explicação sobre as características e } \\
\text { comportamentos dos seres vivos. }\end{array}$ & 15,8 & 12,0 & 30,6 & 20,1 & 20,6 & 3,18 \\
\hline $\begin{array}{l}\text { 10. Com poucas exceções, os seres vivos } \\
\text { surgiram mais ou menos ao mesmo tempo. }\end{array}$ & 31,1 & 23,3 & 26,8 & 10,8 & 6,8 & 2,38 \\
\hline $\begin{array}{l}\text { 11. A teoria da evolução não pode estar } \\
\text { correta, pois é diferente do que a Bíblia diz } \\
\text { sobre a criação. }\end{array}$ & 29,3 & 15,0 & 24,8 & 11,8 & 18,5 & 2,75 \\
\hline $\begin{array}{l}\text { 12. O planeta Terra tem pelo menos } 4 \text { bilhões } \\
\text { de anos. }\end{array}$ & 12,5 & 5,8 & 23,8 & 18,8 & 38,1 & 3,65 \\
\hline
\end{tabular}

Tabela 5.1: Frequência (\%)e média das respostas relacionadas à aceitação da teoria evolutiva neodarwinista pelos alunos do Colégio Guarani $(n=399)$. A escala vai de 1 (não acredito) até 5 (acredito fortemente). 


\begin{tabular}{|c|c|c|c|c|c|c|}
\hline & 1 & 2 & 3 & 4 & 5 & Média \\
\hline $\begin{array}{l}\text { 1. Os organismos atuais são resultado } \\
\text { de processos evolutivos que ocorreram } \\
\text { ao longo de milhões de anos. }\end{array}$ & 13,4 & 8,5 & 23,9 & 18,3 & 35,9 & 3,55 \\
\hline $\begin{array}{l}\text { 2. Os organismos atuais têm } \\
\text { basicamente as mesmas formas que } \\
\text { sempre tiveram. }\end{array}$ & 24,6 & 26,1 & 15,5 & 14,1 & 19,7 & 2,78 \\
\hline $\begin{array}{l}\text { 3. A teoria da evolução não é capaz de } \\
\text { ser testada cientificamente. }\end{array}$ & 31,7 & 14,1 & 23,9 & 11,3 & 19,0 & 2,72 \\
\hline $\begin{array}{l}\text { 4. A evolução é uma teoria } \\
\text { cientificamente válida. }\end{array}$ & 13,4 & 12,0 & 23,9 & 16,2 & 33,1 & 3,44 \\
\hline $\begin{array}{l}\text { 5. Há muitos dados que apoiam a teoria } \\
\text { da evolução. }\end{array}$ & 12,7 & 13,4 & 23,9 & 18,3 & 28,2 & 3,37 \\
\hline $\begin{array}{l}\text { 6. Os humanos atuais são resultado de } \\
\text { processos evolutivos que ocorreram ao } \\
\text { longo de milhões de anos. }\end{array}$ & 14,8 & 13,4 & 12,7 & 14,8 & 41,5 & 3,57 \\
\hline $\begin{array}{l}\text { 7. Os humanos têm as mesmas formas } \\
\text { que sempre tiveram. }\end{array}$ & 40,8 & 13,4 & 9,9 & 12,7 & 21,1 & 2,59 \\
\hline $\begin{array}{l}\text { 8. A Bíblia oferece a melhor explicação } \\
\text { sobre as características e } \\
\text { comportamentos dos seres vivos. }\end{array}$ & 20,4 & 9,9 & 19,7 & 9,9 & 38,7 & 3,37 \\
\hline $\begin{array}{l}\text { 9. A teoria da evolução oferece a melhor } \\
\text { explicação sobre as características e } \\
\text { comportamentos dos seres vivos. }\end{array}$ & 19,0 & 12,7 & 23,9 & 19,0 & 25,4 & 3,19 \\
\hline $\begin{array}{l}\text { 10. Com poucas exceções, os seres } \\
\text { vivos surgiram mais ou menos ao } \\
\text { mesmo tempo. }\end{array}$ & 20,4 & 21,8 & 28,2 & 13,4 & 14,8 & 2,80 \\
\hline $\begin{array}{l}\text { 11. A teoria da evolução não pode estar } \\
\text { correta, pois é diferente do que a Bíblia } \\
\text { diz sobre a criação. }\end{array}$ & 22,5 & 7,0 & 21,8 & 14,1 & 33,1 & 3,29 \\
\hline $\begin{array}{l}\text { 12. O planeta Terra tem pelo menos } 4 \\
\text { bilhões de anos. }\end{array}$ & 14,8 & 13,4 & 21,8 & 15,5 & 34,5 & 3,42 \\
\hline
\end{tabular}

Tabela 5.2: Frequência (\%) das respostas relacionadas à aceitação da teoria evolutiva neodarwinista pelos alunos do Colégio Passaredo $(n=142)$. A escala vai de 1 (não acredito) até 5 (acredito fortemente).

A fim de avaliar se a diferença entre o padrão de respostas para as duas escolas é estatisticamente significativa, utilizamos o teste U de Mann-Whitney ${ }^{46}$. As diferenças foram significativas para as questões 2, 7, 8, 10 e 11. Para a questão 2 , os estudantes do Colégio Guarani (Mediana $=2,00)^{47}$ aceitam menos do que os do Colégio Passaredo (Mediana $=2,00$ ) a ideia de que os organismos atuais têm

\footnotetext{
${ }^{46} \mathrm{O}$ teste U de Mann-Whitney é o mais adequado para comparar duas amostras independentes para dados não-paramétricos. De acordo com Field (2009), os testes não-paramétricos devem ser usados quando os dados não satisfazem as hipóteses dos testes paramétricos, principalmente que os dados não são normalmente distribuídos. Em nosso caso, o teste de normalidade de Kolmogorov-Smirnov indicou $\mathrm{p}<0,001$, evidenciando que os dados não distribuídos normalmente. O objetivo do teste $\mathrm{U}$ de Mann-Whitney é verificar se duas amostras independentes são significativamente diferentes. Assim, usa-se uma hipótese nula $\left(\mathrm{H}_{0}\right)$ de que as amostras não são significativamente diferentes e testa-se a Hipótese Alternativa $\left(\mathrm{H}_{1}\right)$ de que as amostras são estatisticamente significativas.

${ }^{47}$ Seguimos as sugestões de Field (2009) para reportar os resultados dos testes utilizados, ou seja, indicamos a mediana de cada grupo, o valor de $\mathrm{U}$, o p-valor e o efeito (r).
} 
as mesmas formas que sempre tiveram, $U=22531,50, p<0,001, r=-0,16$. Para a questão 7 , os alunos do Colégio Guarani (Mediana $=1,00)$ tendem a aceitar menos do que os do Colégio Passaredo (Mediana $=2,00$ ) a ideia de que os humanos têm as mesmas formas que sempre tiveram, $U=22825,00, p<0,05, r=$ -0,13).Para a questão 8, os estudantes do Colégio Guarani (Mediana $=3,00$ ) tendem a aceitar menos do que os do Colégio Passaredo (Mediana $=4,00)$ a ideia de que a Bíblia oferece a melhor explicação sobre as características e comportamentos dos seres vivos, $\mathrm{U}=24215,00, \mathrm{p}<0,05, \mathrm{r}=-0,10$. Quanto à questão 10, os estudantes do Colégio Guarani (Mediana $=2,00)$ tendem a aceitar menos do que os estudantes do Colégio Passaredo (Mediana $=3,00$ ) que os seres vivos, com poucas exceções, surgiram mais ou menos ao mesmo tempo, $\mathrm{U}=$ 22306,5,p < 0,05, $\mathrm{r}=-0,14$.Já para a questão 11, os alunos do Colégio Guarani (Mediana $=3,00)$ tendem a aceitar menos do que os do Colégio Passaredo (Mediana $=3,00)$ a ideia de que a teoria da evolução não pode estar correta, pois é diferente do que a Bíblia diz sobre a criação, $U=22306,5, p<0,001, r=-0,15$. Esses dados indicam que os(as) estudantes do Colégio Guarani tendem a expressar maior aceitação à teoria evolutiva do que os(as) do Colégio Passaredo para essas afirmações, mas o efeito é pequeno $(r<0,3)$, de acordo com Field (2009). Como o resultado do teste não foi significativo para as outras questões, podemos afirmar que a diferença entre as duas escolas não foi estatisticamente significativa para as outras afirmativas.

$\mathrm{Na}$ tentativa de criarmos um índice de aceitação da evolução, fizemos a análise fatorial exploratória com as doze variáveis acima indicadas. Atribuímos escores de 1 a 5, de acordo com a marcação do respondente. As questões 2, 3, 7, 8,10 e 11 tiveram seus escores invertidos, já que quanto mais um aluno expressava acreditar nelas, menos ele acreditava na teoria evolutiva. A tabela 5.3 mostra os fatores obtidos e as cargas fatoriais de cada variável: 


\section{Rotated Component Matrix}

\begin{tabular}{ccc}
\multicolumn{3}{c}{ Fator } \\
\hline $\mathbf{1}$ & $\mathbf{2}$ & $\mathbf{3}$ \\
0,590 & & \\
& & 0,625 \\
& & 0,442
\end{tabular}

1. Os organismos atuais são resultado de processos evolutivos que ocorreram ao longo de milhões de anos.

2. Os organismos atuais têm basicamente as mesmas formas que sempre tiveram.

3. A teoria da evolução não é capaz de ser testada cientificamente.

4. A evolução é uma teoria cientificamente válida. $\quad 0,681$

5. Há muitos dados que apoiam a teoria da evolução.

0,593

6. Os humanos atuais são resultado de processos evolutivos que ocorreram ao longo de milhões de anos.

0,654

7. Os humanos têm as mesmas formas que sempre tiveram.

$0,326 \quad 0,507$

8. A Bíblia oferece a melhor explicação sobre as $\quad 0,827$ características e comportamentos dos seres vivos.

9. A teoria da evolução oferece a melhor explicação sobre as características e comportamentos dos seres vivos.

10. Com poucas exceções, os seres vivos surgiram mais ou menos ao mesmo tempo.

11. A teoria da evolução não pode estar correta, pois é diferente do que a Bíblia diz sobre a criação.

12. O planeta Terra tem pelo menos 4 bilhões de anos. $\quad 0,512$

Extraction Method: Principal Component Analysis. Rotation Method: Varimax with Kaiser Normatization Variância explicada: $47,94 \%$ $\mathrm{KMO}^{48}=0,805$

Alfa de Cronbach $=\mathbf{0 , 7 4 7}$

Tabela 5.3: Análise fatorial para os itens de aceitação da teoria evolutiva neodarwinista. Apenas as cargas superiores a 0,30 são mostradas.

O MATE foi pensado originalmente para fornecer um índice unifatorial para a aceitação da evolução(RUTLEDGE; WARDEN, 1999). Como apontado por Wagler e Wagler (2013), o MATE foi elaborado para pesquisar professores de biologia, em exercício, no ensino médio, não-hispânicos, nos EUA. Eles criticam que muitas outras pesquisas fizeram uso dessas questões, na íntegra ou modificadas, para grupos diferentes do original, tratando-o como um índice

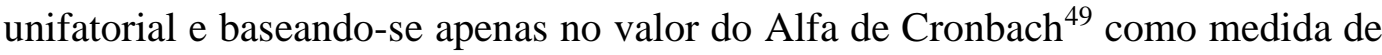
validade. Os autores conduziram eles próprios a aplicação do MATE, na íntegra,

\footnotetext{
${ }^{48} \mathrm{KMO}$ (Kaiser-Meyer-Olkim) indica a adequação da amostra. O seu valor varia de 0 a 1 . Field (2009) indica que valores acima de 0,5 são aceitáveis, entre 0,5 e 0,7 são medíocres, entre 0,7 e 0,8 são bons, entre 0,8 e 0,9 são ótimos e acima de 0,9 são excelentes.

${ }^{49} \mathrm{O}$ alfa de Cronbach é uma medida de confiabilidade de uma escala. Seu valor varia de 0 a 1 , sendo os valores entre 0,7 e 0,8 considerados aceitáveis. Valores muito abaixo desses indicam uma escala não confiável(FIELD, 2009).
} 
para licenciandos hispânicos de educação primária e verificaram a existência de seis fatores. Além disso, os autores apontam que itens que contém afirmações opostas não possuem alta correlação entre si quando os escores são revertidos.

Assim como Wagler e Wagler (2013), a amostra de nossa pesquisa é distinta da original do MATE e não encontramos um único fator. Observamos três fatores: o primeiro envolvendo as afirmações escritas positivamente (isto é, aquelas cuja concordância implica na aceitação da teoria evolutiva), o segundo envolvendo as afirmações que envolvem a Bíblia e o terceiro com as afirmações escritas negativamente. A exceção se dá pela questão 7, que está ligada, ao mesmo tempo, aos fatores 1 e 3 . Assim, excluímos as questões 2, 3, e 10, porque o fato de não estarem alinhadas com as afirmações positivas acerca da teoria evolutiva indica que provavelmente os estudantes não compreenderam o comando da questão. Excluímos, também, a questão 7, por se alinhar a dois fatores diferentes. Refizemos a análise fatorial sem as questões apontadas e obtivemos os seguintes fatores e cargas (Tabela 5.4):

\section{Rotated Component Matrix ${ }^{\mathrm{a}}$}

Component

1. Os organismos atuais são resultado de processos evolutivos que ocorreram ao longo de milhões de anos.

12

4. A evolução é uma teoria cientificamente válida. 0,654

5. Há muitos dados que apoiam a teoria da evolução. 0,688

6. Os humanos atuais são resultado de processos evolutivos que ocorreram ao longo de milhões de anos.

0,643

8. A Bíblia oferece a melhor explicação sobre as características e comportamentos dos seres vivos.

9. A teoria da evolução oferece a melhor explicação sobre as características e comportamentos dos seres vivos.

$0,523 \quad 0,313$

11. A teoria da evolução não pode estar correta, pois é diferente do que a Bíblia diz sobre a criação.

12. O planeta Terra tem pelo menos 4 bilhões de anos.

Extraction Method: Principal Component Analysis. Rotation Method: Varimax with Kaiser Normalization. Variância explicada $=49,87 \%$ $\mathrm{KMO}=0,773$

Alfa de Cronbach $=0,713$ a. Rotation converged in $\mathbf{3}$ iterations.

Tabela 5.4: Análise fatorial para os itens de aceitação da teoria evolutiva neodarwinista. Apenas as cargas superiores a 0,30 são mostradas. 
Após essa nova análise, dois fatores foram carregados. A questão 9 foi a única que se ligou a ambos, o que nos faz acreditar que não esteja plenamente adequada ao nosso objetivo. Optamos por retirá-la e realizar uma nova análise fatorial com as variáveis restantes. Dessa maneira, obtivemos os fatores e cargas da Tabela 5.5 abaixo:

\section{Rotated Component Matrix}

Component

1. Os organismos atuais são resultado de processos evolutivos que ocorreram ao longo de milhões de anos.

12

4. A evolução é uma teoria cientificamente válida.

5. Há muitos dados que apoiam a teoria da evolução.

0,649

6. Os humanos atuais são resultado de processos evolutivos que ocorreram ao longo de milhões de anos.

8. A Bíblia oferece a melhor explicação sobre as características e comportamentos dos seres vivos.

0,834

11. A teoria da evolução não pode estar correta, pois é diferente do que a Bíblia diz sobre a criação.

12. O planeta Terra tem pelo menos 4 bilhões de anos.

0,532

Extraction Method: Principal Component Analysis. Rotation Method: Varimax with Kaiser Normalization. Variância explicada $=53,11 \%$ $\mathrm{KMO}=0,739$

Alfa de Cronbach $=0,678$

a. Rotation converged in $\mathbf{3}$ iterations.

Tabela 5.5: Análise fatorial para os itens de aceitação da teoria evolutiva neodarwinista. Apenas as cargas superiores a 0,30 são mostradas.

Dessa maneira, construímos o índice de aceitação da teoria evolutiva neodarwinista com base nessas sete variáveis e composto por dois fatores, para os quais criamos duas novas variáveis. O primeiro fator é composto pelas questões 1, 4, 5, 6 e 12 e reflete a Aceitação dos Aspectos Científicos da Teoria Evolutiva Neodarwinista (AC). Para este fator, quanto mais alto o escore do aluno, maior a aceitação da teoria evolutiva. Já o segundo fator é composto pelas questões 8 e 11 e indica a Aceitação da Narrativa Bíblica para a Origem e Evolução dos Seres Vivos (NB). Para este fator, quanto maior escore, menor a aceitação da teoria evolutiva. Os Gráficos 5.1 e 5.2 indicam as frequências destes fatores para todos os participantes da pesquisa. Os dados indicam que a maior parte dos estudantes 
tende a aceitar os aspectos científicos da teoria evolutiva (Mediana $=0,13$ ) e a rejeitar a narrativa bíblica (Mediana $=-0,03$ ). No entanto, para o segundo fator, como o Gráfico 5.2 mostra, as frequências são menos assimétricas - isto é, as barras estão mais "achatadas" - do que para o primeiro, o que denota que quantidades semelhantes de estudantes possuem o mesmo escore.

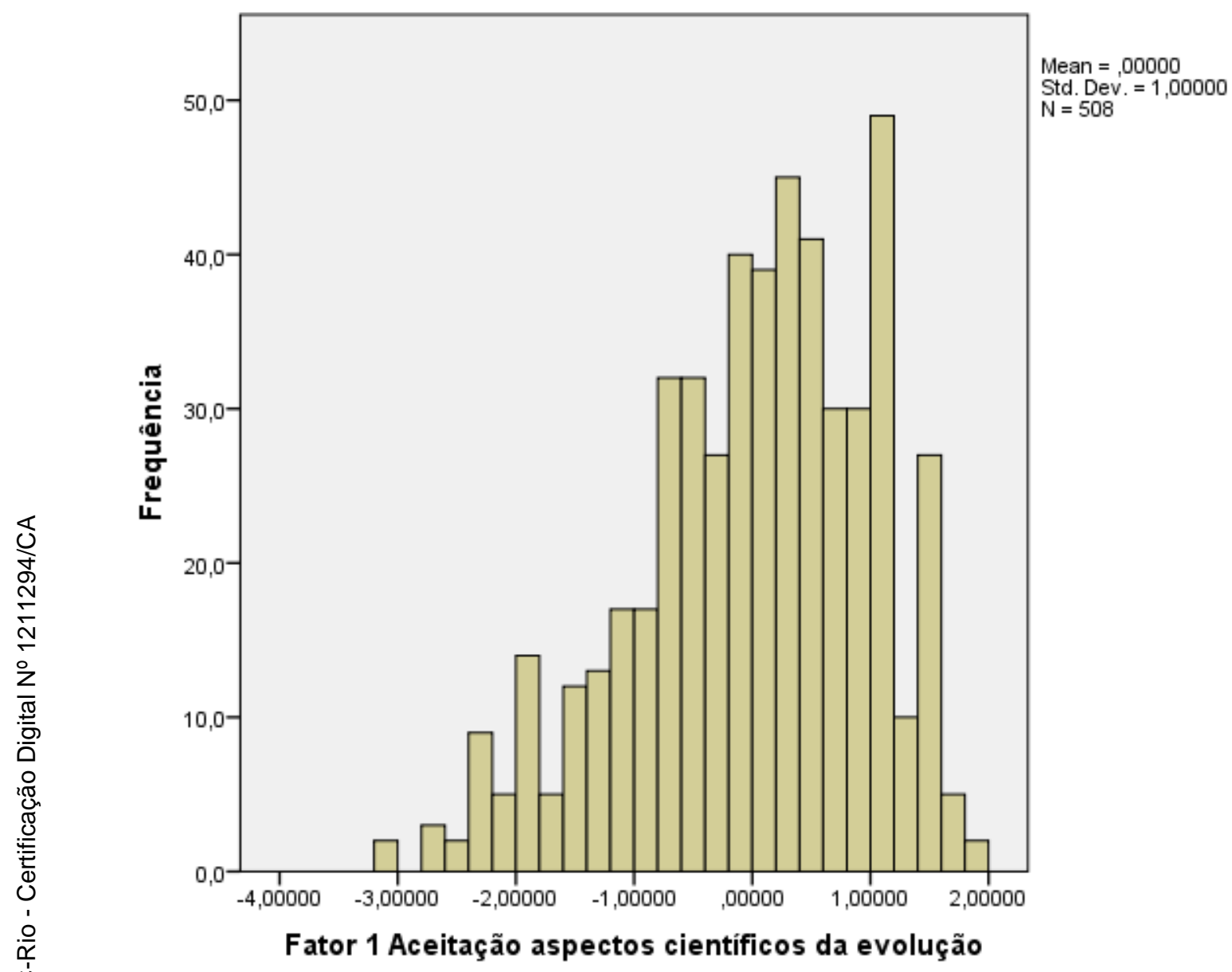

Gráfico 5.1: Frequências do Fator de Aceitação dos Aspectos Científicos da Teoria Evolutiva (AC) para os estudantes de ambos os colégios. Mediana $=0,13$. 


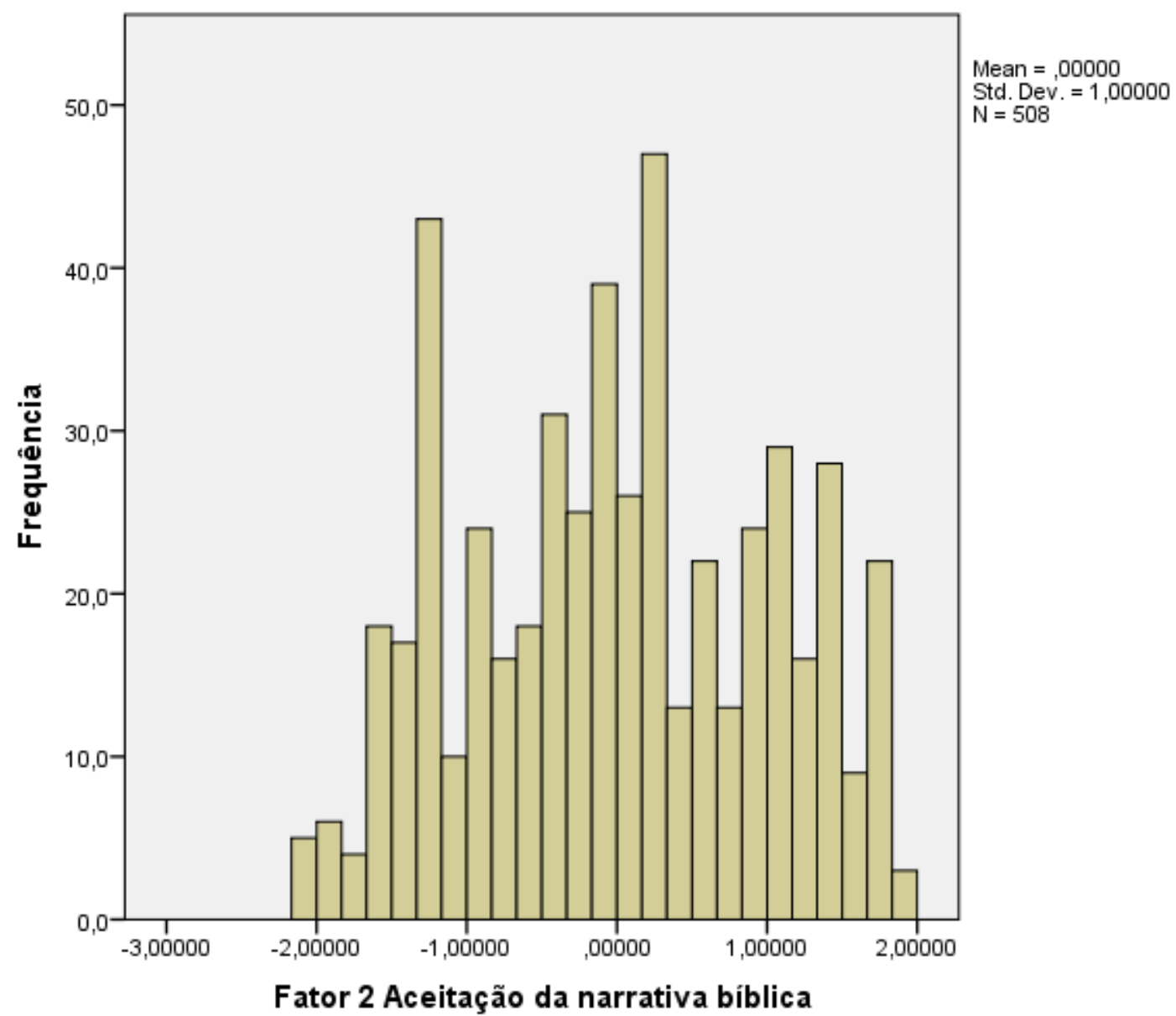

Gráfico 5.2: Frequências do Fator de Aceitação da Narrativa Bíblica para a Origem e Evolução dos Seres Vivos (NB) para os estudantes de ambos os colégios.

Ao realizarmos o teste U de Mann-Whitney comparando as duas escolas, encontramos que a diferença é significativa apenas para o fator NB. Os estudantes do Colégio Guarani (Mediana $=-0,10$ ) parecem diferir dos estudantes do Colégio Passaredo (Mediana = 0,27), $\mathrm{U}=20468,00, \mathrm{p}<0,05, \mathrm{r}=-0,12$, o que indica que os estudantes do primeiro tendem a aceitar menos a narrativa da Bíblia do que os do segundo, porém com um efeito pequeno ( $\mathrm{r}<0,3$ ). Os gráficos 5.3, 5.4, 5.5 e 5.6 mostram as frequências para os dois colégios. 


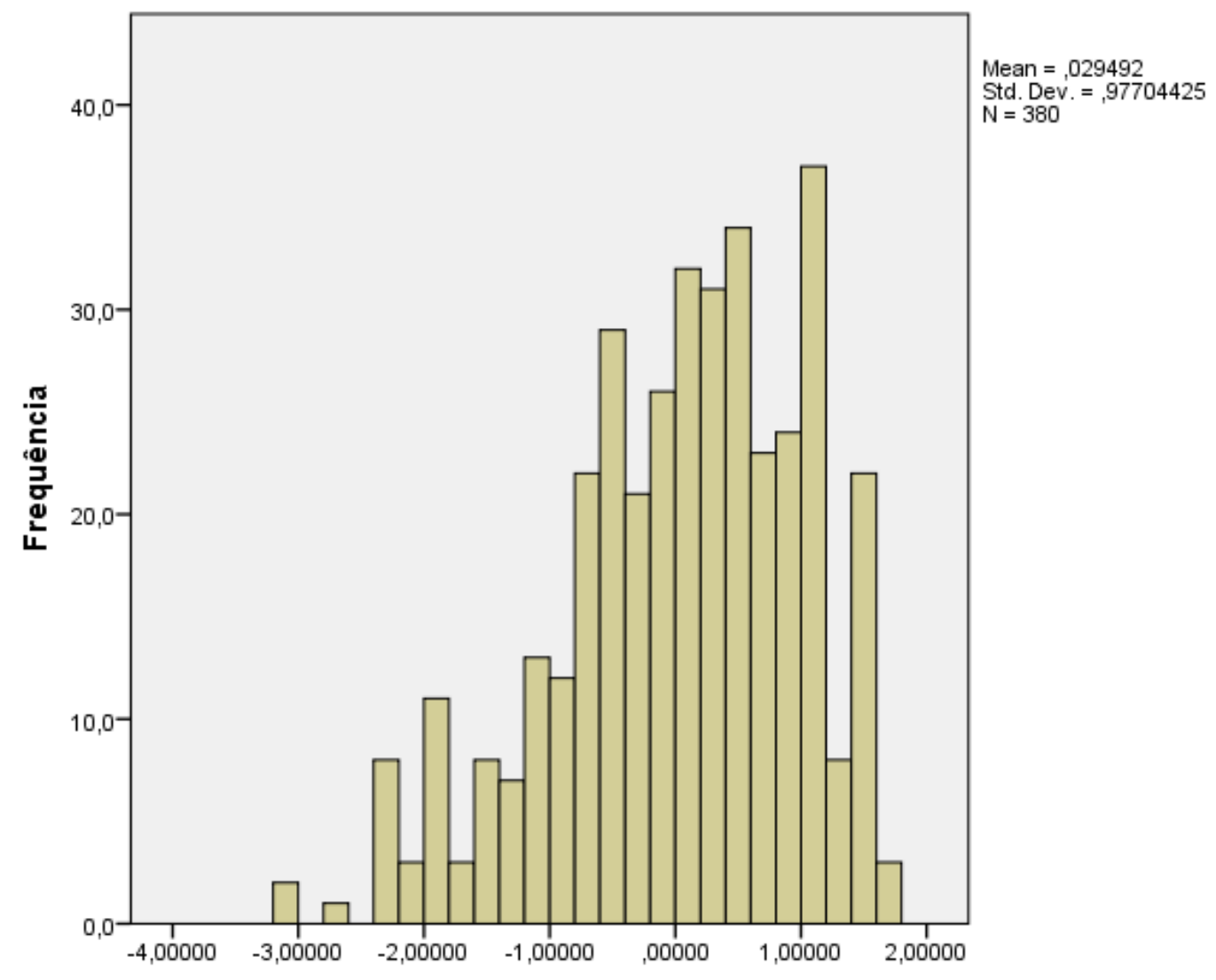

Fator 1 Aceitação aspectos científicos da evolução

Gráfico 5.3: Frequências do Fator AC para os estudantes do Colégio Guarani.

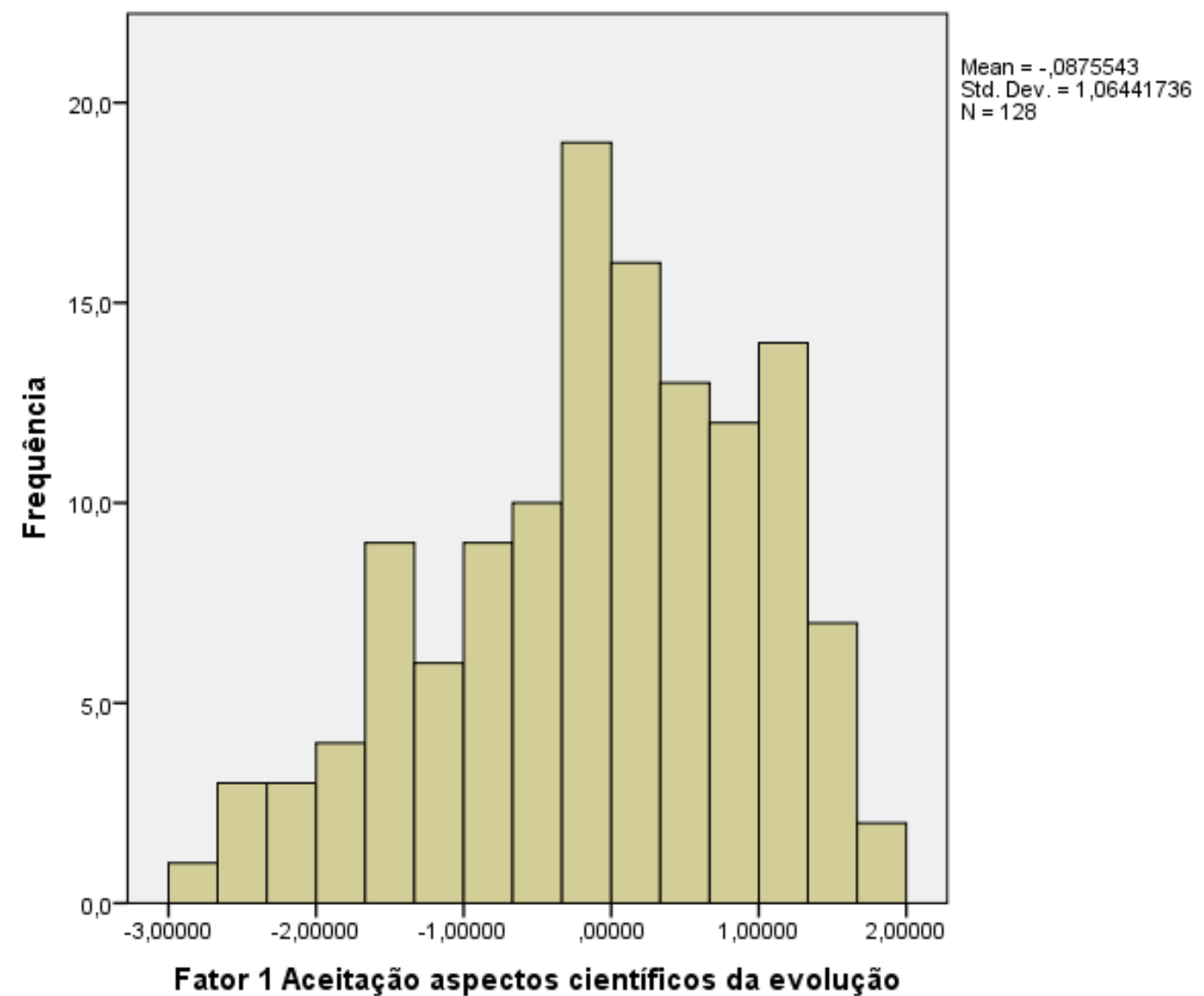

Gráfico 5.4: Frequências do Fator AC para os estudantes do Colégio Passaredo. 


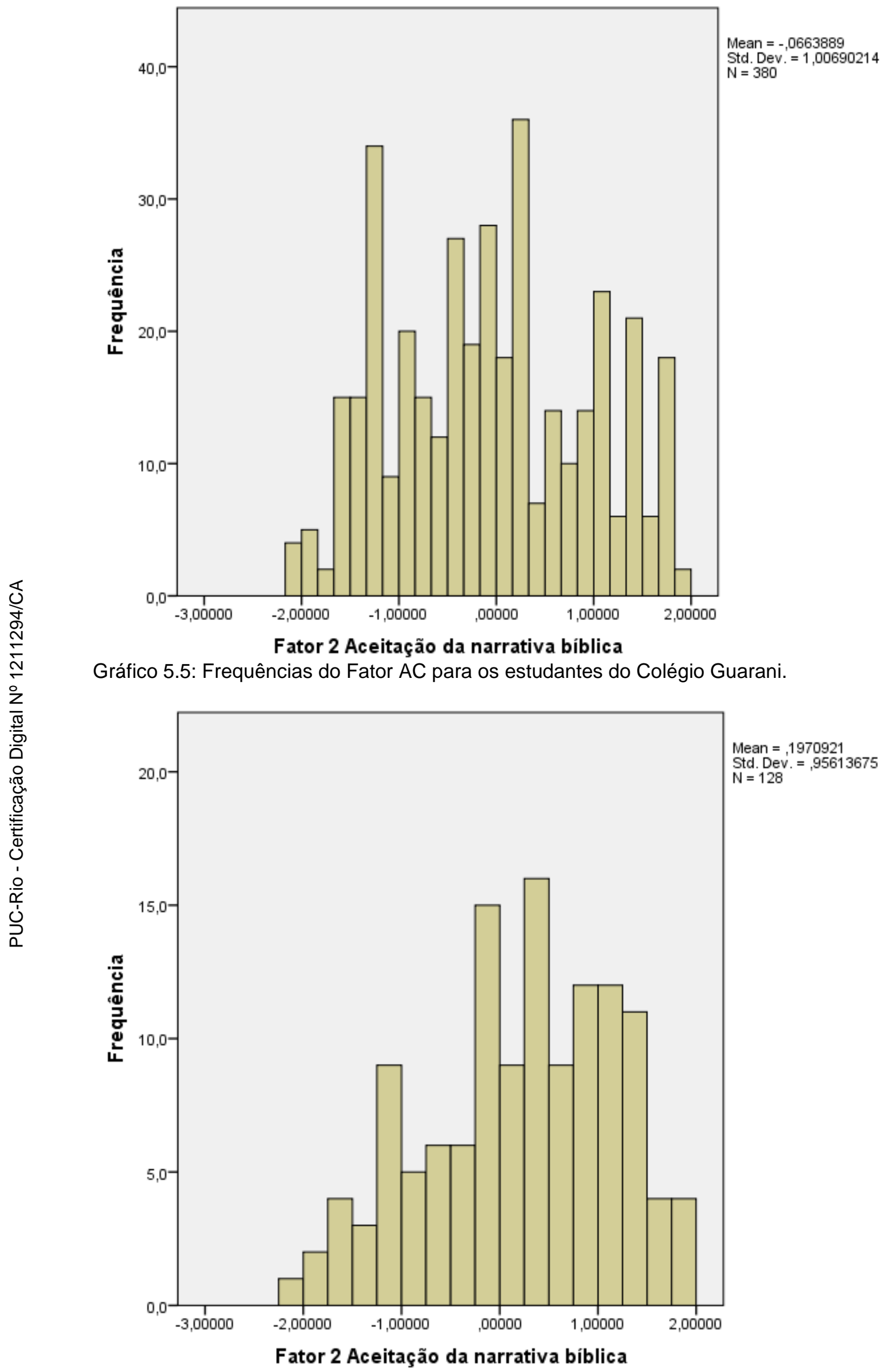

Gráfico 5.6: Frequências do Fator NB para os estudantes do Colégio Passaredo. 
Quando comparamos os fatores entre os diferentes grupos de religião ${ }^{50}$ através do teste $\mathrm{H}$ de Kruskal-Wallis ${ }^{51}$ (Tabela 5.6, Figura 5.2 e Figura 5.3), encontramos também diferenças significativas entre eles para o fator AC $(\mathrm{H}$ $(4)=10,464, \mathrm{p}<0,05)$ e o NB $(\mathrm{H}(4)=83,431, \mathrm{p}<0,001)$. De acordo com Field (2009) o teste $\mathrm{H}$ de Kruskal-Wallis requer testes post-hoc para verificar quais diferenças são, de fato, significativas, isto é, são necessários testes que verifiquem se o resultado do teste de Kruskal-Wallis é válido. Para evitar um aumento na possibilidade de cometer erros do tipo I (quando acredita-se que haja um efeito genuíno na população quando, na verdade, não há), o SPSS utiliza a significância corrigida pelo método Dunn-Bonferroni ${ }^{52}$ (IBM, 2014).

${ }^{50} \mathrm{~A}$ fim de facilitar a compreensão da análise, os grupos de religião que tinham poucos participantes (Candomblé, Espíritas Kardecistas, Testemunhas de Jeová e Umbandistas) foram agrupados na categoria "Outros".

${ }^{51}$ Seu funcionamento é semelhante ao teste de Mann Whitney, mas enquanto este compara apenas dois grupos, o de Kruskal-Wallis compara vários ao mesmo tempo. Seu objetivo é verificar se essas amostras são significativamente diferentes. Nesse momento de nosso texto, por exemplo, as amostras correspondem aos estudantes dos diferentes grupos de religião. Elas podem ser consideradas amostras independentes, porque a escolha da religião de um aluno não influencia a escolha da religião de outro.

${ }^{52}$ Field (2009) afirma que a maneira mais direta de se verificar os resultados de um teste KruskalWallis seria fazer vários testes de Mann-Whitney para cada par de grupos estudados. No entanto, isso faz com que a taxa de erros do tipo I fique inflacionada, correndo-se o risco de rejeitar a hipótese nula incorretamente. Assim, são necessárias correções sobre o valor de p a ser usado como referência, evitando-se cometer esses erros. 


\begin{tabular}{|c|c|c|c|}
\hline \multicolumn{2}{|l|}{ Religião } & \multirow{2}{*}{$\begin{array}{l}\text { Fator AC } \\
0,0364897\end{array}$} & \multirow{2}{*}{$\begin{array}{c}\text { Fator NB } \\
-0,2366984\end{array}$} \\
\hline \multirow{4}{*}{ Acredito em Deus, mas não tenho religião } & Média & & \\
\hline & $\mathrm{N}$ & 139 & 139 \\
\hline & Desvio padrão & 0,98595771 & 0,91625081 \\
\hline & Mediana & 0,0757006 & $-0,2236221$ \\
\hline \multirow{4}{*}{ Ateu } & Média & 0,4293998 & $-1,1215666$ \\
\hline & $\mathrm{N}$ & 17 & 17 \\
\hline & Desvio padrão & 0,96019032 & 0,73041438 \\
\hline & Mediana & 0,4948340 & $-1,3030119$ \\
\hline \multirow{4}{*}{ Católico } & Média & 0,0764874 & $-0,2178515$ \\
\hline & $\mathrm{N}$ & 156 & 156 \\
\hline & Desvio padrão & 0,88601784 & 0,89343033 \\
\hline & Mediana & 0,2183664 & $-0,1740281$ \\
\hline \multirow{4}{*}{ Evangélico } & Média & $-0,1946632$ & 0,5565665 \\
\hline & $\mathrm{N}$ & 154 & 154 \\
\hline & Desvio padrão & 1,04660505 & 0,91131452 \\
\hline & Mediana & $-0,0520969$ & 0,7419008 \\
\hline \multirow{4}{*}{ Outro } & Média & 0,1161775 & 0,0079581 \\
\hline & $\mathrm{N}$ & 39 & 39 \\
\hline & Desvio padrão & 1,22468301 & 1,08182515 \\
\hline & Mediana & 0,3941940 & $-0,0785989$ \\
\hline \multirow{4}{*}{ Total } & Média & $-0,0022640$ & 0,0001367 \\
\hline & $\mathrm{N}$ & 505 & 505 \\
\hline & Desvio padrão & 1,00174617 & 0,99993448 \\
\hline & Mediana & 0,1348209 & $-0,0062160$ \\
\hline
\end{tabular}

Tabela 5.6: Média, N, desvio padrão e mediana dos fatores AC e NB dos diferentes grupos religiosos. $\mathrm{O} N$ total difere do total de participantes da pesquisa, pois alguns respondentes deixaram questões em branco e foram excluídos do cálculo do índice. 
Independent-Samples Kruskal-Wallis Test

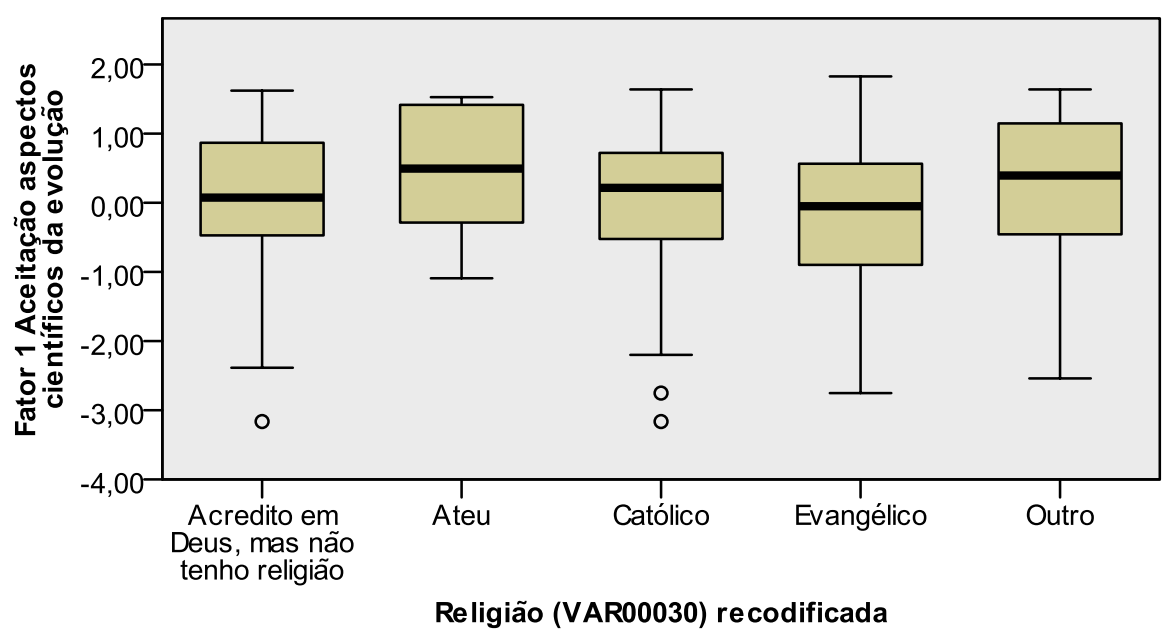

\begin{tabular}{|lr|}
\hline Total N & 505 \\
\hline Test Statistic & 10,464 \\
\hline Degrees of Freedom & 4 \\
\hline Asymptotic Sig. (2-sided test) &, 033 \\
\hline
\end{tabular}

1. The test statistic is adjusted for ties.

Figura 5.2: Teste $\mathrm{H}$ de Kruskal-Wallis do fator AC para os grupos de religião. 


\section{Independent-Samples Kruskal-Wallis Test}

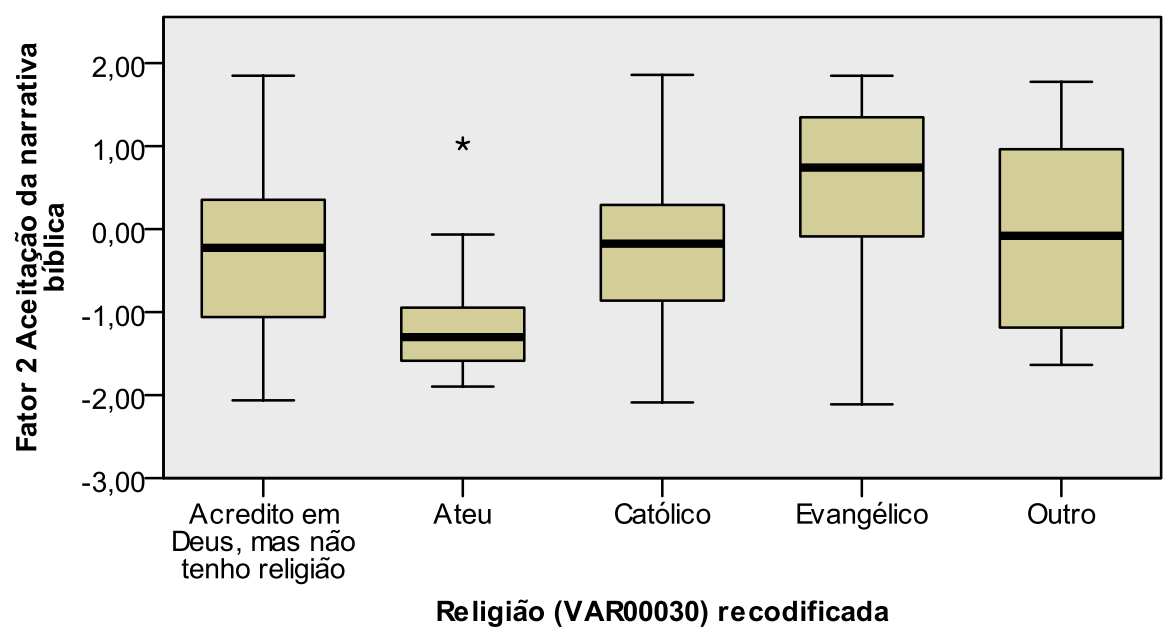

\begin{tabular}{|lr|}
\hline Total N & 505 \\
\hline Test Statistic & 83,431 \\
\hline Degrees of Freedom & 4 \\
\hline Asymptotic Sig. (2-sided test) &, 000 \\
\hline
\end{tabular}

1. The test statistic is adjusted for ties.

Figura 5.3: Teste $\mathrm{H}$ de Kruskal-Wallis do fator NB para os grupos de religião.

As diferenças para o fator AC revelaram-se não significativas para todos os casos, o que indica que não há diferença estatisticamente significativa entre os grupos religiosos com relação à aceitação dos aspectos científicos da teoria evolutiva neodarwinista (Tabela 5.7). 


\begin{tabular}{|lccccc|}
\hline Sample1-Sample2 & $\begin{array}{c}\text { Test } \\
\text { Statistic }\end{array}$ & $\begin{array}{c}\text { Std. } \\
\text { Error }\end{array}$ & $\begin{array}{c}\text { Std. Test } \\
\text { Statistic }\end{array}$ & Sig. & Adj.Sig. \\
\hline $\begin{array}{l}\text { Evangélico-Acredito em Deus, } \\
\text { mas não tenho religião }\end{array}$ & 32,680 & 17,072 & 1,914 &, 056 &, 556 \\
\hline Evangélico-Católico & 34,274 & 16,576 & 2,068 &, 039 &, 387 \\
\hline Evangélico-Outro & $-56,108$ & 26,159 & $-2,145$ &, 032 &, 320 \\
\hline Evangélico-Ateu & 88,726 & 37,294 & 2,379 &, 017 &, 174 \\
\hline $\begin{array}{l}\text { Acredito em Deus, mas não } \\
\text { tenho religião-Católico }\end{array}$ & $-1,595$ & 17,020 &,- 094 &, 925 & 1,000 \\
\hline $\begin{array}{l}\text { Acredito em Deus, mas não } \\
\text { tenho religião-Outro }\end{array}$ & $-23,428$ & 26,442 &,,- 886 &, 376 & 1,000 \\
\hline $\begin{array}{l}\text { Acredito em Deus, mas não } \\
\text { tenho religião-Ateu }\end{array}$ & $-56,047$ & 37,494 & $-1,495$ &, 135 & 1,000 \\
\hline Católico-Outro & $-21,833$ & 26,125 &,- 836 &, 403 & 1,000 \\
\hline Católico-Ateu & 32,618 & 42,410 &, 769 &, 442 & 1,000 \\
\hline Outro-Ateu & 54,452 & 37,270 & 1,461 &, 144 & 1,000 \\
\hline
\end{tabular}

Each row tests the null hypothesis that the Sample 1 and Sample 2 distributions are the same.

Asymptotic significances (2-sided tests) are displayed. The significance level is ,05.

Tabela 5.7: Testes post hoc ao de Kruskal-Wallis para o Fator AC.

Com relação ao fator NB, as diferenças foram significativas apenas para os cruzamentos que envolviam ateus ou evangélicos (Tabela 5.8). Isto indica que os ateus tendem a aceitar menos a narrativa Bíblica para a origem e evolução das espécies e os evangélicos tendem a aceitá-la mais dos que os outros grupos. 


\begin{tabular}{|lccccc|}
\hline Sample1-Sample2 & $\begin{array}{c}\text { Test } \\
\text { Statistic }\end{array}$ & $\begin{array}{l}\text { Std. } \\
\text { Error }\end{array}$ & $\begin{array}{l}\text { Std. Test } \\
\text { Statistic }\end{array}$ & Sig. & Adj.Sig. \\
\hline $\begin{array}{l}\text { Ateu-Acredito em Deus, mas não } \\
\text { tenho religião }\end{array}$ & 125,195 & 37,494 & 3,339 &, 001 &, 008 \\
\hline Ateu-Católico & $-126,706$ & 37,270 & $-3,400$ &, 001 &, 007 \\
\hline Ateu-Outro & $-160,353$ & 42,410 & $-3,781$ &, 000 &, 002 \\
\hline Ateu-Evangélico & $-240,593$ & 37,294 & $-6,451$ &, 000 &, 000 \\
\hline $\begin{array}{l}\text { Acredito em Deus, mas não } \\
\text { tenho religião-Católico }\end{array}$ & $-1,511$ & 17,020 &,- 089 &, 929 & 1,000 \\
\hline $\begin{array}{l}\text { Acredito em Deus, mas não } \\
\text { tenho religião-Outro }\end{array}$ & $-35,158$ & 26,442 & $-1,330$ &, 184 & 1,000 \\
\hline $\begin{array}{l}\text { Acredito em Deus, mas não } \\
\text { tenho religião-Evangélico }\end{array}$ & $-115,399$ & 17,072 & $-6,759$ &, 000 &, 000 \\
\hline Católico-Outro & $-33,647$ & 26,125 & $-1,288$ &, 198 & 1,000 \\
\hline Católico-Evangélico & $-113,888$ & 16,576 & $-6,871$ &, 000 &, 000 \\
\hline Outro-Evangélico & 80,240 & 26,159 & 3,067 &, 002 &, 022 \\
\hline
\end{tabular}

Each row tests the null hypothesis that the Sample 1 and Sample 2 distributions are the same.

Asymptotic significances (2-sided tests) are displayed. The significance level is ,05.

Tabela 5.8: Testes post hoc ao de Kruskal-Wallis para o Fator NB. Em destaque, estão os cruzamentos diferentes com a significância ajustada.

Realizamos também o teste $\mathrm{H}$ de Kruskal-Wallis para ambos os fatores com relação às turmas pesquisadas. Para o fator $\mathrm{AC}$, o teste foi significativo $(\mathrm{H}$ $(20)=37,629, p<0,05)$, porém os testes post-hoc com a significância ajustada se revelaram não significativos. Isto quer dizer que as diferenças do fator AC para as turmas pesquisadas não são significativas. Já o teste $\mathrm{H}$ para o fator NB foi não significativo $(\mathrm{H}(20)=29,837, \mathrm{p}>0,05)$, o que indica que não há diferenças do fator NB entre as turmas.

\section{2 .2}

\section{Construção do índice de entendimento da teoria evolutiva neodarwinista}

A fim de medir o entendimento dos estudantes pesquisados sobre a teoria evolutiva neodarwinista, utilizamos as questões de números 13 a 24 do questionário (Apêndice 1). Após a inserção das respostas na base de dados, 
recodificamo-las em variáveis dummies $^{53}$ atribuindo 0 para respostas incorretas e 1 para respostas corretas. A Tabela 5.9 mostra as frequências de respostas certas e erradas para cada uma das questões. A questão com maior frequência de acertos $(69,9 \%)$ foi a 17 , que versava sobre alterações no DNA, chamadas de mutação (alternativa correta). Já a de menor índice de acertos $(5,0 \%)$ foi a 23 que perguntava sobre as ideias evolucionistas de Lamarck e a resposta correta era a "Herança de características adquiridas". Esse resultado causa certo estranhamento, pois este foi um dos pontos mais abordados por todos os professores pesquisados e é explicitamente prescrito pelo Currículo Mínimo (Anexo 1) a ser estudado no terceiro bimestre (segundo tópico: "Comparar, a partir de textos científicos e históricos, as teorias evolucionistas de Lamarck, Darwin e neodarwinista").Assim, é possível que haja algum tipo de obstáculo para o entendimento deste conteúdo que deve ser enfrentado pelos professores e estudantes pesquisados.

\begin{tabular}{ccc}
\hline Questão & Certo (\%) & Errado (\%) \\
\hline $\mathbf{1 3}$ & 16,3 & 83,7 \\
$\mathbf{1 4}$ & 27,0 & 73,0 \\
$\mathbf{1 5}$ & 15,2 & 84,8 \\
$\mathbf{1 6}$ & 48,6 & 51,4 \\
$\mathbf{1 7}$ & 69,9 & 30,1 \\
$\mathbf{1 8}$ & 26,8 & 73,2 \\
$\mathbf{1 9}$ & 30,9 & 69,1 \\
$\mathbf{2 0}$ & 50,5 & 49,5 \\
$\mathbf{2 1}$ & 14,0 & 86,0 \\
$\mathbf{2 2}$ & 7,2 & 92,8 \\
$\mathbf{2 3}$ & 5,0 & 95,0 \\
$\mathbf{2 4}$ & 23,3 & 76,7 \\
\hline
\end{tabular}

Tabela 5.9: Frequências (porcentagem) de respostas certas e erradas para cada uma das questões de entendimento da teoria evolutiva neodarwinista.

Em seguida, criamos uma nova variável somando os escores obtidos pelos estudantes em todas essas questões. O Gráfico 5.7 mostra as frequências do entendimento da evolução para todos os participantes da pesquisa.

\footnotetext{
${ }^{53}$ Uma variável dummy é uma variável numérica criada a partir de uma variável categórica. Por exemplo, a questão 13 de nosso questionário comportava cinco alternativas (categorias) diferentes. Nesse momento de nossa análise, importa saber quantos estudantes acertaram e quantos erraram essa questão. Portanto, as alternativas erradas foram transformadas em 0 e a correta em 1. Essa modificação é necessária para que alguns testes possam ser realizados, como as correlações (mais adiante), e produzam resultados que possam ser interpretados.
} 


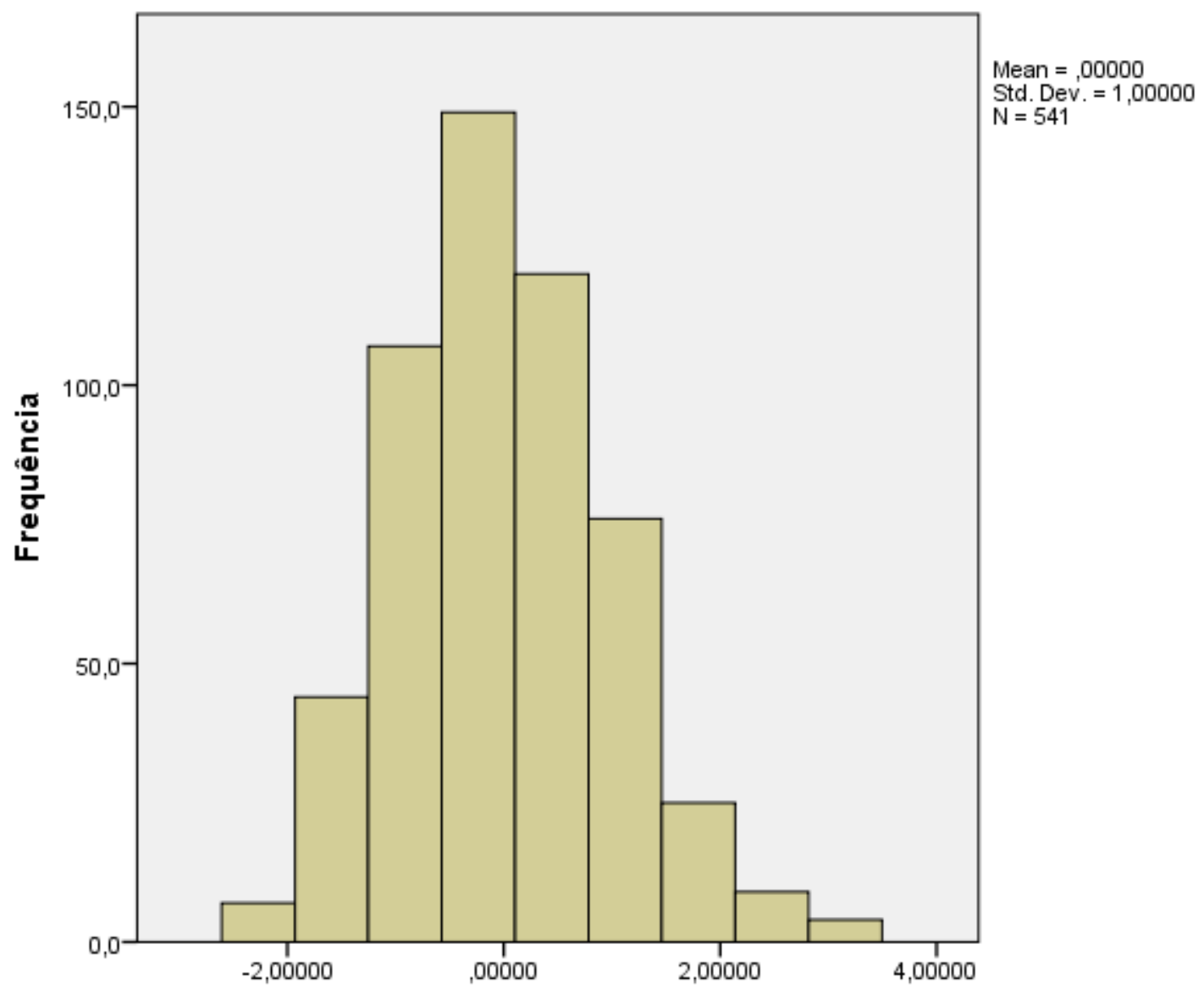

Zscore: Entendimento de evolução

Gráfico 5.7: Frequências do escore de entendimento de evolução. Mediana =-0,234391.

Os resultados por escola são indicados nos Gráficos 5.8, 5.9 e na Tabela 5.10 e foram significativamente diferentes de acordo com o teste U de MannWhitney $(\mathrm{U}=24354,50, \mathrm{p}<0,05)$. As médias por grupo religioso são indicadas na Tabela 5.11 abaixo. Foi realizado o teste H de Kruskal-Wallis entre eles, que apontou que os escores do entendimento de evolução não são significativamente diferentes $(\mathrm{H}(4)=5,182, \mathrm{p}>0,05)$. Esses resultados indicam que há diferença no entendimento da evolução entre os estudantes das duas escolas, mas não entre os grupos religiosos. 


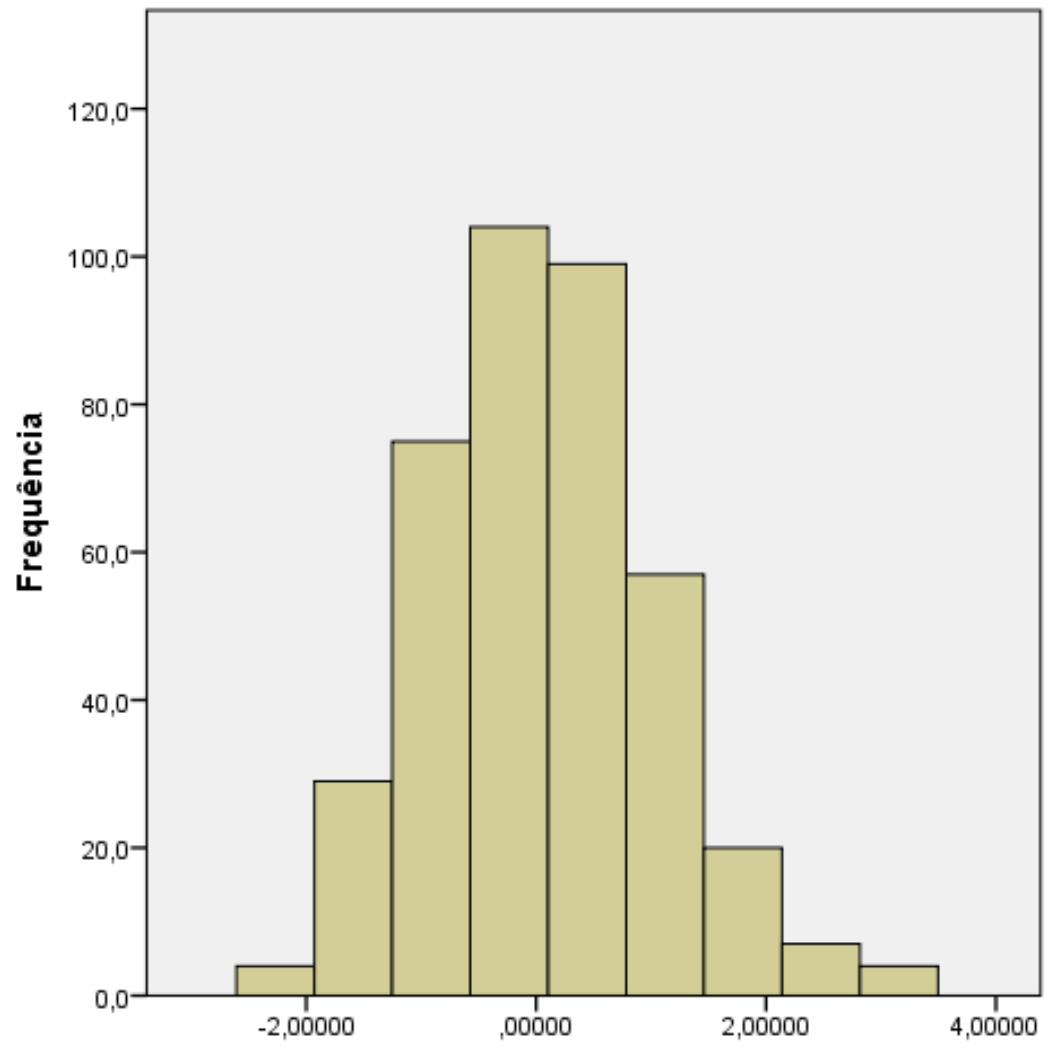

Zscore: Entendimento de evolução

Gráfico 5.8: Frequências do escore de entendimento de evolução dos estudantes do Colégio Guarani.

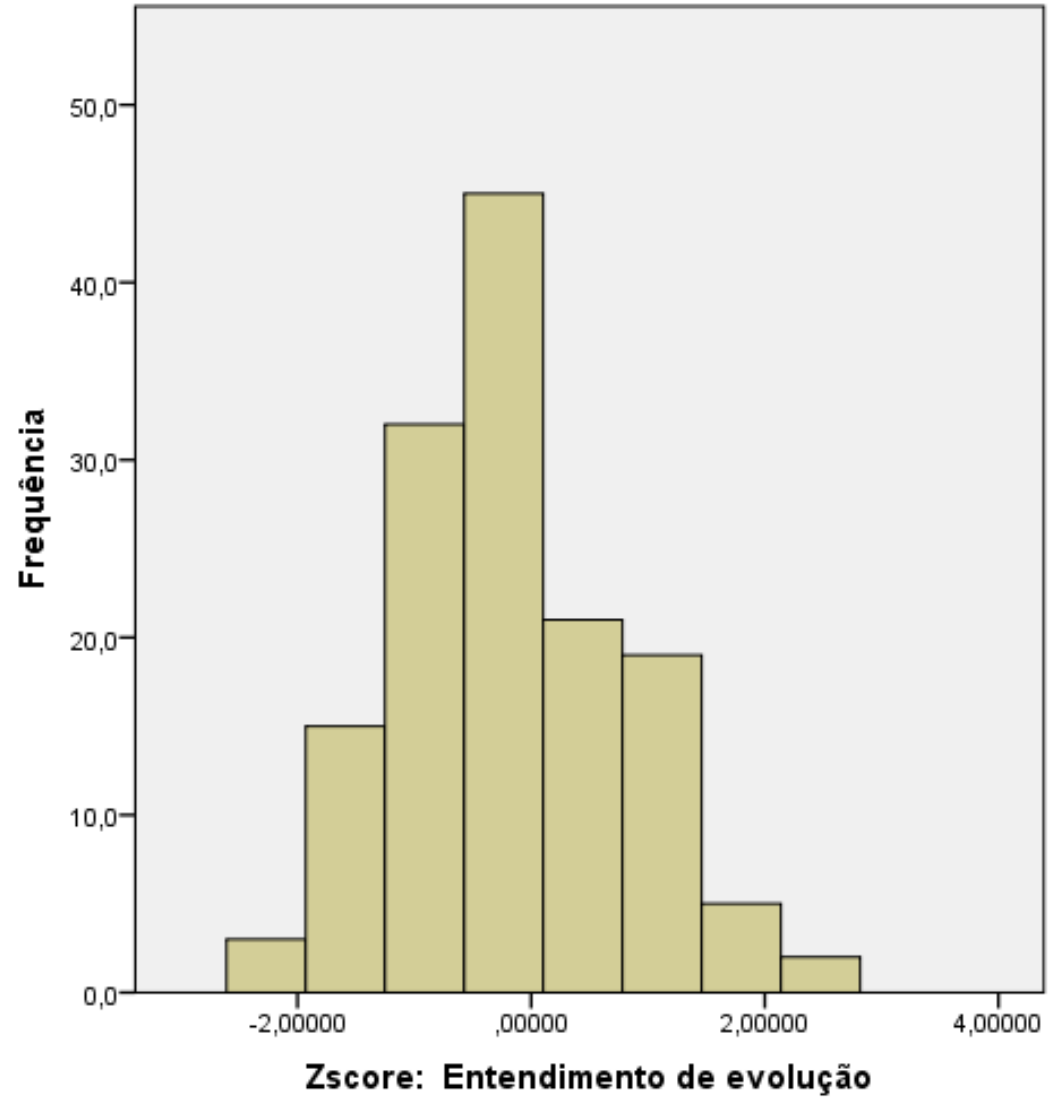

Gráfico 5.9: Frequências do escore de entendimento de evolução dos estudantes do Colégio Guarani 


\begin{tabular}{lrcrr}
\hline \multicolumn{5}{c}{ Escore de entendimento de evolução } \\
\hline Escola & N & Média & Desvio padrão & Mediana \\
Guarani & 399 & 0,064723 & 1,001626 & $-0,23439$ \\
Passaredo & 142 & $-0,18186$ & 0,976085 & $-0,23439$ \\
Total & 541 & 0,00 & 1,00 & $-0,23439$ \\
\hline
\end{tabular}

Tabela 5.10: Média, desvio padrão e mediana do escore de entendimento da evolução por escola.

\begin{tabular}{lcrrrr}
\hline \multicolumn{5}{c}{ Escore de entendimento de evolução } \\
\hline Religião & Média & $\mathbf{N}$ & Desvio padrão & Mediana \\
\hline Acredito em Deus, mas não tenho religião & 0,043222 & 149 & 0,965484 & $-0,23439$ \\
\hline Ateu & 0,403824 & 17 & 0,846631 & 0,443713 \\
Católico & $-0,06696$ & 162 & 1,069005 & $-0,23439$ \\
Evangélico & $-0,02854$ & 168 & 0,952527 & $-0,23439$ \\
\hline Outro & 0,023935 & 42 & 1,110228 & $-0,23439$ \\
\hline Total & $-0,00247$ & 538 & 1,002238 & $-0,23439$ \\
\hline
\end{tabular}

Tabela 5.11: Médias do escore de entendimento de evolução para os grupos de religião.

\section{2 .3}

\section{Construção do índice de religiosidade}

Um terceiro índice importante para a nossa pesquisa é o de religiosidade dos estudantes participantes. Como discutimos anteriormente, as variáveis utilizadas para construí-lo foram adaptadas da versão em português do Índice de Religiosidade da Universidade de Duke, DUREL (KOENIG; BÜSSING, 2010; MOREIRA-ALMEIDA et al., 2008). As questões utilizadas se dividem em três subgrupos: Religiosidade Intrínseca (RI, 25, 26 e 27), Religiosidade Organizacional (RO, 28) e Religiosidade Não-organizacional (RNO, 29). Os autores recomendam que essas variáveis não sejam usadas em um único fator, pois estudos verificaram que as dimensões podem ter correlações distintas com outras variáveis pesquisadas ${ }^{54}$.

Para a construção da dimensão de RI, realizamos a análise fatorial exploratória das questões 25, 26 e 27. Obtivemos um único fator, cujas cargas além das estatísticas de adequação da amostra e consistência interna estão mostradas na Tabela 5.12 abaixo:

\footnotetext{
${ }^{54}$ Koenig (2008) e Koenig e Büssing(2010) afirmam que estudos sobre depressão e derrames indicam que a religiosidade organizacional está inversamente correlacionada com eles enquanto que a religiosidade não organizacional se relaciona positivamente.
} 


\begin{tabular}{|c|c|}
\hline \multicolumn{2}{|l|}{ Matriz de fatores ${ }^{a}$} \\
\hline Variáveis & Fator \\
\hline Em minha vida, eu sinto a presença divina. & 0,792 \\
\hline $\begin{array}{l}\text { As minhas crenças religiosas são muito importantes } \\
\text { para toda a minha maneira de viver. }\end{array}$ & 0,877 \\
\hline $\begin{array}{l}\text { Eu me esforço muito para seguir os preceitos da minha } \\
\text { religião em todos os aspectos da vida. }\end{array}$ & 0,817 \\
\hline \multicolumn{2}{|c|}{$\begin{array}{l}\text { Método de Extração: Principal Component Analysis. } \\
\text { a. } 1 \text { fator extraído. } \\
\qquad \begin{array}{r}\text { Variância explicada }=68,770 \% \\
\text { KMO }=0,669 \\
\text { Alfa de Cronbach }=0,772\end{array}\end{array}$} \\
\hline
\end{tabular}

Tabela 5.12: Análise fatorial para os itens de religiosidade intrínseca (RI).

As frequências da RI para as duas escolas são mostradas nos Gráficos 5.10 (Guarani) e 5.11 (Passaredo) e se mostraram significativamente diferentes. O Colégio Guarani $($ Mediana $=0,15)$ teve RI menor do que o Passaredo (Mediana $=$ $0,43), U=21876,50, p<0,005$. Isto indica que os estudantes do colégio carioca tendem a manifestar menor grau de compromisso ou motivação religiosa pessoais do que os do colégio nilopolitano.

Em relação aos grupos de religião, suas médias, medianas e desvio-padrão para a RI podem ser vistos na tabela 5.13, a seguir. O teste $\mathrm{H}$ de Kruskal-Wallis (Figura 5.4) indicou que as médias são significativamente diferentes entre si $(\mathrm{H}$ $(4)=123,58, p<0,001)$. Já os testes U de Mann-Whitney post-hoc indicaram que todas as médias são significativamente diferentes entre si, exceto pelos pares “Acredito em Deus, mas não tenho religião" e "Outro" $(U=2163,00, p>0,005)$ e "Católico" e "Outro" ( $p>0,05)$. 
Histograma

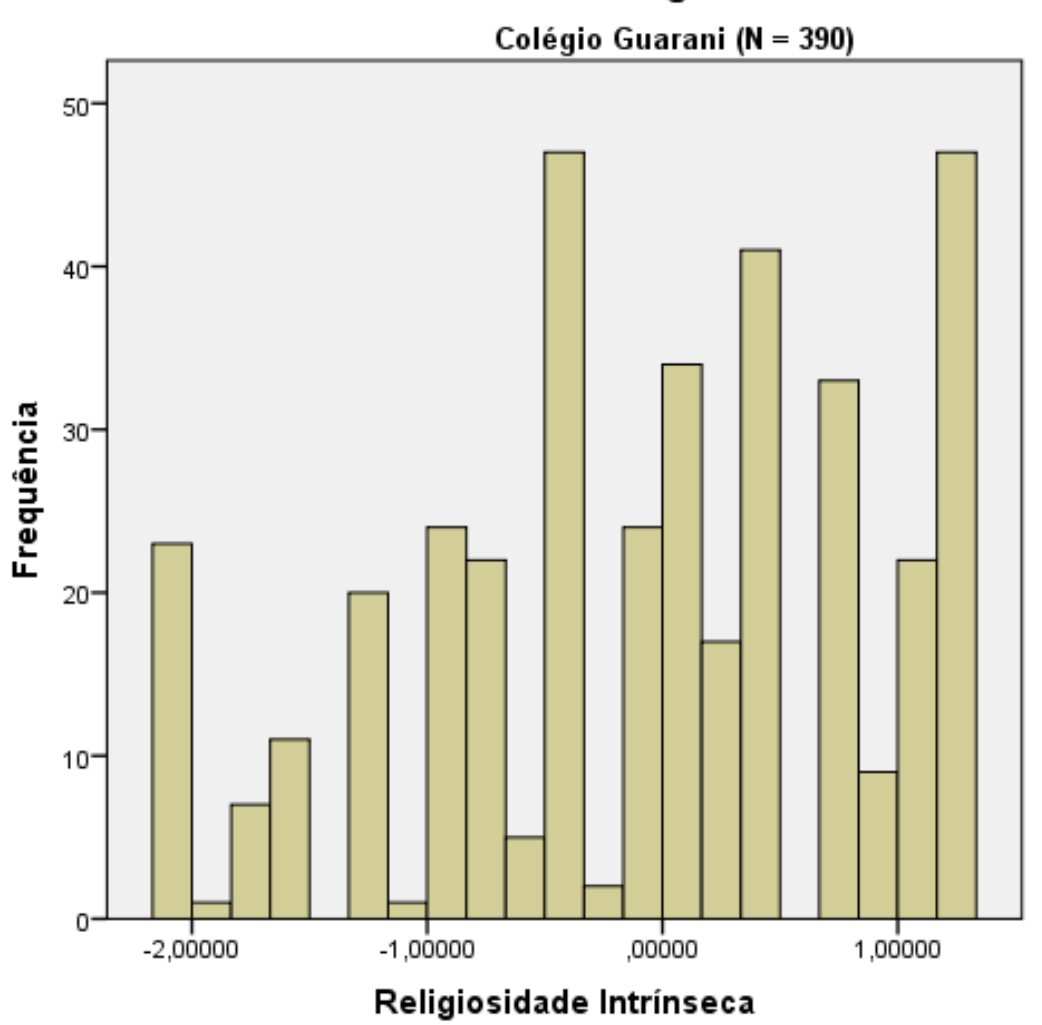

Gráfico 5.10: Frequências da Religiosidade Intrínseca (RI) para os estudantes do Colégio Guarani. Média = -0,7337; Desvio padrão = 0,96733; Mediana =0,15.

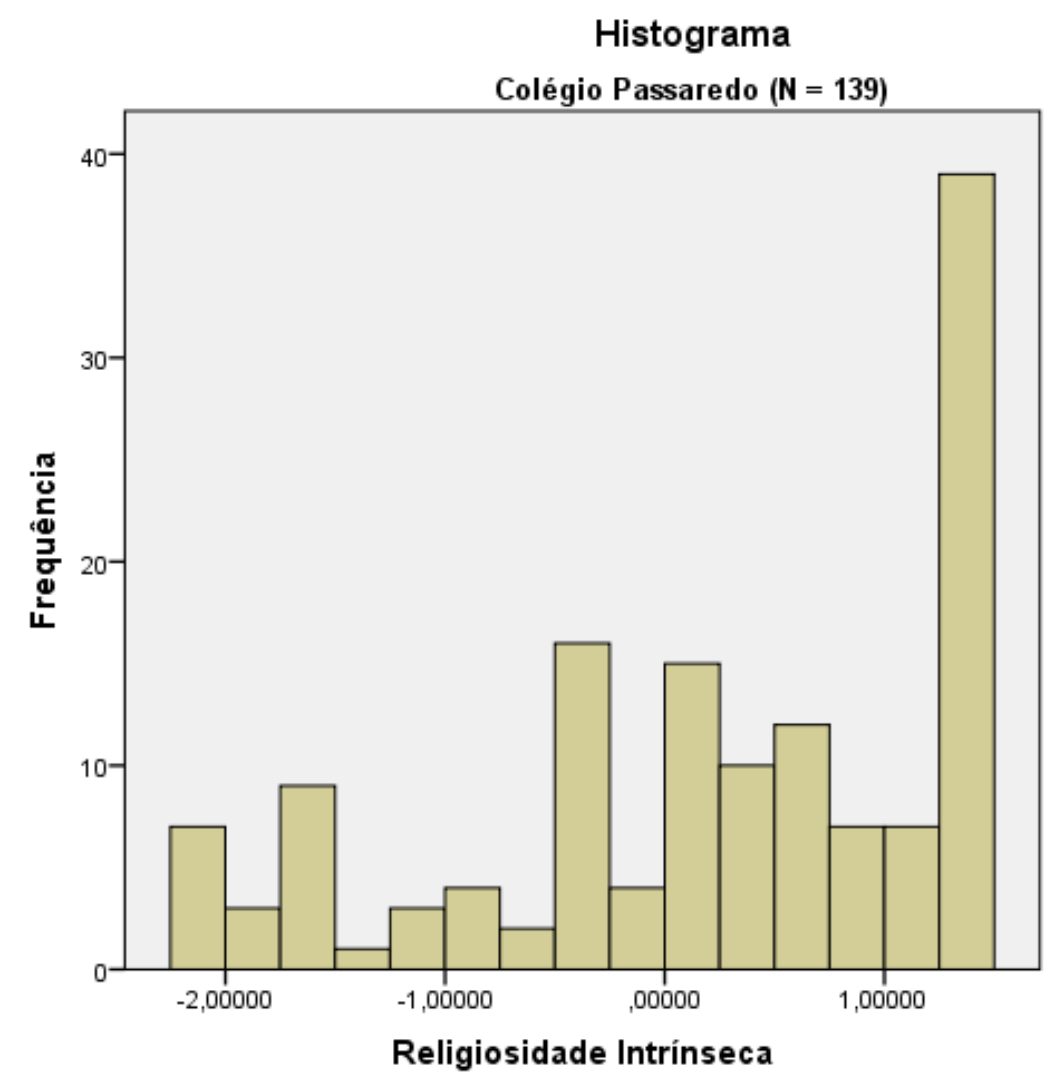

Gráfico 5.11: Frequências da Religiosidade Intrínseca (RI) para os estudantes do Colégio Passaredo. Média = 0,20587; Desvio padrão = 1,06325; Mediana =0,43. 


\begin{tabular}{lrrrr}
\hline \multicolumn{5}{c}{ Religiosidade Intrínseca } \\
\hline Religião & \multicolumn{1}{c}{ N } & Média & Desvio padrão & \multicolumn{1}{l}{ Mediana } \\
\hline $\begin{array}{l}\text { Acredito em Deus, } \\
\text { mas não tenho religião }\end{array}$ & 145 & $-0,4719273$ & 0,91381950 & $-0,4150187$ \\
\hline Ateu & 16 & $-1,6708858$ & 0,77142082 & $-2,1084722$ \\
\hline Católico & 161 & 0,0445701 & 0,81194926 & 0,1649649 \\
\hline Evangélico & 164 & 0,5485564 & 0,85395586 & 0,8634312 \\
\hline Outro & 41 & $-0,0072837$ & 1,07327104 & 0,1519068 \\
\hline Total & 527 & 0,0031817 & 1,00021901 & 0,1519068 \\
\hline
\end{tabular}

Tabela 5.13: Média, desvio padrão e mediana da Religiosidade Intrínseca para os grupos religiosos.

É interessante notar que a média da RI para os estudantes evangélicos é a maior entre os cinco grupos analisados. O efeito é maior quando comparados aos acreditam em Deus, mas não têm religião $(U=4716,00, r=-0,52, p<0,005)$, seguido por ateus $(\mathrm{U}=105,50, \mathrm{r}=-0,46, \mathrm{p}<0,005)$, católicos $(\mathrm{U}=8003,50 \mathrm{r}=$ $0,34, p<0,005)$ e outros $(U=2301,50, r=-0,22, p<0,005)$.

Independent-Samples Kruskal-Wallis Test

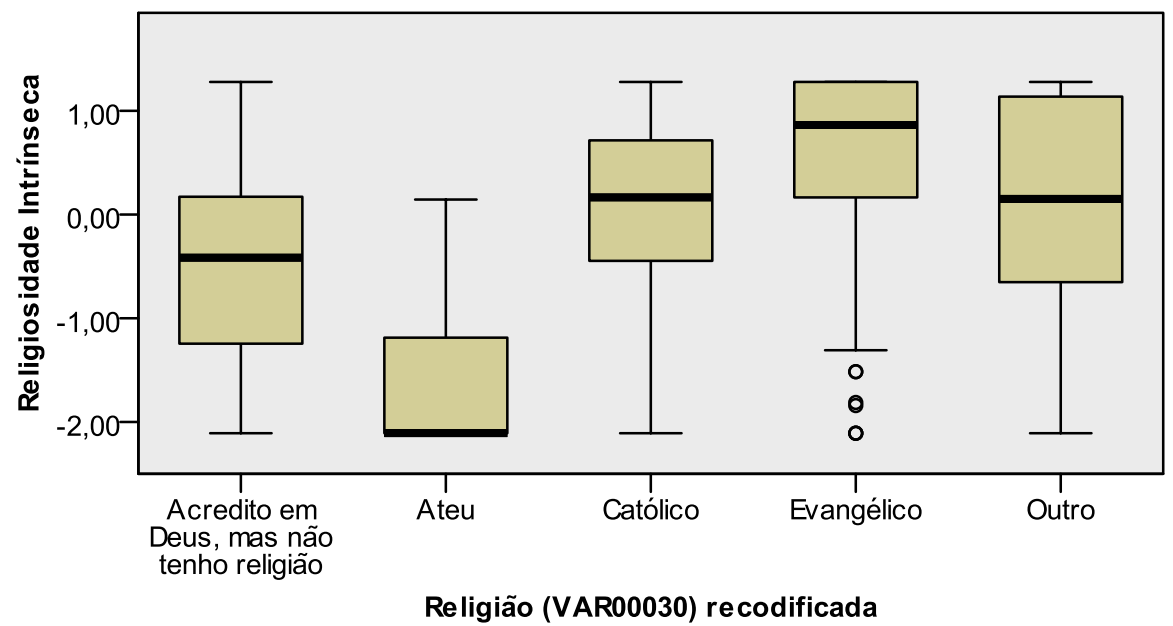

\begin{tabular}{|lr|}
\hline Total N & 527 \\
\hline Test Statistic & 123,583 \\
\hline Degrees of Freedom & 4 \\
\hline Asymptotic Sig. (2-sided test) &, 000 \\
\hline
\end{tabular}

1. The test statistic is adjusted for ties.

Figura 5.3: Acima: Diagrama de box-plot de frequências da Religiosidade Intrínseca de acordo com os grupos religiosos. Abaixo: Resultado do teste $\mathrm{H}$ de Kruskal-Wallis. 
Além da RI, analisamos as a RO (Religiosidade Organizacional) e a RNO (Religiosidade Não-organizacional). Como essas duas dimensões foram definidas por uma única variável cada (questões 28 e 29, respectivamente), não faz sentido utilizar a análise fatorial exploratória para investigá-las. Assim, estudamos as médias dessas variáveis para as escolas e para os grupos religiosos. Para facilitar a compreensão e análise dos dados, os escores dessas questões foram revertidos. Dessa maneira, quanto maior o escore obtido pelo estudante, maior a $\mathrm{RO}$ e a RNO.

Para a RO (questão 28) os resultados por escola são apresentados a seguir (Tabela 5.14, Gráficos 5.12 e 5.13). Foi realizado o teste U de Mann-Whitney que apontou que os estudantes do Colégio Guarani (Mediana = -0,392) apresentam menor RO do que os do Passaredo (Mediana = 0,797), $U=19833,50, p<0,001, r$ $=-0,22$.

\begin{tabular}{lccrc}
\hline Escola & Média & N & Desvio padrão & Mediana \\
\hline Guarani & $-0,1286679$ & 399 & 0,96667914 & $-0,3926231$ \\
Passaredo & 0,3693418 & 139 & 1,00547211 & 0,7974119 \\
Total & 0,0000000 & 538 & 1,00000000 & $-0,3926231$ \\
\hline
\end{tabular}

Tabela 5.14: Média, desvio padrão e mediana da RO para as escolas pesquisadas.

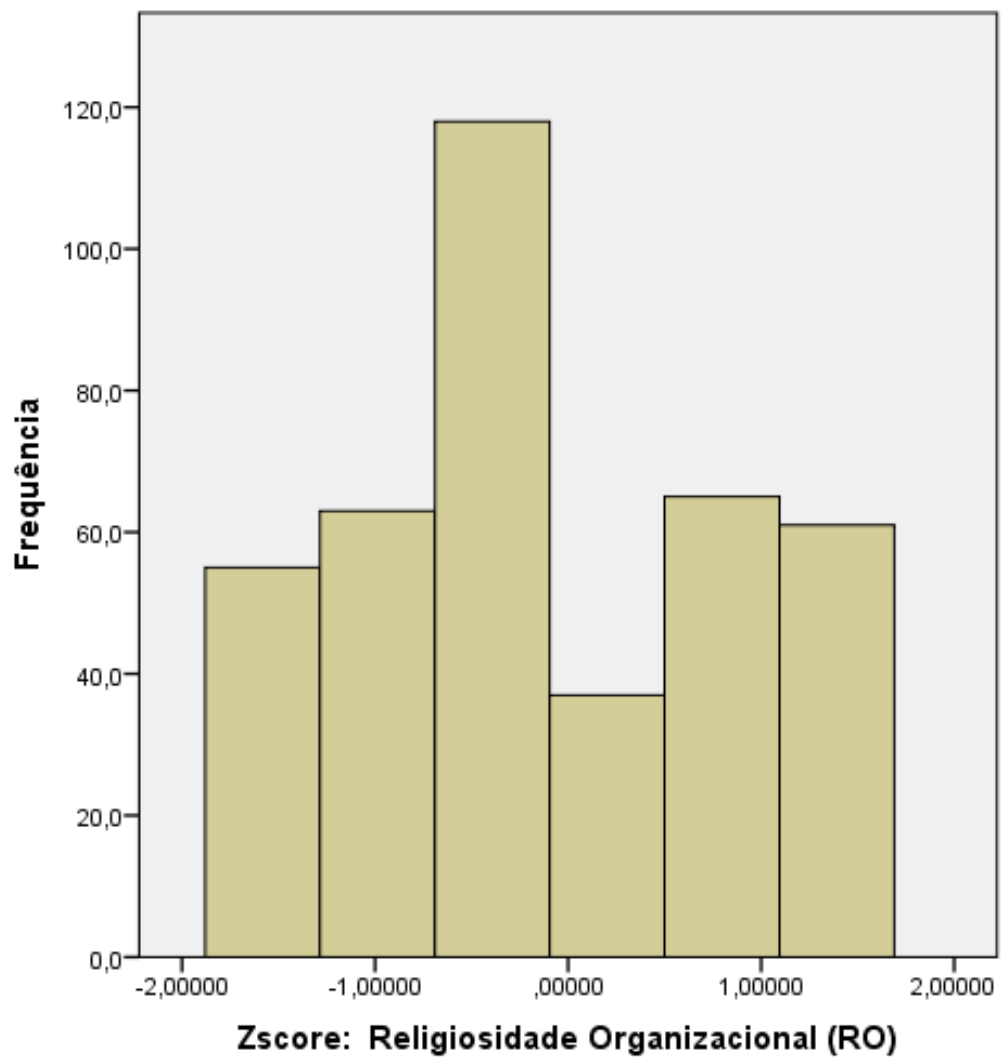

Gráfico 5.12: Frequências da Religiosidade Organizacional (RO) para os estudantes do Colégio Guarani. 


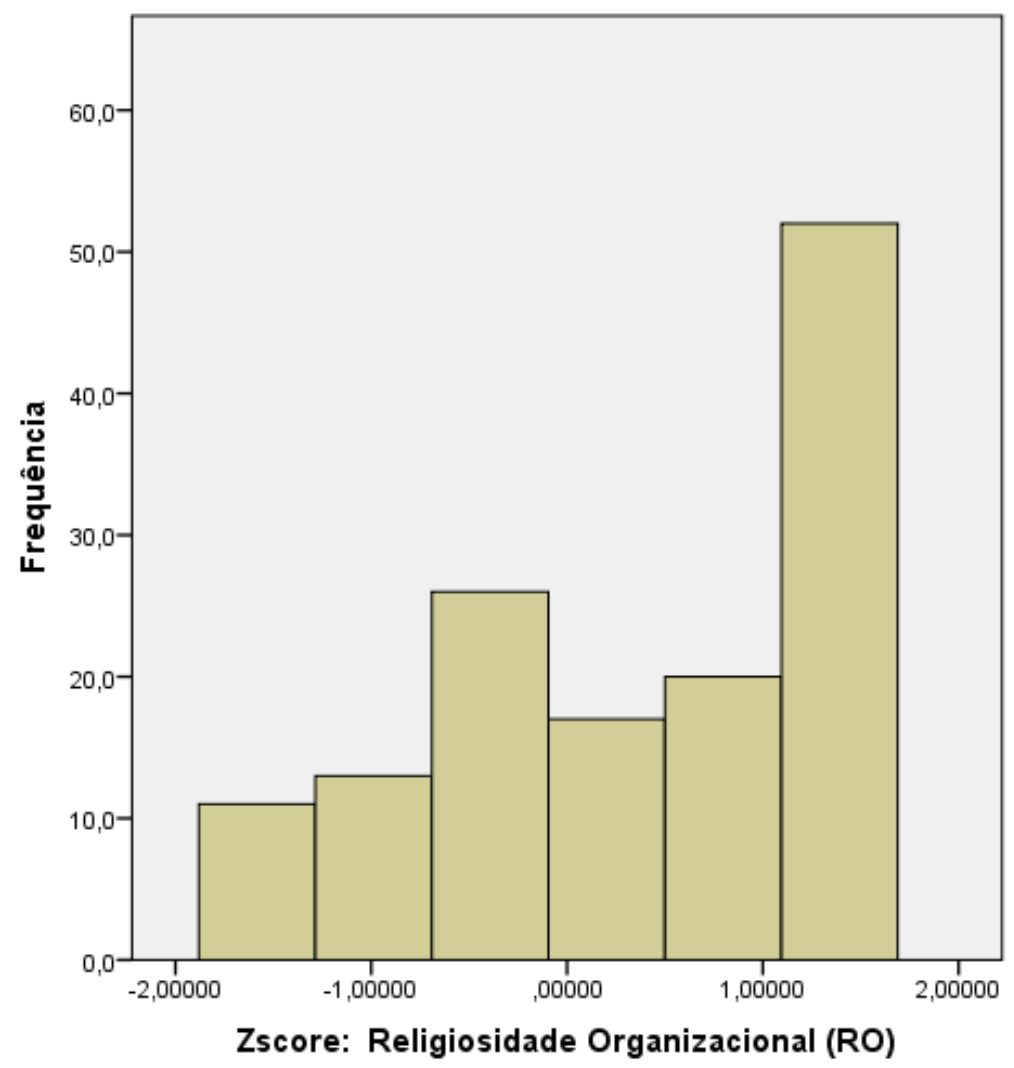

Gráfico 5.13: Frequências da Religiosidade Organizacional (RO) para os estudantes do Colégio Passaredo.

Com relação aos grupos de religião, os resultados são mostrados na Tabela 5.15. O teste $\mathrm{H}$ de Kruskal-Wallis apontou que as diferenças entre esses grupos são significativas $(\mathrm{H}(4)=209,599 \mathrm{p}<0,001)$. Os testes post-hoc realizados indicaram que as diferenças são significativas para todos os pares, exceto "Ateu $\mathrm{x}$ Acredito em Deus, mas não tenho religião" e "Católico x Outro" (Figura 5.4).

\begin{tabular}{lcccc}
\hline \multicolumn{5}{c}{ Religiosidade Organizacional (RO) } \\
\hline Religião & Média & N & $\begin{array}{c}\text { Desvio } \\
\text { Padrão }\end{array}$ & Mediana \\
$\begin{array}{l}\text { Acredito em Deus, mas não tenho } \\
\text { religião }\end{array}$ & $-0,7200824$ & 149 & 0,73344414 & $-0,9876406$ \\
Ateu & $-1,1626457$ & 17 & 0,78049157 & $-1,5826581$ \\
Católico & $-0,0326742$ & 162 & 0,78007072 & $-0,3926231$ \\
Evangélico & 0,8045379 & 167 & 0,75033976 & 1,3924294 \\
Outro & $-0,0152949$ & 41 & 1,07890389 & $-0,3926231$ \\
\hline Total & 0,0025751 & 536 & 1,00080982 & $-0,3926231$ \\
\hline
\end{tabular}

Tabela 5.15: Médias, desvio padrão e mediana da Religiosidade Organizacional (RO) para os grupos de religião. 
Pairwise Comparisons of Religião (VAR00030) recodificada

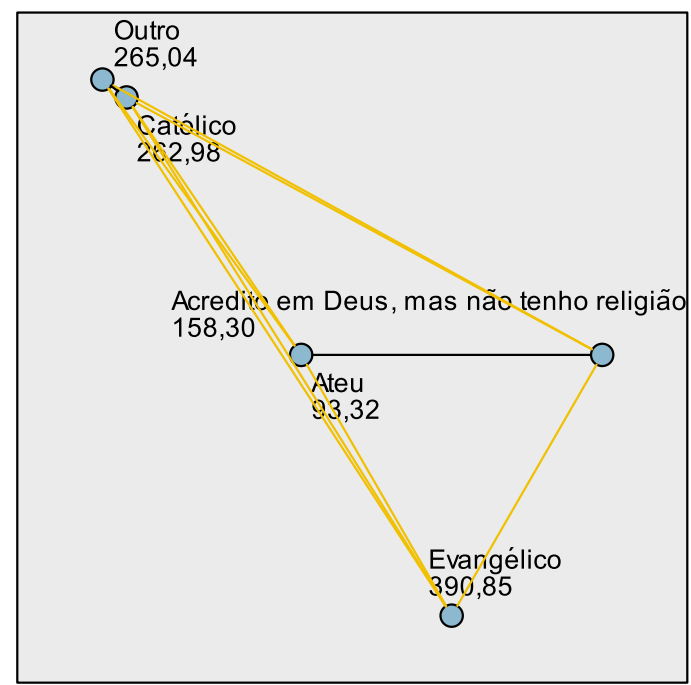

Each node shows the sample average rank of Religião (VAR00030) recodificada.

\begin{tabular}{|lrrrrr|}
\hline Sample1-Sample2 & $\begin{array}{c}\text { Test } \\
\text { Statistic }\end{array}$ & $\begin{array}{l}\text { Std. } \\
\text { Error }\end{array}$ & $\begin{array}{l}\text { Std. Test } \\
\text { Statistic }\end{array}$ & Sig. & Adj.Sig. \\
\hline $\begin{array}{l}\text { Ateu-Acredito em Deus, mas não } \\
\text { tenho religião }\end{array}$ & 64,978 & 38,887 & 1,671 &, 095 &, 947 \\
\hline Ateu-Católico & $-169,661$ & 38,727 & $-4,381$ &, 000 &, 000 \\
\hline Ateu-Outro & $-171,713$ & 43,820 & $-3,919$ &, 000 &, 001 \\
\hline Ateu-Evangélico & $-297,530$ & 38,672 & $-7,694$ &, 000 &, 000 \\
\hline $\begin{array}{l}\text { Acredito em Deus, mas não } \\
\text { tenho religião-Católico }\end{array}$ & $-104,683$ & 17,243 & $-6,071$ &, 000 &, 000 \\
\hline $\begin{array}{l}\text { Acredito em Deus, mas não } \\
\text { tenho religião-Outro }\end{array}$ & $-106,735$ & 26,789 & $-3,984$ &, 000 &, 001 \\
\hline $\begin{array}{l}\text { Acredito em Deus, mas não } \\
\text { tenho religião-Evangélico }\end{array}$ & $-232,551$ & 17,118 & $-13,585$ &, 000 &, 000 \\
\hline Católico-Outro & $-2,052$ & 26,557 &,- 077 &, 938 & 1,000 \\
\hline $\begin{array}{l}\text { Católico-Evangélico } \\
\text { Outro-Evangélico }\end{array}$ & $-127,869$ & 16,752 & $-7,633$ &, 000 &, 000 \\
\hline
\end{tabular}

Each row tests the null hypothesis that the Sample 1 and Sample 2 distributions are the same.

Asymptotic significances (2-sided tests) are displayed. The significance level is ,05.

Figura 5.4: Testes post-hoc ao de Kruskal-Wallis para a RO. Acima: Diagrama mostrando as distâncias entre os grupos de religião. Os números representam as médias dos ranks de cada amostra. Abaixo: Em destaque, estão os cruzamentos diferentes com a significância ajustada.

Chama atenção que os evangélicos possuem as maiores médias e medianas, indicando que é o grupo que mais comparece a templos e encontros 
religiosos. O efeito é maior quando se compara os grupos "Acredito em Deus, mas não tenho religião" (Mediana = -0,99) com "Evangélico" $($ Mediana $=1,39), r$ $=-0,76$, seguido por "Ateu" (Mediana $=-1,58$ ) e "Evangélico", $r=-0,56$, e "Ateu" e "Outro" (Mediana $=-0,39), r=-0,514$.

Já em relação à Religiosidade Não Organizacional (RNO, questão 29), os dados por escola são apresentados na Tabela 5.16. Foi realizado o teste $U$ de Mann-Whitney que apontou que os estudantes do Colégio Guarani (Mediana = $0,24)$ apresentam menor RO do que os do Passaredo (Mediana $=0,33$ ), $\mathrm{U}=$ $24698,50, \mathrm{p}<0,05$, porém o efeito é pequeno, $\mathrm{r}=-0,09$. Comparando essa dimensão com a RI e a RO, a RNO é aquela em que as duas escolas menos se diferenciam.

\begin{tabular}{lccrc}
\hline \multicolumn{5}{c}{ Religiosidade Não Organizacional } \\
\hline Escola & N & Média & Desvio Padrão & Mediana \\
Guarani & 399 & $-0,0510608$ & 0,99652386 & $-0,2363829$ \\
Passaredo & 140 & 0,1455232 & 0,99912603 & 0,3324135 \\
Total & 539 & 0,0000000 & 1,00000000 & 0,3324135 \\
\hline
\end{tabular}

Tabela 5.16: Média, desvio padrão e mediana da RNO para as escolas pesquisadas.

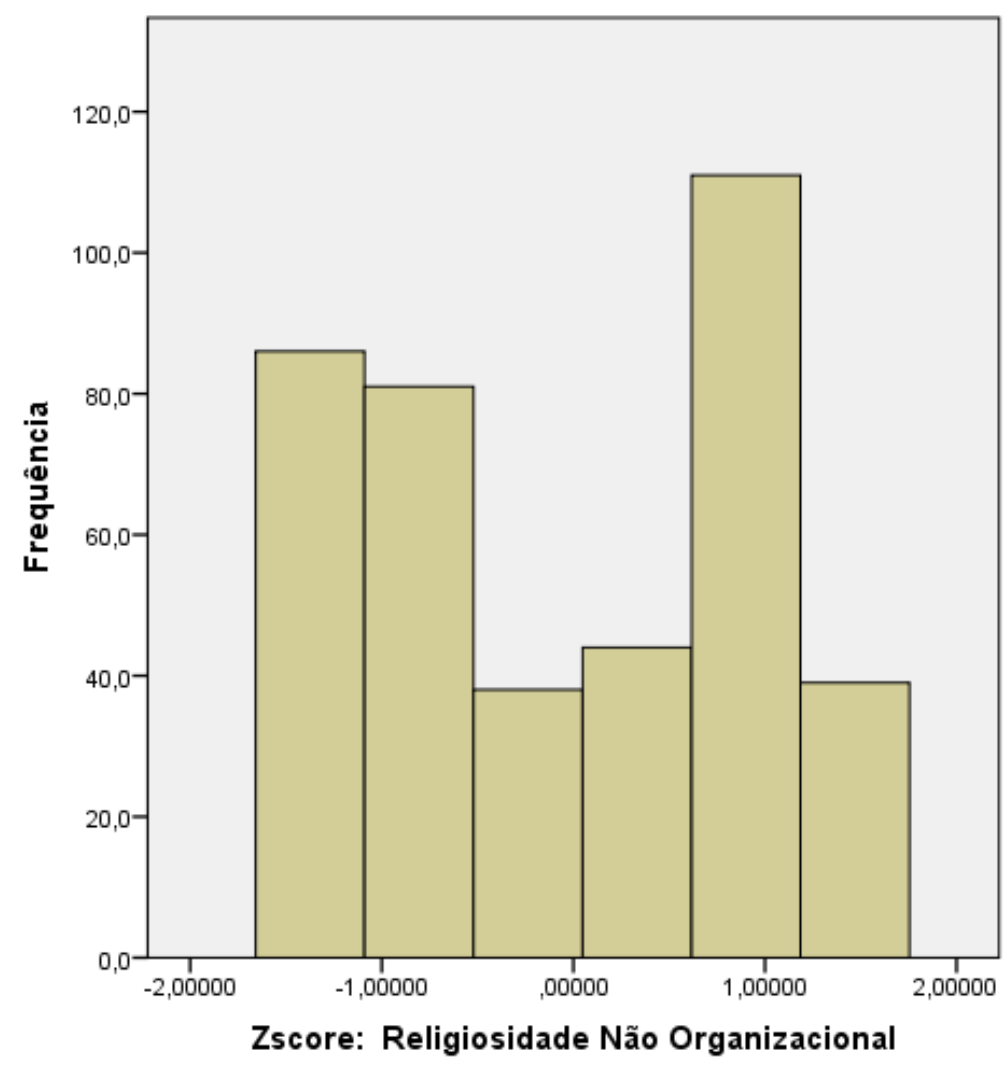

Gráfico 5.14: Frequências da Religiosidade Não Organizacional (RNO) para os estudantes do Colégio Guarani. 


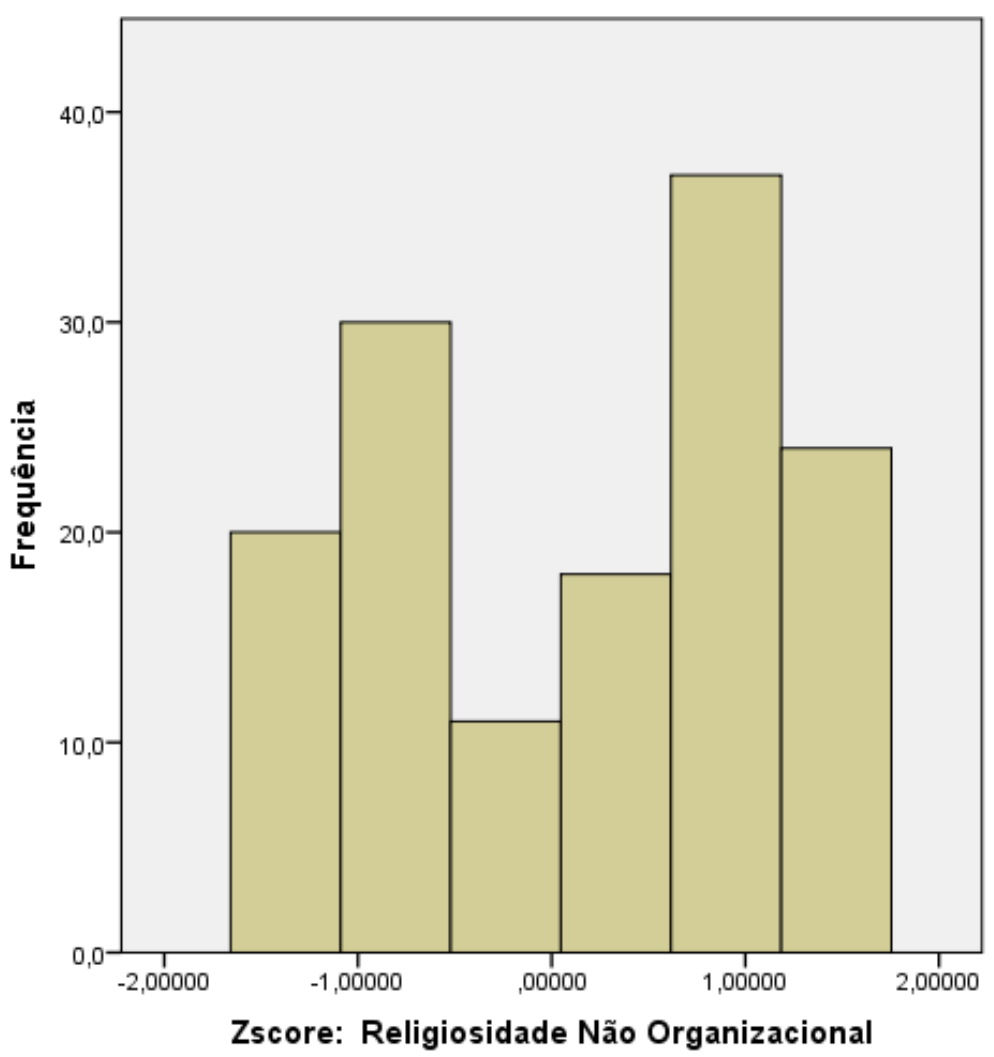

Gráfico 5.15: Frequências da Religiosidade Não Organizacional (RNO) para os estudantes do Colégio Passaredo.

Com relação aos grupos de religião, os resultados são mostrados na Tabela 5.17. O teste $\mathrm{H}$ de Kruskal-Wallis (Figura 5.5) apontou que as diferenças entre esses grupos são significativas (H (4) = 100,836 p <0,001). Os testes post-hoc realizados indicaram que as diferenças são significativas para todos os pares, exceto "Ateu x Acredito em Deus, mas não tenho religião", "Católico x Outro" e “Acredito em Deus, mas não tenho religião" e "Outro" (Figura 5.6).

\begin{tabular}{lcccc}
\hline \multicolumn{5}{c}{ Religiosidade Não Organizacional (RNO) } \\
\hline Religião & Média & N & $\begin{array}{l}\text { Desvio } \\
\text { Padrão }\end{array}$ & Mediana \\
$\begin{array}{l}\text { Acredito em Deus, mas não tenho } \\
\text { religião }\end{array}$ & $-0,5188725$ & 149 & 0,93655361 & $-0,8051794$ \\
\hline Ateu & & & & \\
\hline Católico & $-0,9390139$ & 17 & 0,91117153 & $-1,3739759$ \\
\hline Evangélico & 0,0620596 & 162 & 0,91254537 & 0,3324135 \\
\hline Outro & 0,5152409 & 168 & 0,84279172 & 0,9012100 \\
\hline Total & $-0,0282867$ & 41 & 0,99137239 & $-0,2363829$ \\
\hline
\end{tabular}

Tabela 5.17: Médias, desvio padrão e mediana da Religiosidade Organizacional (RO) para os grupos de religião. 


\section{Independent-Samples Kruskal-Wallis Test}

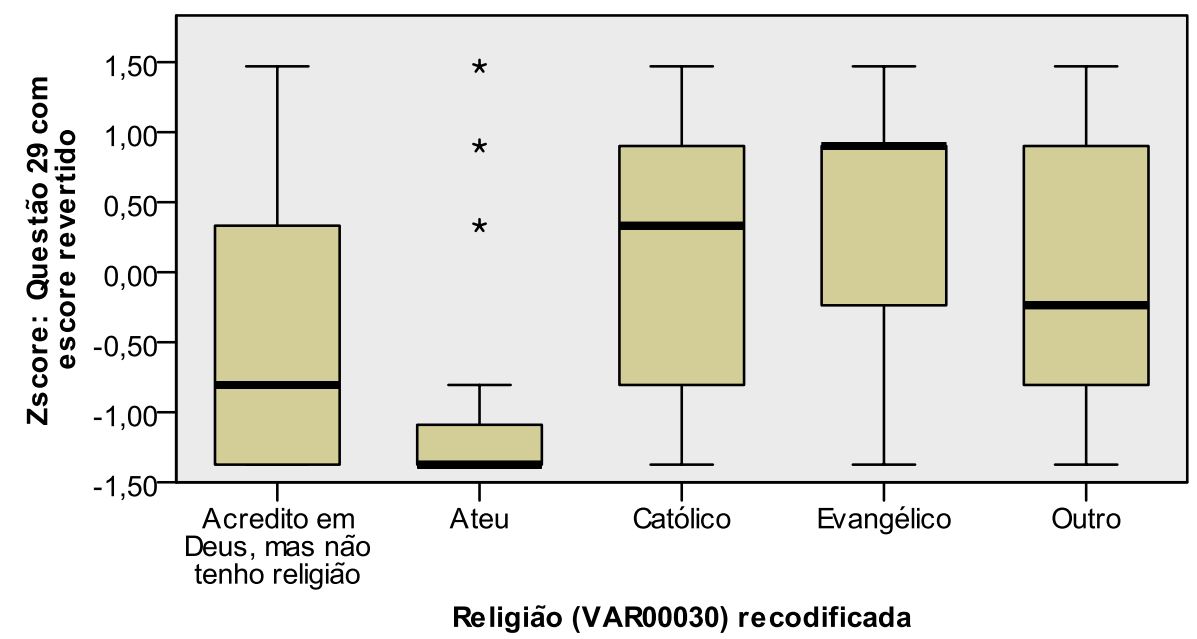

\begin{tabular}{|lr|}
\hline Total N & 537 \\
\hline Test Statistic & 100,836 \\
\hline Degrees of Freedom & 4 \\
\hline Asymptotic Sig. (2-sided test) &, 000 \\
\hline
\end{tabular}

1. The test statistic is adjusted for ties.

Figura 5.5: Acima: Diagrama de box-plot de frequências da Religiosidade Intrínseca de acordo com os grupos religiosos. Abaixo: Resultado do teste $\mathrm{H}$ de Kruskal-Wallis.

Chama atenção que os evangélicos possuem as maiores médias e medianas, indicando que estes alunos são os que mais realizam atividades religiosas individuais. O efeito é maior quando se compara os grupos "Acredito em Deus, mas não tenho religião" (Mediana = -0,80) com "Evangélico" (Mediana $=0,90), r=-0,51$, seguido por "Ateu" (Mediana $=-1,37)$ e "Evangélico", $r=-$ 0,43, "Ateu" e "Outro" (Mediana = -0,24), $\mathrm{r}=-0,43$ e "Ateu" e "Católico" $($ Mediana $=0,33), r=-0,43$. 
Pairwise Comparisons of Religião (VAR00030) recodificada

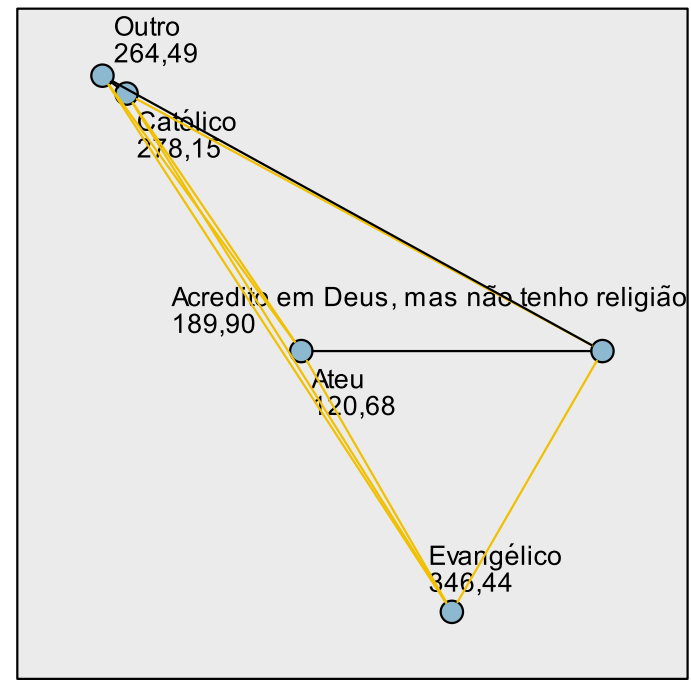

Each node shows the sample average rank of Religião (VAR00030) recodificada.

\begin{tabular}{|lccccc|}
\hline Sample1-Sample2 & $\begin{array}{c}\text { Test } \\
\text { Statistic }\end{array}$ & $\begin{array}{c}\text { Std. } \\
\text { Error }\end{array}$ & $\begin{array}{l}\text { Std. Test } \\
\text { Statistic }\end{array}$ & Sig. & Adj.Sig. \\
\hline $\begin{array}{l}\text { Ateu-Acredito em Deus, mas não } \\
\text { tenho religião }\end{array}$ & 69,220 & 38,900 & 1,779 &, 075 &, 752 \\
\hline Ateu-Outro & $-143,811$ & 43,834 & $-3,281$ &, 001 &, 010 \\
\hline Ateu-Católico & $-157,475$ & 38,740 & $-4,065$ &, 000 &, 000 \\
\hline Ateu-Evangélico & $-225,767$ & 38,674 & $-5,838$ &, 000 &, 000 \\
\hline $\begin{array}{l}\text { Acredito em Deus, mas não } \\
\text { tenho religião-Outro }\end{array}$ & $-74,592$ & 26,798 & $-2,783$ &, 005 &, 054 \\
\hline $\begin{array}{l}\text { Acredito em Deus, mas não } \\
\text { tenho religião-Católico }\end{array}$ & $-88,255$ & 17,248 & $-5,117$ &, 000 &, 000 \\
\hline $\begin{array}{l}\text { Acredito em Deus, mas não } \\
\text { tenho religião-Evangélico }\end{array}$ & $-156,547$ & 17,100 & $-9,155$ &, 000 &, 000 \\
\hline Outro-Católico & 13,663 & 26,565 &, 514 &, 607 & 1,000 \\
\hline $\begin{array}{l}\text { Outro-Evangélico } \\
\text { Católico-Evangélico }\end{array}$ & $-61,956$ & 26,469 & 3,096 &, 002 &, 020 \\
\hline
\end{tabular}

Each row tests the null hypothesis that the Sample 1 and Sample 2 distributions are the same.

Asymptotic significances (2-sided tests) are displayed. The significance level is ,05.

Figura 5.6: Testes post-hoc ao de Kruskal-Wallis para a RO. Acima: Diagrama mostrando as distâncias entre os grupos de religião. Os números representam as médias dos ranks de cada amostra. Abaixo: Em amarelo, estão destacados os cruzamentos diferentes com a significância ajustada. 


\section{2 .4}

\section{Correlações}

A fim de estudar as relações dos fatores acima descritos entre si e com outras variáveis, analisamos a existência ou ausência de correlações ${ }^{55}$ entre eles. Uma vez que os dados aqui analisados são não-paramétricos, o método mais adequado é o $\rho$ (Rô) de Spearman e não o coeficiente Pearson, mais adequado para dados paramétricos. Dessa maneira, foram correlacionadas as variáveis "Fator Aceitação dos Aspectos Científico da Evolução" (AC), "Fator Aceitação da Narrativa Bíblica" (NB), "Entendimento da Evolução", "Religiosidade Intrínseca" (RI), "Religiosidade Organizacional" (RO), "Religiosidade Não Organizacional" (RNO), "idade", "sexo", “cor/raça", "religião", atitudes com relação à disciplina de biologia("gosta de estudar biologia", "faz o dever de casa de biologia", "o professor corrige o dever de casa de biologia") e a "escolaridade máxima dos responsáveis". No caso das variáveis raça e religião, foram criadas variáveis do tipo "dummy" para cada categoria, pois a correlação de Spearman pressupõe que as variáveis são ordinais ${ }^{56}$.No que se refere à variável escolaridade máxima dos responsáveis, utilizamo-la como uma "proxy" (aproximação) para o nível socioeconômico dos estudantes. Essa estratégia foi utilizada baseada em outras pesquisas que apontam a alta correlação entre escolaridade e condição econômica, em especial no Brasil(BARBOSA, 2009; CARVALHO et al., 2012; SOARES, 2004). A descrição completa das variáveis utilizadas para as correlações pode ser encontrada no Apêndice 8.

As correlações entre AC, NB, Entendimento da Evolução, RI, RO e RNO são mostrados na Tabela 5.18 abaixo. $\mathrm{O}$ fator $\mathrm{AC}$ está correlacionado positivamente com o Entendimento da Evolução $(\rho=0,120, p=0,007)$, negativamente com a RI $(\rho=-0,165, p=0,000)$, com a RO $(\rho=-0,179, p=0,000)$ e com a RNO ( $\rho=-0,115, p=0,010)$. Isto significa dizer que quanto mais um estudante aceita os aspectos científicos da teoria evolutiva, mais ele tende a entender a teoria evolutiva, relacionamento que já foi indicado por outras pesquisas(COIMBRA; SILVA, 2007; OLEQUES; BARTHOLOMEI; BOER,

55 Correlação é uma forma de estudar o relacionamento entre duas variáveis. Se elas estão positivamente correlacionadas, quer dizer que quando uma aumenta a outra também o faz e viceversa. Se elas estão negativamente correlacionadas, quer dizer que quando uma aumenta a outra diminui e vice-versa. Se elas não estão correlacionadas, não há qualquer padrão no comportamento de uma com relação à outra.

${ }^{56}$ Isto não faria sentido em nossa pesquisa, uma vez que ao atribuir o valor de 4 para "Católico" e 6 para "Evangélico" estamos apenas representando categorias e não uma escala. 
2011; RUTLEDGE; WARDEN, 1999, 2000). Por outro lado, quanto mais um estudante aceita os aspectos científicos da teoria evolutiva, menor é sua religiosidade intrínseca, sua religiosidade organizacional e sua religiosidade não organizacional. É preciso destacar, porém, que correlação não implica em causalidade. Nesse sentido, não se pode dizer que a religiosidade cause menor aceitação dos aspectos científicos da teoria evolutiva. Por fim, o fator AC não se correlaciona com o fator NB, o que indica que a aceitação dos aspectos científicos da evolução se dá de forma independente da aceitação da narrativa bíblica e viceversa.

\begin{tabular}{|c|c|c|c|c|c|c|c|}
\hline & & Fator AC & Fator NB & $\begin{array}{r}\text { Entend. } \\
\text { evolução }\end{array}$ & RI & RO & RNO \\
\hline \multirow{3}{*}{ Fator AC } & $\rho$ & 1,000 & $-0,015$ & $0,120^{* *}$ & $-0,165^{\star *}$ & $-0,179^{* *}$ & $-0,115^{\star *}$ \\
\hline & $\begin{array}{l}\text { Sig. (2- } \\
\text { tailed) }\end{array}$ & & 0,730 & 0,007 & 0,000 & 0,000 & 0,010 \\
\hline & $\mathrm{N}$ & 508 & 508 & 508 & 497 & 505 & 506 \\
\hline \multirow{3}{*}{ Fator NB } & $\rho$ & & 1,000 & $-0,004$ & $0,416^{* *}$ & $0,367^{* \star}$ & $0,222^{* *}$ \\
\hline & $\begin{array}{l}\text { Sig. (2- } \\
\text { tailed) }\end{array}$ & & & 0,922 & 0,000 & 0,000 & 0,000 \\
\hline & $\mathrm{N}$ & & 508 & 508 & 497 & 505 & 506 \\
\hline \multirow{3}{*}{$\begin{array}{l}\text { Entend. } \\
\text { evolução }\end{array}$} & $\rho$ & & & 1,000 & $-0,022$ & $-0,041$ & 0,047 \\
\hline & $\begin{array}{l}\text { Sig. (2- } \\
\text { tailed) }\end{array}$ & & & & 0,620 & 0,344 & 0,271 \\
\hline & $\mathrm{N}$ & & & 541 & 529 & 538 & 539 \\
\hline \multirow{3}{*}{ RI } & $\rho$ & & & & 1,000 & $0,565^{\star *}$ & $0,441^{* \star}$ \\
\hline & $\begin{array}{l}\text { Sig. (2- } \\
\text { tailed) }\end{array}$ & & & & & 0,000 & 0,000 \\
\hline & $\mathrm{N}$ & & & & 529 & 527 & 528 \\
\hline \multirow{3}{*}{ RO } & $\rho$ & & & & & 1,000 & $0,484^{\star \star}$ \\
\hline & $\begin{array}{l}\text { Sig. (2- } \\
\text { tailed) }\end{array}$ & & & & & & 0,000 \\
\hline & $\mathrm{N}$ & & & & & 538 & 538 \\
\hline \multirow{3}{*}{ RNO } & $\rho$ & & & & & & 1,000 \\
\hline & $\begin{array}{l}\text { Sig. (2- } \\
\text { tailed) }\end{array}$ & & & & & & \\
\hline & $\mathrm{N}$ & & & & & & 539 \\
\hline
\end{tabular}

Tabela 5.18: Correlações ( $\rho$ de Spearman) entre os fatores AC, NB, Entendimento da evolução, RI, RO e RNO.

Com relação ao fator NB, ele se correlaciona positivamente com a RI ( $\rho=$ $0,416, p=0,000)$, a RO $(\rho=0,367, p=0,000)$ e a RNO $(\rho=0,222, p=0,000)$. Tal fato, até certo ponto, parece ser esperado, já que a maior parte dos estudantes pesquisados possui religião e é cristã. Todavia, merece destaque o fato de que a RO tem menor correlação com o NB do que a RI, o que indica que o grau de cometimento ou motivação religiosa individual está mais ligado à aceitação da 
narrativa da Bíblia para a origem e evolução dos seres vivos do que à frequência a templos e reuniões religiosas, onde o estudante estaria, potencialmente, mais exposto a uma doutrina que recuse a visão científica. $\mathrm{O}$ fator $\mathrm{NB}$, entretanto, não está correlacionado ao Entendimento da Evolução, o que indica que aceitar a narrativa bíblica não teria relação com o entendimento da teoria evolutiva neodarwinista. Este parece ser um dado interessante, uma vez que parece indicar que mesmo um estudante que aceita a narrativa bíblica poderia, a princípio, entender a teoria evolutiva, o que temos defendido, apoiado em outros autores, com o objetivo do ensino de evolução.

Já as variáveis ligadas à religiosidade, RI, RO e RNO, estão todos correlacionados positivamente: RI e RO $(\rho=0,565, p=0,000)$, RI e RNO ( $\rho=$ $0,441, p=0,000)$ e RO e RNO $(\rho=0,484, p=0,000)$. Isto significa que quanto maior o escore do estudante em uma dessas dimensões, a tendência é que também seja maior para as outras.

As correlações entre o Fator AC, Fator NB, Entendimento da Evolução, Religiosidade Intrínseca, Religiosidade Organizacional, Religiosidade Não Organizacional e religião, sexo, raça/cor, idade, atitudes com relação ao ensino de biologia e a escolaridade máxima dos responsáveis são apresentadas e discutidas a seguir (Tabelas 5.19 e 5.20).

Na Tabela 5.19, pode-se ver que o Fator AC possui pequena correlação negativa com o fato de o estudante ser evangélico $(-0,122, \mathrm{p}<0,01)$, isto é, se um estudante é evangélico ele tenderia a aceitar menos os aspectos científicos da teoria evolutiva neodarwinista quando comparado aos colegas de outras religiões. Chama atenção que este é o único grupo de religião que possui correlação estatisticamente significativa com este fator. Nesse sentido, não há correlação, por exemplo, entre ser ateu e aceitar os aspectos científicos da teoria evolutiva. Isto pode ser um indício de que a oposição à teoria evolutiva se dê mais em função de um conjunto de crenças específicas de grupos evangélicos, do que propriamente das religiões de uma forma geral. 


\begin{tabular}{|c|c|c|c|c|c|c|c|c|c|c|}
\hline & & Evang & Ateu & ADNR & Catól & Outro & Sexo & Branco & Pardo & Preto \\
\hline \multirow[t]{2}{*}{ AC } & $\rho$ & $-0,122^{* *}$ & 0,079 & 0,024 & 0,034 & 0,058 & $-0,217^{* *}$ & $-0,008$ & 0,026 & $-0,018$ \\
\hline & $\mathrm{N}$ & 505 & 505 & 505 & 505 & 505 & 505 & 503 & 503 & 503 \\
\hline \multirow[t]{2}{*}{ NB } & $\rho$ & $0,369^{* *}$ & $-0,204^{* *}$ & $-0,144^{* *}$ & $-0,150^{* *}$ & 0,002 & $0,127^{* *}$ & 0,021 & $-0,068$ & 0,037 \\
\hline & $\mathrm{N}$ & 505 & 505 & 505 & 505 & 505 & 505 & 503 & 503 & 503 \\
\hline \multirow[t]{2}{*}{$\begin{array}{l}\text { E. } \\
\text { Evo }\end{array}$} & $\rho$ & $-0,013$ & 0,079 & 0,033 & $-0,059$ & 0,016 & $-0,059$ & $0,100^{*}$ & $-0,090^{*}$ & 0,026 \\
\hline & $\mathrm{N}$ & 538 & 538 & 538 & 538 & 538 & 538 & 535 & 535 & 535 \\
\hline \multirow[t]{2}{*}{$\mathbf{R I}$} & $\rho$ & $0,395^{* *}$ & $-0,247^{\star *}$ & $-0,306^{\star *}$ & $-0,009$ & 0,001 & $0,210^{* *}$ & 0,029 & $-0,090^{*}$ & 0,085 \\
\hline & $\mathrm{N}$ & 527 & 527 & 527 & 527 & 527 & 526 & 523 & 523 & 523 \\
\hline \multirow[t]{2}{*}{ RO } & $\rho$ & $0,542^{* *}$ & $-0,209^{* *}$ & $-0,451^{* *}$ & $-0,024$ & $-0,007$ & $0,230^{* *}$ & $-0,028$ & $-0,023$ & 0,063 \\
\hline & $\mathrm{N}$ & 536 & 536 & 536 & 536 & 536 & 535 & 532 & 532 & 532 \\
\hline \multirow[t]{2}{*}{ RNO } & $\rho$ & $0,344^{* *}$ & $-0,177^{* *}$ & $-0,323^{\star *}$ & 0,040 & $-0,009$ & $0,233^{* *}$ & $-0,015$ & 0,010 & 0,022 \\
\hline & $\mathrm{N}$ & 537 & 537 & 537 & 537 & 537 & 536 & 533 & 533 & 533 \\
\hline \multicolumn{11}{|c|}{ **. Correlação é significativa ao nível de 0,01 (2-tailed). } \\
\hline \multicolumn{11}{|c|}{ *. Correlação é significativa ao nível de 0,05 (2-tailed). } \\
\hline
\end{tabular}

Tabela 5.19: Correlações ( $\rho$ de Spearman) entre os índices criados para a pesquisa, religião, sexo e cor dos estudantes.

Esta correlação é, contudo, menor do que a correlação com o sexo (-0,217, $\mathrm{p}<0,01)$. Como atribuímos valor 1 para o sexo feminino e 0 para o masculino, esse dado indica que as meninas participantes da pesquisa tendem a aceitar menos os aspectos científicos da teoria evolutiva do que os meninos. Uma possível razão para isto pode ser encontrada ao analisarmos as correlações entre os fatores de religiosidade e o sexo. As correlações com a RI ( $\rho=0,210, p<0,01)$, RO ( $\rho=$ $0,230, p<0,01)$ e RNO $(\rho=0,233, p<0,01)$, indicam que as meninas tendem a ter índices de religiosidade mais altos dos que os meninos. Se observarmos a Tabela 5.18 , é possível perceber que esses fatores estão negativamente correlacionados com o Fator AC. Esses dados parecem corroborar a análise de Neri e de Melo (2011) de que, tradicionalmente, as mulheres são mais religiosas dos que os homens no Brasil.

Já o fator NB está positivamente correlacionado com o fato de um aluno ser evangélico $(0,369, \mathrm{p}<0,01)$, negativamente com ser ateu $(-0,204, \mathrm{p}<0,01)$, acreditar em Deus, mas não ter religião $(-0,144, \mathrm{p}<0,01)$ e ser católico $(-0,150$, $\mathrm{p}<0,01)$ e não possui correlação com pertencer outra religião. Esses dados sugerem que os estudantes evangélicos possuem crenças sobre a origem dos seres vivos que se aproximam da narrativa bíblica mais do que os outros grupos 
religiosos. É interessante notar, também que a correlação negativa com os estudantes católicos, mostra que, mesmo que a Bíblia seja seu livro sagrado, tende a ser rejeitada quando trata da origem da vida.

Ao contrário do fator $\mathrm{AC}, \mathrm{NB}$ correlaciona-se positivamente com o sexo dos estudantes pesquisados $(0,127, \mathrm{p}<0,01)$, embora em menor intensidade. Isto indica que as meninas tendem a aceitar a narrativa bíblica mais do que os meninos, o que, assim como no caso anterior, pode estar mais ligado ao fato de elas também possuírem maiores índices de religiosidade.

O Entendimento da Teoria Evolutiva mostra pequena correlação positiva com o fato de o estudante ser branco $(0,100, \mathrm{p}<0,05)$ e negativa com o fato do estudante ser pardo $(-0,090, \mathrm{p}<0,05)$, mas não há correlação com o fato do estudante ser preto. Merece destaque que não há correlação significativa entre o entendimento da evolução e a religião dos estudantes nem com o seu sexo. Dessa maneira, há a indicação de que entender a teoria evolutiva seria, em certa medida, independente das crenças religiosas dos estudantes, ao contrário da aceitação de seus aspectos científicos, como vimos anteriormente. No entanto, também discutido anteriormente, o fator AC possui correlação positiva com o entendimento da evolução e com o fato do estudante ser evangélico.

A RI possui correlação positiva com o fato de o estudante ser evangélico $(0,395, \mathrm{p}<0,01)$ e com o sexo $(0,210, \mathrm{p}<0,01)$. Possui correlação negativa com o fato de o estudante ser ateu $(-0,247, \mathrm{p}<0,01)$, acreditar em Deus, mas não ter religião $(-0,306, \mathrm{p}<0,01)$ e ser pardo $(-0,090, \mathrm{p}<0,05)$. Esse resultado aponta no sentido de estudantes evangélicos terem maior envolvimento pessoal com suas crenças religiosas dos que os outros grupos de religião. As mesmas tendências se repetem para a $\mathrm{RO}$ e RNO.

$\mathrm{Na}$ tabela 5.20, são mostradas as demais correlações. Nela é possível perceber que o fator AC se correlaciona positivamente com o fato de o estudante gostar de estudar biologia $(0,162, \mathrm{p}<0,01)$ e não possui correlação com nenhuma das outras variáveis. Isto indicaria que, para os estudantes pesquisados, estar na idade esperada para o primeiro ano do ensino médio, fazer o dever de biologia e o professor corrigi-lo e a escolaridade de seus pais, não influenciam na sua aceitação dos aspectos científicos da teoria evolutiva.

Já o fator NB não está correlacionado a nenhuma dessas variáveis, o que parece apontar no sentido de que a religião - como vimos anteriormente - é o elemento preponderante para a aceitação da narrativa bíblica, não importando se o 
estudante é repetente, se gosta ou não da disciplina, se faz seus deveres e advém de uma família de alto nível de escolaridade.

\begin{tabular}{|c|c|c|c|c|c|c|}
\hline & & $\begin{array}{c}16 \\
\text { anos }\end{array}$ & $\begin{array}{c}\text { Gosta de } \\
\text { estudar bio }\end{array}$ & $\begin{array}{l}\text { Faz dever } \\
\text { de bio }\end{array}$ & $\begin{array}{l}\text { Prof. corrige o } \\
\text { dever de bio }\end{array}$ & $\begin{array}{l}\text { Esc máx dos } \\
\text { responsáveis }\end{array}$ \\
\hline \multirow[t]{2}{*}{$A C$} & $\rho$ & 0,039 & $0,162^{* *}$ & 0,004 & $-0,085$ & 0,025 \\
\hline & $\mathrm{N}$ & 496 & 500 & 508 & 501 & 502 \\
\hline \multirow[t]{2}{*}{ NB } & $\rho$ & 0,019 & $-0,071$ & 0,066 & 0,025 & 0,003 \\
\hline & $\mathrm{N}$ & 496 & 500 & 508 & 501 & 502 \\
\hline \multirow[t]{2}{*}{ E.Evo. } & $\rho$ & $0,095^{*}$ & 0,063 & $0,137^{\star *}$ & $0,128^{* *}$ & $-0,022$ \\
\hline & $\mathrm{N}$ & 529 & 531 & 540 & 533 & 534 \\
\hline \multirow[t]{2}{*}{ RI } & $\rho$ & $-0,014$ & 0,013 & 0,072 & 0,040 & 0,033 \\
\hline & $\mathrm{N}$ & 518 & 519 & 528 & 521 & 522 \\
\hline \multirow[t]{2}{*}{ RO } & $\rho$ & $0,097^{*}$ & 0,017 & 0,025 & 0,004 & $0,105^{\star}$ \\
\hline & $\mathrm{N}$ & 527 & 528 & 537 & 530 & 531 \\
\hline \multirow[t]{2}{*}{ RNO } & $\rho$ & $0,090^{*}$ & $0,092^{*}$ & 0,033 & 0,014 & 0,007 \\
\hline & $\mathrm{N}$ & 528 & 529 & 538 & 531 & 532 \\
\hline
\end{tabular}

Tabela 5.20: Correlações ( $\rho$ de Spearman) entre os índices criados para a pesquisa, idade, cidade onde mora, gosta de estudar de biologia, faz dever de casa de biologia, professore corrige dever de biologia, estudou somente em escola pública desde o $6^{\circ}$ ano e escolaridade máxima dos responsáveis.

Para o entendimento da teoria evolutiva neodarwinista, a situação é diferente. Houve pequena correlação positiva entre esta variável e o fato de o estudante ter 16 anos ou menos $(0,095, \mathrm{p}<0,05)$, o que indica que estudantes repetentes teriam leve tendência a entender menos a evolução dos que estão na idade esperada. Houve, ainda, correlação positiva com fazer o dever de casa de biologia $(0,137, \mathrm{p}<0,01)$ e com o professor corrigi-lo $(0,128, \mathrm{p}<0,01)$, o que, em certa medida, seria esperado. Todavia, não houve correlação com o gosto do estudante pela disciplina, nem com a escolaridade dos pais. Este último resultado chama atenção, pois a literatura na área aponta a forte influência da escolaridade dos responsáveis e o nível socioeconômico dos estudantes sobre seu desempenho escolar (RIBEIRO, 2011). Uma possibilidade é que nosso estudo esteja tratando de um conjunto de questões muito específico (todas relacionadas à evolução) em duas escolas, o que poderia fugir da tendência descrita por pesquisas anteriores. É 
possível, ainda, que o instrumento por nós utilizado não seja suficientemente adequado e, por isso, encontramos um resultado distinto.

Quanto aos índices de religiosidade, a RI não se correlacionou com nenhuma das variáveis selecionadas. Já a RO correlaciona-se positivamente com o fato de o estudante ter 16 anos ou menos $(0,097, \mathrm{p}<0,05)$ e com a escolaridade dos responsáveis $(0,105, \mathrm{p}<0,05)$ o que indica que, no caso dos estudantes de nossa pesquisa, quanto maior a escolaridade dos responsáveis, maior a frequência a encontros religiosos. Por fim, a RNO correlaciona-se positivamente com a idade dos estudantes $(0,090, \mathrm{p}<0,05)$ e com o gosto pela disciplina de biologia $(0,092$, $\mathrm{p}<0,05)$. Cabe destacar que essas correlações foram pequenas e que não são sinônimo de causalidade.

\section{3}

\section{Síntese}

Neste capítulo, procuramos apresentar e analisar as concepções dos estudantes participantes da pesquisa sobre criacionismo, evolução e a abordagem desses temas em sala de aula. Vimos que há diversidade entre os estudantes entrevistados, mesmo entre aqueles que seguem a mesma religião. Além disso, é possível perceber muitas dúvidas com relação às suas próprias visões de mundo, principalmente com relação a tentativas de conciliar conhecimentos científicos e religiosos. Com relação aos dados quantitativos, a aceitação da teoria evolutiva envolve dois aspectos principais: a aceitação de seus fatores científicos e a aceitação da narrativa bíblica. Percebemos, também, que os estudantes evangélicos são os mais resistentes à evolução e manifestam maior religiosidade do que os demais.

No próximo capítulo, exploraremos as dinâmicas desenvolvidas em sala de aula, utilizando, principalmente, os dados relatados no caderno de campo. Procuraremos analisar as aulas de cada de professor, priorizando os momentos em que evolução e criacionismo foram discutidos. Na medida do possível, retomaremos a discussão de dados já realizadas neste capítulo e nos anteriores, a fim de cruzá-los e aprofundá-los. 
6.

\section{As relações entre religião, ciência, criacionismo e evolução em sala de aula}

Neste capítulo, apresentaremos e analisaremos os registros de nossas observações em sala de aula relacionadas ao relacionamento de religião e ciência e criacionismo e evolução. Procuraremos discutir não só os episódios observados em si, mas também as possíveis conexões entre eles e as declarações dos(as) docentes e discentes em suas entrevistas. Nesse sentido, buscaremos explorar os diferentes episódios sob a perspectiva de professores, estudantes e a nossa própria, utilizando para isto o modelo de espaço de busca desenvolvido no capítulo 2 (a lista de temas e códigos utilizados na análise podem ser vistos no Apêndice 9).

É importante ressaltar que, de acordo com o currículo mínimo, estes tópicos deveriam ser discutidos, em certa medida, no primeiro bimestre, dado que este documento traz a seguinte orientação "Reconhecer a existência de diferentes explicações para a origem do universo, da Terra e da vida, bem como relacionálas a concepções religiosas, mitológicas e científicas de épocas distintas" (Anexo 1), já destacada anteriormente. Além deste momento, o terceiro bimestre, no qual evolução é o foco apontado pelo documento, essas temáticas, com frequência, voltaram à sala de aula, principalmente ao se contrastar o criacionismo com as teorias evolutivas de Lamarck e Darwin. Sendo assim, alguns professores/as como P1, por exemplo - desenvolveram-nas mais a fundo no terceiro bimestre, enquanto outros/as - como P2 - o fizeram no primeiro.

Queremos destacar, ainda, que a análise desses episódios não visa o julgamento das aulas e dos professores em "bons" ou "ruins". O lugar de pesquisador no ambiente da sala de aula, além do fato de estar munido de referenciais teóricos construídos antes, durante e depois das observações, o coloca em uma posição privilegiada para realizar um tipo específico de análise. Intencionamos, primordialmente, explorar essas situações a fim de discutir alguns elementos para o ensino de biologia e, mais especificamente, de evolução e origem da vida, os quais podem vir a ser desenvolvidos almejando-se a compreensão de conceitos científicos respeitando-se a crença dos estudantes. 
Reconhecemos também que nossa presença, ainda que não estivéssemos interagindo diretamente com os sujeitos da pesquisa, não era ignorada por professores e estudantes. Em todos os relatos aqui descritos e analisados, é preciso considerar que o(a) professor(a) podia estar se sentindo avaliado pelo pesquisador e ter a sensação de que ele/ela deveria falar ou agir da maneira "certa" ou do jeito que "esperávamos". Assim, é possível e provável que, sem a presença do pesquisador, algumas situações se desenvolvessem de forma distinta.

Optamos por apresentar e analisar as aulas de cada professor separadamente, pois isto facilitaria o cruzamento dos dados empíricos, ajudaria a construir mais claramente o contexto de cada caso e as respectivas representações do modelo de espaço de busca. Assim, procuramos articular as concepções dos docentes e dos discentes, discutidas nos capítulos anteriores, juntamente com as observações. É importante ressaltar que os modelos aqui representados referem-se apenas ao ensino da origem e evolução dos seres vivos e não todas as aulas e estratégias pedagógicas de cada professor.

\section{1}

\section{Aulas de P1: entre comprovações e céus}

O professor P1 trabalhava no Colégio Guarani nas turmas 1008 (a qual observamos), 1024 e 1025. Como descrevemos no capítulo 4, ele já teve várias religiões, mas hoje declara não pertencer a mais nenhuma. Suas concepções indicam uma separação clara entre evolução e criacionismo, estando a primeira mais próxima da realidade e o segundo restrito à leitura literal da Bíblia. A seguir, descrevemos e discutimos alguns eventos ocorridos em suas aulas, em especial uma discussão que teve com uma estudante evangélica em uma aula sobre evolução.

No primeiro dia letivo do ano, perguntei a P1 se ele tem ou se já havia tido conflitos em sala de aula quando ensinava evolução. Ele disse que sim, mas que ia "levando" e não se aprofundava muito. Contudo, ao se referir à visão criacionista, disse que procurava deixar claro "que aquilo ali não existe". Sua afirmação nos parece ser reflexo de suas concepções de evolução e criacionismo, expressas em sua entrevista e discutidas anteriormente. Enquanto, segundo o professor, a primeira se aproxima da verdade, o segundo se distancia dela. Não há, para ele, 
possibilidade conciliação entre ambos e isso se manifesta em suas aulas todas as vezes em que este tema emerge.

A única vez em que tratou do criacionismo no primeiro bimestre, foi na última aula antes da prova, durante a aplicação de exercícios de revisão copiados no quadro, a partir do livro didático. A última questão era de múltipla escolha e pedia para que fosse assinalada a alternativa que indicava que ideia o experimento de Miller ajudou a reforçar. Stanley Miller mostrou em laboratório que era possível a formação de aminoácidos em condições semelhantes à da atmosfera primitiva da Terra. Uma das alternativas do exercício dizia que a experiência teria indicado que a vida na Terra "foi criada por Deus exatamente como está descrito no Gênese, primeiro livro da Bíblia". Um pequeno grupo de alunos sentados próximos à mesa do professor abordou o assunto do criacionismo de forma aparentemente cordial e sem conflitos evidentes à nossa observação. Durante essa conversa, conseguimos ouvir P1 declarar aos alunos que "Nós viemos de outros seres vivos. Isso é demonstrado. São várias características, não só morfológicas, mas também genéticas. Para a ciência, Adão e Eva, aquele momento não é realidade. Criacionismo é uma questão religiosa".

$\mathrm{Na}$ declaração anterior, é possível novamente perceber a visão do professor de que há uma separação muito clara entre evolução e criacionismo, em que a primeira é suportada por várias evidências e o último não tem sustentação e se restringe a esfera religiosa. Ainda que esta concepção esteja em consonância com pesquisadores da área de ensino de evolução que frisam a necessidade de se discutir as diferenças entre as ideias religiosas e científicas, explicitando-se as razões para se defender a teoria evolutiva (SMITH; SIEGEL, 2004), o uso do termo "demonstrado" dá margem a interpretações cientificistas de que a ciência não seria contestável.

Se no momento descrito acima, as afirmações não foram ouvidas por mais do que um pequeno grupo de alunos e não pareceram gerar maior impacto sobre eles, um episódio ocorrido ao início do terceiro bimestre ocorreu de forma bastante distinta. Ao longo da aula, P1 ditava alguns conteúdos para que os estudantes os anotassem em seus cadernos. Um dos trechos ditados foi o seguinte:

Descreva a teoria do criacionismo.

Teoria segundo a qual todas as espécies vivas foram criadas por ato divino, tal e qual se apresentam hoje. De acordo com a teoria criacionista, o número de espécies foi determinado por Deus no início da criação. 
Até meados do século XIX predominou o criacionismo e depois ganhou força a ideia de que os seres vivos se modificam ao longo do tempo. Estudos revelaram a existência de restos e vestígios de seres extintos, os fósseis, lançando dúvidas sobre o dogma da imutabilidade das espécies biológicas.

Qual a diferença fundamental entre criacionismo e evolucionismo? $O$ criacionismo não é científico, pois tem como base um conjunto de dogmas, ou seja, verdades consideradas inquestionáveis, que não admitem outras interpretações. A visão científica, por outro lado, parte do princípio de que não há verdades inquestionáveis e que sempre existe a possibilidade de uma explicação considerada verdadeira estar errada.

No primeiro parágrafo ditado, o professor define o criacionismo como sendo fruto da atuação direta de Deus e tendo caráter fixista, isto é, as espécies de seres vivos seriam fixas e não sofreriam modificações ao longo dos anos. Tal visão reflete a concepção pessoal do professor sobre o criacionismo, como discutido no capítulo 4, e reforça a oposição entre ciência e religião. No segundo parágrafo, afirma-se que o criacionismo - aqui referido sem o conceito de teoria foi predominante até o século XIX, quando foram descobertos vestígios e fósseis que fizeram com que esta ideia fosse questionada ${ }^{57}$. Já no terceiro parágrafo do ditado, P1 aborda mais diretamente a diferença entre o criacionismo, enquanto ideia religiosa, e a teoria evolutiva, enquanto ideia científica. Ele afirma que o criacionismo não pode ser considerado científico, pois se baseia em dogmas e não pode ser questionado. Já a visão científica é passível de questionamentos, uma vez que não seria possível afirmar, sem dúvida, que seria verdade.

A concepção de ciência apresentada neste último parágrafo se opõe àquela que interpretamos acima, a partir da expressão "demonstrado". No entanto, em sua entrevista, P1 afirmou que precisa falar de criacionismo e mostrar que este não era verdade, para falar de evolução - de onde se deduz que a evolução seria considerada a verdade. Tal concepção fica ainda mais evidente ao analisarmos, mais à frente, os momentos seguintes da aula.

Chama atenção que o professor use o conceito de teoria para se referir ao criacionismo no primeiro parágrafo. Assim como discutimos anteriormente para o caso de outros professores (como P2, por exemplo), esse uso nos parece problemático, tendo em vista que pode sugerir um caráter científico às ideias criacionistas ou, no mínimo, um uso indiscriminado do conceito de teoria. Uma interpretação alternativa poderia ser que o professor esteja se referindo às ideias

\footnotetext{
${ }^{57} \operatorname{Mayr}(1982)$ afirma que os primeiros registros de descoberta de fósseis remontam à Grécia antiga e não ao século XIX. Reconhecemos, contudo, que tal informação não compromete o sentido pretendido pelo professor de novas interpretações sendo construídas nesse período histórico.
} 
que precederam às teorias evolutivas que não incluíam a atuação de Deus, isto é, quando o criacionismo era considerado uma explicação plausível por cientistas. No entanto, a análise do terceiro parágrafo nos indica que, de acordo com P1, o criacionismo não poderia ser considerado científico. Sendo assim, há certa incoerência na forma de lidar com a categoria de teoria, a qual deixa de assumir um caráter estritamente científico e é usada no sentido de uma ideia, ligada à ciência ou não.

Após ditar esse trecho, P1 começou a explicar o que é um dogma, dizendo, com veemência, que é uma afirmação que não é comprovada, nem científica na qual se acredita porque outra pessoa lhe disse. Como exemplo, ele diz que há quem acredite em Adão e Eva. Ao fazer essa afirmação, A12 (evangélica pentecostal) respondeu que acreditava nestes dois personagens bíblicos, ao passo que P1 replicou afirmando incisivamente que não havia comprovação disso e que o mais importante era o conteúdo que estava ensinando e não a religião de cada um. Em seguida, o docente disse "Eu não acredito em Adão e Eva. O Deus que eu acredito não interessa eu falar aqui para vocês. Isso é uma coisa de cada um". Complementou, dizendo que para o criacionismo as espécies são imutáveis - o que não seria verdade - e que a visão evolucionista é que seria a científica.

A estudante A12 e alguns colegas sentados próximos à sua carteira, pelas suas expressões faciais e corporais, pareceram constrangidos após essas afirmações de P1. O professor continuou discorrendo sobre o criacionismo e a existência de Deus, dessa vez de forma jocosa: "Dizem que Deus está entre as nuvens. Aí você pega um avião. Aí você passa de avião e não vê nada”. A expressão de A12 e de seus pares mais próximos passou, então, ao estranhamento. A aluna contestou a alegação do professor, afirmando que, na verdade, existem vários céus e, por isso, não se veria Deus ao se voar de avião. P1 não levou a opinião da estudante em consideração e esta, juntamente com colegas, pediu ao professor que mudasse de assunto. O docente, então, lhes disse que a aula naquele dia era justamente sobre tal assunto e que para que ele acreditasse no criacionismo "basta provar, basta comprovar". Os alunos, incluindo A12, optaram por silenciarem-se e P1 continuou a aula, ainda sob certo clima de constrangimento.

Ao final da aula, A2 (católico) foi à mesa do professor para explicar-lhe que o céu em que acreditava era transcendental e criticar o tom de deboche de P1. 
Em sua entrevista, A2 declarou que houve um mal-estar na turma. Quando perguntado por que, ele afirmou:

A2: Porque o professor disse que... 'Todo mundo fala que Deus está no céu... Aí você pega o avião e só vê nuvem '[risos] e aí as meninas foram começar a discutir... Eu até cheguei no professor e comecei a falar assim: 'ok, pode estar mostrando um olhar seu e tal, mas eu acho que Deus transcende, sabe? '[...] É um céu que nós, católicos, e talvez os evangélicos, eles criam, mas não é o céu propriamente dito. É um céu espiritual, alguns estão lá ao lado de Deus... Não um céu que está azul hoje no Rio de Janeiro, um céu de brigadeiro... Não. Por isso que eu disse a ele, que achava e tenho certeza, que Deus transcende toda essa visão.

P: Como você se sentiu nessa aula?

A2: Eu não me senti chateado. A única coisa que falei pra ele foi: 'Não sei se você tá mostrando seu olhar, pode ser uma coisa meio debochada, mas eu acho que Deus é uma coisa transcendental acima de tudo'.

Atitude semelhante teve A12, que também tentou esclarecer para o professor o que ela acreditava. P1, entretanto, olhou em minha direção (pesquisador), deu de ombros, um sorriso de canto de boca, soltando ar pelo nariz rapidamente e um leve movimento de cabeça de um lado para outro, demonstrando não levar a sério o que os alunos estavam lhe falando.

Durante sua entrevista, realizada posteriormente ao episódio descrito, A12 falou um pouco mais sobre sua crença na Bíblia, Adão e Eva e em vários céus:

P: Como você pensa que a vida surgiu no nosso planeta?

A12: Eu penso que foi como Gênesis diz... Que Deus criou o mundo em seis dias e no sétimo Ele descansou.

P: E o ser humano, homem e mulher... Como é que surgiu?

A12: Foi Adão e Eva. O homem do barro e a mulher da costela.

P: Eu lembro que na última aula de biologia, o professor estava falando de evolução $e$ aí você estava discordando um pouco do que ele estava falando...

A12: Porque na Bíblia não diz que não existiu dinossauros. Aí ele falou dos animais que foram extintos. Na Bíblia não diz que nenhum animal é eterno. Na Bíblia não está lá, tipo, todas as espécies que Deus criou, então eu achei que foi... Eu discordei um pouco. Muitas vezes as pessoas falam: 'ah, não tem na Bíblia'. Às vezes não tem assim, explícito. Mas pode estar implícito.

P: Eu me lembro que você falou que existiam vários céus...

A12: Ah sim... Porque o pessoal acha que o céu é acima das nuvens. Ai fala: 'ah, quando eu viajei de avião eu não vi Deus'. Não, na verdade existem vários céus... É porque eu ainda tenho que estudar isso em teologia, mais tarde eu estudarei. Meu pastor disse que existem vários céus, não é só chegar nas nuvens e Deus vai estar lá. É um céu... Eu não sei, não tenho certeza, mas eu acho que é um céu que está assim... Além da galáxia, entendeu? Não é um céu que a gente vai ver... Viajar de avião e... 'ah, vou ver Deus'. Ai o professor ficou até falando 'ah, vai ver nuvem' [muda o tom da voz, imitando o professor de maneira jocosa].

No trecho acima, a estudante diz que acredita na narrativa do Gênesis sobre a origem da Terra e dos seres humanos de maneira literal, remetendo-se aos dias da criação, ao descanso de Deus, a formação de Adão a partir do barro e de Eva a partir de sua costela. No entanto, quando aborda a existência dos dinossauros e do céu, no sentido de Paraíso, ela utiliza uma abordagem não-literal 
do livro sagrado dos cristãos, afirmando que nem todas as mensagens bíblicas estão explícitas. Ela argumenta que na Bíblia não estão listadas todas as espécies criadas por Deus, nem que elas seriam eternas. Além disso, ancorando-se nos ensinamentos do pastor de sua igreja, diz que Deus estaria em um céu "além da galáxia”, o que, embora possa não fazer sentido de um ponto de vista científico, reforça o significado de transcendência do qual a estudante parece se aproximar quando afirma que "não é só chegar nas nuvens e Deus vai estar lá”. Por fim, percebe-se que a atitude do professor lhe causou desconforto. Ao repetir a fala do professor em tom jocoso, ela intensifica a crítica que fez ao longo de sua resposta. No momento subsequente de seu relato, ela detalha como se sentiu naquele momento:

P: Como é que você se sentiu quando o professor estava falando isso?

A12: Eu não gosto de ficar falando porque... Na verdade, religião é um assunto muito delicado de se tratar porque cada um tem a sua e, às vezes, a gente fala de uma maneira que a nossa é a melhor e tal... Eu entendo que cada um pode seguir a religião que quiser, mas eu não prefiro ficar falando, sabe... Ficar quieta também porque... Eu sou muito expressiva e tal, mas eu posso falar alguma besteira e tal e até pra prejudicar minha religião mesmo.

P: Mesmo quando o professor fala alguma coisa que você não concorda...

A12: Eu entendo. É matéria e eu preciso estudar aquilo, mas isso não influencia na minha religião, entendeu?

A estudante inicia esse trecho dizendo que não gosta de discutir sobre religião porque seria um assunto delicado e não quer sugerir que sua religião seja melhor do que a de outras pessoas, o que poderia vir a prejudicar a imagem de sua própria crença (A12 se declarou evangélica, vide Apêndice 6). Quando questionada se mantém tal pensamento e atitude quando o professor fala sobre algo com o qual não concorda, ela afirma que tal tópico faz parte do conteúdo e que ela precisa estudá-lo. Contudo, isto não significa que sua crença religiosa seja influenciada.

É interessante notar que a fala de A12 indica a existência de tensões em discussões relacionadas à religião. Apesar de a estudante ter exposto sua opinião durante a aula, ela mesma afirma que não gosta de falar sobre isso, o que sugere que esta atitude não foi facilmente tomada. Finalmente, ao afirmar que estuda a matéria, mas que essa não muda a maneira como vê sua crença, ela demonstra certa aproximação do que Cobern (1996) chama de apartheid cognitivo. Ela cria barreiras que isolam esses conteúdos de suas crenças pessoais, a fim de cumprir, de certa maneira, com seu papel de aluna - quando diz "eu preciso estudar 
aquilo" (grifos nossos) - mas sua crença não é afetada. É preciso reconhecer, contudo, que não possuímos dados suficientes para avaliar se ou até que ponto suas crenças não fora em afetadas pelas aulas. Entretanto, a atitude ativa da aluna em resistir a possíveis mudanças de pensamento, difere da de outros sujeitos da pesquisa, como veremos mais adiante, que demonstram certa abertura à visão científica.

Entrevistamos P1 também após esta aula. Em sua fala ele evita comentar mais diretamente os argumentos da estudante e frisa que é preciso cuidado ao se tratar de assuntos controversos com adolescentes:

P: E esse conflito[pessoal] que você falou que você passou? Você acha que isso afeta suas aulas? Afetou suas aulas de alguma maneira?

P1: [hesita] É, eu fico com receio de tentar provocar uma coisa, cabeça de adolescente eu não sei... [...] Há tantas outras coisas, tantas dificuldades hoje em dia que não eram as minhas... [...] Eu não posso chegar aqui e vir taxativo: 'isso não existe'. Eu quero cumprir o conteúdo, quero explicar o conteúdo. Agora, o que você tem que pensar a partir dele, não tenho nada a ver com isso, não quero ter essa responsabilidade. Eu não vou dizer a ninguém 'eu sou ateu, você tem que ser ateu porque Deus não existe'. Em hipótese alguma eu vou fazer isso. [...]

$P: E$ você já viu conflito em sala de aula, quando foi ensinar evolução?

P1: Tem.

P: Como foi essa situação?

P1: Faz cara feia quando eu falo certas coisas. Mas eu desfaço isso colocando, aquela coisa que eu falei, dos argumentos.[...] Eles não têm como refletir do mesmo jeito que eu, eu não posso jogar uma coisa, então eu fico com cuidado. Então, eu vou chegar lá e vou dizer 'estou cumprindo o conteúdo', isso aqui é o conteúdo. Aí eu vou forte. O importante é a afetividade, o afeto, a aceitação, o ambiente, as pessoas que estão ao seu lado, seja em qualquer lugar, seja em um ambiente religioso ou não.

[Interrupção por um colega professor na porta da sala]

P: Foi na ultima aula isso?

P1: Acho que foi na última, na última eu fui mais sistemático, na outra eu falei mais, acho que acabei falando mais. Mas aquele dia também teve, não teve?

P: Também teve. Uma menina que falou na questão de ter vários céus, e tal.

P1: Também, também. Tinha falado de outras coisas, sempre falo que não é só isso, não pode fixar em uma coisa assim, justamente porque eu não imagino como seja a reflexão para um adolescente, e eles são radicais, levam a coisa muito ao pé da letra, e essa confiança em mim pode produzir uma coisa que eu não gostaria. Eu acho que tem que respeitar isso, tem que ter cuidado.

$\mathrm{Na}$ fala de P1é recorrente a ideia de um receio com o que os estudantes podem vir a pensar do que ele está falando em sala. Ele afirma que não poder ser taxativo de dizer que Deus não existe, defendendo uma postura de ater-se ao conteúdo a ser ensinado. Ele acrescenta que é importante demonstrar também afetividade pelos estudantes e aceitar as pessoas que estão ao seu redor independente de ser um ambiente religioso. Como destacamos acima, ainda que lembrado pelo entrevistador, ele não comenta especificamente o caso de A12, 
optando por ressaltar seu receio em relação às opiniões dos estudantes e reafirmar que é necessário respeitá-las.

No caso acima, é possível perceber que P1 reduz o conhecimento produzido pelas religiões a dogmas, dos quais os fiéis seriam convencidos por outrem a acreditar. Nesse sentido, o professor não leva em consideração que o conhecimento religioso seja interpretado de diferentes maneiras dentro de uma mesma tradição religiosa e que a relação do fiel com esta não é apenas passiva, mas envolve reflexão que traz sentido à sua vida (GEERTZ, 2001). Ao utilizar o exemplo de Adão e Eva e dizer que há quem acredite nessas personagens bíblicas, sugere que tal crença não faz sentido, o que vai de encontro ao que professor declarou em sua entrevista e provoca a manifestação da aluna A12 e o comentário de A2 ao final da aula. Na resposta do professor, pode se identificar uma justificativa para rejeitar o criacionismo - o fato de não ser científico - e duas para rejeitar a sua discussão em sala de aula: (i) o assunto principal da aula é o conteúdo a ser ensinado (ponto também defendido em sua entrevista) e (ii) a religião dos atores escolares ali presentes não importa. Ao insinuar que crença na existência de Adão e Eva não faz sentido, o professor utilizou de sua autoridade em sala de aula para avançar sobre uma área que está fora do escopo de atuação da ciência - a validade da crença de outrem (COBERN, 2000; SMITH; SIEGEL, 2004). Ao ser questionado pela aluna, utiliza sua autoridade novamente para voltar à área da ciência, alegando que tal assunto não fazia parte da atuação da ciência.

Esta dinâmica se repete quando P1 usa o exemplo do avião atravessando o céu e que, uma vez que não se vê Deus, poder-se-ia deduzir que Deus não existe. $\mathrm{O}$ professor ignora o fato de que a afirmação de que Deus estaria no céu não possui, necessariamente, um significado literal, mas também metafórico. Além disso, considera a observação direta como mecanismo infalível para a construção do conhecimento, o que é problemático, tendo em vista que nossa percepção do mundo pode nos levar a conclusões falsas (PRITCHARD, 2006). A frase causa estranheza a A12, que expõe sua visão de que, na realidade seriam vários céus, argumento ignorado pelo professor. Este, por sua vez, declara que para que acredite no criacionismo, basta que o comprovem. Isso implica que, uma vez que ele acredita na evolução, é porque entende que ela foi comprovada. Em conjunto com a ênfase dada ao papel da observação, essa noção de comprovação como 
parte do pensamento científico, faz com que P1 se aproxime de uma concepção cientificista da realidade. Em outras palavras, a visão de mundo da ciência seria mais válida do que qualquer outra. P1 volta a demonstrar tal pensamento quando A12 e A2 vão à sua mesa ao final da aula para tentarem explicar-lhe suas crenças. Ele volta a ignora-los, dessa vez de forma ainda mais incisiva, através de sua expressão corporal. Ao desrespeitar a crença da estudante e usar de sua autoridade para sustentar seu posicionamento, P1 viola os mínimos éticos (CORTINA, 1996, 2008) necessários para o desenvolvimento de um ensino. Neste caso, o ensino de origem e evolução da vida voltados para o entendimento dos conhecimentos científicos e não para a mudança de crença. Impondo seu posicionamento aos alunos, não valoriza a tolerância ética e epistemológica como um mínimo ético exigível nas práticas pedagógicas(ANDRADE, 2009).

Cabe destacar que, com isso, não queremos afirmar que a existência de Adão e Eva e de Deus deva ser diretamente acatada pelo professor, simplesmente porque a aluna neles acredita. Entendemos, tal qual Smith e Siegel (2004), que o professor de biologia deva discutir as razões para que a ciência acredite que a teoria da evolução é válida e que uma crença, embora seja uma condição para o conhecimento, não é suficiente para construí-lo. Nesse sentido, o professor poderia explicar sobre a evolução humana e os estudos sobre o registro fóssil, os quais indicam que o ser humano teve uma origem diferente e mais antiga do que a leitura literal do Gênesis relata. Ainda assim, seria necessário ao professor reconhecer, como aponta Cobern (2000), que situações como essa envolvem pensamentos que vão além do escopo da ciência. Isto é, o fato de Deus existir ou não, possui muitos outros desdobramentos para além da descrição do mundo natural, tais como o sentido da vida e do pós-vida, a moral, a relação com outras pessoas etc. Desqualificar a crença dos estudantes não parece facilitar o entendimento da teoria evolutiva. Pelo contrário, parece estimular o processo de apartheid cognitivo (COBERN, 1996), reforçando a perspectiva de que a teoria evolutiva é uma ameaça à sua fé.

A Figura 6.1 mostra o modelo de espaço de busca para o caso de P1. Seus pontos de vista são semelhantes em sua entrevista e em sua sala de aula. Entretanto, como ele desvalorizou a crença da aluna, não há sobreposição de entendimento comum. Uma vez que ele não esteve aberto às ideias da estudante, não foi possível desenvolver um espaço de busca em que um pudesse se esforçar 
para compreender a visão de mundo do outro. É importante perceber que P1, ao argumentar que a existência Adão e Eva não é científica nem comprovada, sugere que o que não é científico seja falso, o que causa incômodo na estudante, uma vez que tais elementos fazem parte de sua crença e de sua visão de mundo.

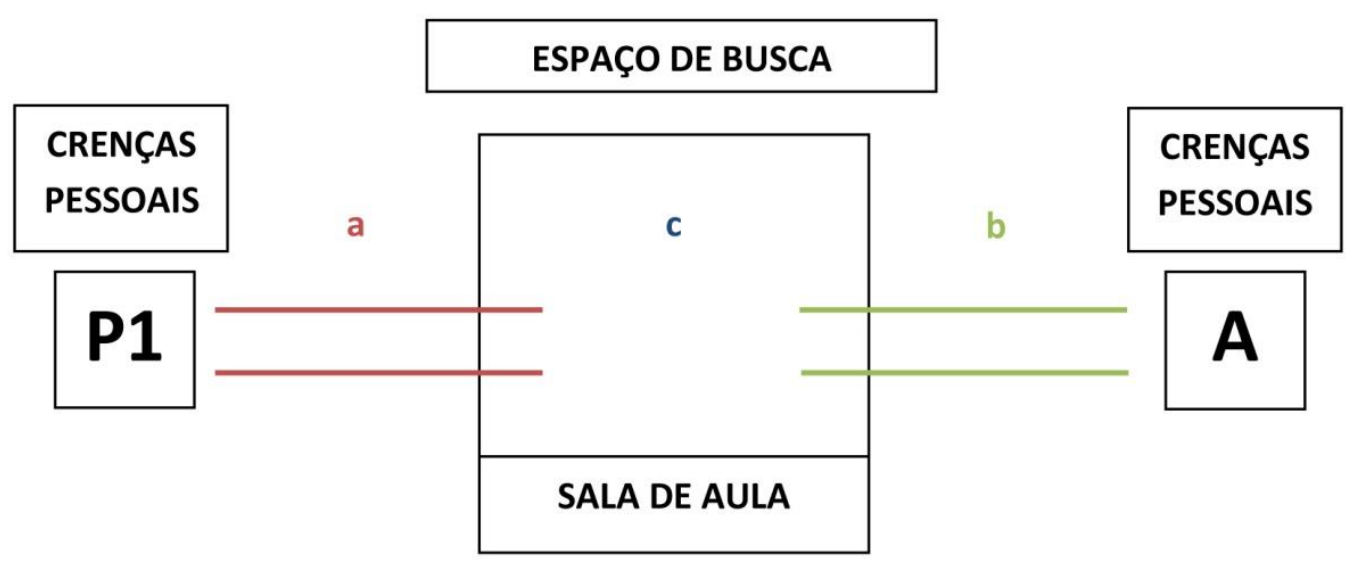

Figura 6.1: Modelo do espaço de busca para P1.

Além disso, ao associar ciência à comprovação, dá sinais de que acredita que a ciência possa gerar conhecimentos capazes de serem provados e, por consequência, verdadeiros e impossíveis de serem negados. Dessa maneira, implicitamente, afirma que a ciência consegue identificar o mundo como ele realmente é, e a religião não. Nesse sentido, suas estratégias pedagógicas e retóricas em sala de aula se correlacionam com suas concepções acerca de evolução e criacionismo. Assim como ele os considera como conceitos plenamente distintos, sendo um verdadeiro e o outro não, ele também argumenta desta forma durante sua lição. O não-desenvolvimento de um espaço de busca decorre da não-abertura à visão da aluna, diversa da sua.

\section{2}

\section{Aulas de P2: tentativas de diálogo e receios}

A professora P2 trabalhava no Colégio Guarani, é católica não-praticante e procura conciliar crenças religiosas com conhecimentos em biologia. Ela afirma, como discutimos no capítulo 4 , que acredita em uma força superior que atuou na criação do universo e da vida. Todavia, ela também reconhece que possui muitas dúvidas sobre a origem da vida e que isso dificulta suas explicações para os 
alunos. Nas aulas que observamos, percebemos que há indícios de que a autocrítica da professora faz sentido, uma vez que ela estimula que os estudantes exponham suas opiniões, porém não aprofunda a discussão sobre as razões que teriam para ter essas crenças. Sua fala, silêncios e expressão corporal pareciam demonstrar certo receio em realizar essa tarefa. Além disso, é preciso reconhecer que a presença de um pesquisador em sala também provocava certo distúrbio para a professora. Certa vez, após uma aula, P2 disse que insistiu para que os alunos falassem, para que eu tivesse 'muitas páginas para escrever na tese, mas eles não contribuíram', o que demonstra que estava atenta e preocupada com a presença do pesquisador e com o nosso tema de pesquisa.

Observamos as três turmas em que a docente dava aulas: 1016, $1017 \mathrm{e}$ 1018. Nas aulas sobre origem da vida e evolução, P2 adotava a estratégia de perguntar aos estudantes como achavam que a vida tinha surgido para depois se aprofundar sobre o conteúdo. Na turma 1018, poucos alunos respondiam a suas perguntas e poucos diálogos foram estabelecidos. Uma possível explicação é de que este assunto, por ser controverso, fazia com que os alunos se sentissem pouco à vontade para responder. Outro fator que poderia contribuir para este comportamento seria o fato de o tópico origem da vida ser o primeiro a ser abordado no ano letivo e, talvez, os estudantes ainda estivessem acanhados por não conhecerem a professora e seus colegas. Entretanto, tais explicações nos parecem limitadas, dado que este padrão de pouca interação entre turma e docente se repetiu ao longo de todo o ano, independente do assunto abordado. Nesse sentido, é mais provável que outros fatores, para os quais não possuímos dados suficientes para fazer afirmações definitivas, tenham influenciado o comportamento dos estudantes.

Já nas turmas 1016 e 1017, os estudantes participavam mais ativamente, respondendo com suas opiniões. No entanto, poucas vezes o diálogo foi aprofundado. Na maior parte das ocasiões, as respostas dos alunos eram ouvidas por P2, mas eram tratadas como uma coleção de pensamentos soltos, às vezes, relacionados pela professora genericamente ao criacionismo, o qual ela também abordava.

Na segunda aula na turma 1016 no primeiro bimestre, P2 perguntou em direção a toda a turma, como achavam que a vida tinha surgido. Vários estudantes responderam prontamente: 
- "Deus"

- "Para mim foi Deus"

- "Poeira estelar"

- "Explosão”

- "Big Bang"

- "Meteoro"

- "Quatro gases da atmosfera"

- "Terra primitiva"

É possível perceber que tanto há respostas que se aproximam de conceitos religiosos ("Deus", "Para mim foi Deus"), quanto aquelas que se relacionam mais diretamente com conceitos científicos ("Poeira estelar", "Explosão", "Big Bang", "Meteoro", "Quatro gases da atmosfera", "Terra primitiva"). Nota-se, também, que a ideia de origem da vida remeteu alguns estudantes também às origens do universo ("Poeira estelar", "Explosão" e "Big Bang”). O termo "Meteoro" nos parece estar relacionado ao meteoro que atingiu a Terra há cerca de 65 milhões de anos e causou o desaparecimento dos dinossauros, evento muito posterior à origem das primeiras formas vida em nosso planeta (cerca de 3,5 bilhões de anos atrás). Uma explicação alternativa seria uma referência à teoria da Panspermia, segundo a qual micro-organismos teriam surgido em outro ponto do universo e trazidos para o nosso planeta através de meteoros que aqui teriam caído. Tendo em vista que a extinção dos dinossauros é um assunto mais popular e frequente na mídia, nos parece mais plausível que o estudante estivesse se referindo a ela e não à Panspermia. Apenas as expressões "Quatro gases da atmosfera" e "Terra primitiva" parecem se aproximar mais das teorias científicas sobre a origem da vida na Terra.

Durante esse momento, P2 ouviu as falas dos estudantes, mas não fez nenhum comentário a partir delas. Após uma estudante ter dito "Para mim foi Deus", a professora mordeu os lábios, abriu os olhos e levantou as sobrancelhas, em uma expressão que parecia indicar dúvida e certa discordância. Ainda que a aluna também parecesse notar essa possível intenção de P2, nem ela, nem a docente fizeram qualquer tipo de comentário. Próximo ao fim da aula, outra educanda perguntou à professora se "a nossa matéria não surgiu do pó?”. A docente reagiu franzindo a testa, fazendo beiço e dando de ombros, sem, novamente, comentar a fala da estudante.

Nas situações acima observadas, percebe-se que P2, em certa medida, expressa estranhamento ante as falas das alunas. Entretanto, ao não comentá-las, 
torna-se difícil compreender o porquê de tal sentimento. Uma razão possível, como vimos anteriormente no capítulo 4, é que a própria professora possui incertezas sobre suas ideias acerca de origem e evolução da vida. Nesse sentido, ao não se sentir segura de um posicionamento próprio, possivelmente não se sente plenamente confiante de desenvolver uma discussão mais a fundo em sala de aula sobre esses tópicos.

Outro fator que pode ter contribuído para tais atitudes da professora seria o possível receio de entrar em choque com a crença dos(as) estudantes. Durante sua entrevista, P2 nos contou que já havia vivenciado conflitos em sala de aula e que procurava argumentar com os alunos que o seu objetivo era que eles soubessem que a teoria da evolução existe, mas não mudar suas crenças. Ela ressaltou que antigamente os conflitos eram mais frequentes e, em geral, relacionados a alunos/as evangélicos/as:

\begin{abstract}
Há muitos anos que eu não tenho um embate. E quando tem, um aluno ou outro, que é mais evangélico... Quando eu entrei aqui tinha muito, há muitos anos atrás era muito mais forte. [...] A ponto de terem meninas que eram autorizadas a usar saião jeans, porque o pastor não permitia o uso de calça, e de cinco anos pra cá eu não lembro de ter aluna de saia aqui na escola, todas de calça. Então nessa época, eu me lembro que quando eu dava evolução e eles falavam da Bíblia e tal. Aí eu meio que saía a cavalheiro do tipo 'religiosamente você tem o direito de acreditar no que você quiser, não estou convertendo ninguém, você tem sua fé, eu também tenho a minha. Eu estou aqui te explicando um conceito científico, com tais provas, e você tem que estudar isso porque você vai fazer uma prova, você vai ser avaliada e acabou. Ninguém está obrigando você a acreditar nisso, você tem que saber que isso existe. Você sabe que isso existe? Você vai fazer a prova e acabou. Não estou te obrigando'. Então, a gente conseguia, sem embate, sem largar a turma, sem gritos, até porque isso não leva a lugar nenhum. 'Não tô aqui para converter ninguém'.[...]

Eu me lembro de uma[aluna] que pegou uma Bíblia na minha aula, eu falei 'sem problema, vamos ler', e ai a gente leu 'tá vendo, então o criacionismo, eu não falei aqui que existe o criacionismo que tá até hoje? E agora, nós aqui, o que falamos?'
\end{abstract}

Neste trecho, é possível perceber que a professora destaca a centralidade dos estudantes evangélicos em situações de conflito acerca da origem e evolução da vida em sala de aula. P2 diz que até alguns atrás esses episódios eram mais comuns, e, além disso, as meninas haviam tido autorização da escola para vestirem saias (que não fazem parte do uniforme escolar) porque os pastores de suas igrejas não permitiriam o uso de calça. Nessa época, alguns alunos falavam da Bíblia para se contraporem ao conteúdo de evolução, ao passo que ela buscava respondê-los usando de quatro estratégias: (i) o reconhecimento da crença do estudante ("religiosamente você tem o direito de acreditar no que você quiser, não estou convertendo ninguém, você tem sua fé, eu também tenho a minha”); (ii) 
o uso de "provas" científicas para explicar um conjunto de conceitos científicos; (iii) a necessidade de avaliação do conteúdo ensinado ("você tem que estudar isso porque você vai fazer uma prova, você vai ser avaliada e acabou") e (iv) o uso de textos religiosos ("Eu me lembro de uma [aluna] que pegou uma Bíblia na minha aula, eu falei 'sem problema, vamos ler"').

O primeiro ponto traz, em si, o reconhecimento da crença do estudante em certa medida, já que fala que o estudante tem direito de acreditar no que quiser. Chama atenção, porém, que a professora utilize a expressão "eu meio que saía a cavalheiro" imediatamente antes de fazer essa consideração. Esse trecho sugere que a estratégia da docente reflete certa intencionalidade de evitar discutir a questão mais diretamente - as diferenças entre as explicações científica e religiosa. O segundo ponto trata do seu foco, segundo a fala de P2, em explicar o conceito científico. Cabe ressaltar, porém, que a professora utiliza o termo "provas" e não "evidências" para se referir aos dados empíricos que dão suporte à teoria evolutiva. Tal diferença pode sugerir uma ideia de que esses dados e teorias científicas são certezas e não provisórias e sujeitas a modificações (BARNES; CHURCH, 2012). O terceiro aspecto nos parece o que menos aponta no sentido do ensino de evolução voltado para o seu entendimento, já que visa que o(a) estudante estude estes conceitos apenas para responder aos testes que fará. Tal estratégia nos parece reforçar o apartheid cognitivo (COBERN, 1996) estimulando que os estudantes fiquem ainda mais fechados a qualquer pensamento que se contraponha às suas crenças pessoais. Por fim, o quarto ponto toca novamente na crença dos(as) estudantes, porém vai além, trazendo para a aula de biologia um texto religioso. Tal atitude, da maneira descrita pela professora, parece colaborar para o respeito à crença dos estudantes sem descaracterizar a teoria evolutiva, uma vez que a docente utilizou a Bíblia para fazer um paralelo entre o conteúdo que estava ensinando e o conhecimento da religião da aluna e não para afirmar que a criação descrita no Gênesis é uma explicação cientificamente válida.

Perguntamos à professora, em seguida, por que ela acreditava que havia menos conflitos atualmente do que há alguns anos:

$P:$ Hoje em dia você não tem mais esses conflitos em sala?

P2: Não, graças a Deus.

P: O que você acha que mudou?

P2: Sei lá, eu acho que os alunos tão com maior abertura. Eu acho que esse fanatismo, de uma certa forma, está diminuindo. Ele pode até ter um pastor fanático, uma família, 
pai, mãe mais caloroso com a religião. Mas eu não sei se, pela questão do acesso, Facebook, rede social, acho que são tantas informações, acho que ele está conseguindo abrir a mente dele. Por mais que ele vá na igreja com o pai no domingo, eu acho que ele recebe muito bem. [...] eu até achei engraçado, que você pergunta: 'você acredita em Deus?', 'acredito' 'você acredita que os animais morreram, outros surgiram? 'Eu também acredito', eles acreditam nas duas coisas sem o menor problema, menor dor na consciência, para eles é tranquilíssimo. Não tem mais esse dilema, 'se eu acredito nisso, não posso acreditar nisso'. Eles estão levando isso de outra forma que antigamente não levavam.

Inicialmente, é possível perceber que a não ocorrência dos conflitos em sala é algo visto como positivo pela professora ("Não, graças a Deus"). Além disso, ela aponta três motivos para esta mudança em relação aos(as) estudantes: (i) estão mais abertos a outras ideias; (ii) têm mais acesso à informação e (iii) acreditam tanto na evolução quanto no criacionismo. Nossos dados não permitem fazer comparações com anos anteriores e, por isso, nossa análise da afirmação da professora é limitada. Os dados obtidos em nosso questionário e entrevistas indicam uma grande diversidade de crenças dos estudantes, havendo aqueles que rejeitam a teoria evolutiva, que aceitam-na e aqueles que buscam formas de conciliá-la com suas crenças religiosas.

Voltando a aula observada, após ouvir as ideias dos(as) alunos(as) descritas acima, P2 começou a falar sobre o criacionismo. Ela explica que este "é a teoria que usa Deus e a Bíblia para explicar a origem da vida". Tal uso do conceito teoria traz problemas, como discutimos no capítulo 4. Embora não tenha dito que o criacionismo é uma teoria científica, usar a expressão teoria para abordar tanto elementos do conhecimento científico quanto do religioso, não estimula ao reconhecimento das diferenças entre ambos. Esta pode ser uma estratégia para não entrar em conflito com as crenças religiosas dos estudantes, mas perde-se uma oportunidade para estudar a natureza da ciência.

Em seguida, ela perguntou à turma, se, já que no criacionismo Deus foi quem criou a vida, se os humanos e os demais seres vivos mudaram ou não. Essa pergunta provocou discordância entre os alunos com alguns dizendo que havia ocorrido mudanças e outros que não. Um dos estudantes disse que sim, porque o ser humano vinha evoluindo, enquanto outro respondeu que a evolução não tinha lógica, porque diz que "o homem veio do macaco". P2, que até então não havia feito nenhum comentário sobre a fala dos alunos, disse "eu não vim do macaco, não!". Outra educanda, então, disse em voz alta: "Em evolução eu não acredito. Se homem veio do macaco, por que o macaco não mudou?". A professora não 
desenvolveu sua própria afirmação, nem fez qualquer comentário acerca da fala da última aluna.

A situação descrita no parágrafo anterior chama atenção pelas diferentes concepções expressas pelos estudantes. Embora alguns acreditassem que as espécies não haviam se modificado, muitos também aceitavam essas mudanças, em outras palavras, a evolução dos seres vivos. É importante notar que o argumento utilizado pelos estudantes que estavam abertamente rejeitando a evolução era de que esta não fazia sentido porque o homem não veio do macaco e nem o macaco teria mudado. A ideia de que "o homem veio do macaco" é bastante difundida na sociedade, ainda que esteja cientificamente incorreta. De acordo com a teoria evolutiva neodarwinista e as evidências empíricas mais atuais, seres humanos e os primatas atuais possuem um ancestral comum extinto há milhões de anos (LESTINGE; SORRENTINO, 2008). Além disso, seres e humanos e primatas estão em constante mudança ao longo do tempo. A docente, ao não explicitar esses pontos aos estudantes, não deixa claro porque disse que não tinha vindo do macaco e não usufrui da oportunidade de explicar a ancestralidade comum, conceito de grande importância para a teoria evolutiva de Darwin (MAYR, 1982).

Ela continua a explicar sobre o criacionismo, afirmando que este está associado ao fixismo, isto é, a crença de que as espécies de seres vivos são fixas, não se modificando ao longo do tempo. Assim, os organismos existentes hoje na Terra seriam idênticos àqueles criados por Deus como narrado no relato bíblico. Além disso, ela diz que o criacionismo "É uma teoria que surgiu e que continua até hoje. Não há como refutar. Você acredita ou não". Tal consideração pode ser problemática, tendo em vista que, ainda que a crença em Deus ou em força(s) transcendental(is) responsável(is) pela criação do universo e da vida possa ter elementos sobre os quais a ciência dificilmente poderia fazer afirmações robustas, o fixismo é um postulado amplamente criticado pela teoria evolutiva neodarwinista, gozando de larga evidência empírica para tal. O registro fóssil indica que muitos seres vivos já se extinguiram e que as espécies atuais não existem desde o surgimento da vida na Terra. Em suma, ainda que o estudante acredite no criacionismo fixista, isso não impede que o fixismo seja passível de críticas do ponto de vista científico. 
Em uma aula sobre origem da vida na turma 1017, P2 seguiu a mesma dinâmica das outras duas turmas, perguntando aos alunos como achavam que a vida tinha surgido, ouvindo suas opiniões, mas sem discuti-las. As visões expressas pelos alunos ditas em voz alta foram: "Deus", "Adão e Eva", "Muitas histórias", "Big Bang”, "Macaco". Tal qual na turma anterior, é possível identificar expressões mais próximas do conhecimento religioso ("Deus" e "Adão e Eva") e do conhecimento científico ("Big Bang", "Macaco"). A menção a "Muitas histórias" chama atenção para o fato de, pelo menos um dos estudantes, ter conhecimento de que existem diversas explicações para a origem da vida além das teorias científicas e do relato bíblico apontado pelos colegas.

Em seguida, P2 pergunta à turma se já haviam ouvido falar no criacionismo e o que acham que é. Um estudante diz que Deus colocou os seres vivos na Terra, mas que continuam evoluindo. Já outro afirma que os dias da criação na Bíblia não são intervalos de 24 horas e, por isso, aceitava a ciência. A professora demonstrou grande entusiasmo com esta afirmação, pois, nunca tinha ouvido falar nessa possibilidade. Um terceiro estudante acrescentou que tinha uma visão diferente e que poderiam achar que era "maluquice". Ele disse que "o ser humano foi introduzido por seres superiores de outros planetas". A docente respondeu dizendo que não era maluquice e explicou sobre a teoria da Panspermia. Ela complementou comentando sobre o programa de TV "Alienígenas do Passado", o qual considerava "bem legal" e que abordava temas como esse. Por fim, outro educando afirmou que "a ciência procura vestígios de como Deus criou o mundo".

Analisando as falas expressas pelos estudantes acima descritas, podemos notar que vão ao sentido de conciliar o conhecimento religioso e o científico, além de uma que se remete a possíveis formas de vida em outros lugares do universo. Esses dois conjuntos de formas de se pensar a origem da vida chamam a atenção de P2. Retomando as concepções da professora discutidas no capítulo 4 e sintetizadas no mapa conceitual da figura 4.3, podemos perceber que sua visão pessoal da origem e evolução da vida se baseia, em grande parte, na flexibilização de ideias científicas e religiosas visando sua conciliação, bem como na ideia de que "não estamos sós" no universo. Nesse sentido, é possível que a professora tenha explorado um pouco mais essas ideias de seus alunos, porque se identifica 
mais com estas do que com aquelas expressas por outros educandos que se aproximam mais do criacionismo.

Ao final do primeiro bimestre, $\mathrm{P} 2$ levou parte de seus alunos a um cinema próximo ao colégio para assistir ao filme Noé, como forma de explorar mais a fundo diferentes visões sobre a origem da vida. Após o filme, a professora aplicou uma avaliação, que contaria pontos extras, em que os estudantes deveriam avaliar o filme e relatar suas impressões pessoais. De acordo com o relato da professora, o resultado atendeu suas expectativas. Ela acrescentou que alguns educandos manifestaram visões criacionistas e de que se deveria sempre obedecer a Deus. Não houve nenhuma discussão ou exposição da opinião dos alunos ao restante da turma.

A ideia de levar os estudantes para assistir a esse filme nos causou certa estranheza, pois, embora a história de Noé esteja presente no livro do Gênesis, não trata da criação do mundo em si. No entanto, em dado momento do longametragem, Noé conta a seus filhos a história da criação. A voz do personagem narra o texto bíblico, enquanto as imagens mostram galáxias, a Terra se formando, os primeiros seres unicelulares se multiplicando em várias células, formando os primeiros invertebrados, peixes, anfíbios, répteis, mamíferos e primatas. Nesse momento, há um corte na sequência e surgem Adão e Eva, iluminados, no Éden. Comem do fruto proibido, são expulsos do Paraíso e em seguida, o filme volta a mostrar Noé e seus filhos. Nessa cena, chama atenção o fato de o texto narrado ser, a princípio, criacionista e fixista, porém as imagens denotam certo sentido evolutivo. De acordo com a professora, alguns estudantes apontaram essa mescla em seu relatório.

A figura 6.2 representa o modelo de espaço de busca para P2. Suas crenças privadas são coerentes com seu discurso em sala de aula. No entanto, ela parece insegura sobre como lidar com as crenças dos alunos. Quando sua aluna afirmou que na visão dela, a vida havia sido criada por Deus, P2 fez uma expressão de dúvida e não fez nenhum comentário. É possível que a professora perceba os temas religiosos como difíceis de serem debatidos, tendo em vista tensões pelas quais ela mesma já havia passado anteriormente. Além disso, assim como no caso de P1, é possível perceber correlações entre as concepções pessoais de P2 e suas estratégias didáticas. Sua visão pessoal articula elementos do conhecimento científico e do conhecimento religioso, mas a própria professora reconhece que 
possui incertezas. Essas limitações influenciam sua postura em sala de aula, de modo que ela não se aprofunda no debate das ideias da educanda. Um espaço de busca poderia ser construído, tendo em vista que a aluna expôs, aparentemente de boa-fé, sua crença e a professora poderia relacioná-la aos conteúdos em sala de aula. No entanto, esta construção demandaria mudanças das estratégias didáticas da professora para se relacionar com a crença dos educandos. Tal limite foi representado pelo tracejado correspondente à letra "c".

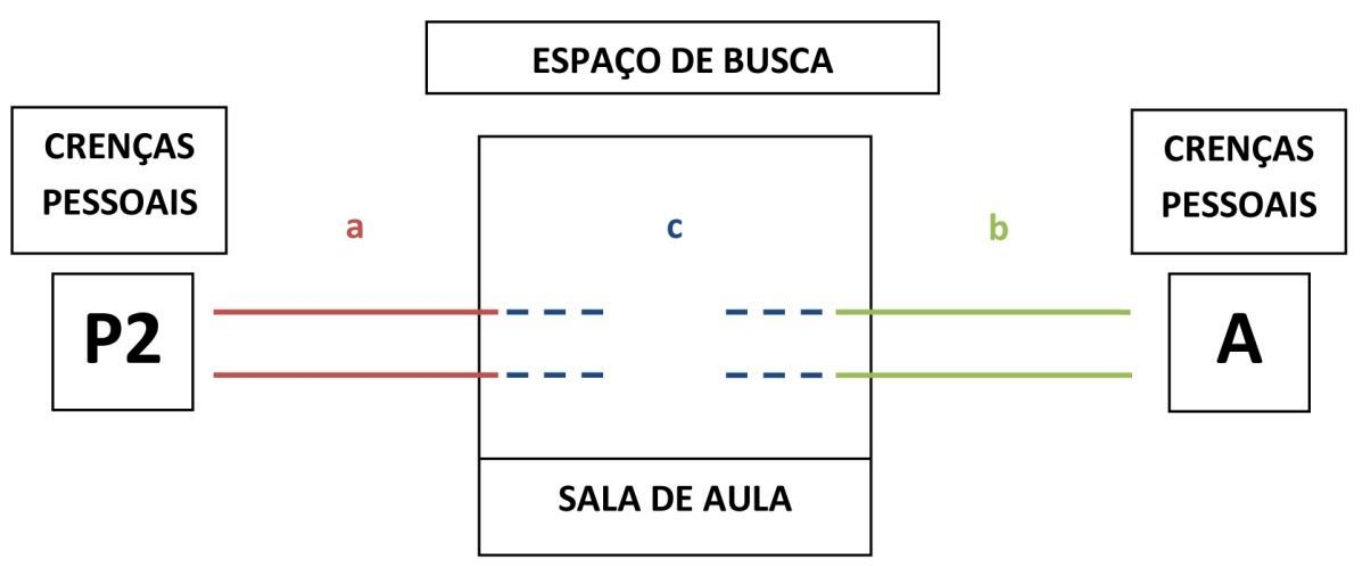

Figura 6.2: Modelo do espaço de busca para P2.

Em síntese, P2 nos parece tentar estabelecer diálogos com seus estudantes, todavia, seus aparentes receios com suas próprias concepções e com as crenças de seus estudantes, parecem erguer obstáculos. A estratégia de ouvir as visões dos educandos para a origem da vida encontra êxito em duas de suas três turmas, o que poderia ser um primeiro passo para contrastar teorias científicas e versões religiosas. No entanto, a professora não explora o pensamento que seus alunos expressam, optando por dar seguimento ao conteúdo, sem discutir o que é uma teoria científica, que tipo de perguntas a ciência pode responder e que questões a religião se ocupa de fornecer respostas. Finalmente, a exemplo de P1, cruzando-se os dados das observações e de sua entrevista, podemos perceber como as concepções pessoais se refletem sobre sua prática pedagógica, restringindo-se a comentar apenas as falas de estudantes que mais se aproximam de sua visão pessoal. 


\section{3}

\section{Aulas de P3: questionamentos e resistências}

A docente P3 trabalhava no Colégio Passaredo e estava de licença maternidade até meados do ano letivo, de modo que não deu aulas sobre origem da vida, apenas evolução, no terceiro bimestre, para as turmas 1001, 1002 e 1005. Assim, ela buscou desenvolver discussões sobre criacionismo e teoria evolutiva com seus alunos, levantando questões iniciais e posteriores de acordo com o que ia falando. Essa estratégia a permitiu ouvir diferentes opiniões dos estudantes, contudo devido ao desinteresse de alguns e a resistência de outros, foi possível perceber que alguns educandos não acolhiam argumentos favoráveis à teoria evolutiva ainda que a professora tenha procurado analisar alguns argumentos utilizados por eles e dado respostas precisas em suas intervenções. Em alguns momentos de sua aula, ela afirmou ter questionamentos sobre suas próprias ideias, o que parece ter fortalecido a rejeição das teorias científicas por parte de alguns educandos.

Em uma aula na turma 1005, vestindo uma blusa que diz "Gotta have faith" ("Tem que ter fê", em inglês), em que o " $\mathrm{T}$ ” de faith possuía o formato de uma cruz estilizada, P3 perguntou à turma o que se lembravam do primeiro bimestre. Uma aluna diz que "ia botar a carne e ia apodrecer" (em referência aos experimentos de Francesco Redi sobre o aparecimento de larvas de moscas em pedaços de carne) e "vai botar um pano e vai aparecer um rato" (referindo-se às primeiras ideias sobre o surgimento de vida a partir de objetos não-vivos, abiogênese). O estudante A8 disse logo depois "teoria da origem da vida" e P3 confirmou. A docente passou, então, a falar sobre o criacionismo e disse que "junto com a teoria do criacionismo tem a teoria do fixismo, que a vida é fixa... Que os seres vivos são os mesmos".

Ela, então, perguntou aos alunos se eles achavam que os seres vivos foram sempre da forma como são hoje. A primeira aluna voltou a se manifestar, dizendo que não, porque os seres vivos vão evoluindo. Em seguida, P3 questionou se o homem veio do macaco. Outra educanda diz que "alguns vieram", enquanto outra diz que "tem macaco branco". A docente não dá muita atenção a esses comentários e fez mais um questionamento, dessa vez se conheciam algum animal que viveu e que não vive mais. Uma aluna diz "Tem! Aquele bagulho... Dragão, 
não!’. Um colega diz em voz alta do outro lado da sala, “dinossauro!” e ela repete “dinossauro!". P3 concordou e falou que a evolução é um processo lento, que demora milhões de anos. Acrescentou, ainda, que iriam estudar o que existe para provar que os seres vivos evoluem.

No episódio descrito acima, vemos que P3 utilizava símbolos religiosos no seu dia a dia e que os estudantes conseguiam se lembrar de alguns conceitos vistos no primeiro bimestre letivo, quando tinham outro professor. É possível perceber, ainda, que, como $\mathrm{P} 2$, esta professora também associa claramente o criacionismo ao fixismo, algo que alguns alunos aparentam não aceitar. Quando pergunta se o homem veio do macaco, a resposta das alunas é em tom jocoso e sugere visão preconceituosa e racista de que determinadas pessoas se assemelhariam a macacos. É importante ressaltar que a docente vai mais além na crítica ao fixismo, utilizando-se da extinção de animais para denotar que os seres vivos se modificam ao longo do tempo. Uma aluna não consegue se lembrar do nome "dinossauros" em um primeiro momento, mas com a ajuda de um colega, logo o faz. Assim como P1 e P2, a docente P3 também faz uso da expressão "provar" o que, como discutimos anteriormente, pode sugerir que o conhecimento científico é capaz de produzir certezas absolutas.

Após essa discussão, P3 copia um trecho no quadro a partir do livro do terceiro ano do ensino médio, no qual a parte de evolução era abordada ${ }^{58}$ :

Por que os seres vivos evoluem?

Atualmente, admite-se que todos os seres vivos têm sua origem em organismos precedentes ancestrais comuns que acumularam modificações ao longo do tempo. A grande diversidade de seres vivos, quanto a tamanhos, formas, cores, comportamentos, deriva, pois, dessas alterações.

Até o século XVIII, prevaleceram entre estudiosos, as ideias criacionistas e fixistas, ou seja, a crença na criação divina e na imutabilidade das espécies.

Muitos filósofos e estudiosos rejeitavam tais ideias e admitiam a Evolução das espécies, mas não conseguiam explicá-las convenientemente.

A partir das ideias de dois cientistas naturalistas, Charles Darwin e Alfred Russell Wallace e a publicação do livro, "A Origem das Espécies", de Darwin, foi que se começou a aceitar o fato de que as espécies mudam ao longo do tempo, originando outras espécies.

Assim, podemos considerar que para entender a evolução dos seres vivos e suas relações de parentesco exige a análise de muitas evidências. Dentre elas, destacam-se os fósseis, as homologias, os órgãos vestigiais, a embriologia comparada e atualmente os dados da biologia molecular.

\footnotetext{
${ }^{58}$ Cabe lembrar que, devido a diferenças entre o currículo mínimo e a organização dos tópicos do livro didático, o conteúdo de evolução não fazia parte do livro do primeiro ano, restringindo o acesso dos alunos à informação.
} 
O trecho copiado pela professora ressalta aspectos ligados à evolução. Chama especial atenção as explicações sobre como o criacionismo era aceito não somente como uma explicação religiosa e que havia discordâncias acerca da temática, ainda que faltasse uma teoria com mais evidências para sustentá-las. Além disso, a menção ao nome de Wallace, além do de Darwin, vai no sentido de valorizar a contribuição deste estudioso para o desenvolvimento da ideia de seleção natural, algo defendido por pesquisadores da história da biologia e da história natural (DO CARMO; BIZZO; MARTINS, 2009; MAYR, 1982).

Na turma 1002, P3 seguiu a mesma estratégia da anterior, levantando questões e comentando as respostas dos estudantes. As reações dos estudantes foram bastante semelhantes, sem conflitos aparentes. No entanto, chamou-nos atenção que A10 perguntou à professora em voz alta se ela acreditava em Deus. No momento a sala estava em silêncio e dificilmente a professora não teria ouvido. P3, contudo não respondeu à pergunta do aluno. Uma possibilidade para explicar seu silêncio é uma possível fuga da controvérsia com os alunos. Outra razão pode ser a presença do pesquisador no espaço da sala de aula. É preciso reconhecer que P3 poderia ter se sentido julgada por tornar pública sua crença religiosa, o que é parcialmente verificável, tendo em vista o conteúdo expresso em sua camisa naquele dia.

Independentemente do fato de a docente ter ouvido ou não pergunta, o ato de um(a) professor(a) revelar seu posicionamento em uma controvérsia em sala de aula pode ter diferentes implicações. Hess (2009), estudando o ensino de controvérsias em escolas nos EUA, verificou que mais importante do que o(a)professor(a) mostrar sua opinião, era se os seus estudantes tinham a sensação de que ele/ela a estava impondo ou não. Os dados de sua pesquisa mostram que mesmo os alunos que tinham um posicionamento diferente do revelado por um professor acham positivo ouvir sua opinião, pois esta seria a opinião de um adulto com conhecimento sobre o tema. No entanto, Hess (2009) também destaca que em turmas em que o professor se posicionava os alunos tendiam a se manifestar menos do que naquelas de professores que não diziam sua opinião.

Em sua outra turma, 1001, P3 desenvolveu dinâmica semelhante às duas anteriores. Uma discussão com a estudante A9 abordou mais diretamente diferentes questões relacionadas ao criacionismo e evolução. A seguir, 
reproduzimos as nossas anotações do diálogo estabelecido em sala naquela ocasião:

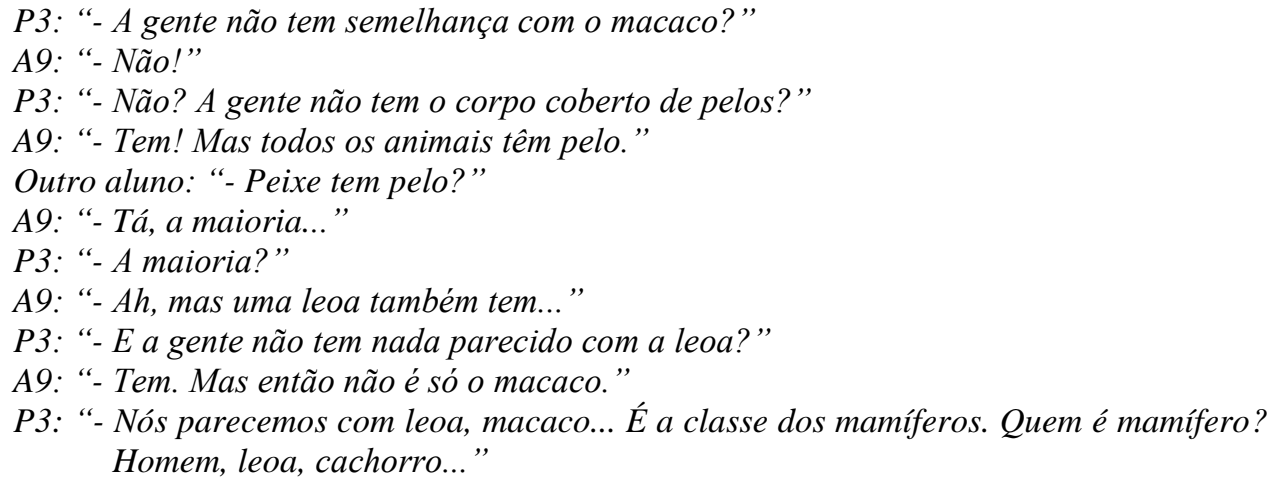

Nessa discussão, é interessante notar que P3 procura questionar as afirmações da estudante, levando-a a perceber os limites de seu posicionamento. A aluna inicia o diálogo com resistência em aceitar que os seres humanos possuem semelhanças com os macacos. Aos poucos a professora e colegas argumentam no sentido de que há similaridades e A9 concorda, ainda que pareça resistente. Em determinado ponto, ela deduz que os humanos não são semelhantes unicamente aos macacos, afirmação com a qual a professora assente.

É interessante notar que, para a estudante, considerar-se mais parecida com uma leoa é mais aceitável do que com um macaco. Nesse sentido, é possível que a resistência à teoria evolutiva neodarwinista se dê não apenas por divergir da leitura literal da Bíblia, mas também porque a ideia que A9 possui de macaco carrega valores mais negativos do que a imagem que possui de uma leoa. Enquanto no dia-a-dia a figura de macacos seja usada, com frequência, para representar algo primitivo e em expressões de racismo, leões e leoas estão mais associados à bravura e força, como "reis da selva". Quando a professora faz a conexão mais ampla com a classe dos mamíferos, atua no sentido de frisar as relações de parentesco que os seres humanos possuem com outros animais e a diversidade existente entre os seres vivos.

Se até este momento a estudante aparentava estar revendo, gradativamente, seu posicionamento, a sequência do diálogo parece indicar que isto não se confirma:

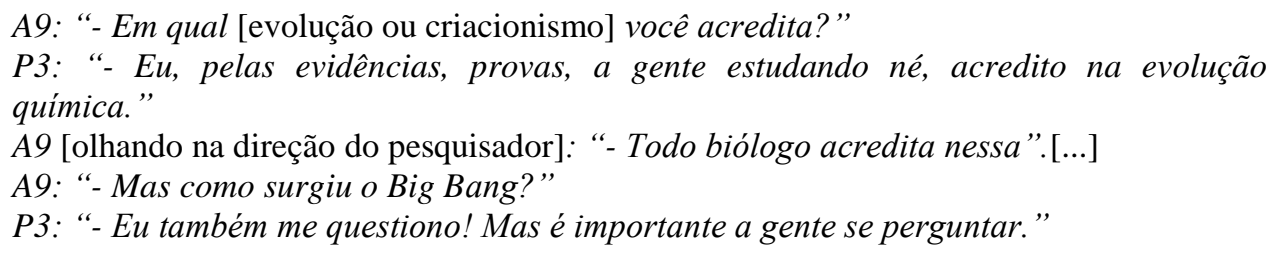


A9: “- Aí, a gente se perguntar, fica doido.” [faz um gesto rodando o indicador ao lado da cabeça].

Após a discussão apresentada anteriormente, A9 questiona diretamente a professora se ela acredita na evolução ou no criacionismo. Opostamente ao que havia ocorrido na turma 1002, ela responde, dizendo que acredita na evolução química, isto é, na teoria científica de que a vida poderia ter surgido em determinadas condições da Terra primitiva, sem a atuação de um planejador ou entidade transcendental. A adolescente, com uma expressão de que não parecia estar surpresa, olhou na direção do pesquisador e disse que todo biólogo tinha esse mesmo posicionamento ${ }^{59}$. Em seguida, A9 pergunta à professora como teria surgido o Big Bang, algo que P3 também revela se questionar. A docente acrescenta que é importante que procurem ser perguntar sobre seus posicionamentos, porém a estudante discorda, afirmando que isso atrapalharia o indivíduo ("fica doido").

Se compararmos este trecho com as declarações da entrevista de P3 sobre suas concepções pessoais, podemos perceber certo distanciamento. Enquanto em sala de aula a professora disse que acreditava na evolução, depois de certa hesitação ("Eu, pelas evidências, provas, a gente estudando né, acredito na evolução química."), quando entrevistada expressou concepções que mesclavam os conhecimentos científicos e crenças religiosas. Essa resposta parece reforçar a visão de A9 de que biólogos não acreditam no criacionismo, o que a estudante intensifica ao olhar para o pesquisador no momento em que faz essa afirmação. A tensão entre sua crença e o conteúdo que deve ensinar, parece aumentar ainda mais no momento em que a estudante pergunta como o Big Bang teria surgido. Essa é uma dúvida sobre a qual a própria docente fala em sua entrevista, como foi discutido no capítulo 4 (“'Ah, mas é a sopa orgânica, é o Big Bang, essa energia no espaço pra ter antes'. O que tinha antes disso? Só Deus pra dar esse 'start', esse início, porque o resto foi acontecendo, que permitiu isso"). Como já havíamos indicado nos parágrafos antecedentes, é possível que a presença do pesquisador na sala de aula também tenha influenciado essa hesitação na forma de P3 se posicionar diante do questionamento dos estudantes, já que poderia estar se

\footnotetext{
59 Essa fala da aluna foi anterior à sua entrevista. No entanto, ela demonstrou interesse pela pesquisa e pela presença do pesquisador em sala. Ainda assim, nunca perguntou diretamente ao pesquisador qual era sua concepção pessoal para a origem da vida e a evolução. Aparentemente, tal ideia reflete um estereótipo que a estudante possuía acerca de biólogos.
} 
sentindo avaliada e se perguntando que tipo de resposta nós "gostaríamos de ouvir".

Nesse ponto, nem A9, nem P3 parecem estar satisfeitas com a explicação científica, posto que não encontrariam resposta ao que teria dado origem ao Big Bang. Uma vez que a ciência não conseguiria explicá-lo, argumentam que apenas Deus seria capaz de realizá-lo, algo que autores chamam de "Deus das lacunas" ou "God-of-the-gaps"(SCOTT, 2009). Scott (2009) afirma que tanto cientistas quanto teólogos rejeitam essa visão. Os primeiros porque isto implicaria em violar o pressuposto do naturalismo metodológico, para o qual as explicações científicas são limitadas somente a causas naturais. Os últimos ressaltam que esta postura diminui a importância de Deus quando são encontradas explicações naturais para fenômenos anteriormente inexplicados.

Paralelamente, a posição da estudante revela que ela não se sente à vontade para mudar seu pensamento sobre as teorias científicas para a origem do universo e da vida. Quando P3 lhe diz que nós devemos questionar nossas ideias, ela diz que isso faz com que a pessoa fique "doida". Nesse sentido, pode-se perceber que, para a estudante, colocar em dúvida determinadas ideias é algo potencialmente danoso. Durante sua entrevista, perguntamos a A9 como ela havia se sentido nas aulas em que a professora abordou o criacionismo e as teorias evolutivas:

A9: Eu me sinto normal. Porque, graças a Deus, eu respeito muito a opinião dos outros. [...] Eu acredito no criacionismo, que envolve Deus. Tem pessoas que acreditam na evolução química. Eu respeito. Se a pessoa acredita naquilo é porque ela estudou aquilo e entrou na mente dela que foi aquilo que aconteceu. Eu não sinto vontade de... 'Ah, não é isso... É aquilo'. Eu acho que se um dia tiver que aparecer o que realmente foi, existe uma pessoa estudando pra isso... Pra descobrir o que realmente aconteceu. Eu acredito que se um dia surgir alguma verdade, algum fato que prove que foi... Aí, a gente vê, mas por enquanto não.

Neste trecho, a educanda diz que respeita quem acredita nas teorias científicas para origem e evolução da vida, porque essas pessoas teriam estudado muito para isso e que não sente vontade de discutir sobre isso ('Ah, não é isso... É aquilo"). Por fim, ela diz que se uma "verdade" ou "algum fato que prove" que as teorias científicas mostram "o que realmente aconteceu", ela, então, poderia reavaliar sua posição.

Essa fala indica que a estudante prefere evitar debates sobre posicionamentos que possam divergir do seu, o que pode ser visto como uma forma de permanecer mais ligada a uma ideia da qual se sente segura. Essa lógica 
parece ser reforçada quando a estudante diz que mesmo diante de provas do que realmente aconteceu, ainda iria refletir sobre sua posição. Essa mesma declaração mostra, também, que A9 considera que a ciência pode produzir certezas sobre a realidade. Nesse sentido, a compreensão das teorias científicas por parte da estudante é dificultada pela sua não-abertura a essas explicações e pela sua visão da natureza da ciência, o que também já foi relatado em pesquisas anteriores (DAGHER; BOUJAOUDE, 2005).

No episódio descrito acima, nossas observações e entrevistas parecem indicar que P3 procurou estabelecer diálogo com os estudantes em sala de aula, explorando suas concepções e discutindo evidências científicas que dão suporte à teoria evolutiva neodarwinista. No entanto, suas próprias dúvidas com relação a sua crença pessoal e seus conhecimentos em biologia e, principalmente, a resistência da estudante em se abrir para outras explicações bem como sua concepção de ciência baseada na produção de certezas e verdades, apresentam-se como obstáculos para o entendimento.

Em sua entrevista, P3 disse que teve poucos episódios de conflito em sala de aula por conta dos conteúdos de origem da vida e evolução. Quando questionada por que ela acreditava que isso ocorria, a docente declarou que fatores como o desinteresse, a falta de conhecimento da própria religião e até dificuldades de leitura fariam com que os estudantes não demonstrassem conflitos:

Às vezes, a gente até instiga pra acontecer. Nunca tive nada assim, não. [...] Porque, às vezes, eu acho que é desinteresse mesmo, entendeu? Eu acho que os alunos hoje em dia estão num período que... Foi o que eu falei, a dificuldade da leitura...Até da religião. Eles não entendem a religião deles. Não sabe ao certo, as coisas que pode e o que não pode.

Nas entrevistas com os estudantes desta professora, todavia, encontramos visões distintas. A8 dizia que achava graça pensar que "o homem veio do macaco", A10 acreditava que a professora tinha "medo" de discutir sobre religião e A7 e A19 demonstraram rejeitar a teoria evolutiva com bastante veemência:

A7: Eu [hesita] acho que tudo isso é uma mentira. Porque dizem que o mundo surgiu de uma explosão. Como uma explosão pode fazer nascer alguma coisa, se explosão destrói? Eu acho isso tudo errado, mas cada um escolhe a sua direção. Eu acho que foi uma força divina, como Deus, que criou o mundo, porque tá bem claro. Como uma coisa assim pode formar... Uma explosão? Uma pessoa vem do macaco... Como? Se viesse do macaco, o macaco estaria procriando pessoas. Ainda estariam evoluindo, mas não está. Como seria isso? Pra mim nada disso é verdade, é tudo mentira. E eu me sinto assim... Como se ela estivesse enganando as pessoas que ainda estão aprendendo, mas fazer o que? Isso é obrigatório.

P: Na sua opinião, como surgiu a vida aqui na Terra?

A7: Eu acho que foi uma força divina que criou... Porque está bem claro... Não sei por quê... Eu fui criada dessa forma, meu pai me ensinou assim, mas eu acho que foi isso. Eu 
sinto a presença de Deus na minha vida, eu sei que Ele existe, então eu acho que... Eu tenho certeza, que ele criou o mundo, entendeu?

Na visão de A7, a teoria da evolução e o Big Bang são mentiras. Ela argumenta que o Big Bang, por ela considerado como uma explosão, não poderia ter dado origem ao universo, uma vez que só teria capacidade destrutiva e não formativa. Já a evolução não faria sentido por afirmar que os seres humanos vieram dos macacos e, no entanto, estes não estão se transformando naqueles. Esta concepção da estudante, como discutimos em caso semelhante envolvendo P2, não se aproxima da concepção científica de evolução, para a qual seres humanos e outros primatas compartilham um ancestral comum. $\mathrm{O}$ mesmo vale para a visão da estudante de que o Big Bang seria uma explosão, quando, de acordo com a visão científica, marcaria o início da expansão do universo (NASA, 2014). É interessante notar que a estudante diz que se sente como se a professora estivesse tentando enganar os alunos, mas que nada poderia ser feito, porque é um conteúdo obrigatório na escola. Em sua opinião, está claro que o nosso universo e a vida foram criados por Deus, embora ela só se refira fatores ligados à sua família, formação religiosa e sua relação com Deus para sustentar essa ideia.

Assim, suas concepções de evolução e do Big Bang a levam a crer que essas teorias científicas não fazem sentido o que reforça sua crença religiosa, ainda que ela mesma não consiga construir a fundo argumentos para sustentá-la. A forma que essa resistência às teorias científicas assume indica que mesmo que o(a) professor(a) insista em esclarecer os conteúdos relacionados a elas, isso não garante que a estudante venha a compreendê-los ou minimamente aceitá-los como válidos, tendo em vista que ela os assume como mentira e como menos válidos do que aquilo que sua família lhe ensina e da sua fé, que parecem ser, segundo a entrevista, a verdade sobre o tema. É importante notar que quando a aluna diz que sente como se a professora estivesse "tentando enganar" outras pessoas, está pressuposta a ideia não só de que o conteúdo da fala da professora seria incorreto, mas também, de que esta estaria agindo de má-fé. Nesse sentido, há não só um questionamento epistemológico do conhecimento científico envolvido nessas teorias - isto é, dos argumentos para sustentá-las - porém, principalmente, moral, pois se critica a motivação do(a) docente para tal. Como Evans (2011) defende, não é uma crítica à ciência como um todo, e sim aos pontos em que esta colide com as crenças religiosas do fiel. 
Dada a discordância de A7, perguntamos-lhe por que ela não se manifestava em voz alta durante a aula e o que ela achava que era a opinião pessoal da professora:

P: Você disse assim: eu sinto como se ela estivesse enganando quem está aprendendo. Mas você nunca pensou em falar isso para a professora?

A7: Não porque aí faria um conflito... Porque ela falaria assim... 'Ah, mas é sua religião, mas tem pessoas que acreditam'. Então eu prefiro ficar quieta. E acreditar no que eu acho. Daí tem pessoas que acreditam em outras. Cada um tem a sua opinião, então é melhor cada um ficar [com] sua opinião e as outras com eles. É a função dela ensinar. Então, eu prefiro ficar quieta.

P: Qual você acha que é a opinião pessoal da professora?

A7: Eu não sei. Eu nunca perguntei, porque ela é bem focada no trabalho dela e não dá pra ver se ela tá em alguma coisa assim ou não. Ela é bem focada na aula. Ensinar a aula. Que foi 'assim e assim'. Eu não sei.

A estudante alega que prefere permanecer em silêncio a fim de evitar o conflito com a professora, já que a função dela é ensinar. Ela acrescenta que, pelo fato de existirem pensamentos e crenças diferentes, é melhor que cada um permaneça com sua. Tal consideração vai ao encontro da argumentação de Hess (2009) de que nas sociedades atuais, cada vez mais as discussões e interações com pessoas que pensam de forma diferente são evitadas. Parece-nos que tal atitude da estudante não contribui para o entendimento da teoria evolutiva e, menos ainda, para a construção da tolerância no ambiente escolar. Como aponta Andrade (2009), tolerar posições divergentes não é pouco para o desenvolvimento de uma proposta educativa que respeite as diferenças.

Posteriormente, A7 argumenta que não sabe dizer a opinião de P3 sobre a origem e evolução da vida, pois ela é muito "focada" em ensinar o conteúdo. Dessa maneira, a sua ideia de que o(a) professor(a) estaria enganando os alunos ao ensinar evolução, parece ser independente da concepção do docente. Assim, mais do que uma crítica pessoal à professora, a fala da estudante parece se opor ao ensino de evolução em si.

A Figura 6.3 mostra a representação do modelo do espaço de busca para P3. Em sua entrevista ela afirmou que acreditava que a evolução ocorria, mas que era Deus quem a conduzia e, em sua aula, por outro lado, afirmou que acreditava na teoria evolutiva - sem fazer nenhuma menção à possível atuação de Deus. Embora P3 tenha tentado estabelecer uma discussão com os alunos, sua argumentação parece encontrar limites nas dúvidas que ela própria possui sobre a origem do universo. Tal qual P1 e P2, é possível perceber que as concepções pessoais de P3 também se relacionam com sua prática pedagógica. Além disso, as 
estudantesA7 e A9 demonstram resistência em abrir-se para outras formas de pensar o relacionamento do ser humano com outros seres vivos. Assim, as linhas referentes à letra "c" são contínuas pelo lado da professora, indicando sua inclinação à discussão do ponto de vista da aluna, porém é limitada pelas próprias dúvidas da professora. Pelo lado das estudantes, as linhas são pontilhadas e também limitadas, representando suas resistências.

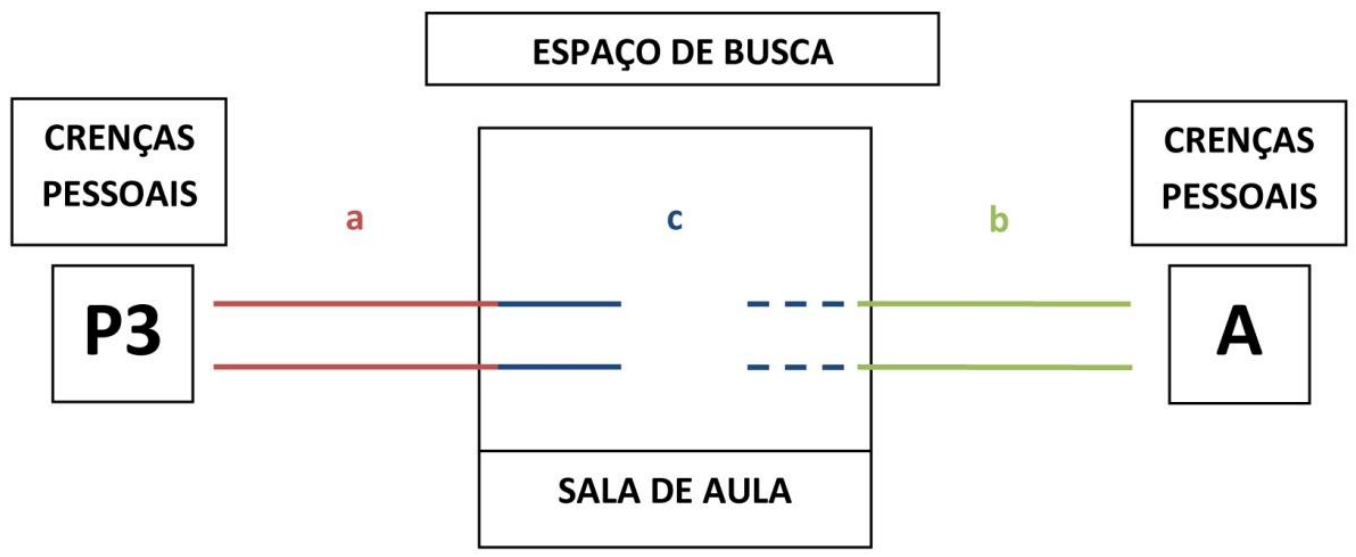

Figura 6.3: Modelo do espaço de busca para P3.

Em conclusão, P3 procura desenvolver aulas dialogadas com seus estudantes e demonstra respeitar suas crenças religiosas, focando na discussão de evidências científicas. Essa estratégia parece não estimular o surgimento de conflitos como o descrito para P1 e produz uma discussão com A9 mais profunda do que as tentadas por P2. No entanto, ainda assim, percebemos nas entrevistas que os estudantes são pouco abertos a pontos de vista diferentes dos seus e demonstram forte resistência à evolução. P3 afirma que tem poucos conflitos com os estudantes, porém, isto pode ser devido ao fato de os educandos não manifestarem suas visões abertamente. 


\section{4}

\section{Aulas de P4: religião e ciência se encontram}

A professora P4 trabalhava no Colégio Guarani e dava aula para seis turmas, das quais observamos três com mais frequência $\left(1011,1012\right.$ e 1014) ${ }^{60}$. Ao longo de todo o período da pesquisa, P4 declarou várias vezes que os casos de conflitos com alunos eram muito raros e que a rivalidade entre ciência e religião está mais para quem está fora da escola do que dentro. Ela referiu-se a apenas a um caso de uma estudante evangélica, que usava roupas longas para ir à escola, e que afirmava que Deus estava acima da ciência. P4 afirmou que, em sua visão, os alunos pensam que Deus criou tudo e que a ciência tenta explicar e, assim, não veem oposição.

Diferentemente de todos os outros docentes pesquisados, P4 não seguiu o currículo mínimo no primeiro bimestre. Ao invés de abordar o tema de origem da vida, a professora deu aulas de evolução. A razão por tomar esta atitude nunca ficou clara para nós, nem houve, até onde tomamos conhecimento, nenhum tipo de consequência para a professora.

Em uma das aulas de evolução no primeiro bimestre, na turma 1011, a docente iniciou fazendo comentários sobre o conteúdo, explicando, por exemplo, que "o homem não veio do macaco". Ela afirma que ambos vieram do mesmo tronco de símios e que não nascemos da barriga de um macaco. Em seguida, ela diz que "uma coisa é uma lei" que é uma coisa que já foi provada, que não tem como mudar no planeta Terra. Dá como exemplo a gravidade, dizendo que se um indivíduo se jogar de um prédio, vai cair. Diz que "teoria é outra coisa". Diz que teoria é uma explicação possível para fatos e que a evolução é uma teoria. O uso do termo teoria por P4 se aproxima daquele feito por P2 e P5 e que discutimos no capítulo 4. Ao sugerir uma diferença hierárquica de validade entre leis e teorias, a professora, por um lado, induz os estudantes a pensarem que a teoria evolutiva neodarwinista é uma explicação frágil e com poucas evidências. Além disso, segundo nossa avaliação, a professora também dá a entender que a ciência pode gerar conhecimentos irrefutáveis, na forma de leis.

\footnotetext{
${ }^{60}$ Observamos as aulas das outras turmas em momentos pontuais ao longo do ano, em geral quando havia ausência ou modificação no horário de outro professor participante da pesquisa.
} 
Na sequência, a professora pergunta aos alunos como eles acham que a vida surgiu. Um deles prontamente responde: "Adão e Eva". P4 diz que pode até ser, mas que como bióloga, diria que o mais aceito é que a Terra era um planeta muito quente e sem seres vivos. Ela, então, começa a comparar a visão científica e a visão religiosa. Afirma que, para a ciência, a Terra era um planeta quente e sem seres vivos. Para a Bíblia, a Terra era sem forma e vazia. P4 fala à turma: "Olha como batem!'. Continuando, afirma que a ciência fala que os primeiros seres vivos vieram da água e que a Bíblia diz que Deus criou tudo e o homem por último. Para a ciência, os sauros vieram antes do homem e, na Bíblia, as bestas feras vieram antes do homem. Segundo a explicação da professora, muitas coisas que a ciência defende batem com o que está na Bíblia. "A diferença é o autor, a diferença é no antes. A ciência não diz quem fez".

Ainda que as considerações feitas pela professora mostrem certa semelhança entre as teorias científicas e a narrativa bíblica, como Scott (2009) argumenta, essa postura implica em uma interpretação flexível demais da Bíblia, já que, se analisada mais detidamente, incoerências surgirão. Além disso, ao afirmar que a ciência "não diz quem fez", sugere que há um autor do universo, mas que a ciência não consegue determiná-lo. Entretanto, as teorias científicas partem do pressuposto de que todos os fenômenos naturais possuem causas naturais (SCOTT, 2009).

Alguns estudantes demonstraram concordar com o que a professora estava dizendo, dizendo que também pensavam assim. Esse acordo poderia ser visto como um resultado positivo de um diálogo na turma, contudo, nos parece que é uma situação problemática. Primeiramente, porque pode ser visto pelos estudantes como uma forma de doutrinação, já que P4 apresentou uma concepção pronta e baseada em suas próprias crenças aos estudantes, sem lhes oferecer oportunidades de exporem suas opiniões propriamente. Por ocupar uma posição de autoridade em sala de aula, dificilmente os alunos se sentiriam autorizados e à vontade para questionar essa visão, analisando os argumentos que a sustentam, violando os mínimos éticos esperados para um professor (CORTINA, 1996, 2008). Em segundo lugar, a fala da professora deixa de lado as diferenças entre a forma como religião e ciência constroem seus conhecimentos. O pensamento científico, baseado no estudo de evidências e análise de hipóteses, não visa se acomodar ao que uma determinada religião prega e, assim, poderá vir a produzir conhecimento 
que diverge ou não de visões religiosas. Em terceiro lugar, P4 deixa de considerar que a Bíblia pode ser interpretada de diferentes maneiras por variadas denominações. Assim como a igreja católica tende a aceitar as teorias científicas de origem e evolução da vida (PAPA JOÃO PAULO II, 1996), evangélicos pentecostais (MALAFAIA, 2009) tendem a fazer leitura mais literal do Gênesis e adventistas do sétimo dia se aproximam do design inteligente (LEMOS; BORGES, [s.d.]).

$\mathrm{Na}$ perspectiva de $\mathrm{P} 4$, porém, ela não teria "colocado" - no sentido de impor - sua crença aos alunos e que acha isso importante. Quando perguntamos qual a importância disso, ela não vai muito a fundo, dizendo apenas que em uma função como a de professor deve se ter muito cuidado:

\section{$P$ : E porque você acha importante fazer isso, de não colocar?}

P4: Porque eu creio... Aí já é lado religioso de novo, no livre arbítrio humano. Quando você está numa posição que você pode influenciar muito... Você está numa chefia, você está num comando, você é um psicólogo, você é um professor, você é um médico... Quando você está numa situação qualquer na sua vida, mesmo não profissional, mas que a sua influência é muito importante para uma pessoa... Às vezes, um amigo, está muito mal e está te pedindo um conselho, naquele momento você fica meio Deus para ele... Eu acho que quando você está nessa situação na vida, você tem que ter muito cuidado porque aquela vida não pertence a você, pertence a ela mesma. E, às vezes, quando você coloca muito as suas ideias, você vai colocar aquele ser tomando um caminho muito seu e de repente nem é o dele.

A própria professora reconhece que, enquanto docente, pode vir a influenciar muito outras pessoas - no caso, os alunos. Ela enfatiza tal ponto ao afirmar que "naquele momento você fica meio Deus para ele". O fato de P4 não avaliar sua própria postura em sala de aula como questionável, indica-nos que ela acredita que seja legítima. Ao ensinar à turma que ciência e religião, em geral, se encontram, a professora faz com que sua visão pessoal soe como a "oficial" ainda que, como vimos acima, seja problemática.

O mesmo aluno que havia falado de Adão e Eva para explicar a origem da vida disse que tinha dificuldade de entender certos elementos da Bíblia, como a mulher ter surgido a partir da costela do homem. P4 respondeu-lhe que não se sabe se foi mesmo da costela ou se essa era uma maneira de dizer que ambos são da mesma espécie. Ela aproveitou o tema e pediu à turma que procurasse para a próxima aula o número de costelas do homem e o da mulher. Ela deu a entender que o primeiro teria mais do que a última, em uma evidência da criação divina.

O sinal do recreio tocou e os alunos, agitados pela tarefa e pela afirmação da professora, rapidamente usaram seus celulares para fazer a pesquisa. Na volta 
do intervalo, P4 voltou para o seu segundo tempo naquela classe e os educandos lhe disseram que não havia diferença na quantidade de costelas entre homens e mulheres. Ela mesma leu o site que um dos estudantes havia encontrado e demonstrou certa surpresa. Ela concluiu o assunto dizendo que a costela é lateral, o que coloca homem e mulher em pé de igualdade.

Ainda na mesma aula, P4 reforçou que ciência e religião normalmente coincidem e perguntou se havia algum ateu na turma. Nenhum aluno se manifestou. Em seguida, ela diz que "até cientista acredita em Deus. Publiquei muito e sempre acreditei em Deus". Ela critica quem se diz ateu, falando em tom jocoso "Deus não existe". Um estudante não compreendeu o tom irônico que ela utilizava e, rapidamente, disse, com bastante ênfase: “Qual é, professora?! Ca $\hat{o}^{61}$ ! Para com isso!". A docente ficou confusa, mas os colegas logo explicaram o que ela estava falando, fazendo com que o aluno ficasse mais calmo.

No momento acima descrito, a professora age de forma eticamente questionável ao pedir que os estudantes ateus se manifestem abertamente para a turma e ao criticar aqueles que afirmam que Deus não existe. Mesmo que parte de sua argumentação possa ser vista no sentido de quebrar o estereótipo de que cientistas são todos ateus, ela desrespeita a liberdade de pensamento e de nãocrença de outrem. $\mathrm{O}$ fato de nenhum estudante ter se declarado ateu, não diminui a gravidade da fala da professora, tendo em vista que pode gerar impactos nas concepções dos estudantes com relação a quem não acredita em Deus e é possível que algum aluno tenha se sentido constrangido a declarar-se ateu em frente a toda a turma.

Além da atitude da docente, chama atenção a reação do aluno. Ao pensar que P4 estaria expressando sua própria crença de que Deus não existe, o estudante reagiu de forma intensa, indicando que discordava fortemente de tal afirmação. Esse fato, ainda que baseado em um equívoco do aluno, parece denotar que a tensão entre diferentes crenças e pensamentos pode estar presente e forte, mesmo que nem sempre seja manifestada pelos discentes.

A entrevista de A14, aluna de P4, parece ir ao mesmo sentido. A estudante fala que a evolução foi inventada pelos cientistas, os quais são diabólicos, para prejudicar a igreja católica:

\footnotetext{
${ }^{61}$ Gíria para mentira.
} 
P: Pensando mais nas partes que tem a ver com biologia, a professora falou algumas coisas sobre a origem da vida, evolução nas aulas... Como você explicaria que a vida surgiu no nosso planeta, na Terra?

A14: Eu acredito na Bíblia. Biologia eu só estudo porque tem que estudar. Eu não acredito muito em biologia não.

P: Como é isso, quando a professora fala uma coisa que difere da Bíblia. Como você se sente?

A14: Eu acredito que o homem criou essa história toda pra prejudicar a igreja católica.

P: Quem criou essa historia pra prejudicar a igreja católica?

A14: Eu acho que os cientistas, assim, são meio diabólicos.

P: Diabólicos? Como assim? Me explica melhor isso...

A14: Advogado do demônio. Na igreja evangélica eu aprendi que tudo que discorda da Bíblia são diabólicos.

$P$ : E você concorda com isso?

A14: Concordo.

P: Como você se sente, quando um professor está falando de uma coisa que você considera diabólica e você não acredita... Como é isso?

A14: Eu estudo porque tenho que estudar, né... Mas assim, acreditar, eu não acredito não.

Assim como A7 e A12, ela afirma que acredita na Bíblia e que só estuda biologia por obrigação. Quando questionada como se sentia quando a professora falava de algo diferente do relato bíblico, A14 declara que o homem, mais especificamente os cientistas, criaram as teorias científicas de origem e evolução da vida a fim de prejudicar a igreja católica. Ela acrescenta que os cientistas são diabólicos, pois, como ela aprendeu na igreja evangélica, tudo que não está de acordo com a Bíblia está ligado ao diabo, o que se aproxima da postura de Malafaia (2009), para quem há um plano satânico em ensinar evolução nas escolas. Ela finaliza retomando a declaração de que só estuda biologia por que isto lhe é imposto, mas não acredita.

É importante notar que, em momento anterior da entrevista, A14 disse que já havia frequentado tanto a igreja católica, quanto a evangélica, mas havia se afastado de ambas. Da primeira, porque discordava da adoração aos santos, enquanto que, da segunda, por não gostar das críticas que o pastor fazia ao catolicismo e aos estilos musicais dos quais ela gosta. Apesar de seu afastamento, não abandonou determinadas crenças - como explicita nos trechos citados acima e abaixo:

A14: O pastor falava muita coisa que eu nem ligava. [...] Ele até citava o nome da Beyoncé... Que ela era satânica. Que ela era famosa porque o demônio usava ela.

P: Você concorda com isso?

A14: Não. [...] Porque a mulher está cantando... Famosa, não quer dizer que ela está usada pelo demônio. Eu não concordo não.

P: Por que quando o pastor fala que a Beyoncé era do demônio você discordava, mas quando ele falava do cientista era do demônio você concordava?

A14: [risos] Porque a Beyoncé não está falando nada relacionado de origem da vida... Não está discordando da Bíblia. A Beyoncé está cantando música de amor, mas não envolve Deus. 
Em sua declaração é possível perceber que somente os pontos em que seus gostos pessoais se confrontavam com o pastor de sua antiga igreja foram abandonados por ela. Quando a ciência se confronta com elementos de sua crença religiosa - mantidos, apesar de ter se afastado da instituição religiosa - ela opta por permanecer com a última e ver a primeira como diabólica. Como Evans (2011) destaca, a rejeição do pensamento científico ocorre nos pontos em que este se choca com as crenças pessoais do indivíduo, em um conflito moral. Cobern (1996) se refere ao "apartheid cognitivo" como a atitude de criar muros ao redor de suas crenças para protegê-las de pensamentos que as ameacem. Nossos dados parecem indicar que tais muros podem ter diferentes "tamanhos" e "espessuras" que interferem na compreensão da teoria evolutiva.

Outros alunos de P4 tinham postura distinta. A11, católico, e A13, sem religião, declararam aceitar as teorias científicas de origem e evolução da vida. Já A1 e A3 - evangélicas - disseram aceitar tanto elementos do Gênesis quanto da teoria evolutiva.

P: Nas aulas de biologia quando o professor vai falar de origem da vida, evolução, às vezes o professor fala de umas teorias que não tem uma relação com Deus, é diferente da Bíblia. O que você acha disso?

A1: Eu já tive uma professora que ela era professora de biologia, mas ela acreditava em Deus. Então, eu acho que na biologia, os cientistas acham que não existiu Deus, né? Mas eu acho que Deus que inventou tudo, mas ao mesmo tempo, ele não chegou e... 'Ah, vou criar o humano, vou botar Adão na Terra e não sei o quê'... Ele inventou a ciência também, entendeu? Porque... Calma aí que eu tô pensando aqui... Eu acho que... Eu não sei, ao mesmo tempo que eu gosto de biologia, eu gosto de aprender ciências e tudo, mas eu ainda acredito em Deus. Eu acho também que ele inventou a ciência, apesar de cada ciência dizer que não existe Deus. Que tudo aconteceu porque tudo aconteceu por causa de um Big Bang... Não! Eu acho que existe Deus de verdade e que Deus inventou a ciência.

A fala da estudante mistura elementos do cristianismo e de teorias científicas de forma confusa. Ela vê ciência e religião como estando em polos opostos e potencialmente rivais. No entanto, paralelamente, tenta argumentar que sua opinião bebe de ambas as fontes, mencionando que já teve uma professora de biologia que acreditava em Deus, e que resiste em acreditar no surgimento de Adão, nem no Big Bang. Por fim, a afirmação de que "Deus inventou a ciência" reforça a ideia de mescla entre conceitos científicos e sua crença religiosa.

A figura 6.4 representa o modelo do espaço de busca paraP4. Suas crenças privadas correspondem ao que ela diz em sala de aula. No entanto, ela não promove um debate com os alunos, apenas expõe sua visão. Por conseguinte, 
houve um potencial para o espaço de busca, entretanto não foi desenvolvido, mesmo que parte dos alunos tenha concordado com ela. Seria necessário que suas opiniões fossem abertas o suficiente para que os alunos se envolvessem em uma discussão construtiva, ainda que pudessem vir a discordar dela. Além disso, ao expor sua crença pessoal, a professora, pela posição de poder que ocupa dentro da sala de aula, corre o risco de que ela seja vista como a melhor ou a única opção possível pelos alunos. Nesse sentido, procuramos representar tal limitação na construção do espaço de busca através de segmentos de reta tracejados e pontilhados que possuem um tom mais claro do que o do modelo "ideal". Havia a possibilidade de promover o diálogo em sala de aula, todavia esta não se concretizou.

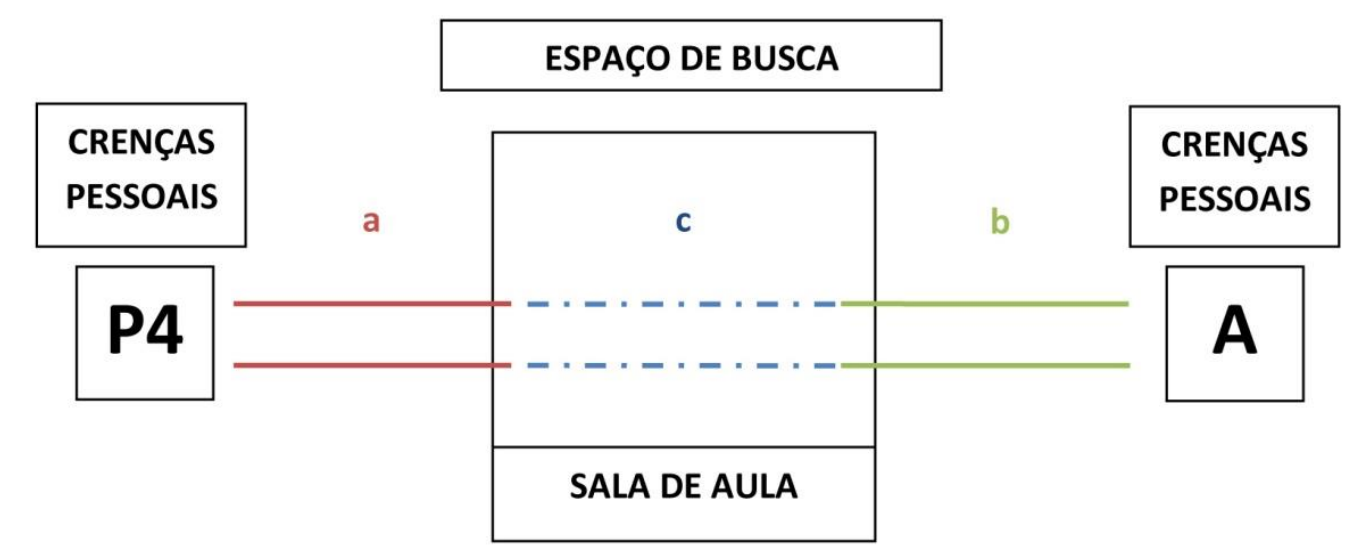

Figura 6.4: Modelo do espaço de busca para P4.

Em suma, embora P4 diga que apenas tenha passado por uma única situação de conflito ao longo de toda sua carreira - para o qual não dá muita importância - e que esses conflitos seriam muito mais comuns para quem está fora da escola do que para quem está dentro, nossos dados indicam que este pode ser um limite de percepção da professora. As falas de estudantes durante as aulas e entrevistas mostram que alguns deles estão em profundo desacordo com o que está sendo ensinado. Além disso, ao dizer à turma que religião e ciência coincidem, coloca sua visão pessoal como sendo a legítima, o que é questionável de um ponto de vista ético. É possível, ainda, que a ausência de conflitos mais explícitos em suas aulas se deva, justamente pelo fato de colocar ciência e religião como compatíveis. Uma vez que a própria docente já estabelece essas conexões, os alunos podem vir a considerar a aula como menos ameaçadora às suas crenças pessoais. 


\section{5}

\section{Aulas de P5: fronteiras entre saber e acreditar}

O professor P5, como descrevemos no capítulo 4, é católico e tem uma história de participação ativa em sua comunidade religiosa. Sua concepção pessoal sobre a origem e evolução da vida mesclava elementos de conceitos científicos e religiosos, em uma versão própria e complexa. Em suas aulas não foram observados conflitos explícitos, tais como estudantes demonstrando irritação com algo que o docente falou ou com algum conteúdo ensinado. Uma estratégia pedagógica utilizada pelo professor parece contribuir para isto: P5 anunciava aos alunos que podiam acreditar no que quisessem, mas que deveriam saber tanto as teorias científicas sobre origem da vida quanto o criacionismo. Embora esta abordagem aparentemente vá ao encontro de uma proposta de ensino da teoria evolutiva neodarwinista voltada para o seu entendimento, a postura dos estudantes em sala, suas entrevistas e a não diferenciação explícita entre ciência e religião parecem indicar que isto não ocorre. Pelo contrário, essa proposta expõe criacionismo e teoria evolutiva como duas alternativas equivalentes e que tanto faz qual delas será a escolhida do aluno, desde que responda corretamente à prova. Assim, ignora-se que ciência e religião são formas de conhecimento autônomas, distintas e, por vezes, divergentes e concorrenciais.

No início do ano letivo de 2014, P5 começou a trabalhar no Colégio Passaredo, nas turmas 1001, 1002 e 1005, nelas atuando até junho, quando P3 retornou de licença-maternidade. Dessa maneira, ele abordou apenas os conteúdos de origem da vida, no primeiro bimestre. O criacionismo e suas características foram o primeiro tópico do ano a ser abordado, para, em seguida, serem introduzidas algumas teorias científicas de origem da vida. Contudo, antes de tocar no assunto, P5 disse em todas as suas turmas que determinados conteúdos que vão ver em biologia podem ter conflito com a religião deles. Acrescenta que "cada um acredita no que quiser, mas saber, tem que saber tudo". Durante sua entrevista, ele apontou essa estratégia como uma das razões possíveis para não ter experiências de conflitos com alunos em sala de aula:

P: Você dando aula já teve algum episódio de conflito com aluno sobre esse tema? J: Não... Acho que é porque eu coloco logo no início da aula, cada um tem o direito a ter a sua opinião, o seu direito de... Cada um tem a sua opinião e tem que saber dessas duas... Eu nunca cheguei ainda... Pode ser que venha a ter, até porque eu normalmente falo isso no primeiro dia de aula. Primeiro dia de aula muita gente falta. Mas acho que 
justamente por essa minha maneira de abordar, deixando eles livres pra acreditar no que eles quiserem, saber o que tem que saber, acreditar no que quiser, então eu acho que nunca tive problema em relação a isso não.

Neste trecho, P5 argumenta que por frisar que os alunos podem ter as crenças que desejarem, mas que terão que saber tanto o criacionismo como a teoria evolutiva, nunca teve conflitos em sala, ao que se refere como um problema. É interessante notar, ainda, que ele não descarta a possibilidade de vir até conflitos, principalmente porque faz essa introdução na primeira aula do ano, quando muitos alunos estão ausentes ${ }^{62}$.

Os alunos de P5 que entrevistamos, também foram estudantes de P3 e discutimos suas concepções sobre as aulas de biologia anteriormente. Como vimos, A7, A9, A10, A18 e A19 percebem diferenças claras entre suas crenças religiosas e os conteúdos estudados nas aulas e expressam forte rejeição deste. No entanto, com frequência, se baseiam em concepções alternativas de conceitos científicos para recusá-los, como dizer que a teoria evolutiva neodarwinista não faz sentido porque afirma que os humanos vieram dos macacos. Assim, a estratégia do professor, ainda que vise o respeito à crença dos estudantes - algo fundamental em sociedades plurais e democráticas - permite aos estudantes que percebam suas crenças e concepções como válidas, inclusive aquelas que se tornam obstáculos para o entendimento das teorias científicas.

Em uma aula na turma 1005, P5 perguntou à turma quem "veio" primeiro, o ovo ou a galinha. Após alguns instantes de discussão entre os estudantes, o docente disse que havia duas respostas possíveis: uma seria a teoria evolutiva "que vai estar na prova e nos concursos", que diz que é o ovo, pois os répteis já botavam ovos. A outra é a teoria criacionista - "é a Bíblica" - que diz que foi a galinha, pois foi criada por Deus. Em seguida, diz que uma teoria é diferente de uma lei. Enquanto a lei já foi testada, comprovada e não pode mudar, a teoria seria um conjunto de "indícios que levam àquilo ali". Ele cita, como exemplo, a teoria da origem da vida, da qual não podemos ter certeza, "porque ninguém estava lá para ver".

\footnotetext{
${ }^{62}$ Embora o número de estudantes nas duas escolas pesquisadas tenha diminuído ao longo do ano letivo, as primeiras semanas tinham frequência mais baixa que as imediatamente posteriores. De acordo com os professores e direção, isso se dava, principalmente, porque muitos alunos decidiam só ir para as aulas após o carnaval, isto é, mais de um mês depois do início do período letivo.
} 
É importante destacar que o uso do conceito teoria em suas aulas é dúbio: ora como uma forma de valorizar o criacionismo - referindo-se à teoria criacionista -, ora para questionar a teoria evolutiva neodarwinista e, possivelmente, o cientificismo - "é uma teoria e não uma lei”. Tal concepção já havia sido expressa tanto por P5, quanto por P3 em suas entrevistas. Se, por um lado, sugere que criacionismo e teoria evolutiva são igualmente válidos de um ponto de vista epistemológico, por outro, cria uma suposta hierarquia entre leis e teorias, tratando a ciência como uma atividade capaz de produzir conhecimentos inquestionáveis e reduz teorias a meras hipóteses. Além disso, o professor referese à observação direta como o único critério possível para avaliar a validade de uma teoria, algo que também apontamos para P1 e P2 e que é problemático, tendo em vista que esta não é um método infalível e que a ciência utiliza de muitos outros métodos para a produção de seu conhecimento. Por fim, é possível perceber o uso de certa coerção para que os alunos estudem a teoria evolutiva, quando o professor diz que essa é que vai estar nas provas e concursos. Logo, se quiserem ter um bom desempenho nesses exames, devem estudá-la.

Outro momento em uma aula na turma 1001 também chama a atenção. Quando P5 falava sobre a origem e evolução da vida, um aluno disse "Meu pai não é macaco!". O docente respondeu dizendo que não iria dizer qual a teoria era certa e qual era a errada. Nesse ponto, nos parece, novamente, uma tentativa de mostrar respeito à crença do estudante e não impor a visão científica. Entretanto, além do uso dúbio do conceito de teoria mais uma vez, o professor dá a entender que teoria evolutiva neodarwinista e criacionismo se equivalem. Não apenas isto: deixa de explicar que humanos e macacos compartilham um ancestral comum e, portanto, a teoria evolutiva não diz nem que viemos de macacos, nem que o pai do estudante era um destes.

A Figura 6.5 representa o modelo do espaço de busca para P5. O segmento de reta "c" pelo lado dos alunos é inexistente, já que os estudantes pouco manifestaram suas visões, oferecendo poucas oportunidades para a discussão. Quanto ao lado do docente, este se encontra tracejado e curto indicando a pouca profundidade e limites na exploração do tema. 


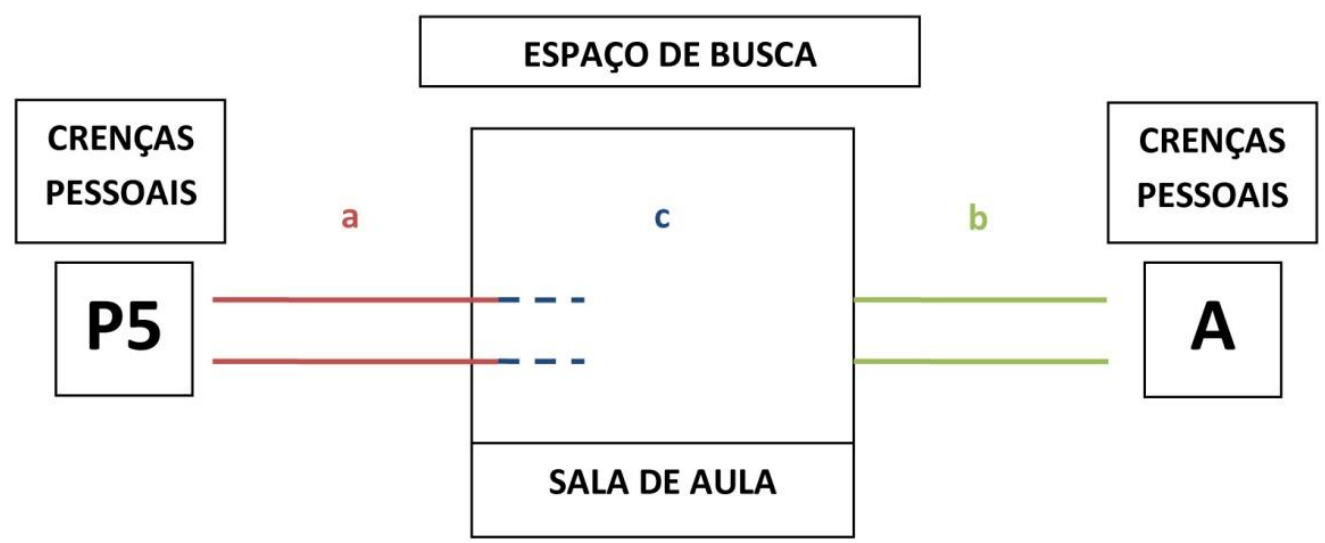

Figura 6.5: Modelo do espaço de busca para P5.

Baseando-se no argumento de diferentes autores de que o ensino de evolução deve estar baseado no seu entendimento e não na mudança de crença do estudante (COBERN, 2000; REISS, 2009; SMITH; SIEGEL, 2004; SMITH, 2010a), a abordagem do professor parece bastante promissora. Afinal, ele estaria explicitando sua intencionalidade de que os estudantes entendam os conteúdos ensinados, mas que são livres para crerem no que quiserem. No entanto, esta estratégia, descolada de uma abordagem mais clara da natureza da ciência e da forma de produção do conhecimento religioso, bem como da desconstrução de determinadas concepções dos estudantes com relação à teoria neodarwinista da evolução, encontra limites. Assim, não bastaria apenas reconhecer que os estudantes têm direito de professarem sua fé e ter as crenças que desejarem. Seria necessário enfatizar as diferenças entre ciência e religião e a autonomia entre ambas.

\section{6}

\section{Aulas de P6: tensões expostas e veladas}

O professor batista P6 trabalhava no Colégio Passaredo e dava aula para apenas uma turma de primeiro ano, 1004. Devido ao processo de diálogo e negociação com a escola para que a pesquisa fosse ali conduzida, deixamos de assistir à sua primeira aula no ano, quando abordou mais diretamente o criacionismo. O tema não foi abordado pelo professor no terceiro bimestre, quando o conteúdo de evolução foi ensinado. No entanto, pudemos observar alguns momentos de suas aulas em que tratou pontualmente do pensamento 
criacionista e o docente também nos forneceu o material didático em que se baseou para fazer anotações no quadro. Assim como ocorreu com outros professores, embora não tenhamos presenciado conflitos em sala, alguns de seus estudantes entrevistados demonstraram forte resistência à teoria evolutiva neodarwinista.

O material didático que o professor declarou ter usado e copiado, em parte, no quadro, tratava-se do "Caderno de Atividades Pedagógicas de Aprendizagem Autorregulada" (SEEDUC, [s.d.]). Este material foi elaborado para a modalidade de ensino à distância oferecido pela Secretaria de Educação, porém também é ofertado aos professores de ensino presencial, na plataforma online Conexão Professor. Uma das seções utilizadas pelo professor comparava o "método científico" e o "método criacionista":

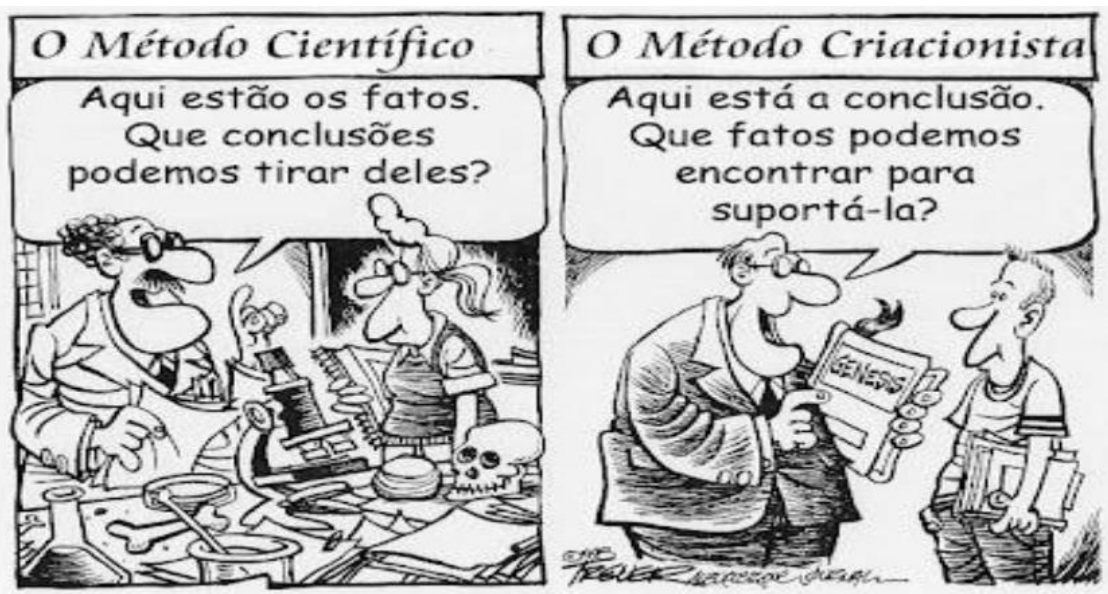

Figura 6.6: Cartum comparando o "método científico" e o "método criacionista". Fonte: "Caderno de Atividades Pedagógicas de Aprendizagem Autorregulada" (SEEDUC, [s.d.]).

O professor declarou ter copiado no quadro as frases " $O$ método científico: aqui estão os fatos. Que conclusões podemos tirar deles?" e "O método criacionista: aqui está a conclusão. Que fatos podemos encontrar para suportála?’. A imagem mostra à esquerda um homem, que veste um jaleco e está próximo de um possível estereótipo de cientista, com uma série de instrumentos e papéis em um ambiente que se assemelha a um laboratório dizendo a uma jovem que ali estão os fatos e, a partir deles, devem elaborar conclusões. Do lado oposto, um homem que veste terno e não está próximo de um possível estereótipo de cientista, carrega um livro em cuja capa se lê "Genesis" e diz a um garoto que ali está a conclusão e que devem, a partir dela, encontrar dados. Há um sentido de crítica ao criacionismo nessa imagem, tendo em vista que enquanto o cientista 
estaria agindo de forma racional, recolhendo os dados para, posteriormente, chegar a conclusões, o criacionista ignoraria os fatos e defenderia a sua visão de qualquer forma. Esse argumento nos parece problemático, pois (i) trata a atividade do cientista como puramente racional, linear e não influenciada por teorias e pensamentos prévios ao seu estudo e (ii) representa os que creem no criacionismo como pessoas que distorcem intencionalmente a realidade para acomodá-la a suas crenças. Certamente que determinados grupos criacionistas ignoram conhecida e vasta produção científica que contradiz argumentos de que a natureza seria perfeita, inerentemente teleológica e de complexidade irredutível (ANNAS, 2006; AYALA, 2008; PADIAN; MATZKE, 2009; SCOTT, 2009). No entanto, pelo conteúdo das entrevistas dos estudantes, parece-nos que sua retórica está distante da utilizada por esses grupos pró-criacionismo, ainda que acreditem em determinadas formas de criação divina. Assim, cabe questionar se, ao utilizar o quadrinho - que faz uma crítica válida a determinados movimentos criacionistas não estaria se criticando a crença dos estudantes.

Em outra aula, P6 falava sobre o filme "A Criação", que conta a história de Darwin, principalmente, das polêmicas envolvidas quando da publicação de " $A$ Origem das Espécies". Ele o exibiu para os alunos em um sábado, como reposição de aulas por causa da copa do mundo ${ }^{63}$ e lamentou que poucos estiveram presentes. Quando perguntado por um estudante se "deu matéria", o docente disse que "não". Ao terminar de fazer comentários sobre o filme, sem que nenhum outro aluno se manifestasse, disse "vamos voltar à matéria". Essas duas falas nos indicam que nem $\mathrm{P} 6$, nem seus educandos deram tanto valor ao filme quanto dariam a uma aula como as que eram mais comuns (frontais, expositivas e centradas na figura do professor).

P6 ainda comentou que o filme era um drama sobre sua vida e mostrava Darwin como um cientista cético e sua esposa muito religiosa. Quando ele terminou de escrever seu livro, o mostrou para sua esposa que o leu e autorizou que ele o publicasse. No filme ela diz "Que Deus nos perdoe", pois, de acordo com P6, aquilo estava afrontando Deus. Ele acrescentou, ainda, que as pessoas da época distorceram suas ideias, dizendo que o homem veio do macaco. Assim como o quadrinho acima, os pontos destacados pelo professor sobre o filme

\footnotetext{
${ }^{63}$ Também não tivemos a oportunidade de assistir a essa aula, pois o professor não nos informou
} de seu planejamento. 
enfatizam o conflito entre evolução e criacionismo. No entanto, não observamos nenhuma reação dos estudantes em sala de aula contra a teoria evolutiva.

É interessante notar que embora não tenhamos presenciado conflitos entre P6 e seus alunos com relação aos temas de origem e evolução da vida, alguns de seus alunos manifestaram forte resistência às ideias científicas durante suas entrevistas. Esse foi o caso de A6 e A16. O último enfatizou que, em sua opinião, a evolução é uma mentira, já a primeira ressaltou que gosta do jeito que o professor fala desses assuntos, mas não deixa de acreditar literalmente na Bíblia:

P: E quando o professor fala disso, você tem a sua visão e ele apresenta outra, como é isso?

A6: Eu fico rindo. Eu não falo assim, não. A gente meio que estudou o Big Bang... Quando ele apresentou o Big Bang, ele falou que acreditava em Deus, só que ele achou muito poético as coisas... Sim, é um pouco poético, sim. Mas acho que foi aquela coisa que está ali na Bíblia.

P: Como assim poético?

A6: Eu acho que... A forma de linguagem... Tá na Bíblia é diferente... Como eles falam...

É uma coisa bem poética, entendeu? Mas ainda assim, eu acredito.

P: Acredita...?

A6: Em Deus, na Bíblia. Porque tem gente que acredita em Deus, mas não acredita na Bíblia. [...] Porque tem que ter algum motivo. Se não tivesse sentido, porque a Bíblia estaria aqui? Porque falaria de Deus, entendeu? Tudo tem um propósito na vida. [...]

P: Você acha que a sua religião influencia de alguma maneira como você vê as aulas aqui na escola?

A6: Não... Nosso professor, o P6, ele não fala, meio de uma maneira ateu, ou então sem religião nenhuma, é a maneira como ele fala. Depende a da maneira como a pessoa fala, entendeu? Mas até agora não.

P: Você gosta da maneira como ele fala?

A6: Sim. Gosto.

P: E por quê?

A6: Porque tem professores que são mais... Como vou dizer... Do jeito que eles falam, sei lá, são meio estranhos, entendeu?

P: Estranho por quê? O que tem de estranho?

A6: É... Do jeito que ele fala é uma coisa mais leve, entendeu? Não é aquela coisa... 'Ai não é isso. Não, é isso. É o Big Bang. É isso que foi a teoria'. Ele fala meio que no geral. Ele fala... 'Mas a Bíblia é muito poética'. Aí dá pra acreditar numa boa. Dá pra fazer isso. Se ele "ofendesse”, entre aspas, o evangélico, a Bíblia, aí sim.

Neste trecho, a estudante inicia sinalizando certa concordância com uma visão "poética" da Bíblia, que seria a forma como o professor falaria em sala. Logo em seguida, todavia, ela diz que acredita no texto bíblico como este está escrito, já que, do contrário, não faria sentido acreditar na Bíblia. Na sequência, ela diz que gosta da maneira como P6 apresenta os conteúdos, pois ele não imporia suas ideias, nem ofenderia os evangélicos.

Chama a atenção que, ainda que o professor enfatizasse a oposição entre evolução e criacionismo, a aluna não se sentiu incomodada por isso. Pelo contrário, ela revela ter gosto pela abordagem do docente, posto que esta não 
ameaça sua fé. De fato, P6 mostrou evolução e criacionismo como opostos, mas não afirmou que uma seria correta e a outra errada. Ao fazer isso demonstra respeito à crença dos estudantes e não contradiz suas próprias concepções, de que Deus estaria atuando no processo evolutivo - como discutimos no capítulo 4. O professor, em sua entrevista, revela, porém, que já teve um caso de conflito em sala de aula com estudantes evangélicos:

\begin{abstract}
P: Você já teve alguma dificuldade em sala de aula quando foi ensinar esses temas de evolução?

P6: Acontece muito com os alunos evangélicos... Alguns têm a cabeça muito fechada e sempre quando eu começo a falar eu digo: 'vamos deixar um pouco a religião de lado, vamos focar na aula. Depois se vocês quiserem questionar, quiserem falar sobre alguma coisa, a gente abre pra gente debater'. A aula prossegue, mas sempre tem algum que dá aquela travada e... 'Professor, o que o senhor está falando é'... 'Não! Eu estou explicando a matéria, é teoria, você tem que ouvir. Eu não estou falando que o que você acredita é errado, estou falando que você precisa aprender. Se você for fazer um vestibular, você for fazer alguma coisa, isso vai cair e você precisa saber. Mesmo que pra você, não seja certo'.

P: Tem algum caso mais específico que tenha tido algum conflito?

P6: Não porque os conflitos nunca foram tão... Assim, tão... Ferrenhos. Teve um que foi um pouco mais. [...] Mas eu consegui contornar a situação. Até mesmo, acabei expondo o meu ponto de vista pra eles. Eu falei: 'Eu sempre explico, mas eu tenho o meu ponto de vista'. Mas eles sempre querem saber o meu ponto de vista. Então eu passo o meu ponto de vista pra eles também. E através do meu ponto de vista... Eu falei assim: 'Ó, cada um tem o seu ponto de vista. Quer ter o seu ponto de vista? Pode ter, mas você tem que saber as outras opiniões'. E assim a situação foi resolvida.
\end{abstract}

Neste trecho, vemos que P6 ressalta que alguns alunos evangélicos são menos abertos a visões diferentes das suas, algo que ele tenta contornar quando enfrenta alguma resistência em sala. Ele diz que pede para que deixem a religião de lado e demonstra ter certa disponibilidade para debater as ideias de origem e evolução da vida. No entanto, também usa de coerção, como P3 e P5, dizendo que farão provas sobre aqueles conteúdos. Quando os professores argumentam que o estudante deve entender determinado conteúdo porque vai cair na prova, deixa implícito que, se ele não souber, vai ter um desempenho ruim na prova. Como o aluno vai querer evitar isto, ele vai acabar tentando aprender aquele conteúdo. Não há uma valorização do ato de estudar pelo que ele pode trazer de bom ou pelo interesse de aprender algo novo, apenas um reforço de algo negativo. Quando fala de um caso específico que viveu, P6 afirma que expôs suas próprias concepções aos estudantes, como forma de mostrar que mesmo ele possui crenças que não estão completamente alinhadas com a visão científica. Revelar seu posicionamento é algo que pode ser bastante problemático, como discutimos para P4. A situação descrita por P6 nos parece distinta daquela professora, pois ele teria anunciado sua perspectiva durante uma discussão com uma aluna, algo que 
não ocorreu na aula de P4. No entanto, o uso da coerção também nos faz questionar até que ponto o docente esteve, de fato, aberto a ouvir a posição da educanda. Dado que não presenciamos o episódio referido por P6, não podemos ir mais a fundo nas consequências de sua atitude sobre a turma e suas aulas.

A Figura 6.7 mostra o esquema do espaço de busca para P6. Assim como P5, seus estudantes pouco demonstraram suas visões pessoais em sala e, por isso, não há o segmento de reta "c" pelo lado dos educandos. Uma vez que o professor procurou mostrar as diferenças e tensões entre ciência e religião, em certa medida, o segmento "c" pelo seu lado é preenchido, mas de alcance restrito pela limitação imposta pelos alunos.

ESPAÇO DE BUSCA

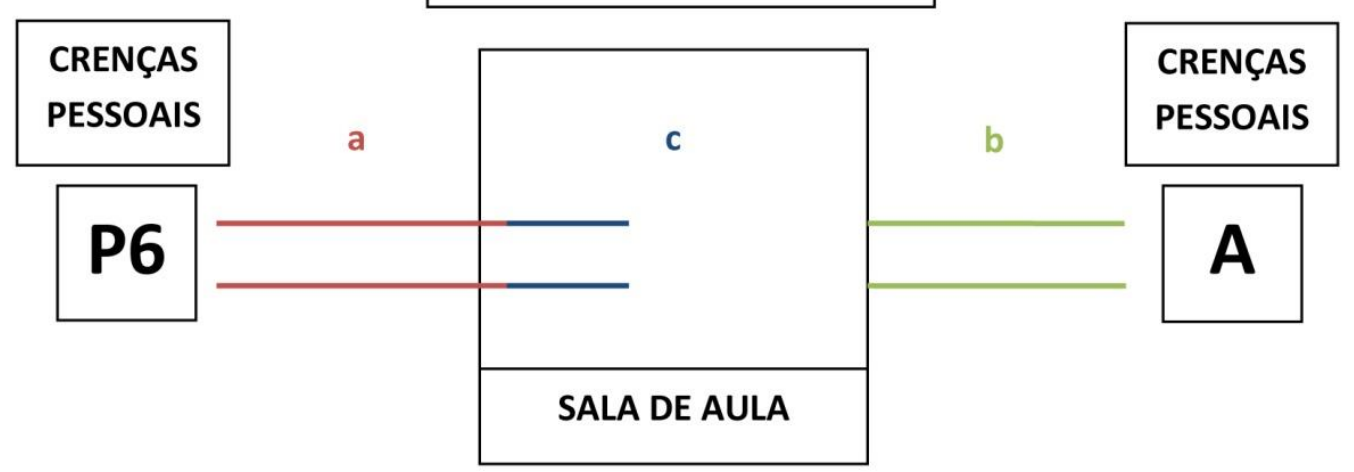

Figura 6.7: Modelo do espaço de busca para P6.

Em suma, P6 expôs tensões entre conhecimento religioso e científico em suas aulas, mas evita colocar suas próprias crenças para os alunos, fazendo-o apenas em casos de conflitos. Os estudantes de suas turmas à época da pesquisa não manifestaram conflitos abertamente em sala de aula, ainda que alguns tenham revelado forte resistência às teorias científicas durante as entrevistas. $\mathrm{O}$ fato de não fazer críticas duras ao texto bíblico foi apontado por uma de suas alunas como um fator importante para que gostasse da estratégia didática do professor para abordar esses tópicos, bem como a sua atitude de não impor seu posicionamento pessoal. 


\section{7}

\section{Aulas de P7: tensões expostas, mas poucas reações}

O professor P7 trabalhava no Colégio Guarani e dava aula nas turmas 1003, 1005, 1006 e 1007, das quais observamos as duas últimas em com maior frequência. Ele se declarou budista, porém já havia passado por diversas denominações religiosas cristãs. Em suas aulas, apresentou não só o criacionismo e a teoria da evolução química para o surgimento da vida, mas também incluiu um mito de um povo africano, como forma de ressaltar que há diferentes explicações para esse fenômeno. Quando questionado por uma aluna, revelou seu posicionamento pessoal, dizendo acreditar na ciência. Além disso, criticou a leitura literal da arca de Noé, chamando atenção para o tamanho que esta deveria ter, caso tenha realmente existido. Por fim, o docente utilizou episódios da série de documentários Cosmos, em sua versão mais recente. Nestes eram mostradas as histórias de figuras, como Giordano Bruno e Charles Darwin, que viveram controvérsias relacionadas a determinados grupos religiosos.

Em sua entrevista, P7 disse que já tinha passado por situações de conflito em sala de aula, quando trabalhava em um colégio estadual em Itaguaí, município do estado do Rio de Janeiro com grande presença de evangélicos pentecostais:

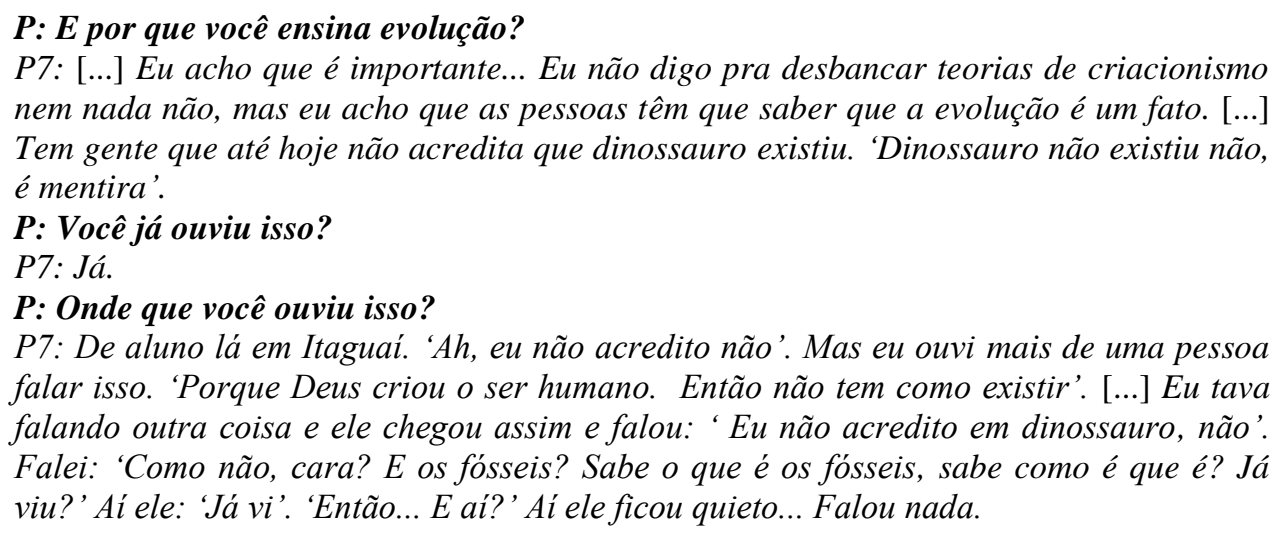
nem nada não, mas eu acho que as pessoas têm que saber que a evolução é um fato. [...] Tem gente que até hoje não acredita que dinossauro existiu. 'Dinossauro não existiu não, é mentira'.

P: Você já ouviu isso?

P7: Já.

P: Onde que você ouviu isso?

P7: De aluno lá em Itaguaí. 'Ah, eu não acredito não'. Mas eu ouvi mais de uma pessoa falar isso. 'Porque Deus criou o ser humano. Então não tem como existir'. [...] Eu tava falando outra coisa e ele chegou assim e falou: ' Eu não acredito em dinossauro, não'. Falei: 'Como não, cara? E os fósseis? Sabe o que é os fósseis, sabe como é que é? Já viu?' Ai ele: 'Já vi'. 'Então... E aí?' Ai ele ficou quieto... Falou nada.

No trecho acima, o professor destaca a importância de ensinar evolução para que os alunos entendam que a evolução é um fato. Ele usa, como exemplo, a situação de um aluno que não acreditava que dinossauros existiram. P7 perguntoulhe se conhecia os fósseis, deixando implícito que esses são uma evidência da existência daqueles animais. $\mathrm{O}$ estudante disse que sim, mas quando o docente insistiu para que explicasse seu ponto de vista, ele permaneceu calado. Nesse caso, é possível que o estudante tenha ficado em silêncio para evitar um conflito 
mais intenso com o professor, como A7 afirmava fazer, preferindo permanecer com sua concepção pessoal, ainda que esta fosse passível de crítica.

Observamos situação semelhante em uma aula de evolução na turma 1003 , na qual quatro alunas disseram não acreditar em dinossauro. P7 indagou-lhes o que achavam que eram os fósseis, ao que uma delas respondeu dizendo "Sei lá. Só acredito vendo". Nesse caso, é possível perceber mais uma vez a importância dada por diferentes sujeitos de nossa pesquisa à observação direta como forma de construir conhecimento. Como argumentamos anteriormente, esta é de grande importância, mas não é única forma, principalmente quando se trata da evolução. É importante ressaltar que houve alunos que discordaram dessas colegas e destacaram os fósseis e a existência de petróleo como evidências de organismos que se extinguiram há milhões de anos.

Mais adiante, P7 argumenta que insiste em falar sobre outras visões para a origem e evolução da vida porque os estudantes evangélicos seriam muito fechados sobre essas questões:

P7: Lá em Itaguaí, acho que 90\% da turma era evangélica. Eu acho que aqui também a grande maioria é evangélica. [...] É importante mesmo ter essa discussão na sala de aula, porque, tem que mostrar. Tem que mostrar outras visões... Porque infelizmente, principalmente lá em Itaguaí, qualquer opção de acesso até de lazer ou de qualquer outra coisa, é muito mais difícil que aqui. Desde acesso à internet, essas coisas todas. [...] Com a mente assim, sem exercício, sem ver outras coisas... Acaba, na minha opinião, o que a igreja evangélica faz muito. Deixar a pessoa com a visão muito limitada. Eu acredito que a religião evangélica... De todos que eu conheço, pode ter alguma que não. Não sei dizer tá? Mas as que eu conheço e que eu tenho experiência, que eu já vi, já ouvi e tal... Torna a pessoa muito limitada. [...]

No trecho acima, o professor ressalta que, em sua visão, a maioria de seus alunos seria evangélica. Além disso, em locais onde os estudantes têm pouco acesso à informação e opções de lazer, as igrejas evangélicas - pelos menos as que ele conhece - limitariam sua visão de mundo. A afirmação do professor, em certo sentido, aproxima-se da fala dos educandos que entrevistamos, que se mostram fechados a formas de pensamento diferentes das suas. Cabe destacar o uso de frases como "De todos que eu conheço" e "as que eu conheço e que eu tenho experiência, que eu já vi, já ouvi e tal", que indicam uma preocupação do professor quanto a generalizações sobre as ações das igrejas evangélicas.

P7 começou a trabalhar no Colégio Guarani mais de um mês depois do início do ano letivo. Ele assumiu turmas que haviam sido designadas inicialmente para P1, porém este não possuía horário compatível. Assim, suas aulas no primeiro bimestre foram em menor número que a de seus colegas. Na primeira 
delas que observamos, na turma 1007, P7 abordou diferentes ideias para origem da vida. Ele iniciou a lição perguntando aos estudantes como pensavam que a vida havia surgido. Houve poucas respostas e todas foram expressões ditas de forma solta pelos educandos: "evolução", "Big Bang", "explosão", "primeiro átomo". Chama atenção que nenhuma delas fala sobre Deus ou algum elemento religioso e três delas se referem à origem do universo e não da vida propriamente dita.

Na sequência, P7 pergunta à turma se alguém pode lhe explicar o que a teoria do criacionismo diz. Após alguns instantes de silêncio, o próprio professor diz que é a ideia de que o mundo foi criado por uma entidade, uma divindade e que, no Brasil, a versão mais comum é a do cristianismo, que está enraizada em nossa cultura. Um aluno, então, fala "é o Gênese" e uma aluna diz que "no início era céu e terra e Deus criou o mundo em sete dias", ao passo que o docente a corrige dizendo que foram seis, pois Deus teria descansado ao sétimo. É importante notar que, somente ao se referir diretamente ao criacionismo, é que alguns estudantes que até então estavam calados, se manifestaram.

Logo em seguida, uma estudante pergunta a P7 em que ele acreditava. O professor, imediatamente e sem hesitar, respondeu: “eu não acredito na Bíblia. Eu acredito na ciência, mas a ciência não sabe dizer com certeza. Outras religiões creem em outras formas de criação. Eu não conheço". A aluna não fez nenhum comentário, bem como nenhum de seus colegas.

Assim como P4, P7 também revela seu posicionamento pessoal. Diferentemente daquela professora, ele só o faz depois de ser questionado por uma aluna. Embora sua fala sugira que a crença nas teorias científicas exclua a possibilidade de se acreditar na Bíblia ${ }^{64}$, ele chama atenção para o fato de a ciência não ter certeza de como a vida surgiu. Como apontado por Lederman (2007), a constante mudança e o fato de não poder se afirmar que determinado conhecimento científico é definitivo, é um dos fatores importantes quando se ensina sobre a natureza da ciência. Além disso, P7 também frisa que outras religiões possuem explicações distintas para o surgimento da vida, ainda que desconheça exemplos.

Em aulas posteriores, ainda no primeiro bimestre, P7 exibiu em suas turmas dois episódios da série "Cosmos", lançada em 2014. O seriado, uma

64 Como discutimos no capítulo 4, P2, P3, P4, P5 e P6 buscam conciliar suas crenças, flexibilizando, porém, não descartando completamente, o que a Bíblia diz. 
atualização do homônimo da década de 1980, apresentado pelo astrônomo Carl Sagan, fala sobre características do universo e da Terra, inclusive o surgimento e evolução da vida em nosso planeta. A versão atual é apresentada pelo astrofísico Neil deGrasse Tyson que, tal qual Sagan, narra e conduz cada episódio, usando grande variedade de imagens e animações.

No primeiro episódio da série, e também o primeiro exibido pelo professor, é contada a história de Giordano Bruno, padre católico, que foi condenado à morte na fogueira pelo tribunal da Santa Inquisição no século XVI. Cosmos o representa como uma mártir, por ter sido executado por defender as ideias de Copérnico de que o Sol, e não a Terra, seria o centro do universo. A animação e a música utilizada no episódio reiteram o texto narrado e mostram Bruno como um visionário sendo preso, torturado e humilhado por membros da Igreja Católica retratados com feições agressivas e sombrias (Figuras 6.8 e 6.9). De acordo com Shackelford (2009), a visão de Bruno como um mártir do pensamento científico foi construída no final do século XIX por autores que queriam reforçar a oposição entre religião e ciência, com superioridade da última. Bruno teria sido condenado pelas implicações teológicas de suas afirmações de que existiriam outros planetas semelhantes à Terra: existiria mais de um Adão, uma Eva e pecado original, o que afetaria a crença na singularidade da redenção dos pecados por Cristo. De fato, Tyson afirma que Bruno não era cientista, não possuía evidências empíricas para suas alegações e que seu legado foi defender uma ideia que mais tarde seria explorada por Galileu e seus estudos com telescópio. Porém, tal declaração toma apenas alguns segundos e não usa nenhuma animação, o que indica que o argumento do filme não a valorizaria tanto quanto as cenas anteriores. 


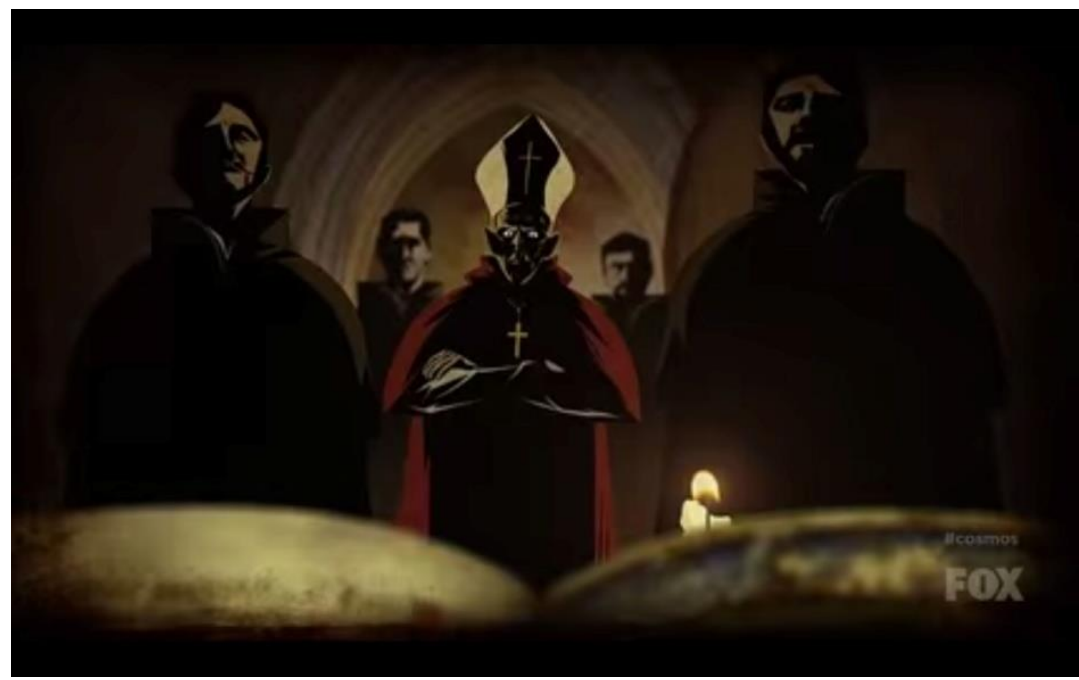

Figura 6.8: Frame do primeiro episódio de Cosmos representando membros da Igreja Católica (Copyright @ 2014 Cosmos Studios/ Fuzzy Door Productions/ National Geographic Channel/ Six Point Harnnes/ Fox).

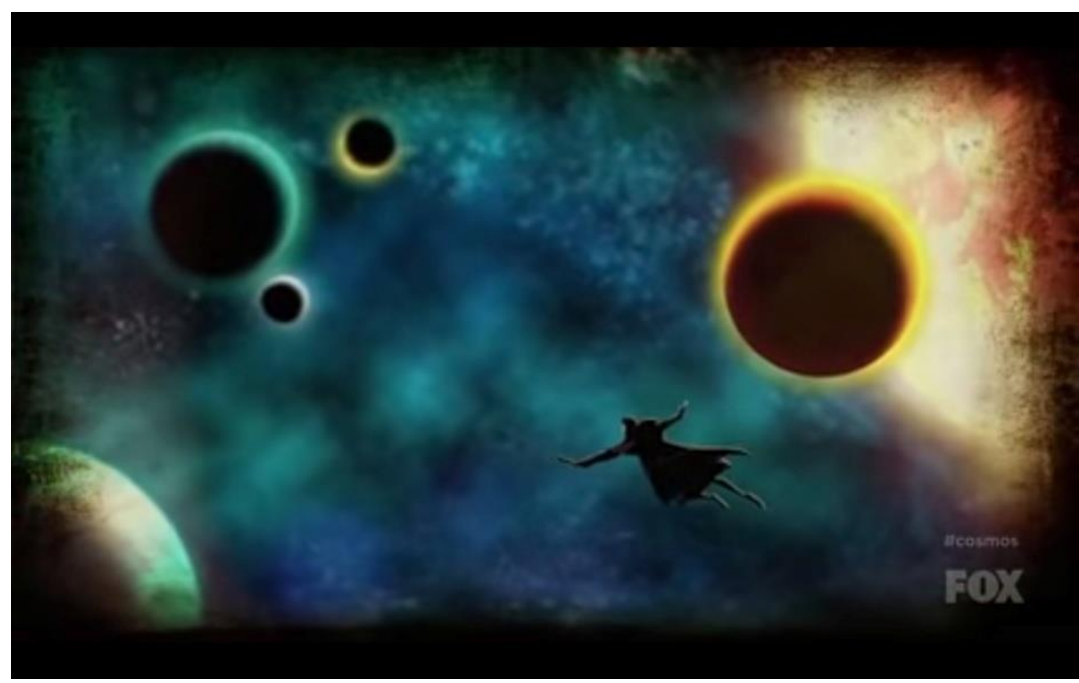

Figura 6.9: Frame do primeiro episódio de Cosmos representando Giordano Bruno em um sonho, viajando pelo universo (Copyright ( 2014 Cosmos Studios/ Fuzzy Door Productions/ National Geographic Channel/ Six Point Harnnes/ Fox).

O segundo capítulo da série também foi utilizado pelo professor. Este se dedica inteiramente à evolução, apresentando e explicando evidências de que os organismos vivos se modificam ao longo do tempo. Com animações e efeitos visuais de ótima qualidade, tópicos como seleção natural, seleção artificial e diversidade são abordados. Neste episódio, Tyson se refere genericamente a pensamentos que envolveriam a ação de um planejador inteligente ou criador para a vida na Terra, sem usar as expressões "criacionismo" e "religião". O apresentador diz que é compreensível que, à primeira vista, nos sintamos incomodados em admitir que exista um parentesco comum entre humanos e macacos, porém ressalta que temos ancestralidade comum com todas as formas de 
vida. Em uma clara crítica aos defensores do criacionismo e do design inteligente, Tyson diz que a teoria da evolução consegue explicar a complexidade dos seres vivos, usando, como exemplo o olho humano. Os olhos são usados como exemplo da ação de um criador desde o início do século XIX, na obra Natural Theology do padre anglicano Willian Paley (BROOKE, 1991) e repetidamente criticado por diversos autores (DAWKINS, 1996; SCOTT, 2009; YOUNG, 2004). São ressaltados, ainda, o caráter não-teleológico da evolução e a aleatoriedade das mutações - mas não da seleção natural em si. Tyson também afirma que a evolução, assim como a gravidade, é um fato científico e não mera opinião, como quando alguém diz que se trata "apenas" de uma teoria - usando esse conceito erroneamente. Vale destacar que, próximo ao fim, o documentário frisa que a ciência trabalha na fronteira entre a ignorância e o conhecimento e que não há vergonha nisso, ressaltando os limites do conhecimento científico.

Além das críticas cuidadosas a alegações criacionistas, há algumas menções pontuais de termos que seriam mais identificados com o conhecimento religioso do que o científico. Em um determinado trecho do episódio, Tyson analisa o interior de uma célula e diz que "se a vida tem um santuário ${ }^{65}$, é aqui no núcleo, que contém o DNA, a antiga escritura do nosso código genético e está escrito em uma língua que todas as formas de vida podem ler". Mais adiante, afirma que "aceitar nosso parentesco com toda forma de vida na Terra, não é apenas um fato científico. Na minha opinião, é também uma experiência espiritual" (Figura 6.10). Se as duas primeiras ainda podem ser vistas como metáforas, a última revela a visão pessoal do apresentador. Dado que a teoria da evolução não faz afirmações sobre a existência de espíritos ou do envolvimento metafísico de pesquisadores sobre o mundo natural, a declaração nos parece problemática. Barbour (2000) faz crítica semelhante a Carl Sagan, que na primeira versão de Cosmos, também manifestava sua visão pessoal de ilimitada confiança no método científico e críticas a visões não-científicas do mundo. Durante e após a exibição dos episódios os alunos permaneceram em silêncio, não demonstrando de forma explícita incômodo com seus conteúdos. Depois da projeção, o professor perguntou o que os estudantes tinham achado do filme, que partes eles mais haviam gostado, mas a discussão não avançou além de opiniões dispersas. Não

\footnotetext{
${ }^{65}$ Todos os grifos nestes trechos são nossos.
} 
houve um debate mais aprofundado sobre possíveis relações entre os conteúdos e as crenças dos discentes.

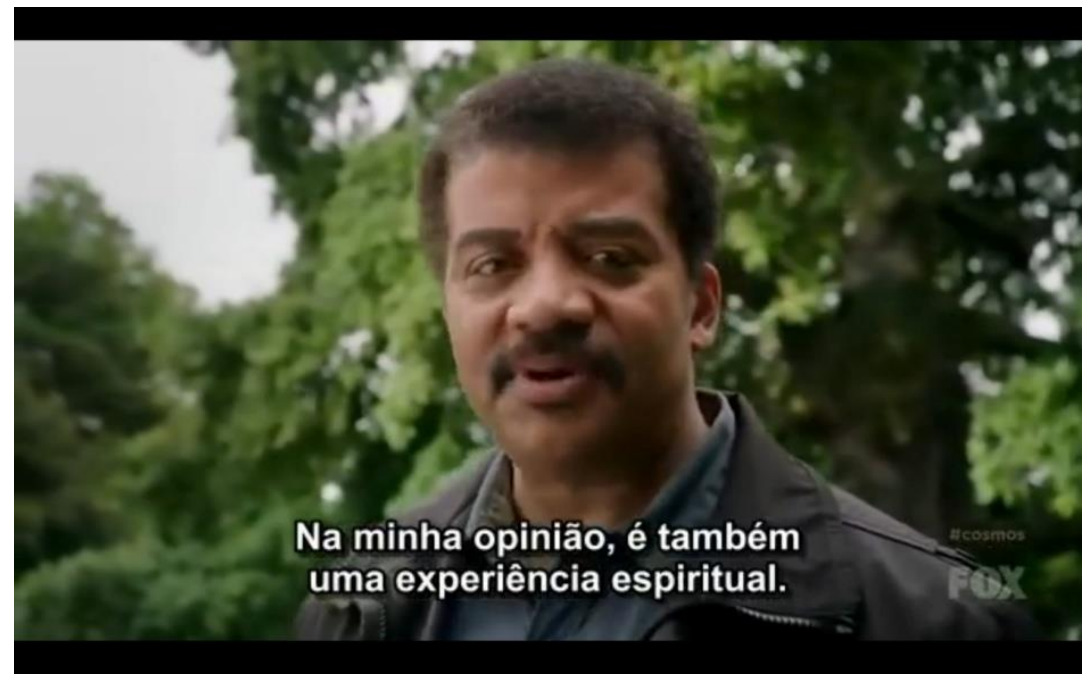

Figura 6.10: Frame do segundo episódio de Cosmos em que Neil deGrasse Tyson afirma que "aceitar nosso parentesco com toda forma de vida na Terra, não é apenas um fato científico. Na minha opinião, é também uma experiência espiritual" (Copyright (C) 2014 Cosmos Studios/ Fuzzy Door Productions/ National Geographic Channel/ Six Point Harnnes/ Fox).

Já no terceiro bimestre, P7 voltou a abordar alguns elementos da origem da vida, antes de começar a falar sobre as teorias científicas de evolução. A fim de chamar atenção dos estudantes para diferentes formas de se falar das origens, leu para suas turmas uma adaptação de um conto africano sobre a origem da vida e do ser humano (Anexo 3). A história fala de Napi, criador e guardião da vida, que molda os seres vivos a partir do barro e designa a cada um deles um local para viver. Todos reclamam de onde vivem e Napi os troca de lugar. Após esta mudança, todos, exceto o ser humano, se dão por satisfeitos. O humano não se contenta com nenhum lugar específico e Napi o permite habitar onde quiser. Por essa razão, o humano se espalhou por diferentes ambientes.

Na turma 1006, P7 disse que há várias histórias de criação e que a Bíblia é aquela que está mais próxima de nós. Ele pergunta aos alunos se alguém poderia contar a história da arca de Noé, mas ninguém se manifesta. Posteriormente, um estudante diz que há vários indícios de que os animais de antigamente não eram como os atuais e dá como exemplo o fato da arcada dentária de alguns deles ter mudado. O professor assentiu e disse que a ciência diverge de várias religiões, mas que iriam estudar a visão científica. Nenhum aluno reagiu à afirmação do professor, permanecendo todos calados. 
Na turma 1003, P7 seguiu a mesma estratégia didática, lendo o conto de Napi. Perguntou aos estudantes se conheciam alguma outra história de criação, ao que dois alunos prontamente responderam "Bíblia" e "Adão e Eva". Um terceiro ainda disse que, de acordo com a mitologia grega, haveria um ser muito forte quatro braços e quatro pernas, o qual os deuses cortaram ao meio, dando origem ao homem e a mulher. O docente, então, indagou a turma se essas histórias poderiam ser verdade e ponderou "não quero ir contra a religião de ninguém". Remetendo-se à arca de Noé, perguntou à turma se seria possível colocar um casal de cada espécie em uma arca. Um aluno responde dizendo que "em uma só, não". Outros dizem que precisaria de seis estádios de futebol e que "pensando assim, naquela época haveria animais que estão extintos. Tipo o Dodôo6". Reforçando o questionamento da viabilidade da arca, P7 complementou dizendo que se existirem dois milhões de animais, teria que por um par de cada, que daria quatro milhões.

No momento acima descrito, P7 faz uma crítica à leitura literal de determinados trechos da Bíblia e, também, de outros mitos. Mantendo a atitude de ensinar a visão científica, como havia dito na turma anterior, ele levanta questionamentos aos estudantes, induzindo-os a apontar possíveis limitações da história da arca de Noé. Ainda que o professor tenha dito que não quer ir contra a crença de ninguém, nos parece que sua postura caminha em uma linha tênue na tensão entre ciência e religião. Os estudantes gozam de liberdade de crença encarado aqui como um mínimo ético das sociedades plurais contemporâneas (CORTINA, 1996, 2008) -, inclusive no literalismo bíblico. A crítica à arca pode ser vista como uma crítica a uma determinada crença e, assim, violaria os mínimos éticos. Por outro lado, a hipótese de uma arca para abrigar todos os animais existentes na Terra não encontra respaldo em evidências empíricas, o que, de acordo com Smith e Siegel (2004) seria passível de questionamento por parte do professor. Tendo em vista que o objetivo do ensino de evolução e de biologia deve ser o entendimento e não a mudança de crença, o professor deve insistir em explicar qual é a versão científica e como ela é construída, deixando a critério do aluno escolher em que vai acreditar, por mais que haja extensa disponibilidade de dados que indicam que a evolução ocorreu de fato e de que não houve uma arca

\footnotetext{
${ }^{66}$ Ave não voadora da ilha de Madagascar e um dos mais conhecidos casos de extinção pela ação humana.
} 
de Noé. Cabe reconhecer, ainda, que muitos grupos cristãos não leem a Bíblia de forma literal e, portanto, não encontram tantas tensões entre sua fé e os conhecimentos científicos. Nos capítulos anteriores, vimos que mesmo entre estudantes evangélicos havia espaço para questionar o texto literal da Bíblia.

A Figura 6.11 mostra o modelo de espaço de busca aplicado ao caso de P7. Tal qual P6, este professor procurou mostrar tensões existentes entre o criacionismo e a teoria evolutiva neodarwinista. Seus estudantes, contudo, pouco demonstraram suas visões pessoais e, por isso, o traçado de "c" pelo seu lado é inexistente. Assim, apesar dos esforços do docente, não foi possível se estabelecer um espaço de busca propriamente dito, que buscasse o entendimento de evolução.

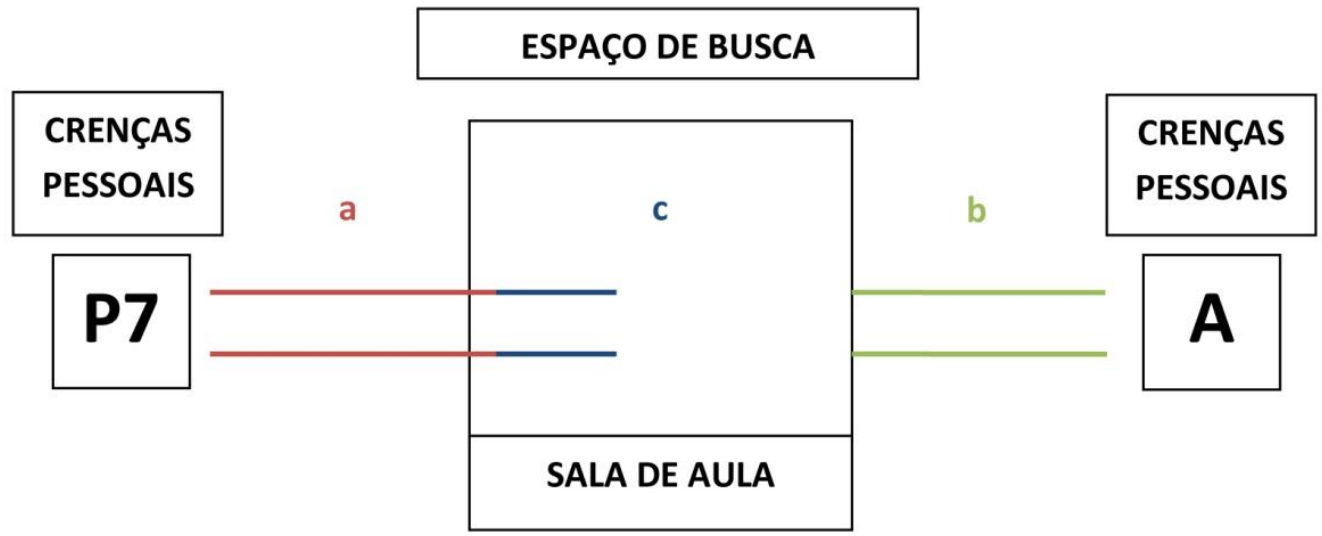

Figura 6.11: Modelo do espaço de busca para P6.

Em síntese, P7 procurou expor tensões entre os pensamentos científico e criacionista às suas turmas. Não observamos conflitos explícitos, apenas discordâncias pontuais quando se falou da existência de dinossauros. Os documentários utilizados pelo docente continham cenas que exploravam essa tensão, mas nem P7, nem seus alunos demonstraram grande interesse ou incômodo com elas. É possível que o desinteresse dos estudantes e o tom calmo do professor também tenham contribuído para que não tenhamos presenciado conflitos.

\section{8}

\section{Saerjinho}

Nenhuma avaliação bimestral feita pelos professores pesquisados trazia questões que abordassem direta ou indiretamente o criacionismo ou outras 
concepções religiosas para a origem e evolução da vida. É possível que os professores não dessem tanto valor a essas questões ou, ainda, que não quisessem abordar tal temática em provas para evitar controvérsias. Todavia, não temos dados suficientes para analisar essas hipóteses. Apenas nos exames do Saerjinho do primeiro e do terceiro bimestres é que encontramos referências a essas visões:

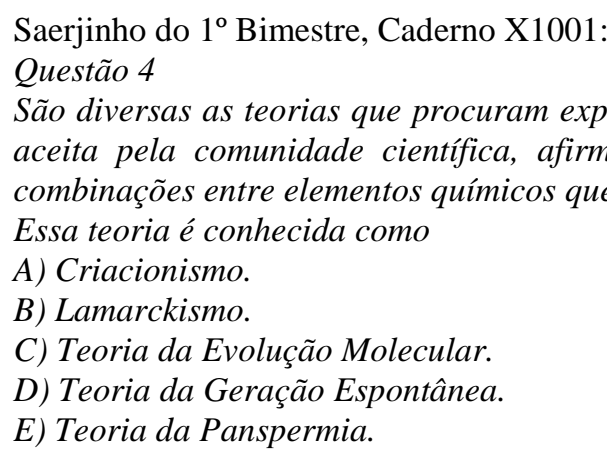

Saerjinho do $3^{\circ}$ Bimestre, Caderno X1001:

Questão 5

Os cientistas afirmam que o surgimento dos primeiros ancestrais da espécie humana se deu há aproximadamente 4 milhões de anos. De acordo com suas pesquisas científicas, o homem teve origem a partir

A) da combinação de coacervados.

B) da criação pelos poderes divinos.

C) da evolução do macaco chimpanzé.

D) de adaptações sofridas pela espécie Homo sapiens.

E) de um ancestral comum com os macacos Pongidae.

Em ambas as questões há uma referência às concepções criacionistas: na primeira a alternativa "a" cita o "criacionismo" e na segunda, a letra "b" se refere à "criação pelos poderes divinos". Além disso, ambas desejam avaliar os conhecimentos dos estudantes sobre as ideias e teorias defendidas pelos "cientistas" e pela "comunidade científica", evitando-se afirmar que haveria uma única resposta possível para toda a sociedade.

No entanto, é preciso destacar que as questões se baseiam apenas na memorização de conteúdos e não promovem uma reflexão sobre diferenças epistemológicas entre o pensamento e a atividade científicos e visões criacionistas e conhecimento religioso. Além disso, como discutimos anteriormente, o Saerjinho não gozava de reconhecimento nem dos professores, nem dos estudantes. Dessa maneira, o mais provável é que a presença dessas questões fosse irrelevante para ambos os grupos. 


\section{9 \\ Distribuição dos índices e variáveis por turmas: levantando hipóteses para a possibilidade de conflito}

Outro ponto importante a ser avaliado é se os índices e variáveis discutidas no capítulo 5 podem vir a ser usados para prever a possibilidade de haver um conflito explícito em sala de aula, isto é, quando um estudante de crenças criacionistas questiona abertamente e em voz alta os conteúdos relacionados à teoria evolutiva neodarwinista. Baseando-nos na literatura discutida no capítulo 2 e nos elementos utilizados para a construção dos índices, poderíamos levantar a hipótese de que as turmas com maiores chances de desenvolver esses conflitos seriam aquelas com menores médias de aceitação dos aspectos científicos da evolução (fator AC) e entendimento da evolução, bem como com maiores médias de aceitação da narrativa bíblica (fator NB), de religiosidade intrínseca (RI), de religiosidade organizacional (RO), religiosidade não organizacional (RNO) e maior presença de evangélicos. Estas seriam as situações em que a teoria evolutiva, em tese, seria mais rejeitada pelos estudantes da turma. As tabelas a seguir mostram as principais turmas que se encaixam em cada um desses casos.

\begin{tabular}{|c|c|c|c|c|}
\hline \multicolumn{5}{|c|}{ Fator Aceitação aspectos científicos da evolução (AC) } \\
\hline Turma & Escola & Média & $\mathbf{N}$ & Desvio Padrão \\
\hline 1006 & Passaredo & $-0,7496822$ & 11 & 1,42200341 \\
\hline 1005 & Passaredo & $-0,4577309$ & 29 & 1,12347188 \\
\hline 1001 & Passaredo & $-0,3463546$ & 16 & 0,92086598 \\
\hline 1024 & Guarani & $-0,3423716$ & 16 & 1,00115916 \\
\hline 1013 & Guarani & $-0,3110156$ & 23 & 1,43447663 \\
\hline 1003 & Guarani & $-0,2935370$ & 25 & 1,04236248 \\
\hline 1012 & Guarani & $-0,2792191$ & 25 & 0,86076138 \\
\hline 1025 & Guarani & $-0,1499803$ & 26 & 1,18571383 \\
\hline 1015 & Guarani & $-0,1319912$ & 24 & 0,79205903 \\
\hline 1010 & Guarani & $-0,0294328$ & 20 & 0,96719892 \\
\hline
\end{tabular}

Tabela 5.21: As dez turmas com menores médias do fator AC. 


\begin{tabular}{llclr}
\hline \multicolumn{5}{c}{ Fator Aceitação da narrativa bíblica (NB) } \\
\hline Turma & Escola & Média & N & Desvio padrão \\
$\mathbf{1 0 0 2}$ & Passaredo & 0,4854953 & 22 & 0,72086478 \\
$\mathbf{1 0 1 5}$ & Guarani & 0,3248255 & 24 & 0,88047986 \\
$\mathbf{1 0 0 1}$ & Passaredo & 0,3117014 & 16 & 1,01928490 \\
$\mathbf{1 0 0 6}$ & Guarani & 0,2966022 & 26 & 1,11559520 \\
$\mathbf{1 0 0 4}$ & Passaredo & 0,1986718 & 32 & 1,15942172 \\
$\mathbf{1 0 1 0}$ & Guarani & 0,1969560 & 20 & 1,01367144 \\
$\mathbf{1 0 0 5}$ & Guarani & 0,1820838 & 23 & 1,23206052 \\
$\mathbf{1 0 0 5}$ & Passaredo & 0,1687840 & 29 & 0,97596516 \\
$\mathbf{1 0 0 6}$ & Passaredo & 0,0422025 & 11 & 0,62058871 \\
$\mathbf{1 0 0 8}$ & Guarani & 0,0131267 & 18 & 0,92688214 \\
\hline
\end{tabular}

Tabela 5.22: As dez turmas com maiores médias do fator NB.

\begin{tabular}{llclr}
\hline \multicolumn{5}{c}{ Religiosidade Intrínseca (RI) } \\
\hline Turma & Escola & Média & N & Desvio Padrão \\
$\mathbf{1 0 0 6}$ & Passaredo & 0,6378367 & 13 & 0,72502016 \\
$\mathbf{1 0 0 5}$ & Guarani & 0,3855322 & 24 & 0,97486689 \\
$\mathbf{1 0 0 1}$ & Passaredo & 0,3116521 & 17 & 0,96110508 \\
$\mathbf{1 0 0 2}$ & Passaredo & 0,2987605 & 25 & 1,04700018 \\
$\mathbf{1 0 0 6}$ & Guarani & 0,2752990 & 25 & 0,88149864 \\
$\mathbf{1 0 1 7}$ & Guarani & 0,2723945 & 25 & 0,88455480 \\
$\mathbf{1 0 0 5}$ & Passaredo & 0,1727389 & 32 & 1,28049925 \\
$\mathbf{1 0 0 3}$ & Passaredo & 0,1654595 & 19 & 0,97268934 \\
$\mathbf{1 0 0 3}$ & Guarani & $-0,0253200$ & 28 & 1,11376049 \\
$\mathbf{1 0 0 4}$ & Passaredo & $-0,0337771$ & 33 & 1,06007584 \\
\hline
\end{tabular}

Tabela 5.23: As dez turmas com maiores médias de RI.

\begin{tabular}{|c|c|c|c|c|}
\hline \multicolumn{5}{|c|}{ Religiosidade Organizacional (RO) } \\
\hline Turma & Escola & Média & $\mathbf{N}$ & Desvio Padrão \\
\hline 1002 & Passaredo & 0,7058708 & 26 & 0,88563406 \\
\hline 1001 & Passaredo & 0,6224068 & 17 & 1,02553614 \\
\hline 1005 & Guarani & 0,3451986 & 25 & 0,97590127 \\
\hline 1005 & Passaredo & 0,2791709 & 31 & 1,08354126 \\
\hline 1007 & Guarani & 0,2519792 & 24 & 1,05154735 \\
\hline 1006 & Passaredo & 0,2481650 & 13 & 1,01506854 \\
\hline 1004 & Passaredo & 0,2384561 & 33 & 0,98604511 \\
\hline 1006 & Guarani & 0,2252797 & 26 & 1,01649847 \\
\hline 1003 & Passaredo & 0,1397610 & 19 & 1,00928597 \\
\hline 1003 & Guarani & 0,0177338 & 29 & 1,00706287 \\
\hline
\end{tabular}

Tabela 5.24: As dez turmas com maiores médias de RO. 


\begin{tabular}{llclr}
\hline \multicolumn{5}{c}{ Religiosidade Não Organizacional (RNO) } \\
\hline Turma & Escola & Média & N & Desvio Padrão \\
$\mathbf{1 0 0 1}$ & Passaredo & 0,5331652 & 17 & 0,96320723 \\
$\mathbf{1 0 0 2}$ & Passaredo & 0,3324135 & 26 & 0,88117569 \\
$\mathbf{1 0 0 3}$ & Guarani & 0,2931862 & 29 & 0,84545421 \\
$\mathbf{1 0 0 7}$ & Guarani & 0,2139143 & 24 & 1,00608231 \\
$\mathbf{1 0 0 5}$ & Guarani & 0,1503986 & 25 & 0,93923206 \\
$\mathbf{1 0 0 8}$ & Guarani & 0,1112149 & 18 & 0,89699185 \\
$\mathbf{1 0 0 4}$ & Passaredo & 0,1083422 & 33 & 0,98456221 \\
$\mathbf{1 0 2 5}$ & Guarani & 0,0374820 & 27 & 1,13068481 \\
$\mathbf{1 0 1 7}$ & Guarani & 0,0366394 & 25 & 0,97306873 \\
$\mathbf{1 0 0 5}$ & Guarani & $-0,0053094$ & 32 & 1,05039355 \\
\hline
\end{tabular}

Tabela 5.25: As dez turmas com maiores médias de RNO.

\begin{tabular}{llllr}
\hline \multicolumn{5}{c}{ Entendimento de evolução } \\
\hline Turma & Escola & Média & N & Desvio Padrão \\
\hline $\mathbf{1 0 0 3}$ & Passaredo & $-0,4378216$ & 20 & 0,85491414 \\
$\mathbf{1 0 0 4}$ & Passaredo & $-0,4338327$ & 34 & 0,92238680 \\
$\mathbf{1 0 1 1}$ & Guarani & $-0,3746878$ & 29 & 0,96545655 \\
$\mathbf{1 0 1 5}$ & Guarani & $-0,2886389$ & 25 & 0,75611807 \\
$\mathbf{1 0 0 6}$ & Passaredo & $-0,2343906$ & 13 & 1,23804150 \\
$\mathbf{1 0 0 9}$ & Guarani & $-0,2343906$ & 29 & 1,10238343 \\
$\mathbf{1 0 0 1}$ & Passaredo & $-0,2343906$ & 17 & 0,89704629 \\
$\mathbf{1 0 0 8}$ & Guarani & $-0,1590458$ & 18 & 0,65327237 \\
$\mathbf{1 0 2 4}$ & Guarani & $-0,1496277$ & 16 & 0,64923444 \\
$\mathbf{1 0 1 4}$ & Guarani & $-0,1300670$ & 26 & 0,99090926 \\
\hline
\end{tabular}

Tabela 5.26: As dez turmas com menores médias de Entendimento da Evolução.

\begin{tabular}{lllrr}
\hline \multicolumn{5}{c}{ Evangélicos por Turma } \\
\hline Turma & Escola & N & Evangélicos & Outros \\
\hline $\mathbf{1 0 0 1}$ & Passaredo & 17 & $82,4 \%$ & $17,6 \%$ \\
\hline 1002 & Passaredo & 26 & $69,2 \%$ & $30,8 \%$ \\
\hline $\mathbf{1 0 0 4}$ & Passaredo & 33 & $48,5 \%$ & $51,5 \%$ \\
$\mathbf{1 0 0 3}$ & Passaredo & 20 & $45,0 \%$ & $55,0 \%$ \\
$\mathbf{1 0 0 5}$ & Passaredo & 32 & $43,8 \%$ & $56,3 \%$ \\
$\mathbf{1 0 0 6}$ & Guarani & 26 & $38,5 \%$ & $61,5 \%$ \\
$\mathbf{1 0 0 7}$ & Guarani & 24 & $37,5 \%$ & $62,5 \%$ \\
$\mathbf{1 0 0 5}$ & Guarani & 25 & $36,0 \%$ & $64,0 \%$ \\
$\mathbf{1 0 1 7}$ & Guarani & 25 & $32,0 \%$ & $68,0 \%$ \\
$\mathbf{1 0 1 4}$ & Guarani & 26 & $30,8 \%$ & $69,2 \%$ \\
\hline
\end{tabular}

Tabela 5.27: As dez turmas com maiores frequências de estudantes evangélicos.

Como discutimos anteriormente, apenas nas turmas1003 e 1008, do Colégio Guarani, e 1001, do Colégio Passaredo, observamos o questionamento em sala de aula das teorias científicas sobre origem e evolução dos seres vivos por 
parte dos estudantes. A turma 1001 do Passaredo está entre as primeiras em todas as tabelas acima, enquanto a 1003 do Guarani está presente na tabela 5.21 (AC, sexto lugar), 5.23 (RI, nono), 5.24 (RO, décimo) e 5.25 (RNO, terceiro).A turma 1008 do Guarani, que está presente apenas na 5.22 (NB, décimo), 5.25 (RNO, sexto) e 5.26 (Entendimento, oitavo), mas nunca entre as cinco primeiras colocações.

É preciso destacar, ainda, que o surgimento do conflito na turma 1008, no entanto, foi bem distinto da turma 1001 e 1003. Na primeira, o professor P1 desvalorizou a crença religiosa de uma estudante de diversas maneiras, o que provocou sua reação. Já na segunda, a professora P3 procurou desenvolver a discussão pautando-se em problematizar argumentos expostos por uma estudante que tomou a iniciativa de questionar os conteúdos de evolução. Na última, o docente P7 usava os dinossauros como exemplo para explicar evolução e algumas alunas o interpelaram dizendo que não acreditavam nesses animais porque não os tinham visto.

Uma vez que o conflito explícito em sala de aula se mostra raro, mesmo nas condições que, em princípio, lhe seriam mais propícias, isto pode indicar que os alunos que rejeitam a teoria evolutiva optam por permanecer em silêncio, evitando a exposição e o desgaste com seus colegas e o professor, algo que está expresso nas falas de A4, A7, A12 e A19, analisados ao longo deste capítulo e do anterior. Isto também parece ser evidenciado pelas falas de P2, P3, P4 e P5 de que não têm ou tiveram poucos conflitos em sala.

Esse conflito presente, porém, velado, se configura como um desafio para o ensino que visa o entendimento da teoria evolutiva respeitando as crenças religiosas dos estudantes. Se um dos pressupostos para a educação em uma perspectiva intercultural que aqui defendemos é o diálogo (ANDRADE, 2009; CORTINA, 1996, 2008; HABERMAS, 1984, 1989), é imprescindível que diferentes visões de mundo possam e queiram ser expressas pelos participantes. Nesse sentido, nossa pesquisa aponta para a importância de se abordar não apenas os conteúdos de evolução e origem da vida, mas também explorar-se discursos e crenças religiosas que os estudantes podem vir a ter. Contrastando-as explicitamente e apontando os limites de determinadas explicações literalistas sobre o mundo natural e do cientificismo sobre a vida nas sociedades 
contemporâneas, poder-se-ia dar um passo mais significativo para o ensino de biologia.

\subsection{0}

\section{Conclusão}

Em síntese, as observações realizadas, as entrevistas dos sujeitos de pesquisa e os dados obtidos nos questionários indicam que, embora alguns estudantes possam ter crenças que estão em profundo conflito com o conteúdo ensinado, é pouco provável que se manifestem. O principal argumento utilizado gira em torno da ideia de que todos têm ideias próprias, com frequência, diferentes entre si, e que, portanto, não haveria razão para discuti-las. Esses argumentos nos parecem preocupantes, dado que reforçam posturas de pouca abertura a posições distintas da própria e não favorecem a construção e análise de argumentos para sustentá-las.

As estratégias didáticas e atitudes dos professores em sala são heterogêneas, mas se relacionam diretamente com as suas concepções pessoais. Enquanto P1 se mostra fechado a concepções criacionistas de seus estudantes, P4 anuncia sua própria tentativa de conciliar seus conhecimentos em biologia com suas crenças religiosas e P2 e P3 procuram analisar os argumentos expostos por seus alunos até o momento em que estes atingem dúvidas que elas mesmas possuem. Já P5, P6 e P7 não tiveram muitos estudantes se manifestando em suas aulas, o que limita possíveis tentativas de discussão. Essa diversidade parece indicar que a tensão, com distintas variações, entre evolução e criacionismo é uma constante entre todos os professores pesquisados e toda abordagem parece encontrar limitações. 


\section{7.}

\section{Considerações finais}

Aproximando-nos do final deste trabalho, é pertinente voltar aos objetivos propostos e hipóteses suscitadas, refletindo-se como o tentamos explorá-los. Faremos, inicialmente, uma síntese das principais ideias aqui desenvolvidas e procuraremos, por fim, indicar possíveis contribuições para pesquisas futuras.

No capítulo introdutório desta tese, procuramos delinear os contornos gerais de nosso tema e questão de pesquisa. As tensões entre criacionismo e evolução estão inseridas em um contexto mais amplo das discussões entre ciência e religião (BARBOUR, 2000). Mesmo que o senso comum as entenda como profundas inimigas, há evidências de que esse relacionamento é bastante complexo (BROOKE, 1991). Esse é uma temática muito característica dos EUA, todavia, nas últimas décadas, tem se estendido a outros contextos, inclusive o Brasil (NUMBERS, 2006). Em nosso país, alguns grupos evangélicos pentecostais e neopentecostais têm demonstrado maior resistência à teoria evolutiva e maior defesa do criacionismo do que outros grupos religiosos (MALAFAIA, 2009). Assim, faz sentido investigar o ensino de evolução em contexto de forte presença dessas religiões.

Passando ao segundo capítulo, "Diálogos com a teoria", procuramos apresentar e discutir os principais referenciais teóricos que nortearam esta pesquisa. Destacamos a importância da evolução para o campo acadêmico e a disciplina escolar de biologia, ressaltando, como disse Dobzhansky (1973), que nada faz sentido em biologia, exceto à luz da evolução. No entanto, como ampla gama de autores, defendemos a perspectiva de que o objetivo do ensino de evolução deve ser o seu entendimento de conceitos científicos e não a mudança da crença religiosa do estudante (COBERN, 1994, 2000; EL-HANI; MORTIMER, 2007; REISS, 2008，2009; SMITH; SIEGEL; MCINERNEY, 1995; SMITH; SIEGEL, 2004; SMITH, 2010a). Nesse sentido, exploramos ainda o crescimento e as características dos evangélicos pentecostais e neopentecostais no Brasil e os impactos dessas mudanças sobre o cenário religioso em nosso país, bem como os 
impactos na educação e, principalmente, nas aulas de biologia. Assim, estabelecemos uma discussão sobre como a interculturalidade e os mínimos éticos podem ajudar a construir uma proposta de educação voltada para a tolerância ética e epistemológica e para um ensino de biologia que respeite as crenças religiosas dos estudantes. Partindo desse pressuposto, baseamo-nos no trabalho de Habermas(1984, 1989)e France(2011) para propor um modelo de espaço de busca, fundamentado no discurso como uma possibilidade para o ensino, especialmente para a temática da evolução em aulas de biologia.

No terceiro capítulo, "Campo e sujeitos de pesquisa", apresentamos o campo de pesquisa, detalhando o ensino de biologia na rede estadual, as principais características dos colégios Guarani e Passaredo, bem como dos professores e estudantes pesquisados. Ressaltamos, também, as diferenças da presença religiosa entre as duas escolas, frisando a maior quantidade de educandos e igrejas pentecostais e neopentecostais na escola nilopolitana e arredores.

Já no quarto capítulo, "Concepções dos professores sobre criacionismo e evolução", analisamos as concepções dos docentes pesquisados sobre evolução e criacionismo, com base nos dados coletados nas entrevistas e nas observações das aulas. Encontramos um cenário diverso e complexo, desde professores que não aceitavam o criacionismo, como P1 e P7, a professores que tentavam concilia-los, lançando mão de diferentes elementos para justificar ora suas crenças religiosas, ora a teoria evolutiva, como P2, P3 e P6, passando por docentes que articulavam ideias muito distintas entre si em formulações bastante originais, como P4 e P5.

Em nosso quinto capítulo, "Concepções dos(as) estudantes sobre criacionismo e evolução", estudamos as concepções dos discentes sobre esses temas através da análise das entrevistas e dos questionários. Vimos que há um gradiente de concepções sobre a origem e evolução dos seres humanos e dos demais seres vivos. Os estudantes evangélicos entrevistados tenderam a manifestar posições literalistas, contudo, também entre eles houve diversidade de respostas. Em relação aos questionários, construímos, por análise fatorial exploratória, dois índices ligados à aceitação da evolução: fator de aceitação dos aspectos científicos da evolução (AC) e fator de aceitação da narrativa bíblica para a origem da vida (NB). As análises revelaram não haver diferença significativa entre os grupos religiosos para o primeiro, mas sim para o segundo. Em relação ao entendimento da evolução, também construímos um índice que se 
mostrou estatisticamente diferente entre as duas escolas, mas não entre os grupos religiosos. Já a religiosidade foi medida em três índices, seguindo o DUREL (KOENIG; BÜSSING, 2010): Religiosidade Intrínseca (RI), Religiosidade Organizacional (RO) e Religiosidade Não Organizacional (RNO). O Colégio Passaredo apresentou maiores resultados do que o Colégio Guarani para os três índices, bem como os evangélicos quando comparados aos outros grupos religiosos. Foram realizadas, adicionalmente, correlações entre estes índices e outras variáveis. Os fatores AC e NB apresentaram correlação com os fatores RI, RO e RNO e com o fato de o estudante ser evangélico. Já o entendimento da evolução apresentou correlação apenas com AC, com o fato de o estudante ser branco, pardo, fazer o dever de casa e o professor corrigir o dever de casa.

No sexto e último capítulo, “As relações entre religião, ciência, criacionismo e evolução em sala de aula", procuramos articular a análise das observações em sala de aula com as falas de professores e estudantes pesquisados. Percebemos que questionamentos explícitos da teoria evolutiva são raros e apenas em uma turma, 1008, do professor P1, observamos uma discussão ríspida acerca deste tema. Procuramos, também, aplicar o nosso modelo aos casos estudados, afim de identificar os limites e potencialidades de cada abordagem. Assim, além do perfil e das atitudes dos educandos, as crenças dos professores são fundamentais para entender como abordam as relações entre criacionismo e evolução em suas aulas. Enquanto P1 desvalorizou a crença de sua aluna, P4 expressou a ideia de que ciência e religião se encontram, P2, P3 e P5 demonstraram certa insegurança e P6 e P7 contrastaram essas duas formas de conhecimento, mas com poucas coesões por parte dos estudantes.

Com relação aos objetivos estabelecidos, o primeiro consistia em "Identificar as relações, os conflitos e as aproximações entre a evolução biológica e o criacionismo em aulas de biologia em um contexto de forte presença pentecostal e neopentecostal". Os dados das observações mostram que essas relações são complexas e estão intrinsecamente ligadas às próprias concepções dos professores sobre o tema. Conflitos e aproximações são promovidos ou evitados de acordo com as crenças pessoais dos docentes: aqueles que veem religião e ciência como separados e inconciliáveis tendem a expressar isso em suas aulas, até mesmo em tom de sarcasmo. Já aqueles que buscam conciliar sua fé religiosa com os seus conhecimentos sobre biologia, apresentam ciência e 
religião como plenamente compatíveis, desviam-se de qualquer embate ou promovem o debate até o limite de suas próprias dúvidas. Em diversas oportunidades, os professores demonstraram ter clara preocupação especificamente com os estudantes evangélicos.

O segundo objetivo era "Analisar como o(a) professor(a) de biologia e os(as) estudantes lidam com possíveis conflitos em sala de aula em torno dos temas de evolução e criacionismo". Como percebemos em nossas observações, questionamentos da teoria evolutiva neodarwinista por parte dos estudantes foram raros e em apenas uma situação presenciamos um conflito evidente e que gerou incômodo entre os educandos. Essa "não-demonstração" do conflito não é sinônima de sua inexistência. As entrevistas e os dados dos questionários apontam no sentido de haver, por parte de determinados alunos, uma forte resistência às teorias científicas para a origem e evolução da vida. Essa ausência faz com que os professores declarem que não têm conflitos com alunos de crenças criacionistas e que, como disse P4, essa seja uma questão muito mais para quem está fora da escola do que dentro.

Este ponto nos leva ao terceiro objetivo: "Compreender que características das crenças ou da ausência de crenças de professores(as) e estudantes podem contribuir ou se tornarem obstáculos para o processo de ensino-aprendizagem da teoria da evolução". Uma vez que os estudantes criacionistas optam por permanecer em silêncio - ou são levados a tal postura durante as aulas, cria-se um obstáculo para o diálogo entre eles e o professor. Se não se sentem à vontade para expressar suas visões, não será possível ao docente compreendê-las e usá-las para contrastar as diferenças entre ciência e religião. Paralelamente, se o docente não explora essas diferenças porque ele mesmo possui dúvidas sobre suas crenças pessoais, o processo de ensino-aprendizagem também é afetado, já que dificilmente conseguirá superar suas próprias contradições.

Com relação às hipóteses levantadas na pesquisa, a primeira dizia que "estudantes que professam uma religião evangélica de orientação pentecostal ou neopentecostal tendem a identificar conflitos entre suas crenças e a teoria da evolução". Essa hipótese foi confirmada quando observamos que os estudantes evangélicos entrevistados expressam, em sua maioria, forte resistência à teoria evolutiva. Além disso, os dados obtidos através do questionário indicam que é 
esse grupo religioso que possui maior índice de aceitação da narrativa bíblica para a origem dos seres vivos (NB).

A segunda hipótese dizia "esses conflitos estão mais ligados a diferenças entre determinadas afirmações científicas e elementos da moral religiosa do que a diferenças epistemológicas entre ciência e religião". Essa hipótese também se mostrou plausível tendo em vista que não observamos conflitos com relação a nenhum outro conteúdo abordado ao longo do ano e, mais importante, não houve diferença significativa entre os grupos de religião com relação ao fator de aceitação dos aspectos científicos da teoria evolutiva (AC). Assim, como Evans (2011) defende, os estudantes não descartam a ciência como um todo, mas apenas os conhecimentos que entram em choque com suas crenças religiosas.

Já a terceira hipótese afirmava que "esses conflitos fazem com que os educandos realizem um percurso compreensivo tensionado entre moral religiosa e conhecimento científico em relação à compreensão da teoria evolutiva". Essa afirmação se aplica parcialmente aos dados por nós encontrados. Uma vez que não houve diferença estatisticamente significativa no entendimento da teoria evolutiva entre os grupos religiosos estudados. Aparentemente, estudantes evangélicos pentecostais e neopentecostais não teriam mais dificuldades de compreender a teoria evolutiva do que os que pertencem a outras religiões. No entanto, alguns alunos entrevistados demonstram dificuldades em articular suas crenças religiosas e os conteúdos de evolução. Veem ambos como plausíveis, mas ficam em dúvida de como conciliá-los.

Pensando em pesquisas futuras, acreditamos que o presente trabalho contribui no sentido de ressaltar a complexidade das concepções de professores de biologia. Para além de um cenário "preto no branco" em que ou se é "evolucionista" ou "criacionista", há um amplo espectro de "cinzas" que influencia diretamente na construção das aulas e no relacionamento com os educandos. O mesmo se aplica aos discentes, mesmo os evangélicos. Ainda que estes demonstrem maior resistência à teoria evolutiva do que outros grupos religiosos, há certa diversidade interna que precisa ser considerada e vista como ponto de partida para um investimento no entendimento da teoria evolutiva. Nesse sentido, destacamos também a importância de se estudar a religiosidade em suas diferentes dimensões e não apenas as denominações religiosas. Como procuramos discutir, pensar a religiosidade intrínseca, a organizacional e a não organizacional 
é importante para se aprofundar a compreensão das visões dos educandos sobre as relações entre evolução e criacionismo e, em sentido mais amplo, ciência e religião.

Apontamos, ainda, para a necessidade de mais estudos que explorem a sala de aula em si e, principalmente, estratégias didáticas que estejam voltadas para o ensino de evolução com o objetivo de promover seu entendimento e não a mudança de crença. Nesse sentido, talvez seja preciso atuar mais fortemente na formação de professores não só para que estes compreendam o papel das crenças religiosas para a identidade e visão de mundo de seus alunos, como também para que reconheçam seu compromisso com os conhecimentos científicos e não descaracterizem a teoria evolutiva em sala de aula para acomodá-la às suas próprias crenças. As aulas observadas nesta pesquisa foram, praticamente em sua totalidade, frontais e expositivas. É possível que outras estratégias como aulas práticas, em laboratório ou não, saídas de campo, visita a museus, pesquisas bem planejadas, dentre outras, possam auxiliar nesse sentido. Tais atividades não precisariam ser voltadas especificamente para o ensino da teoria evolutiva, mas, ao explorar-se a natureza da ciência, amplia-se a compreensão do pensamento científico e suas diferenças para outras formas de conhecimento.

Além disso, ressaltamos que diferentes grupos religiosos, organizações e políticos têm promovido o criacionismo em vários contextos no Brasil ao longo dos últimos anos. Seja na forma de projetos de lei que visam inserir o criacionismo nos currículos escolares (BRASIL, 2014), seja realizando congressos "científicos" sobre o design inteligente (LOPES, 2014), há diversas tentativas para questionar-se a teoria evolutiva em favor de ideias que, como vimos, foram seguidamente rejeitadas como científicas. Como buscamos ressaltar ao longo de todo este trabalho, é preciso respeitar-se a liberdade de crença e nisto inclui-se o criacionismo em suas múltiplas formas. No entanto, isto não o torna científico, nem uma alternativa plausível à evolução, enquanto uma construção científica. Portanto, não há razões epistemológicas suficientes para inseri-lo em currículos de ciências. Mas, com base no modelo de espaço de busca, parece haver razões pedagógicas e didáticas que a levem a considerá-lo nas aulas de biologia, principalmente em contextos com forte presença pentecostal visando o reconhecimento da importância das crenças religiosas dos estudantes, a fim de melhor cumprir os objetivos compartilhados pela comunidade acadêmica e escolar 
para o ensino sobre a origem e a evolução da vida. Isto é, ter por objetivo o entendimento dos conteúdos científicos, mas evitando-se o cientificismo.

Por fim, destacamos a pertinência de que mais pesquisas quantitativas sobre a aceitação e entendimento da teoria evolutiva sejam conduzidas em nosso país. Muito comum em outros contextos, são raros os estudos no Brasil que fazem uso de questionários e análises que busquem um olhar em uma perspectiva mais "macro" que auxiliem a contextualizar os dados obtidos por metodologias qualitativas. Estas, certamente, possuem seu valor, ao evidenciar a complexidade de crenças religiosas e de suas relações com os conhecimentos sobre evolução. Todavia, generalizações podem ser feitas com muita cautela quando se trata de dados qualitativos, algo que os dados quantitativos oferecem de maneira mais adequada, ainda que isso nunca signifique uma certeza absoluta.

Esperamos que esta tese contribua para uma discussão mais aprofundada não só das relações entre evolução e criacionismo, mas também do relacionamento entre visões de mundo distintas, entre crenças religiosas e o lugar da religião nas sociedades contemporâneas. Em tempos atuais, em que a tolerância parece rara e o diálogo uma utopia, esses dois elementos tornam-se ainda mais imperativos para contextos multiculturais e pluralistas. Para esta tarefa, parafraseando Paulo Freire, a educação sozinha pode não ser suficiente, mas sem ela tampouco lograremos êxito. 


\section{8.}

\section{Referências}

ALMEIDA, A. V. DE; FALCÃO, J. T. D. R. A estrutura histórico-conceitual dos programas de pesquisa de Darwin e Lamarck e sua transposição para o ambiente escolar. Ciência \& Educação (Bauru), v. 11, n. 1, p. 17-32, 2005.

ALMEIDA, A. V. DE; FALCÃO, J. T. D. R. As teorias de Lamarck e Darwin nos livros didáticos de Biologia no Brasil. Ciência \& Educação (Bauru), v. 16, n. 3, p. 649-665, 2010.

ALMEIDA, D. F. DE. Concepções de Alunos do Ensino Médio sobre a Origem das Espécies. Ciência \& Educação, v. 18, n. 1, p. 143-154, 2012.

ALMEIDA, R. DE. A Igreja Universal e seus demônios : um estudo etnográfico. São Paulo: Ed. Terceiro Nome, 2009.

ANDRADE, M. Tolerar é pouco? Pluralismo, mínimos éticos e práticas pedagógicas. Petrópolis: DP et alli, 2009.

ANDRADE, M.; TEIXEIRA, P. P. A escola num mundo secular e religioso : Poderia ser a tolerância uma alternativa? Teias, v. 15, n. 36, p. 61-79, 2014.

ANNAS, G. J. Legal issues in medicine Intelligent Judging - Evolution in the Classroom. Area, n. 1960, p. 2277-2281, 2006.

AYALA, F. J. Science, evolution, and creationism. [s.l: s.n.]. v. 105

BANKS, J. A. An introduction to multicultural education. Boston: Allyn and Bacon, 1999.

BARBOSA, M. L. D. O. Desigualdade e desempenho: uma introdução à sociologia da escola brasileira. Belo Horizonte: Argvmentvm, 2009.

BARBOUR, I. G. When science meets religion / Ian G. Barbour. [San Francisco]: HarperSan Francisco, 2000.

BARNES, R. M.; CHURCH, R. A. Proponents of Creationism but not Proponents of Evolution Frame the Origins Debate in Terms of Proof. Science \& Education, v. 22, n. 3, p. 577-603, 18 mar. 2012.

BEAUD, S.; WEBER, F. Guia para a pequisa de campo: produzir e analisar dados etnográficos. Petrópolis: Vozes, 2007. 
BEHE, M. J. A caixa preta de Darwin: $O$ desafio da bioquímica à teoria da evolução. Rio de Janeiro: Jorge Zahar Editor, 1997.

BERGER, P. A dessecularização do mundo: uma visão global. Religião e Sociedade, v. 21, n. 1, p. 9-24, 2001.

BERGER, P. L. O dossel sagrado: elementos para uma teoria sociológica da religião. 1985.

BLACKWELL, W. H.; POWELL, M. J.; DUKES, G. H. The problem of student acceptance of evolution. Journal of Biological Education, v. 37, n. 2, p. 58-67, 2003.

BLANCKE, S. et al. The Implications of the Cognitive Sciences for the Relation Between Religion and Science Education: The Case of Evolutionary Theory. Science \& Education, v. 21, n. 8, p. 1167-1184, 20 out. 2011.

BOBBIO, N. Elogio da serenidade. São Paulo: Unesp, 2002.

BOUJAOUDE, S. et al. Muslim Egyptian and Lebanese Students' Conceptions of Biological Evolution. Science \& Education, v. 20, n. 9, p. 895-915, 26 fev. 2011.

BRANDÃO, C. R. Os deuses do povo : um estudo sobre a religião popular. São Paulo: Livraria Brasiliense Editora, 1980.

BRASIL. Parâmetros Curriculares Nacionais Ensino Médio Parte III Ciências da Natureza, Matemática e suas Tecnologias. Brasília: MEC, 1998.

BRASIL. Orientações Curriculares para o Ensino Médio: Ciências da Natureza, matemática e suas tecnologias. [s.l: s.n.]. v. 2

BRASIL. Projeto de Lei No. 8099: Ficam inseridos na grade curricular das Redes Pública e Privada de Ensino, Conteúdos sobre criacionismo. . 2014.

BRAUN, V.; CLARKE, V. Braun, V ., Clarke, V .Using thematic analysis in psychology., 3:2 (2006), 77-101. Qualitative Research in Psychology, v. 3, p. 77-101, 2006.

BROOKE, J. H. Science and Religion: Some Historical Perspectives. [s.l: s.n.].

BSGI. Missão e Visão. Disponível em:

<http://www.bsgi.org.br/quemsomos/visao_e_missao/>. Acesso em: 26 maio. 2015.

CANDAU, V. M. Direitos humanos, educação e interculturalidade: as tensões entre igualdade e diferença Revista Brasileira de Educação scielo , , 2008.

CANDAU, V. M. F. Sociedade, cotidiano escolar e cultura(s): uma aproximação Educação \& Sociedade scielo , , 2002.

CAPUTO, S. Educação nos terreiros : e como a escola se relaciona com crianças de candomblé. Rio de Janeiro: Pallas, 2012. 
CARDOSO, A. Dimensões Básicas da Religiosidade Belo-Horizontina. Estudos Avancados, v. 18, n. 52, p. 63-75, 2004.

CARVALHO, C. P. DE et al. Gestão e Desempenho Escolar: um estudo nas redes municipais da Região Metropolitana do Rio de Janeiro a partir dos resultados da Prova Brasil 2009III Congresso Ibero Americano de Política e Administração da Educação. Anais...Zaragoza: Biblioteca ANPAE - Cadernos ANPAE, 2012

CARVALHO, G. S.; CLÉMENT, P.; LYON, U. DE. Projecto “ Educação em biologia , educação para a saúde e educação ambiental para uma melhor cidadania ": análise de manuais escolares e concepções de professores de 19 países ( europeus , africanos e do próximo oriente ) “ Biology, Health and Environmen. v. 7, 2007.

CAVALIERE, A. M. O mal-estar do ensino religioso nas escolas públicas. Cadernos de Pesquisa, v. 37, n. 131, p. 303-332, 2007.

CHALMERS, A. F. What is this thing called science? [s.l: s.n.]. v. 73

COBERN, W. W. Point : Belief, Understanding, and the Teaching of Evolution. v. 3, n. 5, p. 583-590, 1994.

COBERN, W. W. Worldview theory and conceptual change in science education. Science Education, v. 80, n. 5, p. 579-610, set. 1996.

COBERN, W. W. The Nature of Science and the Role of Knowledge and Belief. Science and Education, v. 9, n. 3, p. 219-246, 2000.

COBERN, W. W.; LOVING, C. C. Defining "science" in a multicultural world: Implications for science education. Science Education, v. 85, n. 1, p. 50-67, 2001.

COIMBRA, R. L.; SILVA, J. Ensino de evolução biológica e a necessidade de formação continuadaVI Encontro Nacional de Pesquisa em Educação em Ciências (ENPEC). Anais...Florainópolis: ABRAPEC, 2007

CORTINA, A. Ética civil e religião. São Paulo: Paulinas, 1996.

CORTINA, A. Cidadãos do Mundo. São Paulo: Loyola, 2005.

CORTINA, A. Aliança e contrato. São Paulo: Loyola, 2008.

CPS/FGV. Novo mapa das religiões. Rio de Janeiro: FGV, 2011.

CUNHA, L. A. Sintonia oscilante: religião, moral e civismo no Brasil 1931/1997. Cadernos de Pesquisa, v. 37, n. 131, p. 285-302, 2007.

CUNHA, L. A. A luta pela ética no ensino fundamental: religiosa ou laica? Cadernos de Pesquisa, v. 39, n. 137, p. 401-419, 2009.

DAGHER, Z. R.; BOUJAOUDE, S. Students' perceptions of the nature of 
evolutionary theory. Science Education, v. 89, n. 3, p. 378-391, maio 2005.

DAWKINS, R. The Blind Wathcmaker. Why the Evidence of Evolution Reveals a Universe without Design. [s.l: s.n.].

DO CARMO, V. A.; BIZZO, N.; MARTINS, L. A. P. Alfred Russel Wallace e o princípio de seleção natural. Filosofia e História da Biologia, v. 4, p. 209-233, 2009.

DOBZHANSKY, T. Nothing in Biology Makes Sense except in Light of Evolution. American Biology Teacher, v. 35, n. 3, p. 125-129, 1973.

DORVILLÉ, L. F.; SELLES, S. E. Conflitos e tensões entre ciência e religião nas visões de mundo de alunos evangélicos de uma licenciatura em ciências biológicasVIII Congreso Internacioanl sobre investigación en la didáctica de las ciencias. Anais...Barcelona: 2009

EL-HANI, C. N.; MORTIMER, E. F. Multicultural education, pragmatism, and the goals of science teaching. Cultural Studies of Science Education, v. 2, n. 3, p. 657-702, 2007.

EL-HANI, C. N.; SEPULVEDA, C. The relationship between science and religion in the education of protestant biology preservice teachers in a Brazilian university. Cultural Studies of Science Education, v. 5, n. 1, p. 103-125, 2010.

ENGLER, S. Tipos de Criacionismos Cristãos. v. 56, n. 1986, p. 83-107, 2007.

EVANS, E. M.; LEGARE, C. H.; ROSENGREN, K. Engaging multiple epistemologies: Implications for science education. In: TAYLOR, R. S.; FERRARI, M. (Eds.). . Epistemology and Science Education: Understanding the Evolution Vs. [s.1.] Routledge, 2011.

EVANS, J. H. Epistemological and Moral Conflict Between Religion and Science. Journal for the Scientific Study of Religion, v. 50, n. 4, p. 707-727, 2011.

EVANS, J. H.; EVANS, M. S. Religion and Science: Beyond the Epistemological Conflict Narrative. Annual Review of Sociology, v. 34, n. 1, p. 87-105, ago. 2008.

FIELD, A. Descobrindo a estatística usando o SPSS. 2. ed. Porto Alegre: Artmed, 2009.

FINLAYSON, G. Habermas: a very short introduction. Schizophrenia, v. 125, n. 125, p. 156, 2005.

FONSECA, L. Religião popular: $O$ que a escola tem a ver com isso? Pistas para repensar o ensino de ciências. [s.l.] Universidade Federal do Rio de Janeiro, 2005.

FORQUIN, J. C. Escola e cultura: as bases sociais e epistemológicas do conhecimento escolar. Porto Alegre: Artmed, 1993. 
FRANCE, B. How Post Normal views of science have contributed to a model of communication about biotechnology. Futures, v. 43, n. 2, p. 166-172, 2011.

FRESTON, P. Protestantes e política no Brasil: da Constituinte ao impeachment. [s.1.] Unicamp, 1993.

FUTUYMA, D. J. Evolution. Sunderland, Mass: Sinauer Associates, 2005.

GEERTZ, C. O beliscão do destino: a religião como experiência, sentido, identidade e poder. In: Nova luz sobre a antropologia. Rio de Janeiro: Jorge Zahar Editor, 2001. p. 140-165.

GIUMBELLI, E. Símbolos religiosos em controvérsias. Rio de Janeiro: Jorge Zahar Editor, 2014.

GOULD, S. J. Rocks of ages : science and religion in the fullness of life. New York: Ballantine Pub. Group, 1999.

GOVERNO DO ESTADO DO RIO DE JANEIRO. Policiais militares farão segurança em escolas públicas do estado. Disponível em:

<http://www.rj.gov.br/web/seseg/exibeconteudo?article-id=907265>.

HABERMAS, J. The theory of communicative action. Book, v. 1, n. 1, p. v., 1984.

HABERMAS, J. Conciência Moral e Agir Comunicativo, 1989.

HENRY, J. A Revolução Científica. 1. ed. Rio de Janeiro: Jorge Zahar Editor, 1998.

HESS, D. Controversy in the classroom : the democratic power of discussion. New York: Routledge, 2009.

IBGE. Censo Demográfico 2010: Características gerais da população, religião e pessoas com deficiência. Rio de Janeiro: IBGE, 2012.

IBM. Post hoc comparisons for the Kruskal-Wallis test - United States.

Disponível em: <http://www-

01.ibm.com/support/docview.wss?uid=swg21477370>. Acesso em: 15 dez. 2015.

JACOB, C. R. et al. Atlas da filiação religiosa e indicadores sociais do Brasil. Rio de Janeiro; São Paulo: Ed. PUC-Rio; Loyola, 2003.

JACOB, C. R. et al. Religião e Território no Brasil : 1991 / 2010. [s.l: s.n.].

KARDEC, A. A Gênese. [s.l: s.n.].

KOENIG, H. G.; BÜSSING, A. The Duke University Religion Index (DUREL): A Five-Item Measure for Use in Epidemological Studies. Religions, v. 1, n. 1, p. 78-85, 2010. 
KOENIG, H.; PARKERSON G.R., J.; MEADOR, K. G. Religion index for psychiatric researchAmerican Journal of Psychiatry, 1997.

LEMOS, F.; BORGES, M. Criacionismo. Disponível em:

<http://www.adventistas.org/pt/educacao/projeto/criacionismo/>. Acesso em: 28 ago. 2015.

LESTINGE, S.; SORRENTINO, M. As contribuições a partir do olhar atento: estudos do meio e a educação para a vida. Ciência \& Educação (Bauru), v. 14, n. 3, p. 601-619, 2008.

LOPES, R. J. Congresso reúne adversários da teoria da evolução. Folha de São Paulo, 2014.

MAFRA, C. O que os homens e as mulheres podem fazer com números que fazem coisas. In: TEIXEIRA, F.; MENEZES, R. (Eds.). . Religiões em Movimento: O Censo de 2010. Petrópolis: Vozes, 2013. p. 37-47.

MALAFAIA, S. Criação x Evolução: quem está com a verdade? Rio de Janeiro: Editora Central Gospel, 2009.

MARIANO, R. Neopentecostais : sociologia do novo pentecostalismo no Brasil. São paulo: Loyola, 1999.

MARIANO, R. Análise sociológica do crescimento pentecostal no Brasil. [s.1.] Universidade de São Paulo, 2001.

MAYR, E. The Growth of Biological Thought: Diversity, Evolution, and Inheritance. [s.l: s.n.]. v. 1

MAYR, E. O que é a evolução. Rio de Janeiro: Rocco, 2009.

MCLAREN, P. Multiculturalismo crítico. São Paulo: Cortez, 1997.

MENDONÇA, A. G. Um panorama do protestantismo brasileiro atual. Cadernos do ISER, n. 22, p. 37-86, 1989.

MENDONÇA, A. G. Evangélicos e pentecostais: um campo religioso em ebulição. In: TEIXEIRA, F.; MENEZES, R. (Eds.). . As Religiões no Brasil: Continuidades e rupturas. Petrópolis: Vozes, 2006. p. 89-110.

MEYER, D.; EL-HANI, C. N. Evolução: o sentido da biologia. São paulo: Unesp, 2005.

MIGNOLO, W. Geopolítica de la sensibilidad y del conocimiento | eipcp.net. Disponível em: <http://eipcp.net/transversal/0112/mignolo/es>. Acesso em: 14 jan. 2013.

MOREIRA-ALMEIDA, A. et al. Versão em português da Escala de Religiosidade da Duke - DUREL. Revista de Psiquiatria Clinica, v. 35, n. 1, p. 31-32, 2008. 
NASA. Foundations of Big Bang Cosmology. Disponível em:

<http://map.gsfc.nasa.gov/universe/bb_concepts.html>. Acesso em: 26 ago. 2015.

NUMBERS, R. L. The creationists : from scientific creationism to intelligent design. Cambridge, Mass: Harvard University Press, 2006.

OLEQUES, L. C.; BARTHOLOMEI, M. L.; BOER, S. N. Evolução biológica : percepções de professores de biologia. v. 10, p. 243-263, 2011.

OLIVEIRA, M. C. A. DE. Aspectos da pesquisa acadêmica brasileira sobre o ensino dos temas origem da vida e evolução biológica. [s.l.] Universidade Federal de Santa Catarina, Florianópolis, 2011.

OLIVEIRA, G. DA S.; BIZZO, N. Aceitação da evolução biológica: atitudes de estudantes do ensino médio de duas regiões brasileiras. Revista Brasileira de Pesquisa em Educação em Ciências, v. 11, n. 1, p. 57-79, 2011.

PADIAN, K.; MATZKE, N. Darwin , Dover , “Intelligent Design ” and textbooks. v. 42, p. 29-42, 2009.

PAPA JOÃO PAULO II. Message to the Pontifical Academy of Sciences: On Evolution. Disponível em:

<http://www.ewtn.com/library/papaldoc/jp961022.htm>. Acesso em: 18 fev. 2016.

PETERSON, M. et al. Reason and religious belief: an introduction to the philosophy of religion. New York: Oxford University Press, 2013.

PIERUCCI, A. F. “Bye bye, Brasil": o declínio das religiões tradicionais no Censo 2000. Estudos Avançados, v. 18, n. 52, p. 17-28, 2004.

PIERUCCI, A. F. Cadê nossa diversidade religiosa? Comentários ao texto de Marcelo Camurça. In: TEIXEIRA, F.; MENEZES, R. (Eds.). . As Religiões no Brasil: Continuidades e rupturas. Petrópolis: Vozes, 2006. p. 49-51.

PIERUCCI, A. F. O crescimento da liberdade religiosa e declínio da religião tradicional: a propósito do Censo de 2010. In: TEIXEIRA, F.; MENEZES, R. (Eds.). . Religiões em movimento: o censo de 2010. Petrópolis: Vozes, 2013. p. 49-61.

PRITCHARD, D. What is this thing called knowledge? Routledge T, p. 198, 2006.

REISS, M. J. Studies in Science Education Should science educators deal with the science / religion issue? [s.l: s.n.].

REISS, M. J. The relationship between evolutionary biology and religion.

Evolution, v. 63, n. 7, p. 1934-1941, 2009.

RIBEIRO, C. A. C. Desigualdade de oportunidades educacionais no Brasil: raça, classe e gênero. DADOS - Revista de Ciências Sociais, v. 54, n. 1, p. 41-87, 2011 . 
RUTLEDGE, M. L.; MITCHELL, M. A. High School Biology Teachers'

Knowledge Structure, Acceptance \& Teaching of Evolution. v. 64, n. 1, p. 21-28, 2002.

RUTLEDGE, M. L.; WARDEN, M. A. The Development and Validation of the Measure of Acceptance of the Theory of Evolution Instrument. School Science and Mathematics, v. 99, n. 1, p. 13-18, 1999.

RUTLEDGE, M. L.; WARDEN, M. A. Evolutionary Theory, the Nature of Science \& High School Biology Teachers : Critical Relationships. v. 62, n. 1, p. 23-31, 2000.

SANDERS, M.; NGXOLA, N. Addressing teachers' concerns about teaching evolution. Journal of Biological Education, v. 43, n. 3, p. 121-128, 2009.

SANTOS, S. Evolução biológica: ensino e aprendizagem no cotidiano de sala de aula. São Paulo: Annablume, 2002.

SCOTT, E. C. Evolution vs. creationism : an introduction. Westport, Conn.: Greenwood Press, 2009.

\section{SEEDUC. Caderno de Atividades Pedagógicas de Aprendizagem}

Autorregulada - 01Rio de JaneiroSEEDUC, , [s.d.].

SEEDUC. Currículo Mínimo 2012: Ciências e Biologia. Rio de Janeiro:

Governo do Estado do Rio de Janeiro, 2012a.

SEEDUC. Saerjinho: Matriz de Referência 2012Rio de JaneiroSEEDUC, , $2012 b$.

SEPE. Sepe convoca paralisação nos dias do Saerj. Disponível em: $<$ http://www.seperj.org.br/ver_noticia.php?cod_noticia=3172>. Acesso em: 10 abr. 2015a.

SEPE. A culpa pelo fracasso escolar: Por que não aplicar o SAERJ?

Disponível em: <http://www.seperj.org.br/admin/fotos/boletim/boletim141.pdf>. Acesso em: 10 abr. 2015 b.

SHACKELFORD, J. Myth 7: That Giordano Bruno was the first martyr of modern science. In: Galileo goes to jail and other myths about science and religion. Cambridge, Massachussetts: Harvard University Press, 2009.

SME. Sanção da lei do Ensino Religioso nas escolas da rede. Disponível em: $<$ http://www.rio.rj.gov.br/web/sme/exibeconteudo?article-id=2226122>. Acesso em: 10 abr. 2015.

SMITH, M. U. Current Status of Research in Teaching and Learning Evolution : I . Philosophical / Epistemological Issues. p. 523-538, 2010a.

SMITH, M. U. Current Status of Research in Teaching and Learning Evolution : II . Pedagogical Issues. [s.l: s.n.]. 
SMITH, M. U.; SIEGEL, H. Knowing, Believing, and Understanding: What Goals for Science Education? Science \& Education, v. 13, n. 6, p. 553-582, 2004.

SMITH, M. U.; SIEGEL, H.; MCINERNEY, J. Foundational issues in evolution education. Science \& Education, v. 4, n. 1, p. 23-46, 1995.

SOARES, J. F. O Efeito da escola no Desempenho Cognitivo de seus Alunos. REICE - Revista Electrónica Iberoamericana sobre Calidad, Eficácia y Cambio en Educación, v. 2, n. 2, p. 83-104, 2004.

SOUTHERLAND, S. A. Epistemic Universalism and The Shortcomings of Curricular Multicultural Science Education. Science \& Education, v. 9, n. 3, p. 289-307, 2000.

TEIXEIRA, P. "Eu acredito que Deus esteja por trás da evolução": criacionismo e evolução na concepção de professores de biologia. [s.1.] Pontifícia Universidade Católica do Rio de Janeiro, 2012.

TEIXEIRA, P.; ANDRADE, M. Entre as crenças pessoais e a formação acadêmica: como professores de biologia que professam fé religiosa ensinam evolução? Ciência \& Educação (Bauru), v. 20, n. 2, p. 297-313, 2014.

THAGARD, P.; FINDLAY, S. Getting to Darwin: Obstacles to Accepting Evolution by Natural Selection. Science \& Education, v. 19, n. 6-8, p. 625-636, 2010 .

TIDON, R.; LEWONTIN, R. C. Teaching evolutionary biology. p. 1-8, 2004.

TRANI, R. I won't teach evolution; It's against my religion. And now for the rest of the story.... The American Biology Teacher, v. 66, n. 6, p. 419-427, 2004.

TURA, M. DE L. Observação do Cotidiano Escolar. In: ZAGO, N. (Ed.). . Itinerários de pesquisa: perspectivas qualitativas em sociologia da educação. Rio de Janeiro: DP\&A/Lamparina, 2003. p. 184-205.

WAGLER, A.; WAGLER, R. Addressing the Lack of Measurement Invariance for the Measure of Acceptance of the Theory of Evolution. International Journal of Science Education, v. 35, n. 13, p. 2278-2298, 2013.

WALSH, C. Interculturalidad y (de)colonialidad: Perspectivas críticas y políticasXII Congresso ARIC. Anais...Florianópolis: 2009

YOUNG, M. Grand Designs and Facile Analogies: Exposing Behe's Mousetrap and Dembski's Arrow. In: YOUNG, M.; EDIS, T. (Eds.). . Why Intelligent Design Fails. Piscataway, NJ: Rutgers University Press, 2004. p. 20-31.

ZAGO, N. A entrevista e seu processo de construção: reflexões com base na experiência prática de pesquisa. In: ZAGO, N. (Ed.). . Itinerários de pesquisa: perspectivas qualitativas em sociologia da educação. Rio de Janeiro: DP\&A/Lamparina, 2003. 


\title{
Anexos e apêndices
}

\section{Apêndice 1 - Questionário aplicado aos estudantes ${ }^{67}$}

\author{
PUC-Rio | Departamento de Educação
}

Leia as afirmações abaixo. Marque 1 para aquelas nas quais você NÃO ACREDITA e 5 para aquelas nas quais você ACREDITA FORTEMENTE.

\begin{tabular}{|c|c|c|c|c|c|}
\hline & 1 & 2 & 3 & 4 & 5 \\
\hline 1. Os organismos atuais são resultado de processos evolutivos que ocorreram ao longo de milhões de anos & & & & & \\
\hline 2. Os organismos atuais têm basicamente as mesmas formas que sempre tiveram. & & & & & \\
\hline 3. A teoria da evolução não é capaz de ser testada cientificamente. & & & & & \\
\hline 4. A evolução é uma teoria cientificamente válida. & & & & & \\
\hline 5. Há muitos dados que apoiam a teoria da evolução. & & & & & \\
\hline 6. Os humanos atuais são resultado de processos evolutivos que ocorreram ao longo de milhões de anos. & & & & & \\
\hline 7. Os humanos têm as mesmas formas que sempre tiveram. & & & & & \\
\hline 8. A Bíblia oferece a melhor explicação sobre as características e comportamentos dos seres vivos. & & & & & \\
\hline $\begin{array}{l}\text { 9. A teoria da evolução oferece a melhor explicação sobre as características e comportamentos dos seres } \\
\text { vivos. }\end{array}$ & & & & & \\
\hline 10. Com poucas exceções, os seres vivos surgiram mais ou menos ao mesmo tempo. & & & & & \\
\hline 11. A teoria da evolução não pode estar correta, pois é diferente do que a Bíblia diz sobre a criação. & & & & & \\
\hline 12. O planeta Terra tem pelo menos 4 bilhões de anos. & & & & & \\
\hline
\end{tabular}

Nas questões a seguir assinale a alternativa que você acha correta. Marque apenas uma alternativa para cada questão.

\section{A teoria evolutiva proposta por Charles Darwin pode ser definida como:}

Mudança em populações através do tempo como resultado de mutações.

$\square$ A geração espontânea de novos organismos.

$\square$ A passagem dos genes de uma geração para a seguinte.

$\square$ Mudança em populações ao longo do tempo como resposta a mudanças ambientais.

$\square$ Os organismos desenvolvem características de acordo com suas necessidades.

14. A asa de um morcego e a pata de um cachorro são considerados órgãos homólogos. Isso indica que:

Eles têm a mesma função.

Morcegos evoluíram de uma linhagem de cachorros.

$\square$ Elas são estruturas similares devido a um ancestral comum.

$\square$ o osso do membro de cada um é anatomicamente idêntico.

$\square$ Eles têm ancestralidade diferente, mas uma função comum.
15. Qual das seguintes frases melhor descreve o processo evolutivo?

$\square$ o desenvolvimento dos seres humanos a partir de ancestrais macacos.

$\square$ A mudança de organismos simples para complexos.

$\square$ O desenvolvimento de características em resposta à necessidade.

$\square$ Mudanças populacionais ao longo do tempo.

$\square$ A mudança de populações somente em resposta à seleção natural.

16. Mamíferos marinhos possuem características estruturais em comum com peixes. A explicação da teoria evolutiva para essa semelhança é:

$\square$ Peixes e mamíferos são parentes próximos.

$\square$ Peixes evoluíram estruturas similares àquelas já existentes em mamíferos.

$\square$ Mamíferos marinhos evoluíram diretamente dos peixes.

$\square$ Mamíferos marinhos nunca desenvolveram o uso dos membros.

$\square$ Mamíferos marinhos adaptaram-se a um ambiente similar ao dos peixes.

$67 \mathrm{O}$ questionário foi inserido aqui em escala menor do que o original para respeitar as normas de formatação da universidade e evitar possíveis cortes no processo de impressão. A versão disponibilizada para os estudantes permitia a leitura confortável dos comandos. 
17. Uma mudança no DNA que pode resultar em uma mudança estrutural ou fisiológica no organismo, é chamada de:

$\square$ Deriva gênica.

Fluxo gênico.

Mutação.

Seleção natural.

Gene recessivo.

18. Os primeiros animais a ocuparem o ambiente terrestre provavelmente:

Eram ágeis para escapar de predadores.

Dependiam parcialmente da água para sua sobrevivência.

$\square$ Eram capazes de se adaptar completamente ao ambiente terrestre durante seu tempo de vida.

Possuíam asas para voar de um habitat para outro. $\square$ Alimentavam-se apenas de plantas terrestres
especificas.

\section{Uma mudança climática drástica} provavelmente resultaria, no início, em:

Um rápido aumento da radiação adaptativa.

Um rápido aumento das taxas de extinção.

$\square$ Um grande aumento do número de espécies.

$\square$ Um aumento nas taxas de mutação.

Plantas e animais desenvolveriam novas características para lidar com as mudanças ambientais.

20. A evidência mais convincente para mudanças evolutivas de larga escala (macroevolução) é/são:

$\square \mathrm{O}$ experimento com as mariposas de Manchester.

Os fósseis.

Extinções em massa.

A domesticação de plantas e animais.

O aumento das mutações em todas as espécies.
21. Indivíduos de uma mesma espécie tendem a ser diferentes geneticamente. $O$ principal mecanismo que gera essa variabilidade é:

Meiose.

Mitose.

Poliploidia.

Duplicação.

Reprodução assexuada.

22. Os fósseis mais antigos já encontrados são de:

Fungos.

Bactérias.

Pequenas plantas.

Plantas com sementes.

Protozoários.

23. Qual das afirmações representa melhor as ideias evolutivas de Lamarck?

A sobrevivência dos mais adaptados.

Herança de características adquiridas.

Deriva neutra.

Equilíbrio pontuado.

Acasalamento seletivo.

24. Qual das afirmações $\underline{N A ̃ O}$ é parte da teoria da seleção natural de Darwin?

Indivíduos de uma população variam.

Seres vivos tendem a se reproduzir ao máximo.

Os indivíduos competem por recursos limitados.

As modificações que um organismo adquire durante sua vida podem ser passadas para seus descendentes.

Algumas variações apresentadas pelos indivíduos de uma população são herdáveis. 
Leia as afirmações abaixo. Marque 1 para aquelas com as quais você NÃO CONCORDA e 5 para aquelas com as quais você CONCORDA TOTALMENTE.

25. Em minha vida, eu sinto a presença divina.

26. As minhas crenças religiosas são muito importantes para toda a minha maneira de viver.

27. Eu me esforço muito para seguir os preceitos da minha religião em todos os aspectos da vida.

28. Com que frequência você vai a uma igreja, templo ou outro encontro religioso? (Marque apenas uma alternativa)

$\square$ Mais do que uma vez por semana.

$\square$ Uma vez por semana.

Duas ou mais vezes por mês.

Algumas vezes por ano.

Uma vez por ano ou menos.

$\square$ Nunca.

29. Com que frequência você realiza atividades religiosas individuais, como preces, rezas, meditações, leitura da Bíblia ou de outros textos religiosos? (Marque apenas uma alternativa):

Mais do que uma vez ao dia.

Uma vez ao dia.

Duas ou mais vezes por semana

Uma vez por semana

Uma vez por mês ou menos.

$\square$ Nunca.

30. Quanto à sua religião, você é:

Acredito em Deus, mas não tenho religião.

$\square$ Ateu.

$\square$ Candomblecista.

Católico.

Espírita Kardecista.

$\square$ Evangélico.

Testemunha de Jeová.

Umbandista.

Outro. Qual?
31. Qual o nome completo da igreja/ templo /terreiro/centro/paróquia que você frequenta?

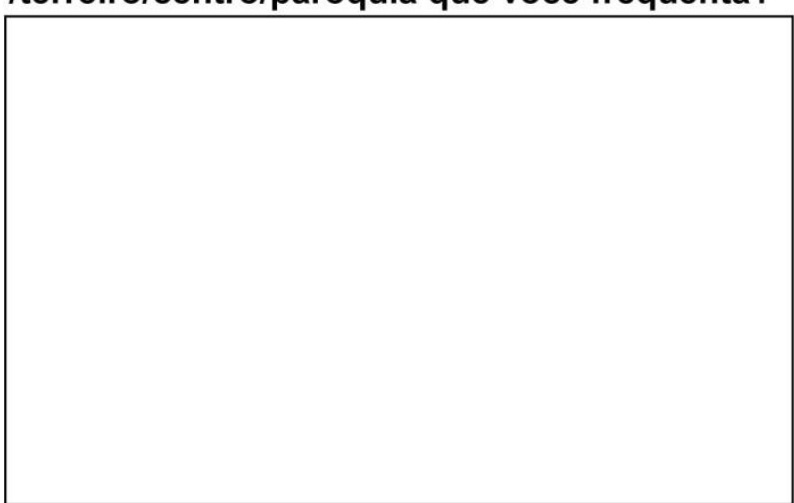

Não frequento nenhuma igreja/ templo/ terreiro/centro/paróquia.(vá para a questão 34)

32. Você participa de algum grupo ou realiza alguma função em sua igreja/ templo/ terreiro/ centrol paróquia?

Não participo de nenhum grupo/função.

Sim. Qual(is)?

33. Você frequenta cultos/reuniões de outras religiões?

$\square$ Não frequento cultos/reuniões de outras religiões.

Sim. Qual(is)? 
34. Qual a cidade em que você mora?

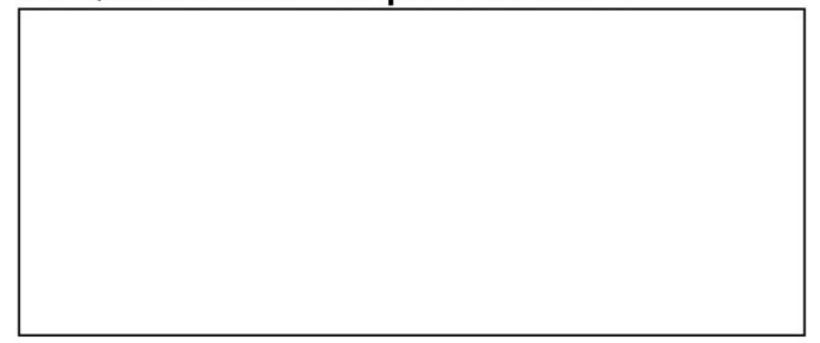

35. Qual o bairro em que você mora?

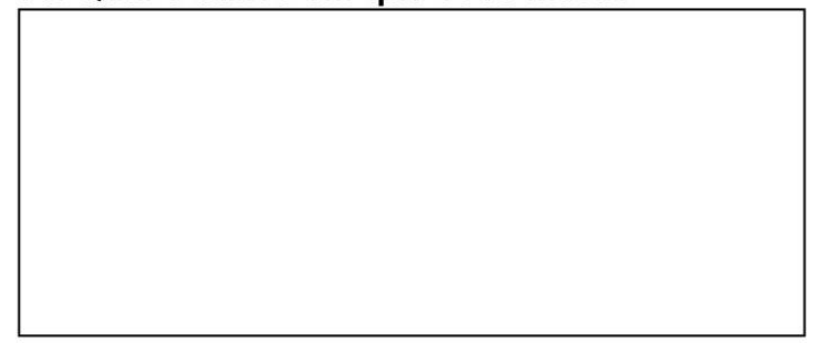

36. Qual o seu sexo?

$\square$ Masculino $\square$ Feminino

37. Qual a sua data de nascimento?

(DIA) $\frac{1}{(\mathrm{MENS})} \frac{1}{(\mathrm{ANO})}$

38. Como você se considera?

$\square$ Branco(a) $\square$ Pardo(a)

$\square$ Preto(a) $\square$ Amarelo(a) $\square$ Indígena

39. Na sua casa tem televisão em cores?

$\square$ Sim, uma.

$\square$ Sim, duas.

$\square$ Sim, três ou mais.

Não tem.

40. Na sua casa tem rádio?

$\square$ Sim, um.

$\square$ Sim, dois.

Sim, três ou mais.

Não tem.

41. Na sua casa tem videocassete ou DVD?

$\square$ Sim.

Não.

\section{Na sua casa tem geladeira?}

$\square$ Sim, uma. $\quad \square$ Sim, duas ou mais.

Não tem.

43. Na sua casa tem freezer junto a geladeira?

$\square$ Sim.

Não. $\square$ Não sei.
44. Na sua casa tem freezer separado da geladeira?

$\square$ Sim

Não.

Não sei.

45. Na sua casa tem uma máquina de lavar roupa? (Não é tanquinho).

$\square$ Sim.

$\square$ Não.

\section{Na sua casa tem carro?}

Sim, um.

Sim, dois.

Sim, três ou mais.

Não tem.

47. Na sua casa tem um computador?

$\square$ sim, com internet. $\square$ sim, sem internet.

Não.

48. Dentro de sua casa tem banheiro?

$\square$ Sim, um. $\square$ Sim, dois. $\square$ Sim, três.

$\square$ Sim, mais de três. $\square$ Não.

49. Na sua casa trabalha alguma empregada doméstica?

Sim, uma diarista, uma ou duas vezes por semana.

Sim, uma, todos os dias úteis.

Sim, duas ou mais, todos os dias úteis.

$\square$ Não.

50. Na sua casa tem quartos para dormir?

$\square$ Sim, um. $\square$ Sim, dois. $\square$ Sim, três.

$\square$ Sim, quatro ou mais. $\square$ Não.

51. Quantas pessoas moram com você?

$\square$ Moro sozinho(a) ou com mais 1 pessoa.

Moro com mais 2 pessoas.

Moro com mais 3 pessoas.

Moro com mais 4 ou 5 pessoas.

Moro com mais 6 a 8 pessoas.

Moro com mais do que 8 pessoas.

52. Você mora com sua mãe?

Sim.

$\square$ Não (passe para a questão 56)

Não. Moro com outra

mulher responsável por mim. 
53. Até que série sua mãe ou a mulher responsável por você estudou?

$\square$ Nunca estudou ou não completou o $5^{\circ}$ ano (antigo primário).

$\square$ Completou o $5^{\circ}$ ano, mas não completou o $9^{\circ}$ ano (antigo ginásio).

$\square$ Completou o $9^{\circ}$ ano, mas não completou o Ensino Médio (antigo $2^{\circ}$ grau).

Completou o Ensino Médio, mas não completou a Faculdade.

Completou a Faculdade.

Não sei.

54. Sua mãe ou a mulher responsável por você sabe ler e escrever?
Sim.
Não.
Não sei.

55. Você vê sua mãe ou a mulher responsável por você lendo?
$\square$ Sim.
Não.

56. Você mora com seu pai?

Sim.

Não (passe para a questão 60)

Não. Moro com outro homem responsável por mim.

57. Até que série seu pai ou o homem responsável por você estudou?

$\square$ Nunca estudou ou não completou o $5^{\circ}$ ano (antigo primário)

$\square$ Completou o $5^{\circ}$ ano, mas não completou o $9^{\circ}$ ano (antigo ginásio).

Completou o $9^{\circ}$ ano, mas não completou o Ensino Médio (antigo $2^{\circ}$ grau).

$\square$ Completou o Ensino Médio, mas não completou a Faculdade.

Completou a Faculdade.

Não sei.

58. Seu pai ou o homem responsável por você sabe ler e escrever?

Sim.

Não.

Não sei.

59. Você vê o seu pai ou o homem responsável por você lendo?

$\square \operatorname{Sim}$.

Não.
60. Seus pais ou responsáveis incentivam você $a$ ir à escola e não faltar às aulas?

Sim.

Não.

61. Seus pais ou responsáveis conversam com você sobre o que acontece na escola?

Sim.

Não.

62. Você trabalha fora de casa?

Sim. $\square$ Não.

63. Desde o $6^{\circ}$ ano do ensino fundamental, em que tipo de escola você estudou?

Somente escola pública.

Somente em escola particular.

Em escola pública e em escola particular.

64. Você gosta de estudar biologia?

Sim.

Não.

65. Você faz o dever de casa de biologia?

Sempre ou quase sempre.

De vez em quando.

Nunca ou quase nunca.

O professor não passa dever de casa.

66. O professor corrige o dever de casa de biologia?

Sempre ou quase sempre.

De vez em quando.

Nunca ou quase nunca.

O que você consulta para fazer o dever de casa de biologia? (marque sim ou não para cada um das opções).

\begin{tabular}{|l|l|l|}
\cline { 2 - 3 } \multicolumn{1}{l|}{} & Sim & Não \\
\hline 67. Jornais. & & \\
\hline 68. Revistas de informação geral. & & \\
\hline 69. Livros didáticos. & & \\
\hline 70. Livros ou enciclopédias. & & \\
\hline 71. Sites da internet. & & \\
\hline
\end{tabular}

72. Quando você terminar o ensino médio, você pretende:

Somente continuar estudando.

Somente trabalhar.

Continuar estudando e trabalhar.

Ainda não sei. 


\section{Apêndice 2 - Roteiro de entrevista dos professores}

\section{I - Experiência profissional}

1. Fale um pouco sobre a sua experiência profissional. Quando e como você começou a trabalhar como professor? E nesta escola?

2. Por que você pensou em ser professor de biologia? Para você, quais as principais características de um professor de biologia?

\section{II - Religião}

3. Fale um pouco sobre a sua crença religiosa. Tem religião? Já teve? Quando e como você começou sua fé religiosa?

4. Com que frequência você participa de cultos? Que valor você atribuiria à religião na sua vida?

\section{III - Evolução}

5. O que lhe vem mais forte à cabeça quando você pensa em evolução?

6. Como você define evolução biológica?

7. Você possui alguma explicação pessoal para a evolução biológica?

8. Você ensina evolução? Por quê? Como? Que materiais utiliza?

\section{IV - Criacionismo}

9. O que lhe vem mais forte à cabeça quando você pensa em criacionismo?

10. Como você define criacionismo?

11. Você possui alguma explicação pessoal para o criacionismo?

12. Você ensina criacionismo? Por quê? Como? Que materiais utiliza?

\section{V - Relação evolução x criacionismo}

13. Você já teve alguma dificuldade em conciliar sua fé e crença religiosa e os estudos em biologia?

14. Se sim, essas dificuldades aparecem em suas aulas? Como você resolve isso?

15. Você conhece algum professor de biologia que já teve alguma dificuldade envolvendo fé e ciência? Você já teve alguma dificuldade? Poderia relatar algo? 
VI - Livro Didático

16. O que acha do livro didático adotado pela escola esse ano? Por quê?

17. Como foi o processo de escolha na escola? Concordou com a decisão? Por quê? Escolheria outro? Qual? E sobre a distribuição?

18. Todos os alunos receberam o livro? Por quê? O que fazer para equacionar o problema da distribuição?

19. Utiliza o livro didático? De que maneira? Por quê?

\section{VII - Currículo Mínimo e Saerjinho}

20. O que acha do currículo mínimo do estado? Por quê?

21. Como foi formulado? Como se sente nesse processo?

22. Faria modificações? Quais?

23. O que acha do Saerjinho? Por quê?

24. Como foi formulado? Como se sente nesse processo? 


\section{Apêndice 3 - Roteiro de entrevista dos estudantes}

1. Você acredita em Deus?

2. Qual a sua religião?

3. Com que frequência você vai à missa/cultos?

4. Qual a importância da sua igreja para você?

5. Você frequenta algum grupo da sua religião? Qual? Exerce alguma atividade em sua religião? Se sim, qual?

6. Seus pais/responsáveis são religiosos? Qual a religião deles? Eles estimulam que você participe da religião deles? Se você não participa, qual a reação deles?

7. Você vai às aulas de religião da escola? Por quê?

8. Como você explicaria a origem da vida no planeta?

9. Como você acha que o ser humano surgiu no planeta?

10. Como se sente quando o professor fala que a vida pode ter surgido por processos naturais, sem a ação de Deus?

11. Você já se sentiu discriminado na escola por causa de sua religião? 


\section{Apêndice 4 - Perfil profissional dos professores}

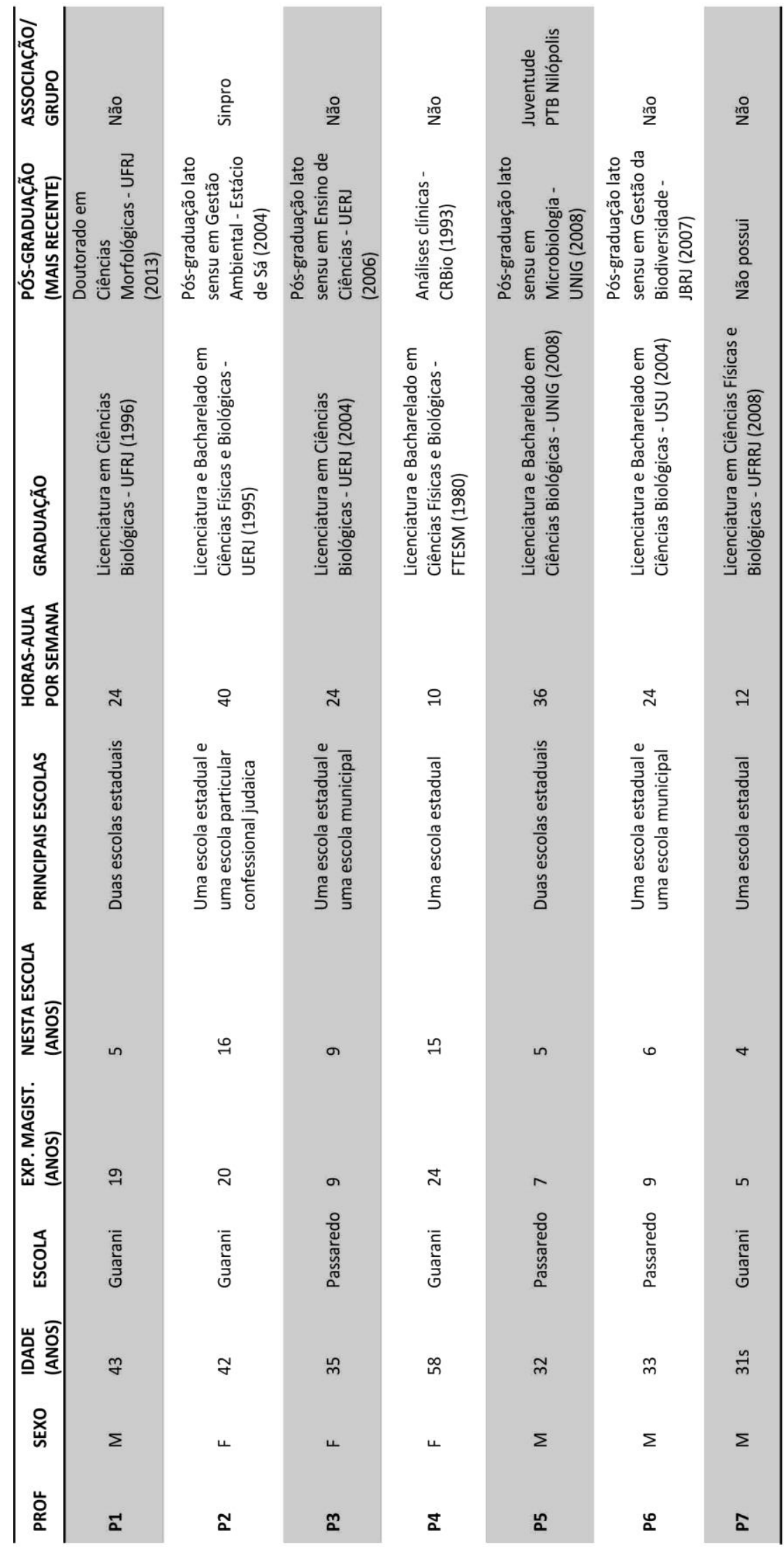




\section{Apêndice 5 - Perfil religioso dos professores}

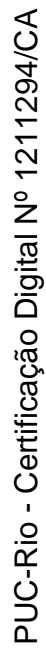

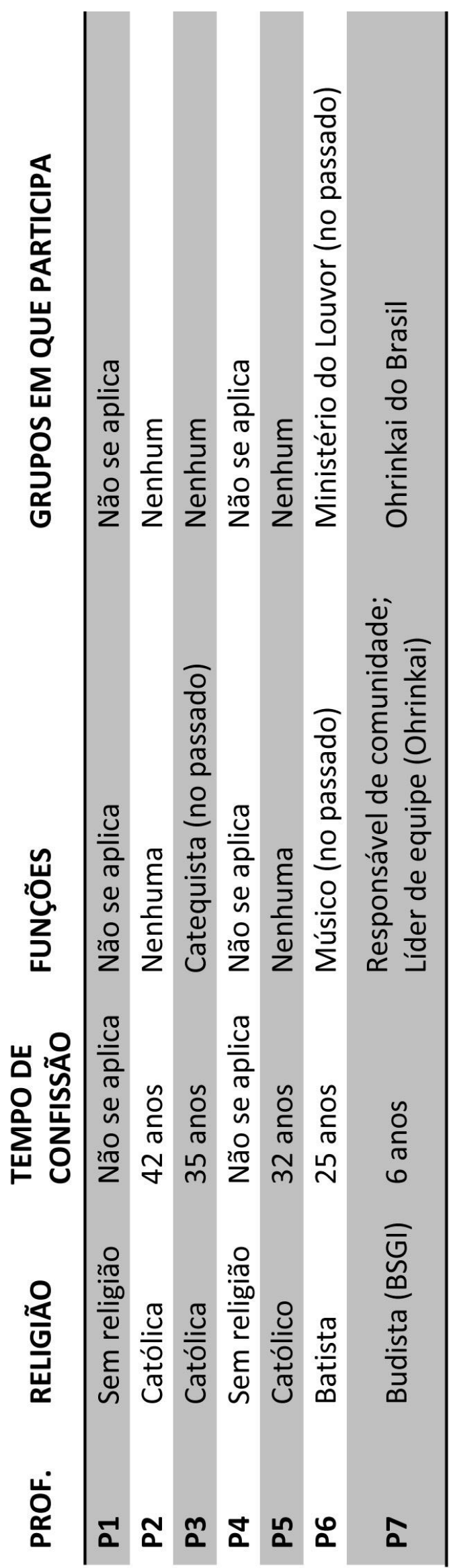




\section{Apêndice 6 - Perfil dos estudantes entrevistados}

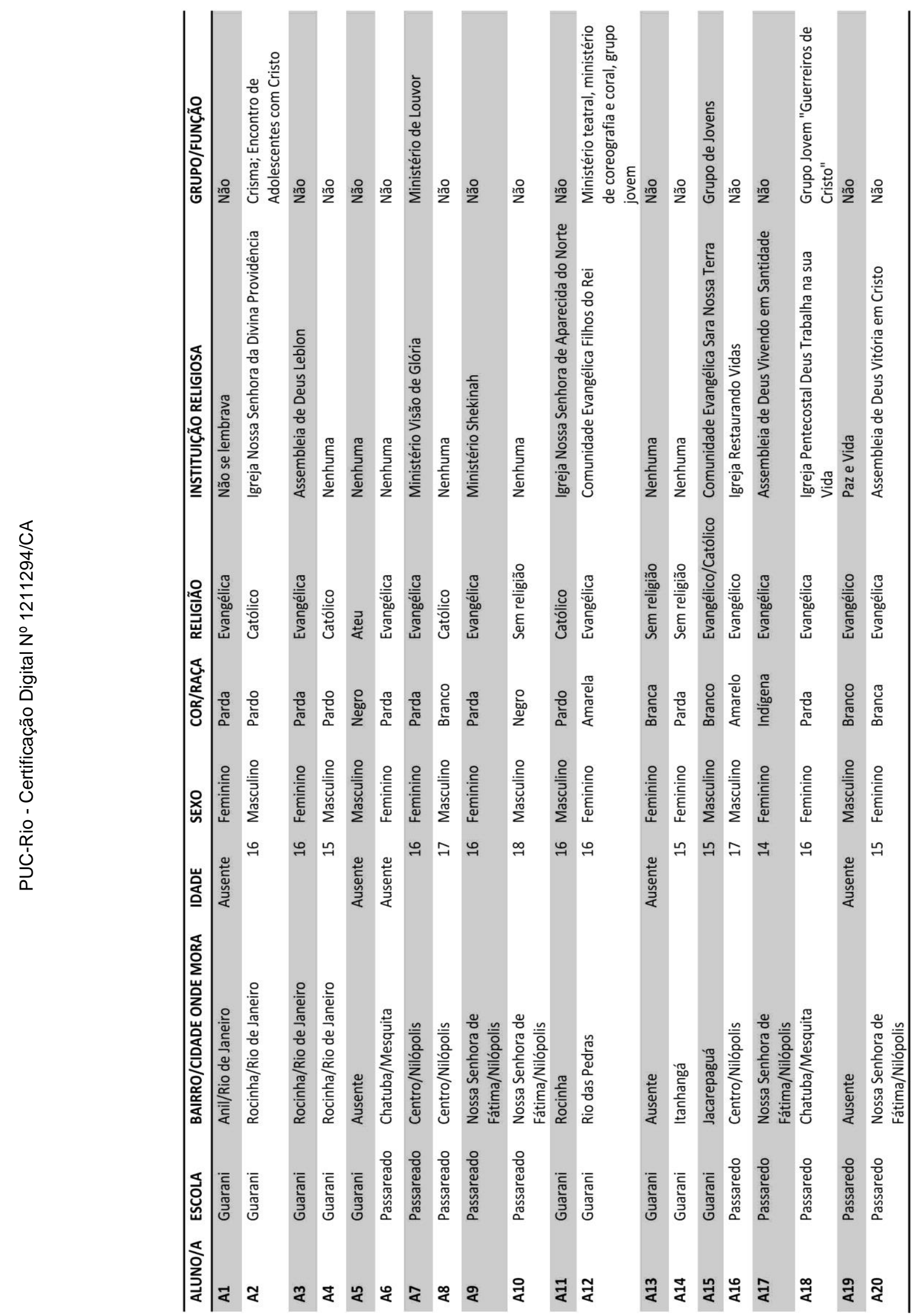




\section{Apêndice 7 - Ficha de identificação para os professores}

\begin{tabular}{|c|c|c|}
\hline \multicolumn{3}{|c|}{$\begin{array}{l}\text { Prática Pedagógica e Ética Intercultural } \\
\qquad \text { FORMULÁRIO DE IDENTIFICAÇÃO }\end{array}$} \\
\hline Nome: & & \\
\hline Idade: & & \\
\hline Tempo de magistério: & & \\
\hline Tempo de atuação no $1^{\circ}$ ano do ensino médio: & & \\
\hline Em quantas escolas você trabalha atualmente: & & \\
\hline $\begin{array}{l}\text { Ao todos, quantas horas-aula você ministra por } \\
\text { semana? (Não considere aulas particulares): }\end{array}$ & & \\
\hline
\end{tabular}

\section{Escolas em que atua (indique as duas principais):}

\begin{tabular}{|l|l|}
\hline Tipo (pública ${ }^{1}$, privada $^{2}$ ): & \\
\hline Anos/Séries que atua: & \\
\hline Há quanto tempo atua nessa escola: & \\
\hline
\end{tabular}

\begin{tabular}{|l|l|}
\hline Tipo (pública, privada): & \\
\hline Anos/Séries que atua: & \\
\hline Há quanto tempo atua nessa escola: & \\
\hline
\end{tabular}

\section{Formação | Graduação}

\begin{tabular}{|l|l|}
\hline Curso: & \\
\hline Instituição: & \\
\hline Ano de término & \\
\hline
\end{tabular}

$\square$ Apenas licenciatura $\square$ Apenas bacharelado $\square$ Licenciatura e bacharelado

${ }^{1}$ Se for uma escola pública, por favor, indique se é municipal, estadual ou federal.

${ }^{2}$ Se for uma escola privada, por favor, indique se é confessional, se faz parte de uma rede de ensino ou outra informação que considere relevante. 
Formação | Pós-Graduação (indique no máximo duas)

\begin{tabular}{|l|l|}
\hline Curso: & \\
\hline Instituição: & \\
\hline Ano de término & \\
\hline
\end{tabular}

\begin{tabular}{|l|l|}
\hline Curso: & \\
\hline Instituição: & \\
\hline Ano de término: & \\
\hline
\end{tabular}

\section{Religião}

\begin{tabular}{|l|l|}
\hline Denominação: & \\
\hline Tempo de confissão: & \\
\hline $\begin{array}{l}\text { Funções que exerce: } \\
\text { (Indique até duas) }\end{array}$ & 1 - \\
\cline { 2 - 2 } & $2-$ \\
\hline $\begin{array}{l}\text { Grupos que participa: } \\
\text { (Indique até dois) }\end{array}$ & $1-$ \\
\cline { 2 - 2 } & $2-$ \\
\hline
\end{tabular}

\section{Outras Atividades}

Você participa de algum outro grupo (partido, sindicato, ONG, grupo cultural, grupo de estudo)? Se sim, quais?

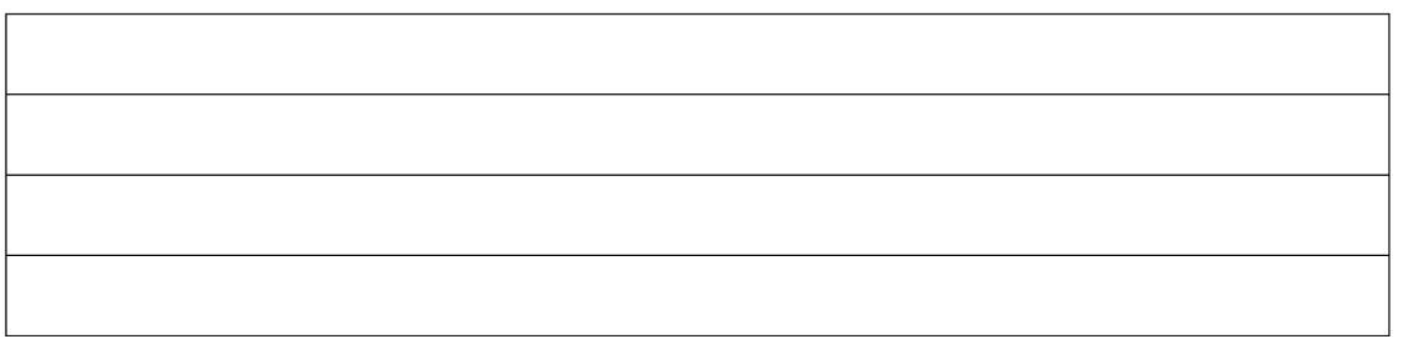

Quantos dos alunos das suas turmas do $1^{\circ}$ ano do ensino médio nesta escola você acha que (Marque apenas UMA opção para cada linha):

\begin{tabular}{|l|c|c|c|c|c|}
\hline & $\begin{array}{c}\text { Quase todos } \\
\text { os alunos }\end{array}$ & $\begin{array}{c}\text { Um pouco } \\
\text { mais da } \\
\text { metade dos } \\
\text { alunos. }\end{array}$ & $\begin{array}{c}\text { Um pouco } \\
\text { menos da } \\
\text { metade dos } \\
\text { alunos. }\end{array}$ & $\begin{array}{c}\text { Poucos } \\
\text { alunos. }\end{array}$ & Não sei. \\
\hline concluirão o ensino médio? & (A) & (B) & (C) & (D) & (E) \\
\hline entrarão para a universidade? & (A) & (B) & (C) & (D) & (E) \\
\hline
\end{tabular}




\section{Apêndice 8 - Variáveis utilizadas para as correlações}

\begin{tabular}{|c|c|c|}
\hline Variável & Tipo & Descrição \\
\hline $\begin{array}{l}\text { Fator Aceitação } \\
\text { Aspectos Científicos da } \\
\text { Evolução }\end{array}$ & Contínua & $\begin{array}{l}\text { Índice construído utilizando as questões } 1,4,5,6 \text { e } 12 \text {. } \\
\text { Quanto maior este valor, mais o estudante aceita os } \\
\text { aspectos científicos da teoria evolutiva neodarwinista. }\end{array}$ \\
\hline $\begin{array}{l}\text { Fator Aceitação da } \\
\text { Narrativa Bíblica (NB) }\end{array}$ & Contínua & $\begin{array}{l}\text { Índice construído utilizando as questões } 8 \text { e } 11 \text {. Quanto } \\
\text { maior este valor, mais o estudante aceita a narrativa } \\
\text { Bíblica para a origem dos seres vivos. }\end{array}$ \\
\hline $\begin{array}{l}\text { Entendimento da } \\
\text { Evolução (E. Evo.) }\end{array}$ & Contínua & $\begin{array}{l}\text { Índice construído utilizando as questões } 13 \text { a } 24 \text {. } \\
\text { Quanto maior este valor, maior o entendimento da } \\
\text { teoria evolutiva neodarwinista. }\end{array}$ \\
\hline $\begin{array}{l}\text { Religiosidade Intrínseca } \\
\text { (RI) }\end{array}$ & Contínua & $\begin{array}{l}\text { Índice construído utilizando as questões 25, 26, } 27 . \\
\text { Quanto maior este valor, maior a religiosidade } \\
\text { intrínseca do estudante. }\end{array}$ \\
\hline $\begin{array}{l}\text { Religiosidade } \\
\text { Organizacional (RO) }\end{array}$ & Contínua & $\begin{array}{l}\text { Índice construído utilizando as questões } 28 \text {. Quanto } \\
\text { maior este valor, maior a religiosidade organizacional } \\
\text { do estudante. }\end{array}$ \\
\hline $\begin{array}{l}\text { Religiosidade Não } \\
\text { Organizacional (RNO) }\end{array}$ & Contínua & $\begin{array}{l}\text { Índice construído utilizando as questões 29. Quanto } \\
\text { maior este valor, maior a religiosidade não } \\
\text { organizacional do estudante. }\end{array}$ \\
\hline $\begin{array}{l}\text { Acredito em Deus, mas } \\
\text { não tenho religião } \\
\text { (ADNR) }\end{array}$ & Dicotômica & $\begin{array}{l}1=\text { Estudante acredita em Deus, mas não tem religião } \\
0=\text { Pertence a outra religião. }\end{array}$ \\
\hline Ateu & Dicotômica & 1 = Estudante é ateu; 0 = Estudante não é ateu. \\
\hline Católico (Catól.) & Dicotômica & 1= Estudante é católico; 0 = Estudante não é católico. \\
\hline Evangélico & Dicotômica & $\begin{array}{l}1 \text { = Estudante é evangélico; } 0 \text { = Estudante não é } \\
\text { evangélico. }\end{array}$ \\
\hline Outro & Dicotômica & $\begin{array}{l}\text { Estudante pertence a outros grupos religiosos }=1 \\
\text { Estudante não pertence a outros grupos religiosos }=0 .\end{array}$ \\
\hline 16 anos & Dicotômica & $\begin{array}{l}0=\text { Estudante tem } 17 \text { anos ou mais; } \\
1=\text { Estudante tem } 16 \text { anos ou menos. }\end{array}$ \\
\hline Sexo & Dicotômica & $0=$ Masculino; 1 = Feminino \\
\hline Branco & Dicotômica & 0 = Não branco; 1 = Branco . \\
\hline Pardo & Dicotômica & $0=$ Não pardo; 1 = Pardo. \\
\hline Negro & Dicotômica & 0 = Não negro; 1 = Negro. \\
\hline $\begin{array}{l}\text { Escolaridade máxima } \\
\text { dos responsáveis }\end{array}$ & Dicotômica & $\begin{array}{l}0 \text { = Nenhum dos responsáveis têm ensino médio } \\
\text { completo } \\
1 \text { = Pelo menos um dos responsáveis têm ensino médio } \\
\text { completo. }\end{array}$ \\
\hline $\begin{array}{l}\text { Gosta de estudar } \\
\text { biologia }\end{array}$ & Dicotômica & $0=$ Não; 1 = Sim. \\
\hline $\begin{array}{l}\text { Faz dever de casa de } \\
\text { biologia }\end{array}$ & Dicotômica & $\begin{array}{l}\text { Variável adaptada a partir da questão } 65 . \\
0=\text { Nunca ou quase nunca; O professor não passa } \\
\text { dever de casa; } \\
1 \text { = Sempre ou quase sempre; De vez em quando. }\end{array}$ \\
\hline $\begin{array}{l}\text { Prof. corrige o dever de } \\
\text { biologia }\end{array}$ & Dicotômica & $\begin{array}{l}\text { Variável adaptada a partir da questão } 66 . \\
0=\text { Nunca ou quase nunca; } \\
1 \text { = Sempre ou quase sempre; De vez em quando. }\end{array}$ \\
\hline
\end{tabular}




\section{Apêndice 9 - Lista de temas e códigos}

Abaixo são listados os principais temas (em negrito) e códigos (referentes a cada tema) utilizados na análise dos dados qualitativos, juntamente com suas descrições.

TEMA/CÓDIGO

DESCRIÇÃO

\begin{tabular}{|c|c|}
\hline $\begin{array}{l}\text { Conflitos em sala de aula - } \\
\text { Professores }\end{array}$ & $\begin{array}{l}\text { Tema que abrange experiências de conflitos ou } \\
\text { sua ausência em sala de aula, com relação à } \\
\text { origem e evolução da vida. }\end{array}$ \\
\hline Já teve conflito em sala & $\begin{array}{l}\text { Se o(a) professora já passou por conflito com } \\
\text { estudantes por causa da origem e evolução da } \\
\text { vida. }\end{array}$ \\
\hline Tipo de conflito & $\begin{array}{l}\text { Se o conflito foi desenvolvido, na opinião do(a) } \\
\text { professor(a), com uma forte discussão ou não. }\end{array}$ \\
\hline Razões para haver conflito & $\begin{array}{l}\text { As razões argumentadas pelo(a) professor(a) } \\
\text { para que existam conflitos em sala de aula. }\end{array}$ \\
\hline Razões para não haver conflito & $\begin{array}{l}\text { As razões argumentadas pelo(a) professor(a) } \\
\text { para que não existam conflitos em sala de aula. }\end{array}$ \\
\hline Descrição do conflito & $\begin{array}{l}\text { A descrição, nas palavras do(a) professor(a), da } \\
\text { situação de conflito vivida em sala de aula. }\end{array}$ \\
\hline $\begin{array}{l}\text { Estratégias para lidar com o } \\
\text { conflito }\end{array}$ & $\begin{array}{l}\text { Estratégias apontadas pelo(a) professor(a) para } \\
\text { lidar com o conflito em sala de aula. Podem ser } \\
\text { maneiras de inibi-lo, evitá-lo ou responder aos } \\
\text { questionamentos feitos pelos estudantes. }\end{array}$ \\
\hline
\end{tabular}

\begin{tabular}{|c|l|}
\hline $\begin{array}{l}\text { Posicionamento pessoal com } \\
\text { relação à evolução e ao } \\
\text { criacionismo - Professores }\end{array}$ & $\begin{array}{l}\text { Tema que abrange as concepções pessoais } \\
\text { dos(as) professores(as) sobre as relações entre } \\
\text { ciência e religião, evolução e criacionismo. }\end{array}$ \\
\hline Concilia evolução e criacionismo & $\begin{array}{l}\text { Se o(a) professor(a) possui ou não concepções } \\
\text { que buscam conciliar evolução e criacionismo. }\end{array}$ \\
\hline Já teve conflito pessoal (interno) & $\begin{array}{l}\text { Se o(a) professor(a) já teve ou não algum tipo } \\
\text { de conflito pessoal (interno) entre suas crenças } \\
\text { religiosas e os conhecimentos de biologia. }\end{array}$ \\
\hline $\begin{array}{l}\text { O uso de evidências científicas } \\
\text { para sustentar a concepção de } \\
\text { criacionismo }\end{array}$ & $\begin{array}{l}\text { Se o(a) professor(a) usa ou não evidências } \\
\text { científicas para justificar crenças criacionistas. }\end{array}$ \\
\hline Leitura da Bíblia & $\begin{array}{l}\text { Se o(a) professor(a) faz uma leitura literal ou } \\
\text { não do livro bíblico do Gênesis. }\end{array}$ \\
\hline Evolucionismo teísta & $\begin{array}{l}\text { Se o(a) professor(a) adota ou não o } \\
\text { evolucionismo teísta, isto é, se Deus ou uma } \\
\text { Força guia a evolução. }\end{array}$ \\
\hline
\end{tabular}




\begin{tabular}{|l|l|}
\hline Deus ou força & $\begin{array}{l}\text { Se o(a) professor(a) se refere à entidade } \\
\text { transcendental em que acredita como "Deus" ou } \\
\text { como "Força". }\end{array}$ \\
\hline Criacionismo de dia-era & $\begin{array}{l}\text { Se o(a) professor(a) faz referência à ideia de } \\
\text { que os dias da criação do Gênesis não são } \\
\text { intervalos de } 24 \text { horas, mas sim eras. }\end{array}$ \\
\hline Criacionismo de intervalo & $\begin{array}{l}\text { Se o(a) professor(a) faz referência à ideia que } \\
\text { pode ter ocorrido um momento de criação divina } \\
\text { posterior a grandes mudanças evolutivas. }\end{array}$ \\
\hline $\begin{array}{l}\text { Flexibilização do conceito de } \\
\text { teoria }\end{array}$ & $\begin{array}{l}\text { Se o(a) professor(a) utiliza o conceito de } \\
\text { evolução de forma flexível, de modo a } \\
\text { considerar o criacionismo como uma teoria } \\
\text { válida. }\end{array}$ \\
\hline Evolução espiritual & $\begin{array}{l}\text { Se o(a) professor(a) considera que haja uma } \\
\text { diferença de evolução de espíritos entre } \\
\text { diferentes seres vivos. }\end{array}$ \\
\hline
\end{tabular}

\begin{tabular}{|c|c|}
\hline $\begin{array}{l}\text { Evolução, origem da vida e } \\
\text { evolução humana - Estudantes }\end{array}$ & $\begin{array}{l}\text { Tema que abrange as concepções pessoais } \\
\text { dos(as) estudantes sobre a evolução, origem da } \\
\text { vida e evolução humana. }\end{array}$ \\
\hline $\begin{array}{l}\text { Deus atua/atuou diretamente na } \\
\text { evolução/origem dos humanos }\end{array}$ & $\begin{array}{l}\text { Estudante acredita que Deus atua ou atuou } \\
\text { diretamente na criação ou nos processos } \\
\text { evolutivos que formaram os seres humanos. }\end{array}$ \\
\hline Acredita em Adão e Eva & Estudante acredita na existência de Adão e Eva. \\
\hline $\begin{array}{l}\text { Ser humano surgiu a partir de } \\
\text { processos evolutivos }\end{array}$ & $\begin{array}{l}\text { Estudante afirma que os seres humanos } \\
\text { surgiram a partir de processos evolutivos } \\
\text { naturais. }\end{array}$ \\
\hline Ser humano não veio do macaco & $\begin{array}{l}\text { Estudante não acredita que ser humano tenha } \\
\text { surgido de macacos. }\end{array}$ \\
\hline $\begin{array}{l}\text { Ser humano pode ter surgido } \\
\text { através da ação de ETs }\end{array}$ & $\begin{array}{l}\text { Estudante acredita que extraterrestres podem } \\
\text { ter atuado no surgimento dos seres humanos. }\end{array}$ \\
\hline Aceita o Big Bang & Estudante aceita o Big Bang. \\
\hline Concepção de Big Bang & $\begin{array}{l}\text { Descrição pessoal do estudante sobre o Big } \\
\text { Bang. }\end{array}$ \\
\hline Origem da Terra & $\begin{array}{l}\text { Descrição pessoal do estudante sobre a origem } \\
\text { do planeta Terra. }\end{array}$ \\
\hline
\end{tabular}




\begin{tabular}{|c|l|}
\hline $\begin{array}{l}\text { Relação entre ciência e religião - } \\
\text { Estudantes }\end{array}$ & $\begin{array}{l}\text { Tema que abrange as relações entre religião e } \\
\text { ciência para os estudantes entrevistados. }\end{array}$ \\
\hline Tenta conciliar ciência e religião & $\begin{array}{l}\text { Estudante tentar conciliar os conhecimentos de } \\
\text { ciência e religião. }\end{array}$ \\
\hline Religião e ciência são rivais & $\begin{array}{l}\text { Estudante acredita que ciência e religião são } \\
\text { opostas. }\end{array}$ \\
\hline Cientistas são ateus & Estudante acredita que os cientistas são ateus. \\
\hline $\begin{array}{l}\text { Cientistas são confiáveis porque } \\
\text { estudaram muito }\end{array}$ & $\begin{array}{l}\text { Estudante acredita que os cientistas são } \\
\text { confiáveis porque se dedicaram muito a estudar } \\
\text { um tema. }\end{array}$ \\
\hline Cientistas são diabólicos & $\begin{array}{l}\text { Estudante acredita que os cientistas são } \\
\text { diabólicos. }\end{array}$ \\
\hline
\end{tabular}

\begin{tabular}{|c|c|}
\hline $\begin{array}{l}\text { Aulas de evolução e origem da } \\
\text { vida - Estudantes }\end{array}$ & $\begin{array}{l}\text { Tema que abrange as concepções dos } \\
\text { estudantes sobre as aulas que assistiram sobre } \\
\text { evolução e origem da vida. }\end{array}$ \\
\hline $\begin{array}{l}\text { Professor tem medo de discutir } \\
\text { religião }\end{array}$ & $\begin{array}{l}\text { Estudante acredita que o(a) professor(a) não se } \\
\text { aprofunda muito nesses temas porque tem } \\
\text { medo de discutir religião. }\end{array}$ \\
\hline $\begin{array}{l}\text { Já teve conflito com o que } \\
\text { estava sendo ensinado }\end{array}$ & $\begin{array}{l}\text { Estudante já teve conflito com o que foi } \\
\text { ensinado sobre evolução e origem da vida. }\end{array}$ \\
\hline $\begin{array}{l}\text { Manifestou sua opinião para o } \\
\text { professor }\end{array}$ & $\begin{array}{l}\text { Estudante manifestou ou não sua discordância } \\
\text { para o professor. }\end{array}$ \\
\hline $\begin{array}{l}\text { Acha que as aulas influenciam } \\
\text { suas crenças }\end{array}$ & $\begin{array}{l}\text { Estudante acredita que as aulas influenciam } \\
\text { suas crenças religiosas. }\end{array}$ \\
\hline $\begin{array}{l}\text { Acha que suas crenças } \\
\text { influenciam a maneira como vê } \\
\text { as aulas }\end{array}$ & $\begin{array}{l}\text { Estudante acredita que suas crenças religiosas } \\
\text { influenciam a maneira como vê os conteúdos } \\
\text { ensinados pelo(a) professor(a). }\end{array}$ \\
\hline
\end{tabular}




\section{Anexo 1 - Currículo Mínimo de Biologia para o 1ªno do ensino} médio

\section{Biologia}

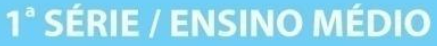

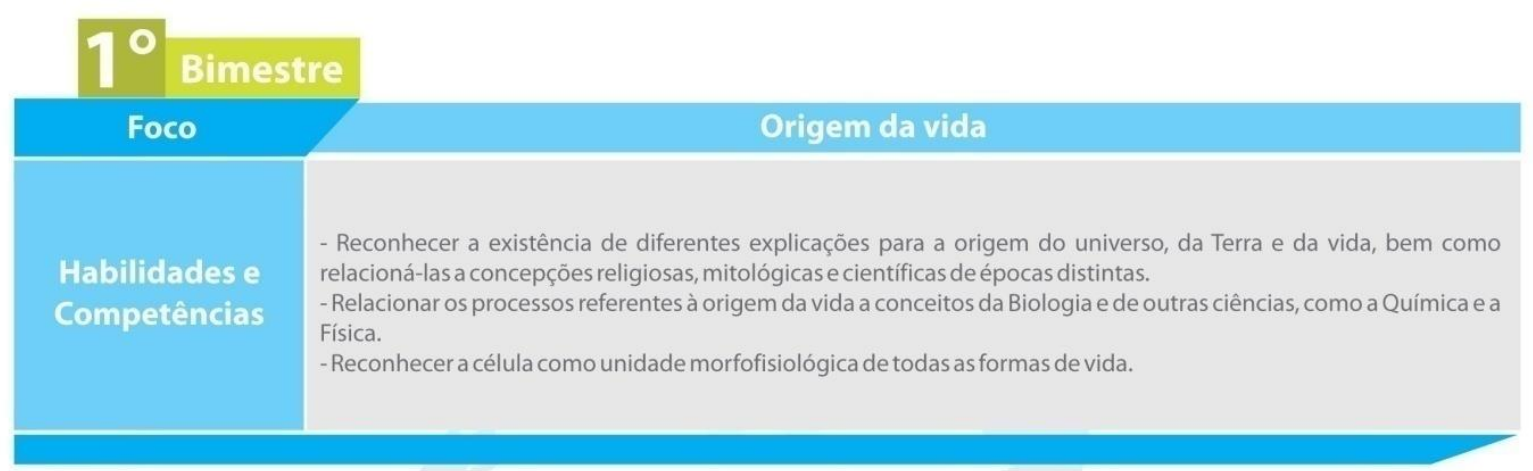

- Identificar os mecanismos de transmissão da vida, reconhecendo a relação entre reprodução sexuada, hereditariedade, identidade e diversidade dos seres vivos.

Habilidades e

- Associar a reprodução celular à transformação do zigoto em adulto e ao desenvolvimento de processos patológicos.

Competências

- Relacionar síntese de proteínas à ação dos genes, identificando, de modo geral, como ocorre a regulação da expressãogênica.

- Correlacionar genética, evolução e manutenção da vida na Terra.

Reconhecer a importância da evolução na promoção de modelos, processos biológicos e organização da taxonomia dos seres vivos.

-Identificar, filogeneticamente, as relações de parentesco entre os seres vivos.

- Reconhecer a diversidade de seres vivos no planeta, relacionando suas características aos seus modos de vida eaos seus limites de distribuição em diferentes ambientes, principalmente os brasileiros. 
Anexo 2 - Matriz do Saerjinho para Biologia do $1^{\circ}$ ano do ensino médio

\section{SAERJINHO \\ MATRIZ DE REFERÊNCIA}

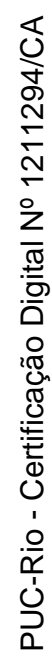

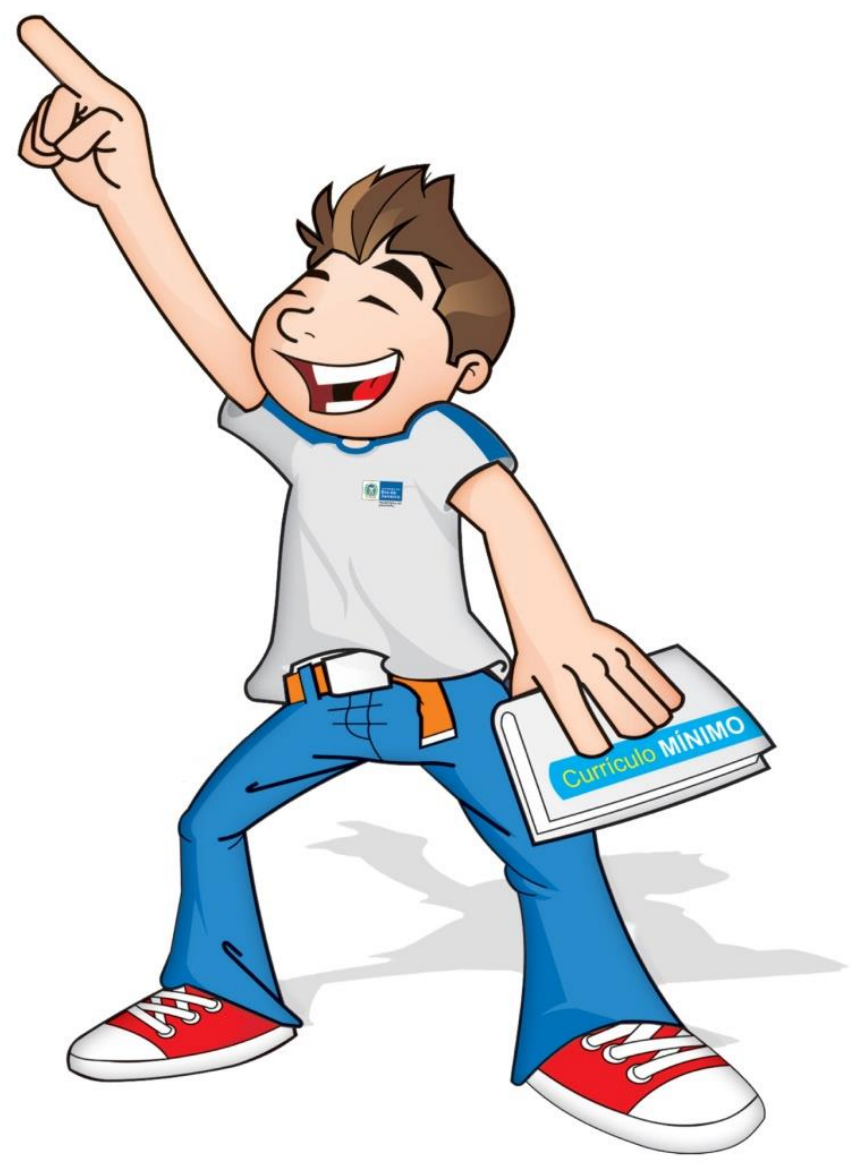




\section{MATRIZ DE REFERÊNCIA DE BIOLOGIA - SAERJINHO 2012} $1^{\circ}$ ANO ENSINO MÉDIO

\begin{tabular}{|c|c|c|c|c|c|}
\hline Domínio & & Habilidade & B1 & B2 & B3 \\
\hline \multirow{2}{*}{ MATÉRIA E ENERGIA } & H01 & $\begin{array}{l}\text { Identificar a transformação de energia luminosa em química através } \\
\text { da fotossíntese. }\end{array}$ & $\mathrm{x}$ & & \\
\hline & HO2 & $\begin{array}{l}\text { Identificar diferentes fontes de produção de energia: hidráulica, eólica, } \\
\text { solar, nuclear, geotérmica, de biomassa e fóssil. }\end{array}$ & $x$ & & \\
\hline \multirow{11}{*}{$\begin{array}{l}\text { TERRA E } \\
\text { UNIVERSO }\end{array}$} & H04 & $\begin{array}{l}\text { Identificar diferentes explicações sobre as transformações do } \\
\text { ambiente terrestre que possibilitaram a origem dos seres vivos. }\end{array}$ & $x$ & & \\
\hline & H05 & Identificar concepções sobre a origem da vida. & $x$ & & \\
\hline & H06 & $\begin{array}{l}\text { Interpretar experiências e argumentos utilizados por cientistas como } \\
\text { Redi e Pasteur para derrubar a teoria da geração espontânea. }\end{array}$ & $x$ & & \\
\hline & H07 & $\begin{array}{l}\text { Diferenciar irradiação de convergência adaptativa, relacionando-os à } \\
\text { compreensão da dispersão da vida na Terra. }\end{array}$ & & & $x$ \\
\hline & H09 & $\begin{array}{l}\text { Reconhecer a história da vida na Terra com base em escala temporal: } \\
\text { o surgimento da vida, das plantas, dos animais e do homem. }\end{array}$ & $x$ & & \\
\hline & H10 & $\begin{array}{l}\text { Identificar as semelhanças e diferenças entre as diversas teorias } \\
\text { evolucionistas. }\end{array}$ & & & $x$ \\
\hline & H11 & Reconhecer os fatores que determinam o processo de especiação. & & & $x$ \\
\hline & H12 & $\begin{array}{l}\text { Reconhecer as mutações e a seleção como fontes da diversidade de } \\
\text { espécies em um determinado ambiente. }\end{array}$ & & & $x$ \\
\hline & H13 & $\begin{array}{l}\text { Reconhecer que as transformações das espécies ao longo do tempo } \\
\text { são resultantes dos mecanismos de mutação, recombinação gênica } \\
\text { e seleção natural. }\end{array}$ & & & $x$ \\
\hline & H14 & $\begin{array}{l}\text { Identificar o efeito estufa como condição necessária à existência da } \\
\text { vida no planeta. }\end{array}$ & $x$ & & \\
\hline & H15 & $\begin{array}{l}\text { Associar a produção de oxigênio molecular com a formação da camada } \\
\text { de ozônio, indispensáveis para a existência e evolução da vida na Terra. }\end{array}$ & $x$ & & \\
\hline \multirow{9}{*}{$\begin{array}{r}\text { VIDAE } \\
\text { AMBIENTE }\end{array}$} & $\mathrm{H} 2 \mathrm{O}$ & $\begin{array}{l}\text { Reconhecer a teoria científica que explicita a origem e evolução das } \\
\text { células. }\end{array}$ & $x$ & & \\
\hline & H21 & $\begin{array}{l}\text { Reconhecer o papel da seleção natural no processo evolutivo dos } \\
\text { seres vivos. }\end{array}$ & & & $x$ \\
\hline & $\mathrm{H} 22$ & $\begin{array}{l}\text { Reconhecer a célula como sendo a unidade morfofisiológica dos } \\
\text { seres vivos. }\end{array}$ & & $x$ & \\
\hline & $\mathrm{H} 23$ & Associar as etapas do processo de síntese proteica à expressão gênica. & & $x$ & \\
\hline & $\mathrm{H} 24$ & $\begin{array}{l}\text { Reconhecer os processos de divisão celular, a partir de representações } \\
\text { e esquemas. }\end{array}$ & & $x$ & \\
\hline & H25 & $\begin{array}{l}\text { Identificar as principais etapas do desenvolvimento embrionário, } \\
\text { enfatizando o papel das células totipotentes. }\end{array}$ & & $x$ & \\
\hline & $\mathrm{H} 26$ & $\begin{array}{l}\text { Identificar, em representações esquemáticas, os processos de } \\
\text { formação dos gametas. }\end{array}$ & & $x$ & \\
\hline & H27 & $\begin{array}{l}\text { Reconhecer a reprodução sexuada como promotora da diversidade } \\
\text { de seres vivos. }\end{array}$ & & $x$ & \\
\hline & $\mathrm{H} 28$ & $\begin{array}{l}\text { Diferenciar a reprodução sexuada da assexuada quanto ao gasto energético, } \\
\text { quantidade de individuos gerados, complexidade e rapidez de ocorrência. }\end{array}$ & & $x$ & \\
\hline \multirow{4}{*}{$\begin{array}{l}\text { SER HUMANO } \\
\text { E SAÚDE }\end{array}$} & H29 & $\begin{array}{l}\text { Reconhecer que as divisões mitóticas descontroladas podem resultar } \\
\text { em processos patológicos. }\end{array}$ & & $x$ & \\
\hline & $\mathrm{H} 30$ & $\begin{array}{l}\text { Reconhecer as teorias explicativas para origem, evolução e dispersão } \\
\text { da espécie humana. }\end{array}$ & & & $x$ \\
\hline & H31 & $\begin{array}{l}\text { Identificar o código genético como responsável pelo conjunto de } \\
\text { características do indivíduo. }\end{array}$ & & $x$ & \\
\hline & H32 & $\begin{array}{l}\text { Reconhecer que alterações funcionais no código genético promovem } \\
\text { modificações adaptativas das espécies podendo ocasionar ou não a evolução. }\end{array}$ & & & $x$ \\
\hline
\end{tabular}




\section{Anexo 3 - A história de Napi}

\section{Napi, os homens e os animais \\ Heloisa Prieto}

No início do mundo nasceu o Sol, e depois dele surgiu Napi, o criador, o guardião da vida. Um dia, Napi descansava perto de uma fonte. Olhou para a terra úmida e teve uma ideia: pensou que seria divertido moldar pequenas criaturas de argila. Primeiro modelou um animalzinho. Gostou dele e continuou a criar. Fez aparecer todos os animais que até hoje vivem na face da terra. Quando terminou deu a cada animal um lugar para habitar. Por último moldou o homem e lhe disse:

- Você deve viver na floresta, é o melhor lugar para você.

Depois, fechou os olhos e tentou descansar. Mas não conseguiu. Poucas horas mais tarde, os animais voltaram para reclamar. Ninguém estava feliz. O touro parecia furioso:

- Não posso viver na montanha, Napi. Preciso de pasto!

O antílope também estava aborrecido:

- Napi, não posso viver no pântano, meu sonho, correr pelos campos!

Até mesmo o sensato camelo tinha uma queixa:

- Napi, detestei o deserto! Será que você não pode me mudar de lugar?

O homem, então, não parava de reclamar. Queria viver viajando, queria conhecer todos os lugares.

Era muito curioso para ficar só na floresta. Napi suspirou e respondeu:

- Minhas queridas criaturas, vou lhes dar outros territórios! Calma! E depois disse:

- Touro, vá para os pastos! - E para o antílope: - Vá para a savana correr com liberdade. - E, finalmente, para o camelo: - Vá para perto de um oásis, onde o ar é fresco.

E quando chegou o homem, Napi lhe sugeriu diversos lugares para morar, mas o homem nunca ficava contente. Até que o guardião da vida se cansou e disse apenas:

- Você é mesmo impossível, meu filho! Tudo bem, vá para onde quiser!

É por isso que todos os animais têm seus territórios preferidos, mas o homem, essa criatura sempre insatisfeita, espalhou-se pelas montanhas, florestas, rios e mares, e até hoje continua procurando novos lugares para morar.

(PRIETO, H. História da Mitologia Africana: Lá vem história. São Paulo, Companhia das Letrinhas, 1997) 